UNIVERSIDADE DE SÃO PAULO

MUSEU DE ARQUEOLOGIA E ETNOLOGIA

PROGRAMA DE PÓS-GRADUAÇÃO EM ARQUEOLOGIA

MILENA ACHA

Um estudo etnoarqueológico sobre o pastoreio em Santa María, Argentina

São Paulo

2016 
Versão revisada

A versão original encontra-se na biblioteca do MAE 


\section{Um estudo etnoarqueológico sobre o pastoreio em Santa María, Argentina}

Tese apresentada ao Programa de PósGraduação em Arqueologia do Museu de Arqueologia e Etnologia da Universidade de São Paulo para obtenção do título de Doutor em Arqueologia

Área de Concentração:

Arqueologia

Orientadora: Prof ${ }^{a}$. Dr ${ }^{\mathrm{a}}$. Fabíola Andrea Silva

Linha de Pesquisa: Espaço, sociedade e Processos de Formação do registro Arqueológico

Durante o desenvolvimento deste trabalho o autor recebeu auxílio financeiro da CAPES 

Aos meus pais. 


\section{Resumo}

Acha, M. Um estudo etnoarqueológico sobre o pastoreio em Santa María, Argentina. Tese (Doutorado), Museu de Arqueologia e Etnologia, Universidade de São Paulo, São Paulo, 2016 .

A presente tese se centra na compreensão do sistema pastoril em Santa María, Província de Catamarca, Argentina. Os grupos pastoris desta região apresentam mobilidade sazonal em busca de fontes hídricas e pastagens, indicando movimentos que tradicionalmente se distinguem entre os vales e o interior das serras. Especificamente, esta mobilidade que lhes é característica também atua na percepção e apreensão da paisagem. Neste contexto, a paisagem tem um valor ativo nestas práticas e no imaginário das pessoas do lugar. A partir de uma abordagem etnoarqueológica se buscará compreender a maneira como as características específicas do sistema pastoril atuam na relação entre humanos e o meio e na internalização da paisagem, considerando as implicações materiais dessas escolhas e comportamentos.

Palavras-chave: Pastoreio, Mobilidade, Paisagem, Noroeste Argentino, Etnoarqueologia. 


\section{Abstract}

Acha, M. Um estudo etnoarqueológico sobre o pastoreio em Santa María, Argentina. Tese (Doutorado), Museu de Arqueologia e Etnologia, Universidade de São Paulo, São Paulo, 2016.

This dissertation focuses on understanding the pastoral system in Santa María, Catamarca province, Argentina. Pastoralists movements are based on a seasonal mobility to search water sources and pastures, indicating movements that are traditionally distinguished between the valleys and the mountains. Specifically, the mobility pattern also acts on perception and apprehension of the landscape. In this context, the landscape has an active value in practices and imagination of the pastoral people. The study uses an ethnoarchaeological approach, to investigate the pastoralist system, and the implications of the relationship between humans and the environment and the internalization of landscape, considering the material implications of choices and behaviors.

Keywords: Pastoralism, Mobility, Landscape, Northwest Argentina, Ethnoarchaeology. 


\section{Agradecimentos}

Primeiramente, gostaria de agradecer aos funcionários, funcionárias e à instituição do Museu de Arqueologia e Etnologia da Universidade de São Paulo, onde pude desenvolver a minha pesquisa. Também, agradeço aos professores e professoras e aos meus colegas pelas diversas contribuições em todos estes longos anos.

À Capes - Coordenação de aperfeiçoamento de pessoal de nível superior - pela bolsa de pesquisa que fomentou este trabalho durante quatro anos.

À minha orientadora, Dr ${ }^{a}$ Fabíola Silva, que esteve sempre presente, orientando e me encorajando, corrigindo os meus escritos com infinita paciência e discutindo sobre os temas diversos que levaram à constituição deste trabalho e à minha própria formação na área da arqueologia.

Ao Dr. Rui Murrieta, com quem aprendi muito em suas orientações informais. Agradeço pelas frutíferas discussões, ideias inovadoras e pelos caminhos apresentados, entre eles o viés mais ecológico da antropologia que permeia todos os âmbitos desta tese.

À equipe do Proyecto Arqueológico Cajón, ao Dr. Javier Nastri, à equipe do Proyecto Arqueológico Yacovil, à Dr ${ }^{\mathrm{a}}$ Myriam Tarragó, por me possibilitarem levantar dados para desenvolver esta pesquisa, e as pessoas que os integram que me permitiram compartilhar diversas experiências do conhecimento arqueológico. Em especial à Violeta Cantarelli, pela amizade de todos estes anos. Ao Néstor Whascham, quem me ajudou com os dados de localização geográfica e persistentemente me acompanhou em diversas caminhadas pela serra do Cajón.

Ao Dr. Terry McCabe, por compartilhar o seu conhecimento comigo de tão bom grado, e ter dados as diretrizes finais para alcançar este resultado. Também, ao Institute of Behavior Science/Colorado University-Boulder, por abrir as suas portas me permitindo participar de um novo universo de trabalho e conversas. Também, aos amigos que foram a minha rede de suporte em Boulder. 
Ao Lintt - Laboratório de Estudos Interdisciplinares sobre Tecnologia e Território - onde eu pude trabalhar e fazer amizades. Agradeço especialmente à Melian e à Lorena, pelas conversas e apoio.

Aos professores membro da banca, Dr. Gustavo Politis, Dr ${ }^{\mathrm{a}}$. Juliana S. Machado, Dr. Paulo DeBlasis e Dr ${ }^{\mathrm{a}}$ Veronica Wesolowski de Aguiar e Santos. Agradeço pelo cuidado e a dedicação para com o trabalho da tese, pelas agradáveis palavras e as instigantes perguntas e questionamentos levantados.

Às pessoas de Santa María, em espacial à Gloria, Angeles, Edith, Tere, Doña Ana, Don Clemente, Don Yampa, Santos, Don Lázaro y Pablito, que me acolheram e me ajudaram em tudo que lhes estava nas mãos. Sou eternamente grata ao empenho que tiveram e ao valor que eles viram nas minhas propostas, sem eles este trabalho não seria possível.

Aos amigos e amigas que foram a minha segunda família: Rafael, Denise e Fernando, Tiago, Erêndira, Débora, Camila (e Ravizinho), Patrick, Silvia Helena, Satiko, Vivi e Franz, Luís, Pedro, Fábio, que souberam me enriquecer com a suas presenças e me entender nas minhas ausências. Também, às minhas amigas de infância de Dolores, por me acolherem por lá.

À minha família gregária, tios e tias, primos e primas, pelo carinho e suporte entre tantas idas e vindas, pelo apoio constante demonstrado em perguntas, questionamentos, recortes de jornal, conversas sobre o mercado de gado, comidas favoritas, livros para se escrever uma tese e muito mais. À minha vó Edith, sempre presente.

Agradeço em especial, aos meus pais e irmão, pelo apoio e pelo amor que sempre me dedicaram, sem os quais não teria conseguido chegar até aqui.

Ao Rafael, que de um jeito ou de outro sempre contribuir para este trabalho, se tem poesia nestes escritos, ela veio de ti. 


\section{Sumário}

\section{Introdução}

1 - Primeiras Questões

2 - De como começou este trabalho 1

3 -Objetivos 3

4 - Sobre o Método, a Etnoarqueologia e a Coleta de Dados 4

4.1 - Sobre o Método e a Etnoarqueologia 4

4.2 - Qual etnoarqueologia se buscou trabalhar 5

4.2.1 - A Etnoarqueologia nos Andes $\quad 8$

4.2.2 - Uma proposta interdisciplinar $\quad 9$

$\begin{array}{ll}4.3 \text { - Sobre a coleta de dados } & 11\end{array}$

5 - Resumo dos Capítulos 16

\section{CAPÍTULO 1 - Chegando a Santa María. Uma introdução}

$\begin{array}{ll}1 \text { - Chegando a Santa María } & 19\end{array}$

$2-$ O Vale de Santa María. Características $\quad 22$

2.1 - Características gerais $\quad 22$

2.2 - Geomorfologia 26

2.3 - Sobre a bacia do rio Santa María 31

2.4 - Clima 38

2.5 - Fauna e Flora 44

2.5.1 - Vales áridos, bolsões e quebradas $\quad 45$

$\begin{array}{ll}2.5 .2 \text { - Puna } & 47\end{array}$

2.6 - Característica humana $\quad 50$

3 - Breve descrição da ocupação do vale de Santa María 50

3.1 - Primeiros momentos $\quad 50$

3.2 - Sobre o período Colonial $\quad 68$

3.3 - Nos últimos anos. Processos de reconhecimento das identidades indígenas $\quad 73$

CAPÍTULO 2 - Os Pastores. Os elementos do sistema pastoril no vale de Santa María

$\begin{array}{ll}1 \text { - Os estudos sobre pastores } & 77\end{array}$ 
2 - De que pastoreio se está falando? Características e classificações

2.1 - Item 1 - Localização geográfica: vale de Santa María 82

2.2 - Item 2 - A ecologia: Ambiente Andino 82

2.3 - Item 3 - As espécies utilizadas

2.4 - Item 4 - Sistema de gerenciamento: Qual tipo de pastoreio? 86

2.4.1 - Conversando com Dom Vicêncio sobre o pastoreio 87

2.4.2 - Guadalupe. Uma mulher pastora 92

3 - Divisão do trabalho 95

4 - Divisão do espaço: o alto das serras e os vales 99

5 - O que é ser pastor? 102

$\begin{array}{ll}5.1 \text { - Sobre a domesticação animal } & 105\end{array}$

5.1.1 - O significado e o possível processo da domesticação 105

5.1.2 - Alguns apontamentos sobre as relações entre animais e humanos nestes vales 109

$\begin{array}{ll}5.2 \text { - Sobre as instituições pastoris tradicionais nestes vales } & 114\end{array}$

\section{CAPÍTULO 3 - Sobre Movimentos e Assentamentos. A mobilidade dos pastores}

$\begin{array}{ll}1-\text { A mobilidade no pastoreio } & 117\end{array}$

$\begin{array}{ll}2 \text { - Mobilidade e suas características } & 119\end{array}$

$\begin{array}{lr}2.1 \text { - A natureza do movimento } & 120\end{array}$

$\begin{array}{ll}2.1 .1 \text { - Mobilidade Residencial } & 120\end{array}$

$\begin{array}{ll}2.1 .2 \text { - Mobilidade Logística } & 122\end{array}$

$\begin{array}{ll}2.1 .3 \text { - Distâncias curtas } & 122\end{array}$

2.1.4 - Distâncias intermediárias 123

2.1.5 - Distâncias longas $\quad 126$

$\begin{array}{ll}2.1 .6 \text { - Troca de produtos e as caravanas } & 127\end{array}$

2.2 - A motivação dos movimentos $\quad 128$

2.2.1 - Definição de transumância. Sobre qual sistema de mobilidade estamos falando? 132

2.2.2 - Características gerais do movimento no vale de Santa María 134

3 - Tipos de Assentamento 139

$\begin{array}{ll}3.1 \text { - Casas na cidade } & 141\end{array}$

$\begin{array}{ll}3.2 \text { - Casa de campo } & 144\end{array}$

$\begin{array}{ll}3.3 \text { - Postos temporários } & 146\end{array}$

CAPÍTULO 4 - Caminhos e Lugares. Uma introdução aos elementos da paisagem pastoril. 
1 - Introdução

2 - A conceptualização da paisagem

2.1 - Conceptualização de espaço, de lugar e de movimento

2.1.1 - Sobre como utilizaram-se os conceitos de espaço e lugar 158

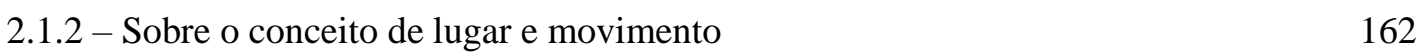

3 - Narrativas de trajetos 163

3.1 - Trajetória e localização: sobre os vetores no espaço 164

$\begin{array}{ll}3.2 \text { - Trajetos e caminhos } & 166\end{array}$

$\begin{array}{ll}3.3 \text { - O caminho de Dom Yucra } & 169\end{array}$

4 - Sobre caminhos e marcadores de caminhos $\quad 178$

$\begin{array}{ll}4.1 \text { - Conhecimento dos caminhos } & 186\end{array}$

$\begin{array}{lr}4.2 \text { - Sobre rotas } & 188\end{array}$

\section{CAPÍTULO 5 - Paisagens Contemporâneas. Uso e representação de sítios nos dias atuais.}

$\begin{array}{ll}1 \text { - Retomando a noção de paisagem } & 191\end{array}$

2 - Percepção e paisagem 196

2.1 - Sobre as áreas $\quad 197$

2.1.1 - Área 1: O sítio arqueológico de Las Mojarras 199

2.1.2 - Área 2: O sítio arqueológico Rincón Chico 209

2.1.3 - Área 3: sítios na área da queda de água da Virgen Perida 217

$\begin{array}{lr}\text { Reflexões Finais } & 225\end{array}$

1 - Sobre as áreas de captação e de maior probabilidade arqueológica 226

2 - Sobre a complexidade da dinâmica do pastoreio 232

3 - Questões da vida moderna que afetam os pastores 234

3.1 - Influências das mudanças 234

3.2 - As mudança e adaptabilidade quanto ao assentamento 237

$\begin{array}{ll}\text { Últimas palavras } & 239\end{array}$

$\begin{array}{ll}\text { Bibliografia } & 242\end{array}$ 


\section{Lista de Figuras}

1. Mapa indicando a área total abarcada pela coleta de informações. 12

2. Mapa indicando a associação de informação de interlocutores. 13

3. Mapa indicando a Formação das Serras Pampeanas no território argentino. 23

4. Mapa indicando a rede hidrográfica das províncias de Jujuy, Salta e Catamarca. 33

5. Mapa indicando a bacia hídrogeológica do rio Santa María. 34

6. Mapa indicando o comportamento das águas na bacia do rio Santa María. 37

7. Mapa mundial da classificação climática de Köppen para o período 1951-2000. 40

8. Gráfico indicando as variações de temperatura de acordo com a altitude ao decorrer do ano em Santa María.

9. Gráfico de temperatura, indicando as variações de temperatura que ocorrem em um ciclo anual.

10. Mapa indicando os tipos e as variedades dos climas na província de Catamarca. $\quad 44$

11. Mapa do Vale de Santa María, Noroeste Argentino. 51

12. Plano de um conjunto de habitações em Tafí del Valle, Tucumán.

13. Representação do centro cerimonial La Rinconada. 58

14. Região do Noroeste Argentino contendo as comunidades arqueológicas. $\quad 60$

15. Mapa representando a expansão do Tawantisuyu. 66

$\begin{array}{ll}\text { 16. Mapa da vista do vale de Santa María atravessado pela estrada Nacional No } 40 . & 67\end{array}$

17. Mapa indicando as diferentes comunidades indígenas e a sua dispersão no território argentino. 76

18. Curral em Santa María. 113

19. Gráfico representando as médias de movimentos pastoris referentes a Santa Maria e

$\begin{array}{lr}\text { El Carmen. } & 126\end{array}$

20. Imagem indicado mapa de Santa María com as direções aproximadas que os pastores seguem.

21. Gráfico de mobilidade pastoril. 138

22. Foto da cidade de Santa María. 140

23. Foto da cidade de Santa María. 140

24. Foto da vista de Las Mojarras. 141

25. Representação de uma casa de cidade. 142

26. Reprodução de uma casa de campo. 145

27. Reprodução de um posto temporário do alto da serra. 147 
28. Gráfico representando os tipos de assentamentos.

30. Imagem ilustrando o mapa com alguns caminhos referente à localidade de

El Carmen.

31. Imagem ilustrando o mapa ilustrando um dos caminhos em destaque.

32. Imagem ilustrativa do mapa com o caminho percorrido com Dom Yucra.

33. Foto do grande curral que hoje já não é mais utilizado.

34. Foto do curral atualmente utilizado.

35. Imagem indicando o primeiro local de parada pelas pedras amontoadas ao fundo, com vista do caminho.

36. Imagem indicando as lascas e pequenos muros de pirca.

37. Imagem indicando o curral no alto da serra, construído com materiais rochosos da redondeza.

38. Imagem indicando os pontos do percurso de Dom Yucra.

39. Representando o trajeto feito com Dom Yucra desde uma vista E-O.

40. Fotos representando 3 tipos de caminhos que podem ser designados como "caminho lindo".

41. Fotos representando os tipos de caminhos das serras.

42. Fotos representando tipos de caminho.

43. Fotos representando marcadores de caminhos.

44. Mapa indicando os trajetos para cruzar o rio Santa María.

45. Imagem indicando o mapa com as áreas destacadas e a presença de alguns sítios arqueológicos associados.

46. Construções na parte alta de Cerro Pintado de Las Mojarras.

47. Imagem da serra que incorpora as construções do Cerro Pintado Las Mojarras.

48. Imagens ilustrando os trajetos.

49. Imagens indicando a presença de cardones por entre as ruínas.

50. Imagem indicando os restos materiais que ainda são evidentes na cima da serra.

51. Imagem indicando o local do passeio associado ao sítio arqueológico de

Las Mojarras.

52. Imagens exemplificando a presença de huancas nos caminhos de Las Mojarras. 209

53. Imagens exemplificando a presença de huancas nos caminhos de Las Mojarras. 209

54. Imagem indicando os sítios identificados do complexo Rincón Chico.

55. Imagem indicando a presença de construções em Rincón Chico indicadas por

Guadalupe.

56. Imagens indicando a presença de símbolos na paisagem.

57. Imagem referenciando as localizações no mapa.

58. Representando o esquema da estrutura do posto no sítio arqueológico Los Pozos 3. 219 
59. Imagem representando a possível reconstrução do sítio arqueológico Los Pozos 3. 219

60. Um dos caminhos em direção à Virgen Perdida. 


\section{Lista de Tabelas}

1. Precipitações mensais na província de Catamarca. 24

2. Temperaturas médias anuais na província de Catamarca. 25

3. As explorações agropecuárias à base de irrigação, na província de Catamarca. $\quad 26$

4. Produto bruto geográfico da província de Catamarca. 26

5. Estratigrafia do vale de Santa Maria. 28

6. Indicativo dos caudais aflorando no pé do médano do rio Santa María. 35

7. Indicativo dos parâmetros básicos da bacia do rio Santa María. 35

8. Tabela climática. 42

9. Tipos de produção divididos por famílias. 131

10. Tipos de assentamentos representando a $1^{a}$ geração. Informação oral coletada. $\quad 149$

11. Tipos de assentamentos representando a $2^{\mathrm{a}}$ geração 150

12. Resumo dos movimentos pastoris. 153

13. Quadro comparativo de modos pastoris atuais. 233 


\section{Introdução}

\section{1 - Primeiras Questões}

Neste trabalho propomos mostrar o sistema pastoril de um grupo de pastores do vale de Santa Maria. Compreender esse sistema pastoril exige entender a relação que se estabelece entre o movimento e a meio à volta. Estes dois aspectos implicam a percepção da paisagem, a qual é internalizada e significada constantemente.

Seguindo esta ideia se buscou organizar o conteúdo da tese com a finalidade de dividir a leitura em duas partes: a primeira, criando as diretrizes de um modelo pastoril de uso do espaço e seus recursos, e a segunda referente ao processo de percepção da paisagem, sendo que as duas instâncias colocam a mobilidade pastoril como eixo central da discussão. Este formato tem como fim discutir esses dois aspectos que são integrados e complementares: as paisagens do movimento.

A proposta de considerar este grupo pastoral dentro de um panorama de paisagens do movimento se dá porque, os trajetos, os caminhos e os lugares são definidos pelo movimento. Este pode ser o próprio deslocamento de um lugar a outro, mas também existe uma multitemporalidade nesses caminhos e lugares, a qual integra passado e presente considerando a macro e a micro história destas pessoas.

\section{2 - De como começou este trabalho}

O vale de Santa María (26 $41^{\prime} 14.93^{\circ}$ latitude Sul- $66^{\circ} 02^{\prime} 56.97^{\circ}$ longitude Oeste, a 1900 metros sobre o nível do mar), está localizado na Província de Catamarca, no Noroeste da Argentina. O vale é atravessado pelo rio Santa Maria, e é um centro de povoamento antigo, apresentando uma ocupação diversa e antiga. A cidade conta com um centro urbano e uma área rural povoada. A atividade do pastoreio tem se focalizado quase que exclusivamente na região das serras. A cidade conta com uma série de localidades que não constam nos mapas oficiais, porém são conhecidas e distinguidas localmente, algumas delas são: Las Mojarras, El Carmén, Fuerte Quemado, Los Altos, Campo de la Simonita, entre outros. Sobre algumas destas localidades se falará nesta tese. 
A escolha do Vale de Santa María não foi casual, a aproximação a este lugar se deu primeiramente por fazer parte de um projeto com o fim de produzir conhecimento arqueológico e antropológico sobre a região, o "Proyecto Yocavil" vinculado ao Museo Etnográfico de la Universidad de Buenos Aires "Juan B. Ambrosetti", dirigido pela Dra Myrian N. Tarragó, e depois junto ao "Proyeto Arqueológico Sierra del Cajón" vinculado à Fundación de História Natural "Felix Azala" e Universidade Maimónides, dirigido pelo Dr Javier H. Nastri.

Nos primeiros anos de trabalho de campo em Santa María, estavam crescendo os movimentos pelo reconhecimento da identidade indígena, muitos grupos estavam integrando-se a estes movimentos. Porém, com o decorrer dos anos, alguns destes grupos se distanciaram desses movimentos. O estudo etnográfico na região começou a mostrar que as instâncias de associação e dissociação dos sujeitos respondia a questões relacionais, principalmente ligadas à esfera de relações que cada uma destas pessoas compreendia e como se organizavam e funcionavam as relações interpessoais em contraste com uma identidade indígena institucionalizada e politizada (ver Acha).

No cotidiano das pessoas do lugar, foi possível perceber que as redes de relações se estabeleciam pela reciprocidade, e que a memória e a tradição ultrapassavam um conceito estabelecido institucionalmente por um movimento e existia no próprio cotidiano de cada um desses sujeitos. A possibilidade de seguir estas pessoas e identificar sua rede de parentes, vizinhos e afins, permitiu conhecer um universo totalmente diferente àquele visto no âmbito do movimento indígena. Estas redes de reciprocidade se estabeleciam entre as pessoas que viviam nas serras, e a integração, a cooperação e o conhecimento existiam como as bases desta estrutura necessária para sua sobrevivência e prosperidade. Assim, trocavam-se produtos locais, conhecimentos e informações, também se cuidavam os animais e as áreas de campo de forma integrada, estas instâncias faziam parte do dia-a-dia das pessoas do lugar e integrado ao reconhecimento da paisagem. Diante destas questões, foi possível ter um contato mais próximo com um grupo que se dedicava quase que exclusivamente ao pastoreio no alto das serras, e é sobre estas pessoas que se desenvolve esta tese.

Especificamente, este trabalho se centra nos pastores da região de Santa María. Os pastores, são pessoas que vivem no que seria a zona rural da cidade e na região serrana, todos eles se dedicam ao pastoreio ou já o fizeram. Os conhecidos fazem parte de uma 
rede de reciprocidade. Todos são pastores, e se reconhecem como tal, apesar de que não integram um grupo étnico propriamente dito, compartilham essa identidade por meio do habitus. É importante aclarar que cada família habita a sua própria casa e tem o seu território, porém estes territórios se sobrepõem - principalmente nas regiões mais altas da serra. Estas pessoas estão em constante contato uns com os outros, se encontram nos caminhos, em visitas informais ou formais, e assim fazem trocas diversas.

\section{3 - Objetivos}

O objetivo geral deste trabalho é o de compreender o sistema pastoril em Santa María. Para tanto, é necessário também abordar questões relacionadas.

Quando falamos de pastoreio o conceito central que sempre surge é o do animal. O pastoreio existe desde e através da domesticação - ainda quando parcial - e do uso de uma ou várias espécies animais. O animal ocupa um papel central juntamente ao meio que dita o ciclo anual de mobilidade que compõe o sistema pastoril.

A paisagem engloba todo o quadro, desse herbívoro associado a outras espécies de flora, fauna até o homem. Esta paisagem define a maneira como os homens interagem com o ambiente na relação entre água, sazonalidade da flora, condições climáticas anuais. Por sua vez, influencia na ordem cultural, considerando: arquitetura, dieta, percepção e transformação da paisagem, além dos hábitos e práticas desenvolvidos na relação direta entre o humano e o animal.

Outra questão central que perpassa todos estes elementos e define o habitus é a mobilidade. Os grupos pastoris tradicionais apresentam estratégias de mobilidade para uma melhor captação dos recursos necessários, para os humanos e para os animais. Portanto, quando pensamos nas estratégias de qualquer grupo sazonal é importante levar em conta a obtenção de recursos e adaptação ao meio, juntamente ao contexto social e político (Chang e Tourtellotte 1993).

Diante destes pontos centrais é possível perceber que, ao mesmo tempo em que se está falando de uma ordem ambiental específica e muitas vezes reguladora, também é intrínseca e inegável a força da filiação cultural. Portanto, ao falar de pastoreio torna-se indispensável pensar nas relações entre humanos e o meio à sua volta. 
Se o pastoreio é um elemento híbrido por excelência, espera-se que os elementos internos também o sejam. Ao decorrer do trabalho surgiram algumas questões específicas que implicavam diretamente na compreensão e na possibilidade de responder à pergunta central:

- $\quad$ Qual é o papel do meio ambiente nesta dinâmica pastoril?

- $\quad$ Como se estrutura este sistema? É possível pensarmos em padrões? Qual é a sua peculiaridade e por que?

- $\quad$ Como se estrutura essa relação entre espaço, ambiente, animais e as necessidades do homem?

- $\quad$ Como é a relação com a paisagem na realidade cotidiana destas pessoas?

- Qual é o papel dos sítios arqueológicos nesta dinâmica?

A resposta a cada uma destas perguntas não foi alcançada de maneira simples. Mas foram estes questionamentos que ordenaram esta tese, tomando como pergunta: Quem são os pastores?

A maneira como esta tese foi ordenada buscou responder a essa pergunta, juntamente buscou-se explanar sobre esse grupo disperso de pessoas que vive e dá vida a uma paisagem onde os elementos do passado e do presente interagem e convivem diariamente. É, a partir desta proposta, que foi possível pensar na construção da tese a partir do diálogo com estas pessoas que integram o sistema pastoril em Santa María.

\section{4 - Sobre o Método, a Etnoarqueologia e a Coleta de Dados}

\section{1 - Sobre o Método e a Etnoarqueologia}

Para este trabalho se escolheu uma abordagem etnoarqueológica, visando identificar as relações entre comportamentos, atividades e seu resultado material. Além disso, a etnoarqueologia também possibilita uma compreensão mais profunda das relações que se estabelecem entre a prática e o simbolismo, propondo uma ótica mais hermenêutica. A etnoarqueologia, permite ao arqueólogo vivenciar o sistema cultural na sua totalidade e apreender os significados e práticas, fundamental para entender os processos ligados à cultura material (Silva 2002; 2011; Hodder 1986; González Ruibal 2003; Politis 2002). 
A etnoarqueologia é um campo da pesquisa arqueológica que tem como foco central a produção de conhecimento arqueológico a partir da coleta de dados originais sobre populações vivas. Há várias definições, porém basicamente se descreve como a aquisição de dados etnográficos originais com fins em: a) gerar conhecimento sobre as sociedades tradicionais e não ocidentais tanto no passado como no presente; b) produzir analogias e referências; c) recursos para testar hipóteses sobre as várias dimensões do passado humano; d) contribuir com o processo da construção e problematização da teoria arqueológica (Politis 2015).

Em casos como o abordado nesta tese, o uso de uma abordagem etnoarqueológica é fundamental para problematizar as diferentes perspectivas de tempo e espaço. Este tipo de abordagem permite ao pesquisador extrapolar as propostas sobre a materialidade e a temporalidade e buscar o contexto específico para grupo em questão. Assim, deu-se preferência a relativizar as categorias desde a perspectiva nativa, considerando a agência dos sujeitos como seres ativos de um sistema. Por sua vez, a etnoarqueologia também permitiu acessar o contexto e os significados.

A etnoarqueologia é uma estratégia de pesquisa centrada no estudo do comportamento humano e da cultura material das populações contemporâneas e parte do pressuposto de que levantar dados etnográficos pode ser útil para a interpretação do registro arqueológico (González Ruibal 2003; Politis2002; Silva 2000, 2009). Este tipo de abordagem exige um diálogo efetivo entre arqueólogos e nativos, além de um rearranjo dos conceitos históricos sobre os conceitos nativos (Ferguson e Colwell-Chanthaphonh 2006), para tanto, toma como ponto de partida a análise etnográfica. Para esta metodologia, o veículo de reprodução da sociedade é a linguagem, a qual apresenta uma função performativa (indexicabilidade e reflexividade), a etnografia busca reconhecer nessa linguagem performática dos sujeitos ativos as ordens sociais naturalizadas (Guber 2011).

\section{2 - Qual etnoarqueologia se buscou trabalhar}

A etnoarqueologia é uma ferramenta de análise que vem crescendo ao longo dos anos. A arqueologia mudou significativamente, principalmente no que concerne à teoria e à compreensão do objeto de estudo, e a etnoarqueologia espelha essas mudanças 
(González Ruibal 2012). O termo etnoarqueologia já era conhecido desde o século XIX, porém ganhou uma maior relevância a partir dos anos 1960. Assim, a etnoarqueologia é retomada nos debates com o fim de levantar dados etnográficos úteis para a interpretação do registro arqueológico (Silva 2011).

Com a arqueologia processual o interesse pelo comportamento de alguns grupos do presente renasce, considerando uma etnoarqueologia embasada numa teoria processualista. A ruptura dos anos 1980, estabelece uma distinção entre o enfoque processualista e o contextualista. Com o pós-processualismo, artefatos deixaram de ser vistos apenas como instrumentos, considera-se que também representam conceitos (David 1992; Silva 2001; 2011).

Os processos tecnológicos e os padrões de comportamento não deixam de ser foco da etnoarqueologia, mesmo com as mudanças propostas pela arqueologia pós-processual. Continuam a ser foco da etnoarqueologia, porém com um enfoque nos contextos sociais e nos processos de aprendizagem e especialização, considerando a dimensão social e simbólica da cultura material (Politis 2015).

Por sua vez, o pós-processualismo não logrou romper com os dualismos cartesianos (natureza/cultura; sujeito/objeto; mente/matéria; sociedade/indivíduo; passado/presente ocidental/não-ocidental etc.). Estas questões abriram espaço para reflexões, principalmente entre aqueles que trabalhavam com grupos não-ocidentais, culminando em uma reavaliação dos métodos e teorias empregadas. Neste contraponto, nos anos 2000 ressurge nos países Anglo-Saxões a arqueologia do passado contemporâneo, e simultaneamente, emerge uma arqueologia com preocupações no presente direto em países como Argentina, Chile, Iran, Espanha, França e países Escandinavos (González Ruibal 2012).

Este momento, coincide com as condições políticas, sociais e econômicas do pósmodernismo, obrigando os arqueólogos a repensar as antigas diretrizes. Identificar e romper com certas barreiras permitiu abrir os olhos aos processos concretos de produção histórica e estabelecer uma ação real, não mais considerando apenas preocupações abstratas sobre a natureza do processo estudado (Gnecco e Ayala 2011). A partir deste momento os arqueólogos estão pensando em interpretar as categorias em seus contextos específicos, tanto histórico como cultural (ver Silliman 2009; Mullin 2011; Shanks e McGuire 1996; Silliman e Ding 2008). 
Com o fim de um século XX e o início do século XXI a arqueologia toma um viés também preocupado com um presente político. A etnoarqueologia abre uma discussão que abrange a ciência arqueológica no geral, colocando a arqueologia como fonte para compreender e problematizar os diferentes pontos de vista sobre o presente e problematizando o passado desde o presente. Assim, a arqueologia se abre para os contextos neocoloniais e cenários sociopolíticos, proteção e políticas de sustentabilidade, mudanças tecnológicas, ressignificação e reapropriação e as diversas perspectivas sobre as paisagens construídas (Politis 2015).

Diante das situações que são enfrentadas atualmente, os arqueólogos foram forçados a repensar uma série de questões, principalmente no que concerne ao objeto de estudo. Esta nova perspectiva teórica e metodológica que vem crescendo e se desenvolvendo, está preocupada e teorizando desde o presente ativo tanto do objeto de estudo como do próprio arqueólogo. Por vezes, esta proposta é vista como exclusiva a estudos etnoarqueológicos, porém representa um processo que está atingindo a toda a disciplina (Politis 2015; González Ruibal 2014; 2012).

Cada vez mais a prática etnoarqueológica tem mostrado como as diretrizes tomam dimensões mais complexas. Ao lidar com a materialidade é importante considerar a sua condição multitemporal, ainda quando se está pensando em um processo do passado é importante entender os diversos contextos temporais de certos objetos de estudo. Ruinas, lugares, objetos do passado podem pertencer ao presente de maneiras muito diferentes. A multivocalidade também tem papel fundamental para considerar uma área e a expressão material diante de uma realidade a curto e a longo prazo (González Ruibal 2012).

Outras questões que vem sendo levantadas são referentes à atualidade das populações tradicionais e à dificuldade de extrapolar dados do presente etnográfico a condições do passado. $\mathrm{Na}$ busca por aperfeiçoar, a etnoarqueologia abriu o leque das perspectivas, buscando cada vez mais acessar as diferentes perspectivas que as populações vivas permitem, considerando: a preservação dos restos materiais (no que concerne à tafonomia, aos processos de formação de um sítio e à manutenção dos mesmos) e como as populações não ocidentais pensam e conceitualizam o registro arqueológico em seu território, independente de assumir ancestralidade ou não (Politis 2015). 
A materialidade presente na humanidade é o tema central de toda análise arqueológica. Por sua vez, a etnoarqueologia ainda é o estudo do universo material das sociedades. Juntamente, a etnoarqueologia tem buscado produzir uma arqueologia mais crítica e integrada, a fim de gerar ideias que favoreçam o debate arqueológico e contribuir com as sociedades com as quais se trabalha. Realocando grupos antes excluídos ao debate das comunidades tradicionais, e dando voz às minorias e a outras formas de referências sociopolíticas. Nesse ponto a América Latina têm gerado importantes contribuições nas últimas décadas (Politis 2015).

\subsection{1 - A Etnoarqueologia nos Andes}

Nos Andes, os estudos etnoarqueológicos têm buscado responder algumas das grandes questões da evolução das economias pastoris, incluindo os processos de domesticação, transformação dos produtos primários e secundários, modo de produção pastoril, inter-relações com os sistemas de produção andinos e transformações sociais (Aldenderfer 2001).

Os Andes são um centro antigo de domesticação de fauna e flora, a origem e as razões dessa domesticação tem sido central na arqueologia andina, assim como os processos de formação de sítio arqueológicos e padrões de assentamento (Kuznar 2001). Um dos grandes problemas dos arqueólogos nos Andes é a definição e distinção dos diferentes modos de produção com o uso de animais, e consequentemente as questões econômicas, sociais, ecológicas, políticas e simbólicas que cada um implica. Diante disso, os estudos etnoarqueológicos podem dar pistas sobre rebanhos e currais, a relação dos diferentes tamanhos, composição e estratégias de gerenciamento. (Aldenderfer 2001).

Portanto, os trabalhos etnoarqueológicos nos Andes têm se mostrado bem sucedidos em investigar padrões modernos em interação com o pastoreio e outros meios de produção. Identificando os modos de produção específicos, e possibilidades de preencher as lacunas das relações entre as particularidades regionais e o processo de articulação das várias regiões andinas, tanto sincronicamente como ao longo do tempo (Aldenderfer 2001).

Por sua vez, a etnoarqueologia permite um enfoque crítico sobre a dominação e a discriminação das comunidades tradicionais andinas, que muitas vezes são vistas com 
desconfiança pelos próprios arqueólogos. Esta desconfiança se centra, por um lado, pelo tempo prolongado da presença europeia, e, por outro, por conta de anos de políticas públicas que colocaram as minorias indígenas em condição de extermínio e inexistência. Principalmente em relação à argentina andina, as comunidades tradicionais foram vistas desde um viés de invisibilidade. Nestes contextos, a etnoarqueologia não é apenas uma ferramenta técnica e metodológica, além das hipóteses e problematizações para as pesquisas arqueológicas, também é uma prática comunicativa que permite confrontar as estruturas pré-estabelecidas (Haber 2001).

Assim, a etnoarqueologia está produzindo informações para contextualizar as informações do registro arqueológico, ao mesmo tempo que também têm um viés político e engajado. Por conta disso, a maioria dos autores concorda que compreender um contexto do ponto de partida etnoarqueológico exige o uso de múltiplas linhas de evidência (Kuznar 2001).

\subsection{2 - Uma proposta interdisciplinar}

Frente à proposta colocada, é interessante considerar uma perspectiva interdisciplinar, para poder alcançar todo o contexto das estruturas sociais e processos individuais e coletivos que se entrelaçam, inclusive com a materialidade. Ainda que esta análise se mantenha fiel à produção etnoarqueológica é fundamental buscar por uma prática integrada, para alcançar todos essas nuances dos discursos comparados a ações e, assim, recriar esse universo a partir do collage das diversas perspectivas, vozes e ações que compõem todo o universo do campo etnográfico.

A tradição arqueológica conhecida como tradição Americana que se estabelece nos países Anglo-Saxões e alguns países da América Latina é fundamentada numa relação mais próxima entre as antropologias e a arqueologia. À diferença da arqueologia Europeia não anglo-saxônica que propõem uma afiliação aos departamentos de história, distinguindo a arqueologia para o estudo de povos da "pré-história", a arqueologia dentro dos departamentos das ciências antropológicas propiciou - e estimulou - a contribuição das etnografias e dos fenômenos arqueológicos (Yarrow 2012).

Esta proximidade entre as áreas promove mudanças nas duas partes, ainda quando

as assimetrias se mantem presente. É possível observar um desenvolvimento diferente 
quanto à prática, metodologia e epistemologia de cada uma das disciplinas, tornando-as diferente nas bases de sua fundação. Assim, a assimetria existe, porém, é plausível de ser dissolvida. Centrando-se na intersecção, sobreposição do encontro das duas áreas, é possível compreender: a) a construção do passado desde e para um presente; b) como certos traços do passado existem em um presente; c) como um grupo é capaz de percebêlos (Shankland 2012).

Um ponto de conexão entre as duas áreas, que vem produzindo trabalhos interessantes, é a relação entre o tempo e a paisagem. Cada vez mais a arqueologia junto à antropologia social, têm se aberto para entender os sentidos por trás das percepções da paisagem dos grupos. A paisagem ultrapassa o conhecimento do dado etnográfico e ordena comportamentos considerando as lógicas de longa duração nas relações homem e ambiente, que, por sua vez, estão em constante mudança (Feld e Basso 1996).

Outro ponto, é a questão do tempo. Para a antropologia o passado está em contínua interpretação, mantendo uma ênfase no presente. A arqueologia permite uma articulação diferente, mesmo quando o foco ainda se mantem no presente. Isto, porque a antropologia ordena suas ideias de um "presente etnográfico" focando no agora do trabalho de campo. A interdisciplinaridade entre estas duas áreas permite circundar o presente, considerando o contexto temporal exposto pela ciência arqueológica (Shankland 2012).

Assim, mesmo que exista a assimetria entre as antropologias e a arqueologia, principalmente no que se refere à natureza da evidência da vida social, estas duas áreas estão buscando alcançar objetivos bem próximos. O interesse da arqueologia não se limita apenas ao objeto em si, busca alcançar o contexto, os significados e os usos relativos às pessoas. Por sua vez, a antropologia busca compreender a maneira como as pessoas pensam e atribuem significados que estruturam as relações (Garrow e Yarrow 2012; Yarrow 2012).

Ainda que uma área busque alcançar as pessoas através dos objetos e a outra busque alcançar objetos através de pessoas, nas duas áreas existem interesses comuns. Ainda quando os meios de abordar os resultados diferem, não são excludentes entre si. Entre arqueologia e antropologia social, existem duas formas, dois métodos, que remetem a formas específicas de fazer ciência. As narrativas base de cada área são diferentes, quanto à referência e exposição de materiais e resultados, ainda assim, é possível trabalhar 
interdisciplinarmente. Por um lado, a arqueologia se vale muito mais das imagens e objetos e a antropologia social, de expressões e narrativas (Hodder 2012).

O fato é que aqui estou tentando traçar uma linha por entre a etnografia e a arqueologia, para falar de sítios e pessoas de maneira integrada e significativa. Proponho abordar estas duas formas e estabelecer um diálogo entre palavras e imagens diante da proposta levantada por Hodder (2012). Portanto neste trabalho tentarei falar com imagens e palavras explicitando os sentidos, sentimentos, sensações e considerações das pessoas com quem se trabalhou.

\section{3 - Sobre a coleta de dados}

Especificamente, este trabalho se centra em algumas famílias de pastores da região de Santa María. Conhecer estas famílias foi um processo de vários anos. Assim, dentro deste grupo de pessoas dispersas pelas serras, esta tese se centra em algumas famílias especificamente, pois participar da vida destas pessoas implica em seguir várias histórias concomitantes que muitas vezes podem resultar confusos quando a proposta da tese é fazer com que dados sejam inteligíveis.

A escolha dos interlocutores se deu na sua maioria ao acaso, algumas era pessoas que estavam relacionadas aos projetos arqueológicos dos quais se participou e estas pessoas indicaram outras. Em questão de localidades buscou-se um número interessante de lugares para poder estabelecer padrões dentro do vale de Santa María, porém a extensão do vale e o tempo hábil de produção de uma tese de doutorado exigiram alguns recortes. Desta forma, os dados coletados de central nas seguintes localidades: Santa María (Catamarca), El Carmen (Tucumán) e Tafí del Valle (Tucumán). Trabalhou-se também com os relatos de memórias dos interlocutores, permitindo acessar três gerações de uma mesma família. As memórias abarcaram outras localidades, além das já citadas, como El Mollar (Tucumán), Los Altos (Catamarca), Águas Calientes (Catamarca).

Em relação às diferentes gerações, aqueles relatos que representam a primeira geração (mais distante no tempo), implicam em 6 famílias respectivamente, uma (1) em Santa María (interior da serra del Cajón), duas (2) em Tafí del Valle, uma (1) em El Mollar, uma (1) em El Carmen e uma (1) em Águas Calientes. 
A segunda geração (aquelas pessoas que hoje apresentam idades entre 65 e 80 anos aproximados) são representadas 5 famílias, duas (2) em Tafí del Valle, uma (1) em Santa María (interior da serra del Cajón), duas (2) em El Carmen.

A terceira geração (aquelas pessoas que hoje apresentam idades entre os 35 e 60 anos aproximados) são representadas por 7 famílias, quatro (4) em Santa María (1 no centro urbano, 2 próximas ao centro urbano e 1 no interior da serra del Cajón), duas (2) em El Carmen, uma (1) em Tafí del Valle (próximo ao centro urbano).

A figura abaixo indica os lugares dos quais de obteve informação. De acordo aos dados coletados, abarcou-se uma área que inclui vales mais úmidos, mais à direita da figura - como é a zona de Tafí del Valle - e vales mais áridos e altos, no extremo esquerdo da figura - representada pela zona de Agua Calientes -. Ainda assim, a maior concentração de informações se centrou na zona referente à serra do Cajón, entre as aforas da cidade de Santa María e El Carmen, na figura a área indicada pelo pontilhado na cor azul.

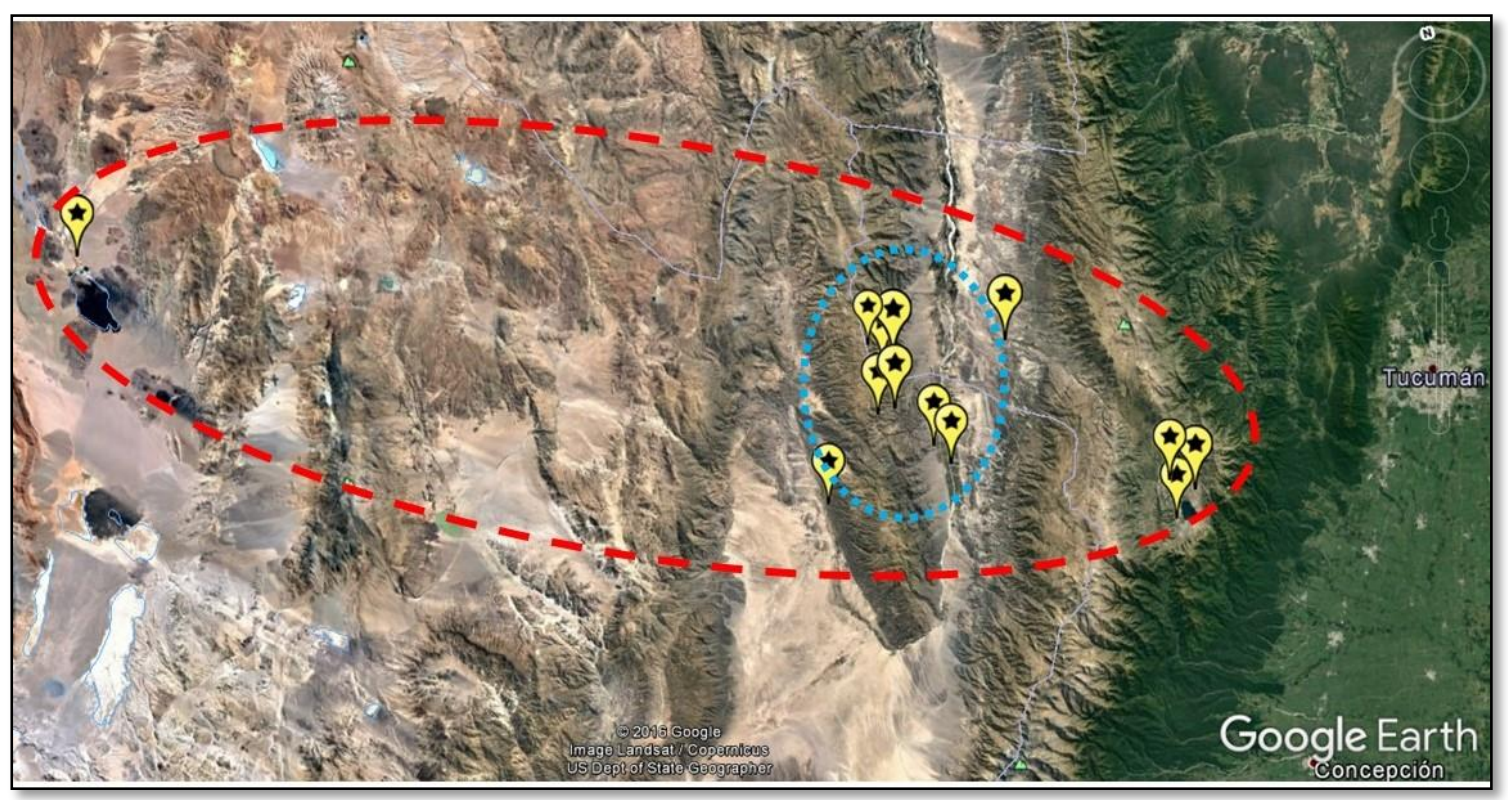

Figura 1 - Mapa indicando a área total abarcada pela coleta de informações. Destacando-se os locais dos interlocutores.

Ao todo trabalhou-se com 9 famílias. Conforme a questão dos hábitos pastoris ficou mais claros foi possível estabelecer padrões entre os comportamentos, 
principalmente na relação entre os hábitos pastoris e as gerações em questão havia comportamentos muito similares entre as famílias. Visando isso, e buscando propiciar uma leitura mais fluida, buscou-se integrar as informações dos interlocutores em eixos centrais para orientar a discussão. Desta forma, eventos e falas foram integrados em 3 núcleos centrais, definidos como famílias, a fim de fazer a leitura mais fluida e o leitor seguir o fluxo da análise do pesquisador.

A integração de informações em cada eixo foi feita a partir das características relativas: $1^{\circ}$ ) aos elementos presentes na prática pastoril (produção, tipos de trocas, tipos de venda); $2^{\circ}$ ) ao tipo de animal do rebanho; $3^{\circ}$ ) às relações entre as gerações.

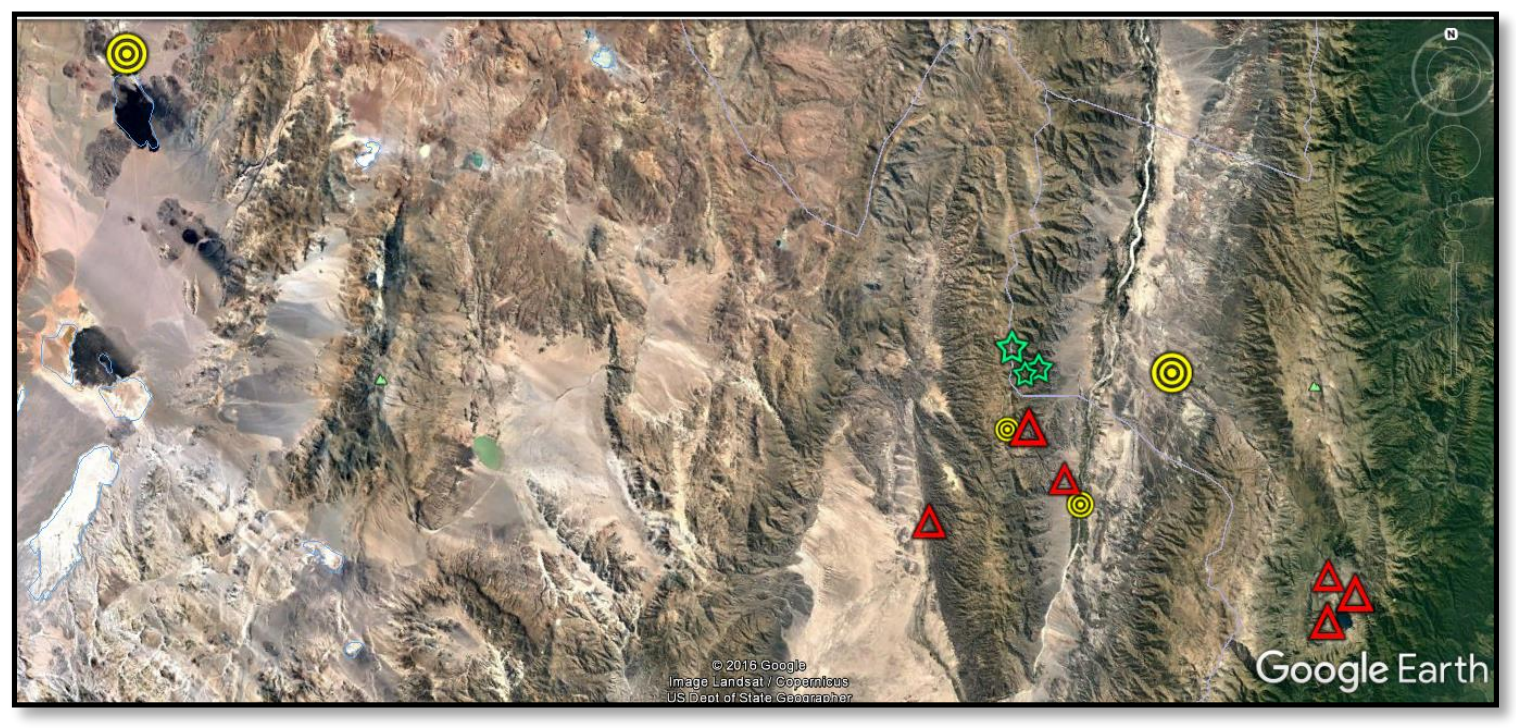

Figura 2 - Mapa indicando a associação de informação de interlocutores. As diferentes cores (amarelo, vermelho e verde) representam os padrões mais semelhantes.

A figura anterior indica os pontos de coleta de informações no mapa e aqueles que são selecionados nos três eixos centrai. De acordo às cores do mapa: a) cor amarela representa "Guadalupe e sua família"; b) cor vermelha, representa a "Dom Vicêncio e sua família"; c) cor verde representa "Dom Yucra e sua família". Ao longo desta tese encontraremos as histórias destas três famílias de pastores:

\section{1-) Guadalupe e sua família}


Guadalupe e Don Lorenzo são irmãos e cresceram com os avós que eram pastores em Águas Calientes (localidade próxima), quando vieram a Santa María - cada qual em épocas diferentes - Guadalupe se estabeleceu mais próximo à cidade para trabalhar e D. Lorenzo vive com seus animais em um campo no alto da serra. Guadalupe tem quatro filhos, três meninos e uma menina, como as crianças estavam acostumadas à vida na serra tiveram dificuldade em se adaptar à cidade, por isso durante muitos anos viveram por lá com D. Lorenzo e assistiam à escolinha da serra em El Carmén. Os dois filhos maiores de Guadalupe voltaram para a cidade para cursar o ensino fundamental, porém retornam à serra sempre que possível.

D. Lorenzo vive na serra, ele se dedica ao pastoreio exclusivamente, junto com ele vive seu filho adotivo Francisco, porém durante a semana o menino fica na casa de Guadalupe para poder ir à escola.

\section{2-) Don Vicêncio e sua família}

Don Vicêncio vive na localidade de Las Mojarras, próximo à casa de Domingo, porém mais adentro na serra. Devido a sua idade ele já não sobe mais à serra, mas ainda tem alguns poucos animais que vivem na sua pequena chácara. Por não poder cuidar de seu campo ele o aluga para D. Lorenzo, porém, várias vezes em datas específicas ele comparece à serra com a família. D. Vicêncio é casado com Dona Maria, a casa do alto das serras era dos pais dela, pois ele é de uma outra localidade chamada Los Altos, quando se casaram foram viver no alto das serras e depois de quinze anos foram para Las Mojarras.

Eles têm vários filhos e muitos netos, alguns deles não são pastores, mas a maioria sim. Don Vicêncio conta que ia com seus filhos e netos todos os dias pelas manhãs e tardes para a serra e lhes mostrava os lugares e lhes contava as histórias de cada um destes lugares. Porém, Lucila, a neta mais velha, não teve a oportunidade de ir com o avô, porque ela era muito pequena para acompanhar os tios e já não acompanhou os primos, ela tem muita curiosidade e um sentimento de compromisso em conhecer os espaços que seu avô conhecia na serra e sempre que pode ela tenta reconstruir os caminhos que ele lhe conta.

\section{3-) Dom Yucra e sua família}

Dom Yucra vive em El Carmen, ao lado da escolinha da serra (frequentada pelos filhos de Guadalupe), este homem sempre foi pastor e continua sendo. Apesar da idade 
avançada ele ainda vive no mesmo lugar em que vivia com sua mãe, porém em outra casa. Além de sua casa ainda tem a de sua filha, que nos últimos anos se mudou para a cidade de Santa María.

Por sua vez, respondendo aos preceitos de ética do investigador, buscou-se manter a integridade dos interlocutores, portanto os nomes foram trocados apesar de ainda ser fiel quanto às relações familiares e às descrições físicas destes. Os eventos mostrados muitas vezes podem aparecer trocados e reordenados a fim de dar fluidez à construção da tese, respondendo às perguntas centrais destacadas nos objetivos desta tese.

Para a coleta de dado, fez-se uso da observação participante orientada arqueologicamente, dando uma especial atenção à materialidade do grupo em questão, buscando evidenciar a relação que constituem um sistema pastoril de acordo à mobilidade, identidade, registro arqueológico e à constituição da paisagem.

A coleta de dados foi feita em conjunto com a equipe arqueológica dos Projetos citados anteriormente ${ }^{1}$. Ser parte de um projeto, respondendo à necessidade de mais de uma pessoa, permitiu ter um panorama mais estendido, principalmente no que se refere à paisagem. A possibilidade de estar lidando com outras variáveis, que não apenas as minhas perguntas, permitiu-me abrir o leque dos contextos e, principalmente, pensar a mobilidade como um fato social total.

Como forma de levantar hipóteses e respostas, o trabalho de campo é parte fundamental, a informação recolhida - através do método etnográfico - permitiu vivenciar os sujeitos no seu próprio contexto e dinâmicas, das interações e das significações nativas. Assim, em posição de executores e produtores da sua realidade social, vemos um grupo de pessoas redigindo a seu dia-a-dia e levantando uma série de proposições sobre o que é o mundo que os rodeia e o que significa para eles.

A fim de compreender a lógica única do campo foram feitas etapas de trabalho de campo nas diferentes estações no ano, buscando abarcar o comportamento ao longo de um ciclo anual completo. Destacam-se os seguintes períodos: 2004, junho e julho; 2008, março e abril/setembro e outubro; 2010, fevereiro (7 dias) e outubro (10 dias); 2012 julho

\footnotetext{
${ }^{1}$ Participou-se do Proyecto Yocavil do ano 2008 ao ano 2011 e do Proyecto Arqueológico Sierra del Cajón do ano 2010 ao ano 2016. Ainda, foram utilizados alguns dados etnográficos coletados durante o período de pesquisa para elaborar o trabalho de conclusão de curso da graduação em Ciências Sociais na UNESP, anteriormente à participação em estes projetos.
} 
e agosto (15 dias); 2013 novembro e dezembro; 2015 junho e julho ${ }^{2}$. Desta forma, estevese presente nos períodos de outono, inverno e verão. As atividades que se levaram a cabo em essas etapas de campo responderam a duas lógicas: a) as atividades cotidianas dos interlocutores; b) atividades orientadas etnoarqueologicamente.

Acompanhar as atividades cotidianas permitiu compreender a lógica das ações e dos lugares que estas aconteceram. Dentro desta gama de atividades diversificadas foi possível identificar uso do espaço (divisão de atividades e divisão do espaço), ocupação e territorialidade, obtenção de matéria prima e alguns processos de produção e reconstrução dos registros materiais. Também forma acompanhadas atividades extraordinárias, como são os passeios.

Por sua vez, como atividades orientadas se buscou cobrir outro tipo de informação complementar à obtida nas atividades com os interlocutores. Assim, os mesmos lugares foram visitados em várias horas diferentes do dia para compreender a dinâmica (por exemplo os locais de currais junto à casa residencial), e os caminhos forma percorridos (previamente ou novamente) sem a presença dos interlocutores para atestar tanto a possibilidade de seguir as designações de rotas e trajetos, como a identificação dos elementos distintivos.

Na etapa de análise e construção da tese, buscou-se organizar os relatos orais, situações e eventos, de maneira a permitir ao leitor identificar na lógica do campo os conceitos e os pressupostos que estão sendo discutidos. Desta forma, o trabalho empírico modela a descrição da tese e também permite rediscutir categorias desde outras óticas.

\section{5 - Resumo dos Capítulos}

Esta tese está organizada em cinco capítulos e as reflexões finais. O primeiro capítulo (Capítulo 1) consiste em uma introdução ao contexto de Santa María, explicitando: clima, topografia, fauna, flora e história humana. O segundo capítulo (Capítulo 2) apresenta uma introdução ao sistema pastoril que foi observado em Santa María. A partir das distinções entre: modo de produção, mobilidade, tipo de animal,

\footnotetext{
${ }^{2}$ Destes períodos de campos alguns foram junto às equipes arqueológicas e outros foram momentos de campo solitário.
} 
divisão do trabalho, divisão de áreas e as instituições, definir-se-ão as classificações desse sistema pastoril, visando estabelecer as bases e distinções que o caracterizam.. Também, serão discutidos os elementos do sistema pastoril considerando o debate atual sobre os modos de produção pastoril e suas implicações. Na última parte do capítulo serão levantadas discussões sobre as implicações humanas e animais no processo pastoril.

No terceiro capítulo (Capítulo 3) a discussão se centra na mobilidade pastoril. A partir da definição da natureza dos movimentos, discutir-se-á com que tipo de sistema de mobilidade se está tratando. Ao mesmo tempo em que a mobilidade tem implicações ambientais reais, também apresenta uma influência direta no comportamento material destas pessoas, definindo três tipos de assentamentos: casa da cidade, casa de campo e postos temporários. O capítulo 2 e o Capítulo 3 apresentam as bases do modelo pastoril de Santa María.

O quarto capítulo (Capítulo 4) é introduzido com uma discussão sobre as análises da paisagem, lugar e movimento. Diante da relação estreita com os caminhos da mobilidade pastoril, este capítulo apresenta as diretrizes para compreender o que significam os caminhos neste contexto pastoril de Santa María. O capitulo finaliza com a experiência de seguir os caminhos junto a um pastor, permitindo contextualizar as classificações abordadas ao decorrer do capítulo.

O último capítulo (Capítulo 5) apresenta a experiência das paisagens contemporâneas. A discussão se centra em três áreas delimitadas artificialmente, estas áreas foram representativas no seu passado, por isso o capítulo mostra uma descrição arqueológica de cada uma das áreas e as atividades atuais que se levam a cabo nesses locais na atualidade. A intenção do capítulo é indicar como muitos locais continuam sendo significativos, ainda que em contextos diferentes a relação com os recursos ainda é vigente.

O capítulo de conclusão (Reflexões Finais), fará um levantamento geral dos temas abordados nesta tese. Começando com uma discussão sobre as áreas de ocupação e a possibilidade de estabelecer áreas de maior potencial arqueológico para a região do vale de Santa María, expondo algumas hipóteses sobre a importância pastoril para o incremento da complexidade social no passado desses vales. A discussão também se abre às questões que a vida moderna coloca a estas populações pastoris, problematizando questões sobre as mudanças e adaptabilidades que estão vivendo atualmente. Esta 
discussão coloca esta tese dentro do eixo das discussões etnoarqueológicas sobre a cultura material, junto a um viés mais crítico a favor da comunidade com a qual se está trabalhando. 


\section{1 - CHEGANDO A SANTA MARÍA. Uma}

introdução.

Este capítulo tem a função de introduzir o leitor no ambiente do vale de Santa María e na vida dos pastores que habitam este vale a fim de dar início à discussão central desta tese. $O$ capítulo começa com uma breve descrição do vale, expondo as características geomorfológicas, climáticas, fauna e flora. O capítulo finaliza com um levantamento da história humana nesse vale.

A proposta deste capítulo é mostrar as peculiaridades deste ambiente e a persistência do modo de produção pastoril ao longo dos anos. Apresenta um viés puramente descritivo a fim de dar as bases para as discussões que tomam lugar ao logo da tese.

\section{1 - Chegando a Santa María}

Pela estrada, a menos de duzentos quilômetros encontra-se Santa María. Na verdade, não há placa que anuncie Santa María. Mas há aqueles que conhecem o caminho e sabem que o rumo está certo, por causa do anúncio de uma ou outra cidade próxima. A província é Catamarca, mas se toma o rumo por Tucumán. Seguindo pela estrada provincial $N^{o} 307$, entre as plantações de cana de açúcar e milhares de motos que estão levam e trazem crianças com roupa de escola, o cartaz anuncia San Miguel de Tucumán, Tafí del Valle e Catamarca. A serra vai ficando cada vez mais próxima, cada vez maior. A serra ocupa todo o horizonte, os Andes crescem diante dos olhos como uma muralha infinita.

O caminho até Santa María não é longo, é demorado. É preciso abandonar o ar tropical das planícies e ingressar na aridez dos vales andinos e isso toma tempo e voltas 
na subida da montanha. Conforme a ondulação das montanhas começa a aparecer no terreno, as grandes plantações ficam para trás e a vegetação vai tomando lugar entre as casas e pequenas chácaras. Uma imensidão de floresta tropical aparece diante dos olhos, bromélias e árvores altas cobertas de trepadeiras e lianas surgem, a umidade e o calor que saem da floresta são agradáveis. A estrada dá voltas ao redor da montanha verde e folhada, a subida é intensa e o sol se esconde nas encostas e nas grandes copas das árvores. Porém, conforme a altura avança, o aspecto do bosque vai mudando, de denso e tropical vai-se transformando em um bosque de inverno, a umidade faz-se neblina e já não se vê o céu, as árvores começam a ficar espaçadas e aparece uma pastagem de solo que despenca nas encostas como samambaias do frio. A temperatura cai abruptamente e pedras e matos fazem-se visíveis. Quase no topo, as poucas árvores ficam cada vez mais baixas e retorcidas, a pastagem do solo faz-se mais intensa e amarelada e então, numa última volta da estrada, adentra-se ao que antes se via no céu. É preciso atravessar nuvens para alcançar os vales andinos.

O primeiro vale deste lado da pré-cordilheira ainda recebe frequentes ventos e massas de umidade que se formam na floresta abaixo. É um vale úmido com pasto e grama. Olhando-se para cima, as altas montanhas ainda conservam um pouco dos bosques que, no inverno, são vistos como fileiras de palitos sem folha. Os picos são altos. É necessário continuar subindo para atravessar o vale, a vista das duas pequenas cidades e do dique vai ficando para trás. A estrada começa a passar por pastos e fazendas, com vacas e cavalos bonitos e peludos, algumas ovelhas, burrinhos e inúmeras ruínas arqueológicas no caminho. Da subida íngreme abrem-se longas fileiras de serras com ondulações suaves e cobertas de vegetação, a estrada segue larga e calma, subindo e indo entre as pastagens e o sol que assoma por entre nuvens e picos.

No vai-e-vem da estrada, a vegetação muda, o solo muda, largas galerias de pedras junto ao que parece areia abrem-se diante dos olhos, a cor verde e suave torna-se avermelhada e amarelada. A vegetação praticamente some e reaparece o sol, com a força e a secura com que ele brilha nestas alturas. A cabeça dói e o corpo tenta adormecer. $\mathrm{Na}$ estrada, cartazes anunciam o risco por causa da erosão e das grandes pedras que, às vezes, caem no asfalto. Com o sol castigando a nuca, olha-se para trás e o que se vê é um imenso lago branco de nuvens, como a última lembrança da umidade tropical. 
Ao avistar o vale, as montanhas vão se suavizando, uma tímida vegetação vai aparecendo aos poucos entre as rochas. $\mathrm{O}$ solo vermelho argiloso faz-se uma areia branca e leve. Ao longe vê-se como o vento a carrega de um lado a outro deixando o horizonte esfumaçado. A secura do sol e do solo percebe-se nas mãos e nos lábios. Seguindo o rio Santa María, o aspecto das encostas vai mudando, alguns lugares são mais pedregosos e outros menos.

O vale de Santa María constitui o ambiente morfoestrutural do que chamam Serras Pampeanas. Estando demarcado pela Serra do Cajón a Oeste e pela Serra do Aconquija a Leste, o vale desenvolve-se numa depressão tectônica de direção Norte/Sul, por onde corre o rio Santa María.

O rio Santa María é o principal coletor do vale. Atravessa de sul a norte, recebendo água dos afluentes que, geralmente, são estacionais e de caudal escasso. O rio apresenta um déficit hídrico o ano todo, reduzindo drasticamente seu volume nos meses de estiagem (de abril a outubro) e, inclusive em alguns lugares, inume-se por completo o leito.

Quando o rio está seco, a imensidão do espaço de pedra e areia que deixa a vazante do verão impressiona e é preciso atravessar essa imensidão vazia para chegar a Las Mojarras. Porém, o rio seco permite que se tomem atalhos, várias ruas descem e sobem conectando pontos mais próximos sem ter de tomar a ponte localizada numa avenida central de Santa María. Fica mais próximo seguir pelo atalho à casa de Dom Vicêncio. O vento seco segue levando a terra de um lugar a outro. Ao deixar o caminho principal e fazer a curva para entrar na propriedade de Dom Vicêncio, abre-se uma longa planície de areia com alguns poucos arbustos que, às vezes, as crianças usam como quadra de futebol. Ali, a terra já começa a mostrar as suas subidas e deixa de ser vale. Diante dos olhos, está a imensa Serra do Cajón, seca e cheia de rochas dentre as quais podemos ver alguns churquis (Acacia caven Mol), breas (parkinsonia praecox) e um campo de cardones (triclocereus pasacana) acompanhando as subidas e as ruínas arqueológicas do Pucará3 . Esta serra guarda toda a história e caminhos destas famílias de pastores que aqui apareceram.

\footnotetext{
${ }^{3}$ O Pucará é um sítio arqueológico vastamente estudado (ver Tarragó 2000; Tarragó 2011; Tarragó e Scattolin 1999). O nome do sítio provém de sua estrutura arquitetônica que faz acreditar que seja uma área de vivenda e também de defesa.
} 
A Serra do Cajón ${ }^{4}$ leva esse nome pela sua forma prismática retangular, determinada por duas falhas paralelas de rumo meridional e de aproximadamente $100 \mathrm{~km}$ de profundidade. Os picos mantêm-se em uma média de $3.500 \mathrm{~m}$ (diferentemente das principais elevações da Serra do Aconquija que alcançam e superam os $5.000 \mathrm{~m}$ ). As precipitações nesta serra são ainda mais escassas do que são no vale. A precipitação anual no vale de santa María é baixa, 200mm anuais em média e, na serra podem ser observados $150 \mathrm{~mm}$ por ano. Isto porque o elevado cordão montanhoso do Aconquija constitui uma barreira orográfica que impede a circulação das massas úmidas provenientes do Atlântico. A vegetação característica na região é constituída por: xerófitas, ervas curtas e baixas que cobrem o solo árido e pedregoso de forma descontínua. Os arbustos são de troncos retorcidos e rasteiros, em geral com espinhos.

Ao deixar o caminho cheio de poeira para trás e atravessar a areia pesada do campinho, vejo dois cachorros e pintinhos que passam fazendo barulhos mil. Entre os sons dos animais que dão vida a esta imensidão árida, atrás de árvores há muito plantadas, está a casa de Dom Vicêncio. Ao chegar, vem o cheiro da lenha queimada e algumas pessoas levantam-se para receber. No instante que desço do veículo e sorrio, já sinto meus lábios cortados e as mãos e cutículas esbranquiçadas devido ao clima seco.

\section{2 - O Vale de Santa María. Características}

\section{1 - Características gerais}

Santa María está localizada ao norte da província de Catamarca. É um dos departamentos mais distantes da capital (San Fernando de Catamarca). Seu acesso dá-se pelo território da província de Tucumán, pela estrada Provincial №307. Esta estrada ingressa na cordilheira dos Andes, vinculando a planície tucumana aos vales Calchaquíes.

A cordilheira dos Andes estende-se na direção Norte-Sul da América do Sul, paralela à costa do Pacífico. Originou-se na era Terciária, e lhe são características grandes altitudes e intensa atividade vulcânica. Na porção argentina, a parte oriental desta cadeia montanhosa é constituída por bloques antigos que formam planaltos escalonados em direção ao Este, recobertos por depósitos eólicos; esta formação é entrecortada por vales

\footnotetext{
${ }^{4}$ Cajón, em espanhol, significa gaveta.
} 
fluviais. Um dos afloramentos desta formação é conhecido como Serras Pampeanas e constitui-se de uma série de cadeias montanhosas localizadas ao Este da cordilheira Frontal. As serras que constituem este sistema formam-se em blocos paralelos separados por vales estreitos e alargados. A cordilheira Frontal está constituída por um longo cordão de blocos independentes de grande altitude, sem direção geral uniforme, separados por vales fluviais profundos que descem da cordilheira Principal. Neste sistema, são frequentes altos picos (superando os $6000 \mathrm{~m}$ ). Adossada a este sistema está a cordilheira Principal.

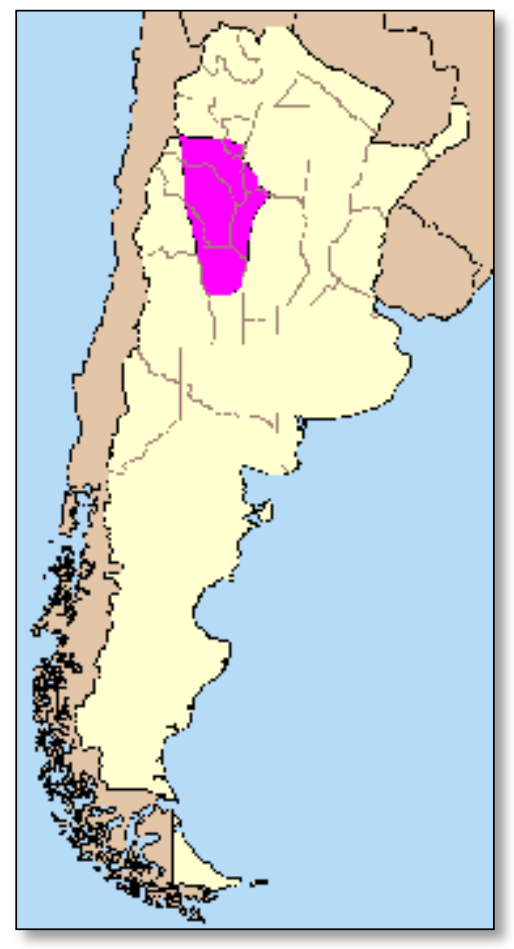

Figura 3: Mapa indicando a Formação das Serras Pampeanas no território argentino. Fonte: https://es.wikipedia.org/wiki/Sierras_Pampeanas\#/media/File:Sierras_pampeanas1.png, De The original uploader was LadyInGrey de Wikipedia en español - Transferido desde es.wikipedia a Commons., CC BY-SA 3.0

Portanto, a cordilheira dos Andes constitui-se como um escudo às massas úmidas provenientes do oceano Atlântico que percorrem as bacias sedimentais que unem o oceano às montanhas. Nas planícies subtropicais com verões cálidos de Tucumán, as massas de umidade que se deslocam em direção à cordilheira perdem grande parte da umidade ao longo do percurso. Ao alcançar a cordilheira, estas massas de ar passam a ter uma característica de ventos secos e frios (somente aumenta a porcentagem de umidade quando se combinam com as massas de ar procedentes da zona antártica). O encontro dos ventos provenientes do pacífico com estas massas de ar provenientes do Atlântico, aliado 
à grande variabilidade geomorfológica condiciona uma grande variedade de climas locais, entre eles o de Santa María. Do clima Subtropical cálido das planícies, conforme se avança na subida da cordilheira, passa-se ao clima de Tafí del Valle, que já é indicado como BSkbw, estepe-frio com verão temperado e inverno seco. Na ladeira oriental do Aconquija, o clima já se transforma em Cwb (temperado com inverno seco), e paulatinamente vai passado ao clima tipo Cwa (subtropical com estação seca) (Marranghello et al 2000).

Desta forma, os diversos microclimas nos vales andinos, conforme se adentra a cordilheira, caracterizam as paisagens desta zona selvática e subtropical até a aridez dos altos picos da cordilheira dos Andes. A província de Catamarca faz parte da região histórico-geográfica, conhecida como Noroeste Argentino e inclui as províncias de Jujuy, Salta, Tucumán, La Rioja e Santiago del Estero (Tineo 2005).

Em particular, a província de Catamarca caracteriza-se pelo relevo montanhoso que ocupa grande parte da sua superfície. Catamarca está no que se consideram os vales áridos, zona de extrema aridez com chuvas intensas de curta duração concentradas na época estival. Nesta província, a precipitação média anual condiz com 160mm nos meses de verão, sendo quase nulas no restante do ano. Conforme se avança ao interior da cordilheira, as chuvas vão diminuindo ainda mais em frequência, como é possível observar no seguinte quadro:

\begin{tabular}{|c|c|c|c|c|c|c|c|c|c|c|c|c|c|c|}
\hline Lugar & Fuente & $E$ & $F$ & $\mathrm{M}$ & $A$ & $M$ & $\mathrm{~J}$ & $\mathrm{~J}$ & $\mathrm{~A}$ & $\mathbf{S}$ & 0 & $\mathrm{~N}$ & $\mathrm{D}$ & Año \\
\hline $\begin{array}{l}\text { Tinogasta } \\
(1971 / 82)\end{array}$ & AyEE & 45.3 & 38.0 & 16.9 & 3.0 & 1.0 & 1.1 & 1.8 & 1.0 & 3.2 & 4.1 & 17.2 & 12.7 & 145.3 \\
\hline $\begin{array}{l}\text { Pie de } \\
\text { Médano } \\
\text { (1971/82 }\end{array}$ & AyEE & 54 & 45 & 18 & 3 & 1 & 0 & 0 & 0 & 3 & 5 & 8 & 33 & 170 \\
\hline $\begin{array}{l}\text { Playa Larga } \\
\text { Rio Belén } \\
(1971 / 82)\end{array}$ & AyEE & 71 & 73 & 38 & 11 & 2 & 0 & 2 & 1 & 1 & 6 & 9 & 30 & 244 \\
\hline $\begin{array}{l}\text { Santa María } \\
(1978 / 87)\end{array}$ & INTA & 75 & 40 & 24 & 7 & 1 & 0 & 0 & 0 & 3 & 4 & 17 & 36 & 207 \\
\hline $\begin{array}{l}\text { Andalgalá } \\
\text { (1954/77) }\end{array}$ & SMN & 79.1 & 86.6 & 50.7 & 9.0 & 8.6 & 4.1 & 9.3 & 6.8 & 3.8 & 8.0 & 16.6 & 29.6 & 301 \\
\hline
\end{tabular}

Tabela 1 - Precipitações mensais na província de Catamarca. De acordo com os departamentos selecionados. Fonte: Tineo: 2005: 68.

A temperatura média anual varia entre os $16^{\circ} \mathrm{C}$ e os $18^{\circ} \mathrm{C}$, as geadas são frequentes e ocorrem durante um período médio de 120 dias ao ano. O vento apresenta maior 
intensidade durante os meses de agosto a setembro, soprando em direção Sudoeste, com velocidades que variam de $15 \mathrm{~km} /$ hora a $20 \mathrm{~km} /$ hora, até $70 \mathrm{~km} /$ hora a $90 \mathrm{~km} / \mathrm{hora}$. Durante o inverno, esporadicamente, sente-se o vento Zonda, vento cálido e seco responsável pelo movimento de muita matéria. É um vento que se origina no Pacífico Sul e ingressa pela porção mais alta da Cordilheira dos Andes na Argentina, trazendo chuvas e nevadas; este vento é responsável por uma série de lendas e ditos nas regiões onde sopra. A manifestação destes fortes ventos, associada a fatores climáticos de aridez extrema, acentua a instabilidade dos solos e provoca uma intensa erosão eólica, formando dunas ou acumulações de materiais, obrigando os habitantes da região a abandonar cultivos, moradias e povoados, nos casos mais extremos (Tineo 2005).

Cuadro 2. Temperaturas Medias Mensuales en ${ }^{\circ} \mathrm{C}$

\begin{tabular}{|l|c|c|c|c|c|c|c|c|c|c|c|c|c|}
\hline \multicolumn{1}{|c|}{ Lugar } & E & F & M & A & M & J & J & A & S & O & N & D & Año \\
\hline Tinogasta & 25,1 & 24,1 & 21,3 & 17,5 & 12,6 & 9,1 & 8,9 & 12,8 & 15,9 & 19,7 & 22,5 & 15,5 & 17,9 \\
\hline${ }^{*}$ Fiambalá & 21,9 & 21,1 & 19,0 & 15,6 & 12,1 & 8,9 & 8,7 & 11,0 & 14,1 & 17,4 & 20,0 & 21,8 & 16,0 \\
\hline * Belén & 22,4 & 21,6 & 19,5 & 16,1 & 12,7 & 9,4 & 9,2 & 11,4 & 14,4 & 17,8 & 20,3 & 17,8 & 16,4 \\
\hline Andalgalá & 25,1 & 24,0 & 21,9 & 17,9 & 13,7 & 9,9 & 10,0 & 12,6 & 16,7 & 20,1 & 22,9 & 25,0 & 18,3 \\
\hline
\end{tabular}

Tabela 2- Temperaturas médias anuais na província de Catamarca. Fonte: Tineo: 2005: 69.

O departamento de Santa María está localizado ao norte da província. Apresenta uma economia que se baseia na atividade agrícola de aromáticos, vinhedos e nogueiras. A atividade agropecuária estende-se nas bordas desérticas onde a falta de água não permite o desenvolvimento agrícola. Conta com ovinos, caprinos e camelídeos (lhamas). Os camelídios estão concentrados principalmente na região da Puna, da qual se obtém couros e lãs para atividade têxtil artesanal. A atividade industrial neste departamento é reduzida. Caracteriza-se pela produção de doces e produtos domésticos artesanais. Diferente do restante dos vales do Noroeste Argentino, o turismo em Santa María é reduzido, ainda está em desenvolvimento inicial (Tineo 2005). 


\begin{tabular}{|c|c|c|c|c|c|}
\hline \multirow{2}{*}{\multicolumn{2}{|c|}{ Departamento }} & \multirow{3}{*}{$\begin{array}{c}\text { Superficie } \\
\text { Sistematizada }\end{array}$} & \multirow[t]{3}{*}{ Total } & \multirow{2}{*}{\multicolumn{2}{|c|}{$\begin{array}{c}\text { Superficie regada } \\
\text { Fuente de Agua }\end{array}$}} \\
\hline & & & & & \\
\hline & & & & Superficial & Subterranea \\
\hline \multirow{2}{*}{ Andalgalá } & EAPS. & & 577,0 & 566,0 & . \\
\hline & Ha. & $3.359,5$ & $2.624,2$ & $1.889,2$ & 479,0 \\
\hline \multirow{2}{*}{ Ant. de la Sierra } & EAPS. & & 90,0 & 90,0 & . \\
\hline & $\mathrm{Ha}$. & 56,6 & 56,0 & 56,0 & . \\
\hline \multirow{2}{*}{ Belén } & EAPS. & & 637,0 & 637,0 & . \\
\hline & Ha. & $3.876,3$ & $2.650,3$ & $2.650,3$ & . \\
\hline \multirow{2}{*}{ Pomán } & EAPS. & & 787,0 & . & . \\
\hline & $\mathrm{Ha}$. & $1.599,3$ & $1.525,0$ & . & . \\
\hline \multirow{2}{*}{ Santa María } & EAPS. & & 579,0 & 284,0 & 15,0 \\
\hline & Ha. & $2.871,2$ & $2.309,2$ & 891,4 & 104,6 \\
\hline \multirow{2}{*}{ Tinogasta } & EAPS. & & $1.744,0$ & $1.741,0$ & . \\
\hline & Ha. & $6.585,1$ & $5.458,8$ & $4.868,3$ & . \\
\hline \multirow{2}{*}{$\begin{array}{l}\text { Total } \\
\text { Departamentos de } \\
\text { interés }\end{array}$} & EAPS. & Sin datos & 4.414 & 3318 & \\
\hline & $\mathrm{Ha}$. & $18.348,4$ & $14.623,5$ & $10.355,2$ & 583 \\
\hline \multirow{2}{*}{ Total Provincial } & EAPS. & - & $5.925,0$ & $5.604,0$ & 29,0 \\
\hline & Ha. & $39.471,9$ & $28.474,9$ & $24.383,6$ & 827,6 \\
\hline
\end{tabular}

Tabela 3 - As explorações agropecuárias à base de irrigação, na província de Catamarca. Dados referentes aos anos de 1987-88. Fonte: Tineo: 2005: 78.

\begin{tabular}{|l|r|r|r|r|r|r|}
\hline \multicolumn{1}{|c|}{ Gran División } & $\mathbf{1 9 9 1}$ & $\mathbf{1 9 9 2}$ & \multicolumn{1}{c|}{$\mathbf{1 9 9 3}$} & \multicolumn{1}{c|}{$\mathbf{1 9 9 4}$} & $\mathbf{1 9 9 5}$ & $\mathbf{1 9 9 6}$ \\
\hline Agricultura, Ganadería, Silvicultura & $3.992,50$ & $3.960,75$ & $3.804,10$ & $3.925,72$ & $4.130,42$ & $4.420,43$ \\
\hline Explotación de Minas y Canteras & 397,43 & 324,74 & 470,13 & 566,42 & 522,12 & 460,33 \\
\hline Industria Manufacturera & $13.943,87$ & $14.719,40$ & $15.065,83$ & $14.361,93$ & $13.909,10$ & $13.255,78$ \\
\hline Electricidad. Gas, Agua & 506,94 & 544,99 & 572,60 & 560,31 & 561,95 & 566,81 \\
\hline Construcción & $2.404,26$ & $2.289,15$ & $3.037,14$ & $1.589,16$ & $1.739,91$ & $2.476,06$ \\
\hline Comercio, Restaurantes, Hoteles & $3.768,55$ & $3.949,24$ & $4.514,65$ & $4.766,51$ & $4.786,96$ & $5.054,21$ \\
\hline Transporte y Comunicaciones & $1.285,44$ & $1.180,61$ & $1.277,97$ & $1.332,18$ & $1.408,14$ & $1.544,64$ \\
\hline $\begin{array}{l}\text { Servicios, Comunitarios, Soc. y } \\
\text { Personales }\end{array}$ & $13.685,23$ & $14.694,43$ & $18.349,84$ & $20.285,54$ & $18.639,20$ & Sin dato \\
\hline $\begin{array}{l}\text { Servicios, Comunitarios, Soc. y } \\
\text { Personales }\end{array}$ & $13.685,23$ & $14.694,43$ & $18.349,84$ & $20.285,54$ & $18.639,20$ & $17.234,43$ \\
\hline $\begin{array}{l}\text { miles de Pesos (\$) a precios constantes } \\
\text { de 1986 Total }\end{array}$ & $\mathbf{4 7 . 4 7 5 , 0 0}$ & $\mathbf{4 9 . 4 8 7 , 0 0}$ & $\mathbf{5 5 . 7 9 4 , 0 0}$ & $\mathbf{5 6 . 5 5 5 , 0 0}$ & $\mathbf{5 5 . 0 7 2 , 0 0}$ & $\mathbf{5 4 . 9 7 3 , 0 0}$ \\
\hline
\end{tabular}

Tabela 4 - Produto bruto geográfico da província de Catamarca. Fonte: Tineo: 2005: 79.

\section{2 - Geomorfologia}

O vale de Santa María faz parte do conjunto conhecido como serras Pampeanas. É uma região geográfica que divide a Argentina, a qual integra uma mesma unidade de primeira magnitude denominada Província Pegmatítica Pampeana. Esta formação está 
constituída por detrito de pegmatítica das classes moscovita e elementos raros, formados no Paleozoico Inferior e no Pré-cambriano Superior (Galliski 1994). Constitui-se em uma extensa depressão tectônica com orientação Sul-Sudoeste e Norte-Nordeste, e estende-se desde a província de Catamarca ao Sul até a Província de Salta, ao Norte. Na formação deste vale, as bordas estão constituídas por rochas metamórficas instruídas por rochas ígneas, as quais afloram nos bloques da serra do Cajón (também conhecida por serra de Quilmes) e nos picos Calchaquíes-Aconquija, ao Leste dessa margem. Nas margens deste rio, observam-se depósitos fluviais com terraços, fruto de erosão (Tineo 2005; Tineo 2004).

Os bordes desse vale constituem-se de rochas ígneas e metamórficas das serras que o delimitam. Estas formações rochosas caracterizam-se pela escassa permeabilidade secundária com um elevado escorrimento superficial, devido à presença de diaclases e fraturas. Esta condição permite o dreno de água dos altos picos, criando a importante rede de riachos e rios temporários. Os movimentos que determinaram a forma como os blocos (que constituem as serras) se encolheram e criaram falhas na cobertura secundária, nesta cobertura secundária predomina uma estrutura monoclinal com um desnível regional em direção à nascente. As formações pleistocênicas estão conformadas sobre o pedimento elaborado que se estrutura sobre as formações miocénicas-pliocénicas do Grupo Santa María (Tineo: 2005: 23).

O Grupo Santa Maria é um complexo sedimentário que aflora na margem direita do vale de Santa María. Esta unidade foi atribuída ao Terciário Superior, provavelmente ao Plioceno A base da coluna que aflora destaca a coloração avermelhada e amarelada característica desta zona. Em cima deste conjunto, encontra-se uma formação arredondada constituída por rochas vulcânicas e embasamento (Mon 1979).

A presença de rochas de distinta natureza e idade caracteriza o vale de Santa María. É possível observar a disposição destas formações no quadro a seguir: 


\begin{tabular}{|c|c|c|c|c|}
\hline \multicolumn{5}{|c|}{ CUADRO ESTRATIGRAFICO DEL VALLE DE SANTA MARIA } \\
\hline & EDAD & & UNIDAD & LITOLOGIA \\
\hline \multirow{4}{*}{\multicolumn{2}{|c|}{ CUATERNARIO }} & \multirow{2}{*}{\multicolumn{2}{|c|}{\begin{tabular}{|l|} 
Q3 Cuarto Nivel-F. Las Mojarras \\
Q2 Tercer Nivel-F. Las Caspichango \\
\end{tabular}}} & Fanglomerado grueso de rocas igneas y metamórficas \\
\hline & & & & Gravas, arenas gruesas y limos \\
\hline & & \multicolumn{2}{|c|}{ Q1 Segundo Nivel-F. Las Salinas } & Conglomerados de rodados metamórficos y volcánicos \\
\hline & & \multicolumn{2}{|c|}{ Q0 Primer Nivel-F. Las Mesadas } & Fanglomerado con rodados metamórficos dominantes \\
\hline \multirow{6}{*}{ 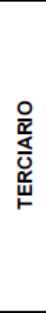 } & \multirow{6}{*}{ MIOCENO-PLIOCENO } & \multirow{6}{*}{ 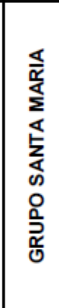 } & F. YASYAMAYO & Pelitas, areniscas, tobas y micritas, castaño-rojiza. Yeso \\
\hline & & & F. CORRAL QUEMADO & Conglomerados de rocas volcánicas, igneas y metamórficas \\
\hline & & & F. ANDALHUALA & Conglomerados finos $y$ arenas medianas \\
\hline & & & F. CHIQUIMIL & Areniscas finas con limolitas y arcilitas \\
\hline & & & F. LAS ARCAS & Altemancia de limolitas y areniscas finas \\
\hline & & & F. SAN JOSE & Areniscas arcillosas, calcáreas, micáceas pardo rojizas \\
\hline & $\begin{array}{l}\text { PALEOZOICO INFERIOR } \\
\text { PRECAMBRICO SUPERIOR }\end{array}$ & \multirow{2}{*}{\multicolumn{2}{|c|}{ Basamento Cristalino }} & \multirow[t]{2}{*}{ Rocas metamórficas e igneas } \\
\hline & & & & \\
\hline \multicolumn{5}{|c|}{ Tomado de Ruiz Huidobro, 1963; Bossi et al., 1982 y Tineo et al. , 1993} \\
\hline
\end{tabular}

Tabela 5 - Estratigrafia do vale de Santa Maria. Fonte: Tineo: 2004: 11

$\mathrm{Na}$ serra do Cajón se reconhecem complexos rochosos de distintos graus metamórficos, desde graduação fina a gnaisse, com intrusões pegmatíticas concordantes com a estrutura geral da serra. Estes complexos são chamados de: Agua de Sapo e Tolombón, ambos limitados pela falha de Chusca (Orientação Noroeste-Sudeste) e na latitude de Colalao del Valle. Na direção Norte, esta falha estende-se pelo Complexo Tolombón. Em direção ao Sul, pelo Complexo Agua de Sapo. Este último constitui-se por uma sequência litológica que varia de xistos de grão fino, e gnaisses de grão fino, ao Sul. Já o Complexo Tolombón apresenta sequências progressivas de metamorfismo de grão médio a grão alto, enquanto a folheação assemelha-se ao Complexo Agua de Sapo (Tineo: 2005: 25).

A serra do Cajón conta com um sistema de falhas inversas ao longo da sua borda, no qual desenvolveram-se importantes depósitos de sedimentos em forma de leques aluviais de idade quaternária, que se constituem de areias e gravas grossas, com grandes rodados de metamórficas. Estes depósitos de sedimentos cobrem o piedemonte da serra e ultrapassam, na sua parte distal, a linha do canal atual do rio Santa María. São fundamentais pois constituem os principais reservatórios de água subterrânea deste vale (Tineo 2004). 
Opostos à serra do Cajón, os picos Calchaquíes indicam solos rochosos de períodos inferiores às rochas metamórficas, idade Ordoviciano para o ciclo eruptivo e Pré-cambriano ao Paleozoico Inferior (Ruiz e Tineo 2004). As rochas que afloram nesses picos são: mica biotítico xisto e/ou moscovíticas, com presença de veios de quartzo; em outros setores da serra, predominam micaxistos injetados, que incluem o pegmatítico rico em feldspato, potássio e mica, sendo que as jazidas de pegmatitos são mais abundantes conforme se desce em direção ao vale (Tineo: 2005: 25).

Resumidamente, é possível representar a formação geológica desta área de estudo em três períodos: 1) Pré-cambriano Superior - Paleozoico Inferior, representado pelas rochas ígneas e metamórficas do embasamento cristalino, que ocupam os núcleos das serras do Cajón e Aconquija; 2) Terciário e/ou Cretáceo, representado por afloramentos somente na borda ocidental das serras do Aconquija e que se constitui de sedimentitas limo-arenosas e limo-argilosas de baixa permeabilidade; 3) Quaternário, representado pelo material aluvial que recheia o vale. Seu desenvolvimento máximo encontra-se nos grandes leques de aluvião de Piedemonte das serras do Cajón e Aconquija e na margem inundada do rio Santa Maria (Tineo: 2005: 29).

A permeabilidade e a capacidade de reserva de água destes solos são baixas, sendo que a zona de maior importância hidrológica seria as planícies de formação do Quaternário, que contam com os reservatórios de águas subterrâneas devido à sua alta permeabilidade (Tineo 2005; Ruiz e Tineo 2004). Como um todo, a região dos vales Calchaquíes apresenta um alto índice de erosão, porém, na área particular do vale de Santa María, existem algumas formações específicas, sendo que a excessiva erosão transformou numerosas estruturas em terras ruins.

De acordo com o levantamento de Tineo (2005) encontram-se as seguintes unidades na área de estudo:

1-) Formas estruturais: encontradas na região de montanha, consistem principalmente em rochas metamórficas deterioradas pela exposição à ação do ambiente. Na zona de montanha, encontra-se o conteúdo da mica, depósitos consolidados e, nos veios de pegmatitos de exploração na superfície, encontram-se também minerais micáceos, turmalina, quartzo e berilo. Na margem direita do rio Santa María, observa-se uma série de depósitos estruturais de estratos finos de areia, arenito e argila, pouco consolidados do Grupo Santa María, que dão origem às terras ruins (bad lands). Material 
talude também foi depositado com frequência sobre estas formações, perceptíveis como grandes formas aplanadas. As bordas das formas estruturais são empinadas e desgastadas, com pendentes de $45^{\circ}$ a $90^{\circ}$.

2-) Leques e taludes de escombros: Esta é uma unidade ativa de material de montanha que é rodado e arrastado pendente abaixo. Consiste em um material misturado (fino e médio), suscetível de erosão. A composição do material do leque varia em seções, na superior, misturam-se rochas angulares e cascalhos $(0,5 \mathrm{~cm}$ a $2 \mathrm{~m})$ dentro de uma matriz arenosa. Na superfície, - encontram-se concentrações de cascalhos que cobrem, da metade até toda a superfície, com partículas finas que foram levadas pela força do vento e da água. Estas rochas provêm diretamente da montanha e consistem-se em rochas metamórficas deterioradas, granitos, quartzo, micas, feldspato e turmalinas. Este solo é chamado "solo de deserto", muitas vezes com a presença de carbonato de cálcio, que une as partículas arenosas. $\mathrm{Na}$ área central, as rochas diminuem em quantidade e a matriz é uma areia fina limosa, às vezes com a presença de húmus.

Esta formação apresenta um importante índice de erosão, criando cavas de até $15 \mathrm{~m}$ de largura e até $5 \mathrm{~m}$ de profundidade. A vegetação consiste em arbustos que aumentam conforme diminui o conteúdo de rochas e cascalhos. Ainda algumas partes podem ser usadas para a agricultura. Ao pé destes leques, o conteúdo de cascalho diminui em quantidade e tamanho, aumenta a presença de areia e se formam pequenas dunas. Quanto mais fina é a textura da areia, mais elas são transportadas e assim os pendentes são mais baixos também (a pendente é determinada pela estabilidade do material). Nessas texturas mais finas, conforme diminui a drenagem interna, forma-se um solo mais próprio para a agricultura

3-) Taludes: São formados por material coluvial com seixos integrados por uma areia grossa. A superfície é plana e apresenta um declive de até $2 \%$. Os taludes são muito parecidos à parte superior dos leques de detritos e todo o sedimento está se movimentando para baixo. Isto acontece porque são antigos leques de detritos, devastados e divididos em partes que cobrem outras formações estruturais ou fluviais e estão divididos por grandes ravinas, por isso movimentam-se a uma menor velocidade.

4-) Terras ruins: São áreas onde a erosão é significativamente ativa, apresentando um movimento do subsolo causado pelo movimento da massa externa. Apresentam-se 
nas bordas das ravinas entre os diferentes taludes e também nos depósitos do terciário superior. Estas terras são quase impróprias para estabelecer agricultura ou construções.

5-) Terraços fluviais: Com pendente nula, raramente apresentam alguma ondulação. Os terraços mais altos (na margem direita do rio) apresentam um alto conteúdo de rochas. Na margem esquerda do rio, os terraços estão formados por areia grossa e argila limosa (com alta concentração de mica) e a drenagem interna varia, no geral coberta por dunas. Os ventos fortes do inverno (direção N-S) levam a areia desses terraços para o leito do rio, que está seco neste período. Os terraços mais baixos que fazem parte da planície aluvial permanecem inundados da época do crescente do rio.

Em Catamarca - como acontece em todas as províncias áridas da Argentina - a formação de rios é alimentada a partir de água de desgelo. Dentro do sistema hídrico de Catamarca, podem-se destacar 4 bacias de maior importância: a bacia com o desague na salina de Pipanaco, a bacia do rio Santa María, a bacia do rio Abaucán-Colorado-Salado e as bacias fechadas da Puna, cursos que se formam com o desgelo mais as águas de épocas estivais. Estas águas inumem-se depois que abandonam a montanha.

\section{3 - Sobre a bacia do rio Santa María}

Santa María e a serra do Cajón formam parte do vale do rio Santa María, uma depressão tectônica que abarca deste Punta Balasto (na Província de Catarmarca) até o Norte de Cafajate (na Província de Salta). A área central deste vale que se desenvolve na Província de Catamarca conta com um importante caule que congrega as águas de desgelo que descem das altas montanhas (Tineo 2004).

A geografia desta região conta com formações montanhosas (as serras do Hombre Muerto, del Chango Real, serras do Cajón e Nevado de Catreal) que se caracterizam por exibir alturas superiores aos 3000m de altitude. A cadeia de serras Vacacorral, Pico Colorado e a Chusca conformam o limite Oeste do departamento de Santa María.

O rio Santa María é o principal coletor desta extensa bacia em forma de ferradura com uma superfície total de $7427,3 \mathrm{~km}^{2}$. Nasce no extremo norte das serras do Cajón com o nome de riacho do Cajón. A longitude aproximada da vertente é de $219 \mathrm{~km}$. A vertente do rio corre em direção Oeste das serras do Cajón até o local identificado como Pie de 
Médano, à altura de Punta de Balasto, onde o seu curso faz um giro, tomando a direção Norte (onde muda de nome para rio Santa María), dirigindo-se à localidade de Santa María. O curso continua e adentra terras da província de Tucumán, passando por Amaicha del Valle e Colalao del Valle seguindo na direção Norte para desembocar no rio Calchaquí na província de Salta (Paoli 2002).

O rio Calchaquí, logo depois de receber o rio Santa María pela margem direita da sua bacia, continua em direção Nordeste para desembocar no Fique Cabra Corral com o nome de rio Guachipas. Posteriormente, passa a ser identificado como rio Juramento ou Salado, até que, por fim, desemboca no rio Paraná (à altura da localidade de Santo Tomé, na província de Santa Fé) pelo qual as águas andinas finalmente alcançam o mar (Paoli 2002). 


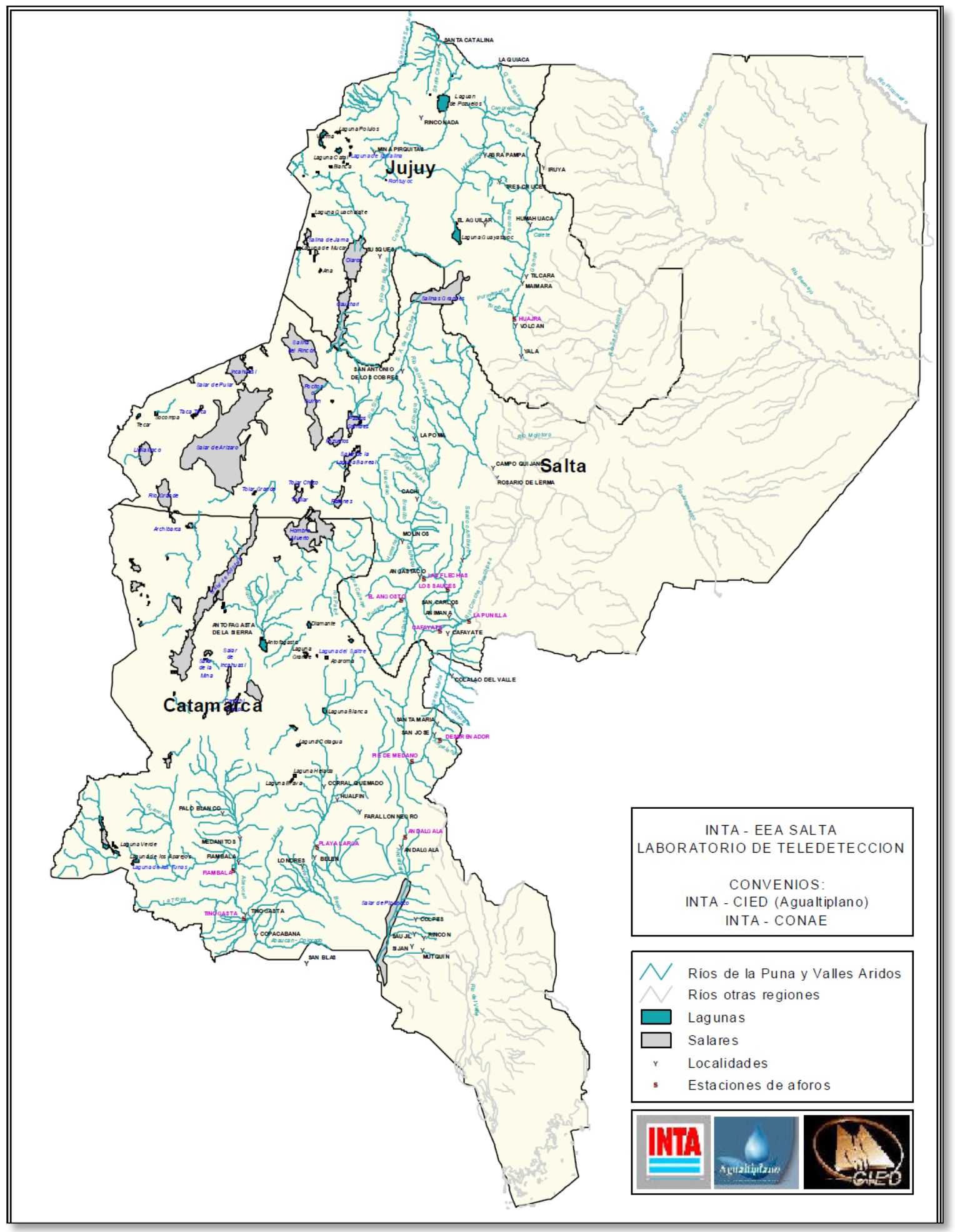

Figura 4 - Mapa indicando a rede hidrográfica das províncias de Jujuy, Salta e Catamarca. Fonte: Paoli: 2002: 146. 


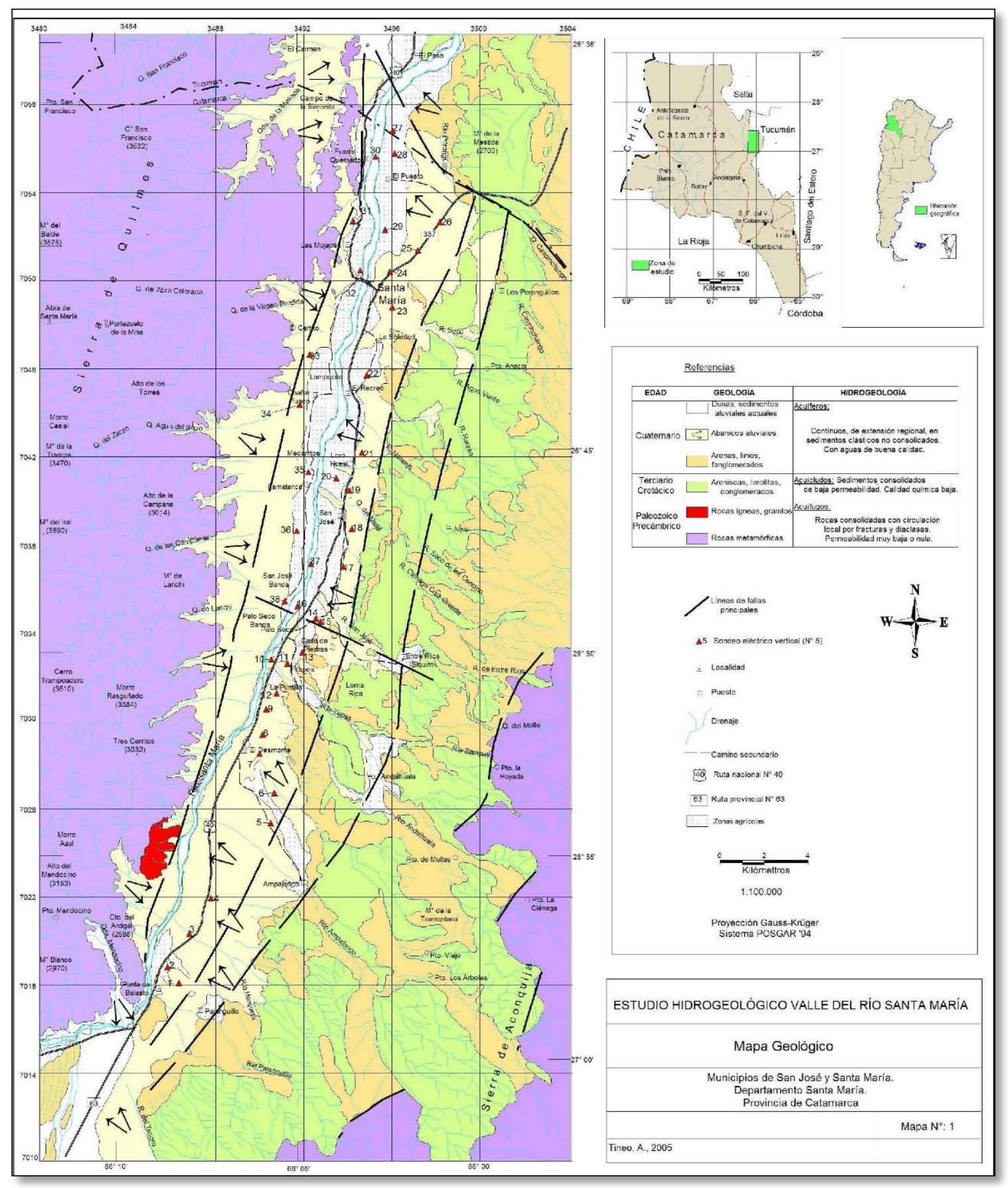

Figura 5 - Mapa indicando a bacia hídrogeológica do rio Santa María. Fonte: Tineo: 2014: 12

O rio Santa María corre em sentido Norte-Sul e é o principal coletor desta área. No seu curso, apresenta um regime permanente até a altura do local chamado Puente de Quilmes. A partir deste local, o rio passa a permanecer seco a maior parte do ano, por causa das infiltrações próprias deste sistema hídrico e do uso intensivo da água para irrigação e rego. Portanto, a bacia deste rio apresenta um déficit hídrico anual, apesar de 
ser considerado um rio que tem água todo o ano. À determinada altura, o caudal extinguese completamente (Tineo 2005). O caudal máximo do rio coincide com o período das chuvas, são as cheias de duração curta que aumentam o nível do rio até a sua desembocadura nas proximidades do rio Calchaquí (Paoli 2002).

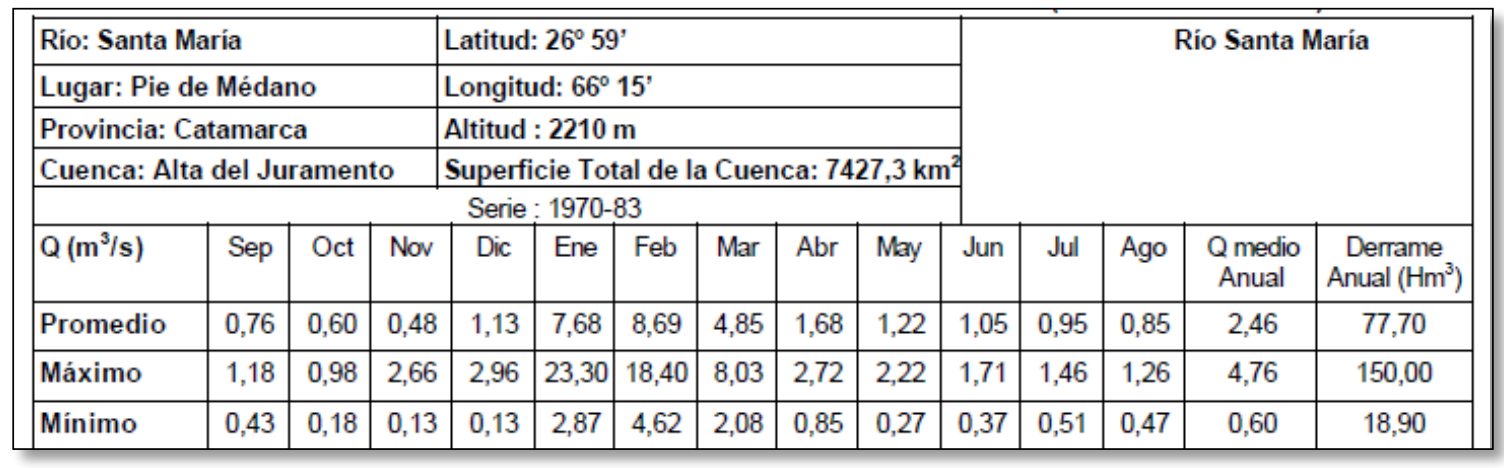

Tabela 6 - Indicativo dos caudais aflorando no pé do médano do rio Santa María. Fonte: Tineo: 2005: 147.

\begin{tabular}{|c|c|c|c|c|}
\hline Río & $\begin{array}{l}\text { Superficie de la } \\
\text { Cuenca en } \mathbf{k m}^{2}\end{array}$ & $\begin{array}{l}\text { Módulo medio en } \\
\mathrm{m}^{3} / \mathrm{s}\end{array}$ & $\begin{array}{l}\text { Caudal específico } \\
\text { en } 1 / \mathbf{s}^{*} \mathrm{~km}^{2}\end{array}$ & $\begin{array}{c}\text { Caudal Mínimo } \\
\text { Medio Anual en } \\
\mathrm{m}^{3} / \mathrm{s}\end{array}$ \\
\hline Santa María & 7.427 & 2,46 & 0,33 & 0,60 \\
\hline Ampajanjo & 144 & 0,340 & 2,36 & 0,32 \\
\hline Amaicha & 182 & 0,370 & 2,03 & Sin datos \\
\hline Managua & 100 & 0,336 & 3,36 & Sin datos \\
\hline
\end{tabular}

Tabela 7 - Indicativo dos parâmetros básicos da bacia do rio Santa María. Fonte: Tineo: 2005: 148.

A bacia do rio Santa Maria recebe água que provém dos poucos afluentes que o alimentam. Em sua trajetória, recebe afluentes da margem direita (ou Leste), provenientes da serra do Aconquija, e da margem esquerda (ou Oeste), da serra do Cajón. A Leste é alimentado pelos rios Pajanguillo, Horqueta, Ampajango, Andalhuala, Yapez, Casa de Piedra, San José, Seco de los Cancianos, Ormechea, Recreo e Pichingallo. São rios de pequeno fluxo hídrico provenientes da zona de piedemonte, que se infla na temporada de chuvas. As águas destes pequenos afluentes chegam à bacia do rio Santa Maria juntamente com um espesso sedimento da idade terciária proveniente do cordão montanhoso do Aconquija (Tineo 2005). 
A Oeste, o rio Santa María conta com uma pequena contribuição de precipitações da serra do Cajón. Em sua maioria, são riachos estacionais de Las Mesadas, da Virgen Perdida, Agua de Sapo e de Lanchi. Esta água de caráter temporário, sendo em maior volume na temporada de chuvas, é praticamente toda utilizada para consumo humano e sistemas de rego. De acordo com as características estruturais do vale, acredita-se que as águas subterrâneas se comportam da mesma maneira que as águas da superfície. Como zonas de melhores aquíferos, destaca-se o rio Santa María em si e a sua porção oriental que corresponde à serra do Cajón (Tineo 2004; 2005).

No mapa a seguir, destaca-se a capacidade subterrânea de retenção de água da zona do distrito de Santa María. 


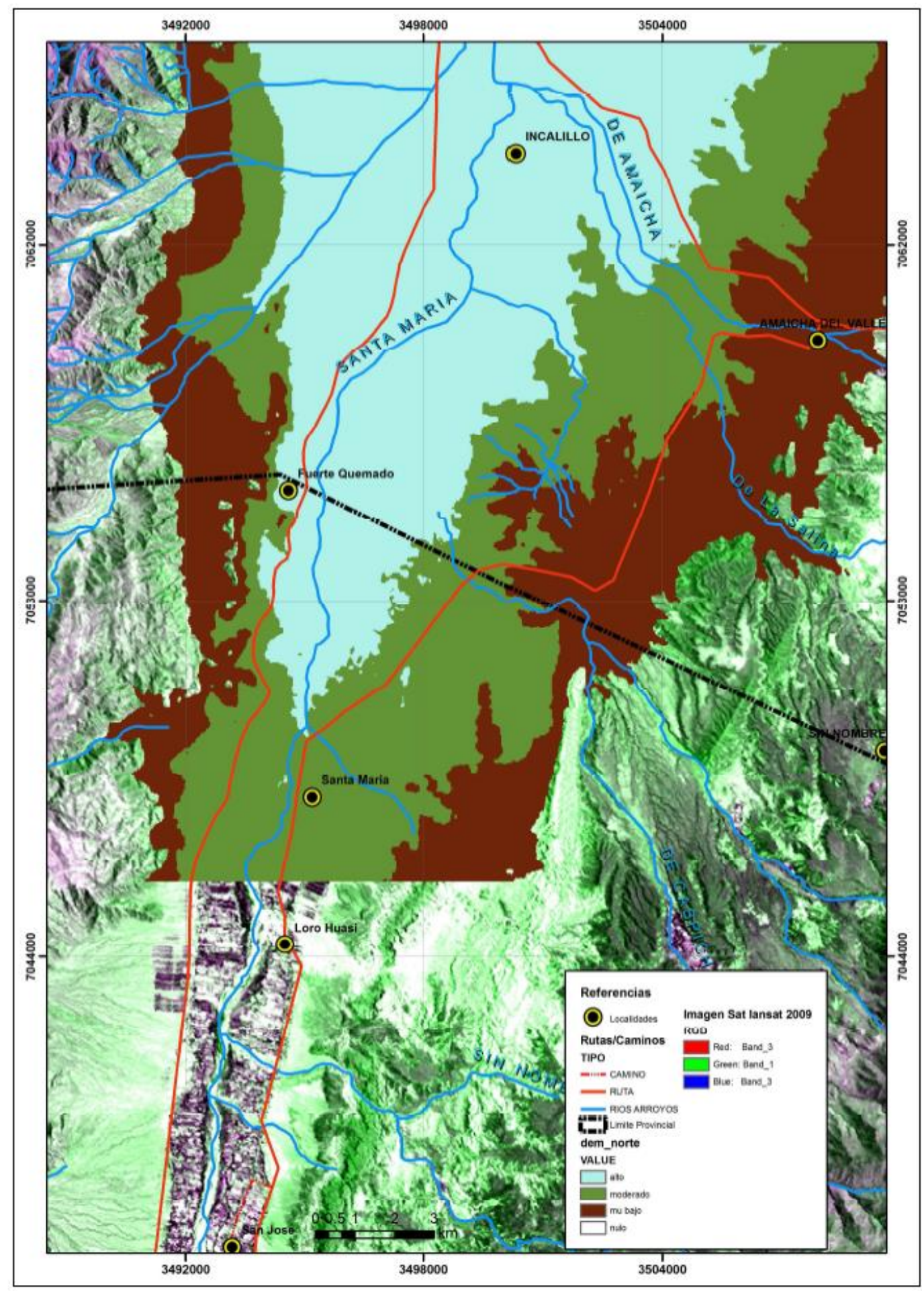

Figura 6 - Mapa indicando o comportamento das águas na bacia do rio Santa María. Fonte: Ruiz e Tineo: 2014: 39

Os cultivos nesta zona estão intrinsecamente ligados à irrigação. A superfície cultivada - de acordo com os dados de 2002, recolhidos por Paoli (2002) - chega aos 2500ha. A pimenta para pimentón e o ají picante representam $60 \%$ da produção, cultivos 
industriais anuais representam 35\%, as forrageiras 30\%, grãos $10 \%$, vinhedos $7 \%$, frutais $7 \%$, hortaliças 7\%, nogueiras 4\%. As planícies naturais e campos de pastoreio representam $32 \%$ e estima-se que $21 \%$ das terras não são aptas para o uso produtivo.

As possibilidades de rego e irrigação em Santa María são limitadas, o regime de água do rio Santa María e seus afluentes não permite planificar a produção agrícola irrigada. A maioria dos distritos de irrigação do vale de Santa María complementa o uso com águas subterrâneas. O sistema de irrigação que se institui inclui turnos alternados e distribuição proporcional por seção de canal e horas de fornecimento por usuário, porém a sua administração depende de uma autoridade denominada "Direção de Riego" e de uma comissão. A zona consta de aproximadamente 60 poços para a irrigação, em 2000 habilitados para bombear água. A Direção de Riego - órgão responsável por administrar o recurso - por meio de um intermediário chamado Intendente de Águas - distribui as águas de acordo com os usos e costumes. Existe uma arrecadação mensal pelo uso da irrigação que, se não for paga corretamente, pode implicar em multas (Paoli: 2002: 149).

As Cooperativas de poços de irrigação administram cobrando pelo uso e horas de águas entregues. Como já não são mais subvencionadas pelo governo estadual, boa parte do montante recolhido é utilizado para o pagamento de luz elétrica (aproximadamente $60 \%$ ), sendo o restante usado para pagar a pessoa que se ocupa de organizar o sistema. Em condições ótimas este sistema funciona, porém, as dificuldades administrativas, a quantidade de integrantes e o roubo de águas implicaram a instalação de comportas e medidas de controle (Paoli: 2002: 149).

\section{4 - Clima}

Para compreender os sistemas climáticos, é importante ter em conta alguns elementos, como as elevações do terreno, a topografia e o relevo. Muitas vezes, estes elementos integrados formam um contexto decisivo para a compreensão dos fenômenos climáticos de uma área e/ou região. Por sua vez, os mecanismos que incidem sobre o ritmo e a distribuição dos elementos são os que indicarão as diferenças significativas como consequência da altitude, da orientação, da topografia, da vegetação e da proximidade ou distanciamento do mar (Flores Moreno e Romero 2013). Considerando as características geomorfológicas já descritas, é importante seguir com a descrição a fim 
de compreender porque, em várias passagens deste trabalho, destaca-se a aridez do clima do vale de Santa María como ordenador de uma série de elementos.

O relevo é um fator de grande importância para se compreender o clima, já que pode modificar as temperaturas, é a causa das diferenças na incidência da radiação solar. No território da província de Catamarca, os elementos meteorológicos sofrem variações criando microclimas devido ao tipo de topografia (planícies, bolsões e cordões montanhosos). Na subida da cordilheira, os cordões montanhosos constituem um verdadeiro limite climático, conservando a umidade em certos vales e privando as massas úmidas de se movimentarem para os vales do interior da serra. Assim, a umidade do ar e a direção dos ventos influenciam tanto na forma e direção (erosão eólica) dos cordões montanhosos, quanto nas características meteorológicas dos seus vales (Flores e Romero 2013).

A grande diversidade de vales e altos picos da cordilheira propicia a existência de diversos microclimas. Considerando tanto as particularidades desta zona quanto o clima regional, é possível confirmar que se está definindo um clima árido de serras e vales, característico destas regiões de cordilheira do Noroeste Argentino, aliado a um contexto regional da Diagonal árida da América do Sul (Flores e Romero 2013). 


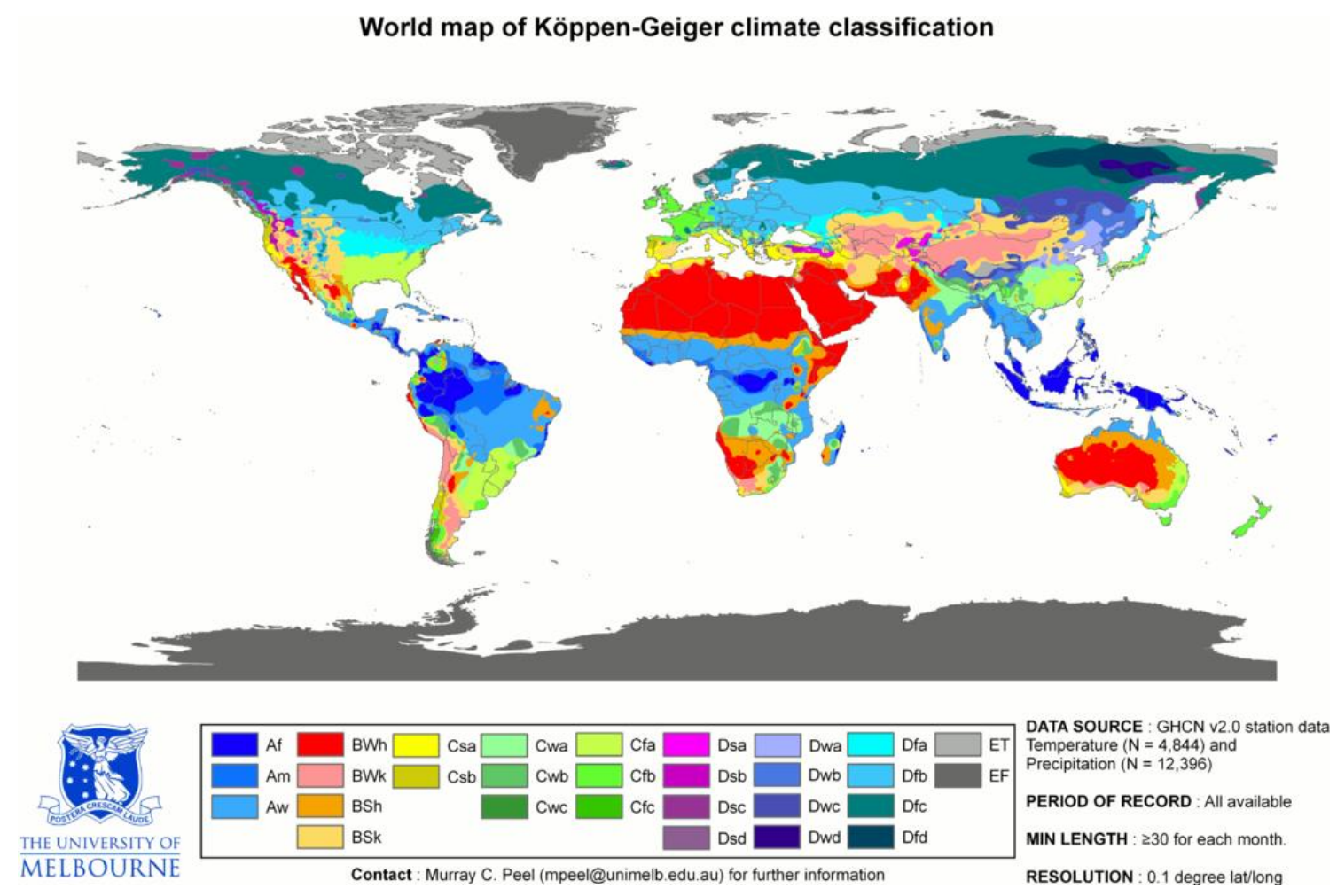

Figura 7 - Mapa mundial da classificação climática de Köppen para o período 1951-2000. Fonte: https://es.wikipedia.org/wiki/Clasificaci\%C3\%B3n_clim\%C3\%A1tica_de_K\%C3\%B6ppen\#/media/File: World_Koppen_Map.png

Considerando a definição de Köppen - que coloca as zonas áridas dentro dos 500mm anuais - podemos incluir esta zona de Catamarca na classificação de clima árido ao semiárido, pela integração de áreas. De acordo com a classificação climática de Köppen, a província de Catamarca corresponde às classificações de estepes, sendo BSSemiárido, de acordo com a porcentagem de precipitações, entre 50\% e $100 \%$ da temperatura média anual multiplicada por 24 , devido à escassa vegetação. E, também, de BSh-Semiárido cálido, devido à temperatura média anual que está acima dos $18^{\circ} \mathrm{C}$ (GIRSU MTLII-SBCC 10/2012). 


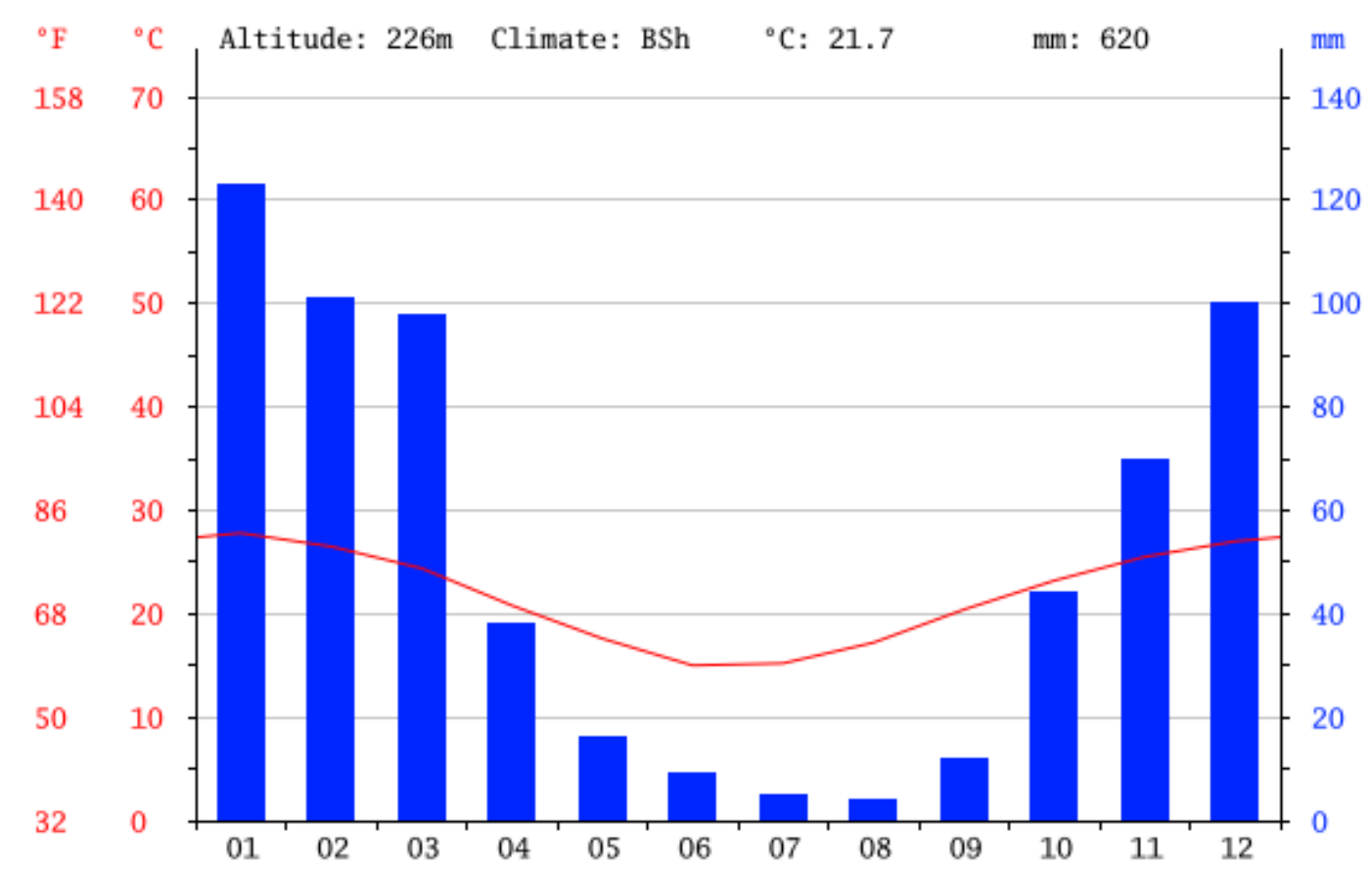

Figura 8 - Gráfico indicando as variações de temperatura de acordo com a altitude ao decorrer do ano em Santa María. O eixo horizontal indica os meses (1-Janiero a 12-Dezembro) e o eixo vertical indica as variações de altitude. Clima. Fonte: http://pt.climate-data.org/location/144809/

Como no AGC, as precipitações mensais variam entre $300 \mathrm{~mm}$ e $600 \mathrm{~mm}$ e algumas classificações consideram esta área como semiárida e outras como árida. Considerando-se as elevadas diferenças mensais e anuais nas precipitações, aliadas a outras variáveis do clima, pode-se considerar que esta zona de Catamarca corresponde à variação de climas de zonas muitos áridas a zonas semiáridas (Vigo 2010).

Desta forma, distinguem-se três categorias climáticas para o território da província de Catamarca:

1-) Clima cálido tropical de serra. Origina-se pelos cordões montanhosos que se estendem em direção Norte/Sul, os quais retém as massas úmidas provenientes do oceano Atlântico, produzindo condensações e precipitações.

2-) Clima árido andino de puna. Com condições severas. As precipitações estimadas não ultrapassam os 100mm e concentram-se nos meses de verão (janeiro, fevereiro e março). A evaporação potencial foi calculada em aproximadamente $570 \mathrm{~mm}$, 
acusando um déficit hídrico para todo o ciclo anual. Conta, ainda, com ventos secos intensos e constantes, aliados à pressão atmosférica baixa e altos níveis de insolação.

3-) Clima árido de serras e bolsões. Corresponde ao sistema das serras Pampeanas. Este clima ocupa a maior parte da província e é caracterizado pela isolamento e distância do mar que provocam variações térmicas com precipitações escassas de 350mm, distribuídas nos meses de novembro a março. Apresenta temperaturas elevadas no verão (chegando aos $40^{\circ} \mathrm{C}$ ) e intenso frio nos períodos de inverno com presença de geadas (GIRSU MTLII-SBCC 10/2012).

$\begin{array}{lrrrrrrrrrrrr}\text { month } & 1 & 2 & 3 & 4 & 5 & 6 & 7 & 8 & 9 & 10 & 11 & 12 \\ \mathrm{~mm} & 123 & 101 & 98 & 38 & 16 & 9 & 5 & 4 & 12 & 44 & 70 & 100 \\ { }^{\circ} \mathrm{C} & 27.8 & 26.5 & 24.4 & 20.8 & 17.6 & 15.0 & 15.2 & 17.2 & 20.4 & 23.2 & 25.5 & 27.0 \\ { }^{\circ} \mathrm{C} \text { (min) } & 20.7 & 19.9 & 17.8 & 14.3 & 11.4 & 9.0 & 7.7 & 9.0 & 12.3 & 15.7 & 18.0 & 19.8 \\ { }^{\circ} \mathrm{C}(\max ) & 34.9 & 33.1 & 31.1 & 27.3 & 23.9 & 21.0 & 22.7 & 25.5 & 28.5 & 30.8 & 33.0 & 34.2 \\ { }^{\circ} \mathrm{F} & 82.0 & 79.7 & 75.9 & 69.4 & 63.7 & 59.0 & 59.4 & 63.0 & 68.7 & 73.8 & 77.9 & 80.6 \\ { }^{\circ} \mathrm{F} \text { (min) } & 69.3 & 67.8 & 64.0 & 57.7 & 52.5 & 48.2 & 45.9 & 48.2 & 54.1 & 60.3 & 64.4 & 67.6 \\ { }^{\circ} \mathrm{F} \text { (max) } & 94.8 & 91.6 & 88.0 & 81.1 & 75.0 & 69.8 & 72.9 & 77.9 & 83.3 & 87.4 & 91.4 & 93.6\end{array}$

Tabela 8 - Tabela climática. Indicando a variações de temperaturas (de maneira numérica) de acordo com os meses do ano, sendo 1-janeiro e 12-dezembro. Fonte: http://pt.climatedata.org/location/144809/ 


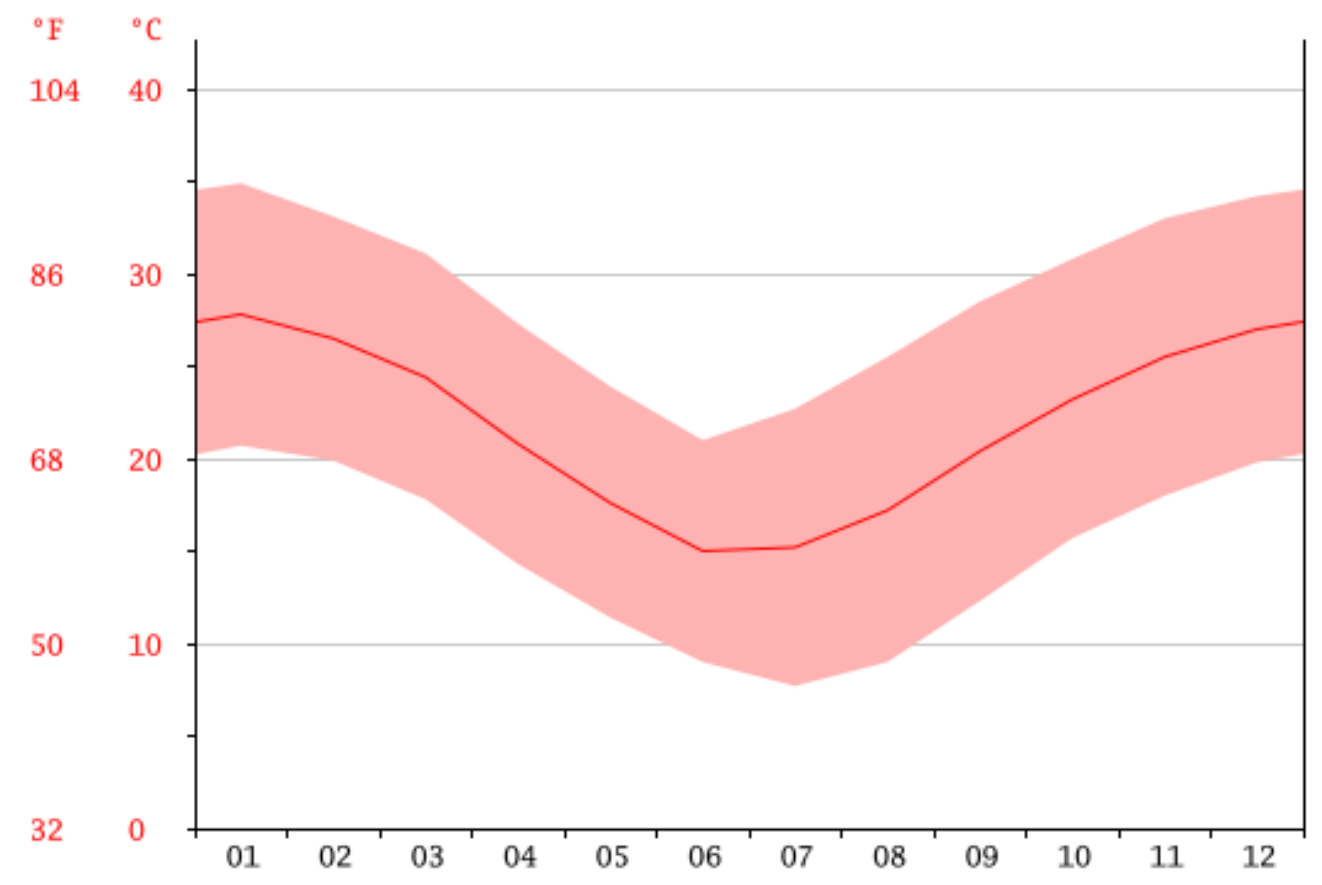

Figura 9 - Gráfico de temperatura, indicando as variações de temperatura que ocorrem em um ciclo anual. $\mathrm{O}$ eixo horizontal a distinção dos meses (1-Janeiro e 12-Dezembro) e o eixo vertical as variações de temperatura. Fonte: http://pt.climate-data.org/location/144809/

As zonas áridas caracterizam-se pela alta variabilidade de precipitações anuais. A vegetação caracteriza-se por ser dispersa, conformada por pastagens (anuais e perenes), plantas herbáceas, arbustos e árvores de pequeno porte. Nas zonas semiáridas, a vegetação compreende uma variedade de pastagens, arbustos e árvores (Vigo 2010). 


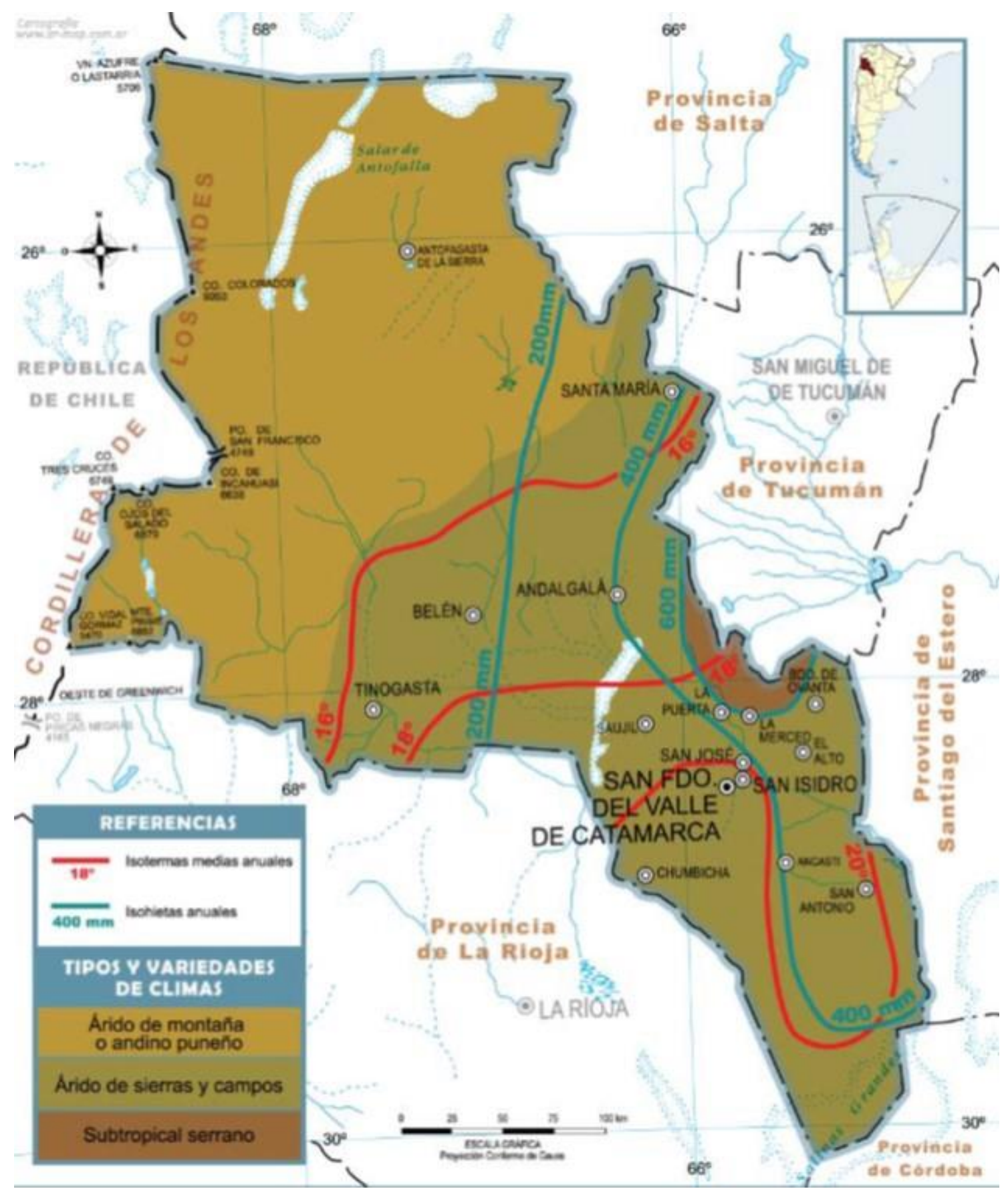

Figura 10 - Mapa indicando os tipos e as variedades dos climas na província de Catamarca. Fonte: HYTSA, GIRSU Catamarca-Primer Informe Versión 2, pg 53.

\section{5 - Fauna e Flora}

O clima, a vegetação e a flora nesta zona de Santa María dividem-se em dois biomas: os vales áridos e a região de Puna. 


\subsection{1 - Vales áridos, bolsões e quebradas}

Apesar das condições da região, existe uma grande diversidade de espécies vegetais representadas pelos grupos botânicos: bosques, estepes arbustivas, gramíneas e vegetação de dunas.

Como unidades de vegetação diferenciada, destacam-se a estepe arbustiva (que cresce num solo arenoso a franco-arenoso) nas margens dos vales até se formar o que se compreende como bosque de alfarroberias, que se estendem por 1 ou 2 quilômetros ao longo das margens dos rios pelo solo limo-arenoso. Porém, esta vegetação não é contínua. Existem setores quase sem vegetação e zonas em que os bosques estão diminuindo por causa do corte indiscriminado. Em seu lugar, cresce um chão de arbustos e matos espinhosos. Nos setores no interior das bacias, encontra-se um conjunto de plantas chamadas jarillal (conhecidas por larreas em português) e, sobre as margens, conjuntos de cardones. Sobre a formação de dunas, predominam as gramíneas e certos tipos de cactáceas (Tineo 2005).

A comunidade arbustiva típica da região de Catamarca é larrea (Larrea divaricata, Larreo cuneifólia, Larrea nítida), que se desenvolve até os 3000m de altitude. As larreas ocupam as planícies baixas, planaltos, colinas, terraços e as bases dos leques de detrito. O solo característico onde estas plantas crescem corresponde a sedimentos finos, arenosos e areno-argilosos. Não toleram conteúdo salino e somente avançam sobre a área de bosques quando este se degrada. Campos de larrea geralmente estão acompanhados de: retamo (Bulnesia retama), brea (Cercidium praecox), palo sebo ou ala de loro (Monttea apphyla), mimosa (Mimosa ephedroides), ursillo (Trichomania usillo), pichanas (Cassia rígida, Cassia aphylla), tala falso (Boungavillea spinosa) e tintitaco (Prosopis torquata).

Em altitudes mais elevadas de até 3200m, para além da comunidade de jarillal, aparecem as espécies que compõem a estepe espinhosa de Piedemonte. São arbustos caducifólios, cactos (várias espécies de Opuntia) e, com bastante frequência, aparecem os cardones (Trichocereus spp). Nas zonas mais baixas, apresentam-se bosques abertos com árvores de folhagem de outras espécies como a tala (Celtis spinosa), o chañar (Geoffroea decorticans), a sombra de toro (Jordina rhombifolia) e arbustos como o atamisque (Cappans atamisquea), a brea (Cercidium praecox), o jume (Suaeda divaricata), o espinillo (Acacia caven), o piquillín (Condalla microphyla) e o chasquiyuyo (Maytenus viscifolia), entre outras. 
Nas margens dos rios, existem bosques de acácias (Acacia visco) acompanhadas das espécies antes citadas. Outro tipo de vegetação, que também acompanha as margens dos rios, é conhecida como "matorrales de los cauces". É uma vegetação arbórea, composta principalmente por cortadera (Cortaderia selloana), junco (Juncus) e chilcha (Baccharis).

Os bosques de alfarroberia seriam os bosques mais importantes da região dos vales, tanto por sua extensão como pelos recursos que oferecem. Atualmente, estes bosques estão diminuindo drasticamente por causa do corte indiscriminado relativo à agricultura de vinhedos em Santa María, principalmente como fonte de energia (lenha e carvão), cercados e infraestrutura para os vinhedos, industrialização da madeira e, ainda, a ação do gado. Os poucos exemplares que permanecem são indivíduos velhos e sem presença renovável (Paoli 2002).

Quanto à fauna, destacam-se alguns mamíferos. Os mais comuns nesta zona são os roedores, algumas raposas, felinos e os voadores. Destacam-se também répteis, alguns grupos de anfíbios e poucas aves.

Entre os exemplares de roedores, destacam-se: tuco-tuco (Ctenomys), cuices (Microcavia, Galea), rata conejo (Reithrodori), ratos (Euneomys), vizcacha de la sierra (Agidium Viscacea) e as chinchillas (Chinchilla), também se destacam os peludos e os quirquinchos (Chaetophractus) e o mataco (Tolypentis matacus). Dentre os répteis, destacam-se espécimes que hibernam, aparecem serpentes (algumas venenosas como a cascavel (Crotalus dmissus terrificus), coral (Micrurus frontalis) e yararas (Bothrops newledí, Bothrops ammodytoides), também aparecem cobras inofensivas (culebras) e tartarugas. Em partes baixas e altas, destaca-se a presença de raposas (Dusicyon, Conepatus chiga, Conepatus castaneus) e felinos que alcançam até as maiores altitudes (Felis colocólo, Felis jacobitd, Felis yagouaroundî) e o puma (Felis concolor), chamado de león, nesta zona (Paoli 2002).

Devido às limitações climáticas, a fauna é muito especializada e, desde a chegada dos espanhóis a esta zona, a ação humana tem contribuído para a diminuição em número de indivíduos e inclusive para o desaparecimento de alguns grupos. As lhamas eram os únicos camelídeos domesticados destes vales. Com a chegada dos espanhóis, foram rapidamente substituídas pelo gado ovino, bovino e caprino. Na área de montanha, vicunhas, guanacos, raposas e chincilas foram perseguidos pelo seu coro e carne, 
colocando estas espécies a beira da extinção, hoje sobrevivendo somente em áreas de reservas. O puma também representa outro problema por sua caça intensa. Os danos que produz ao gado são insignificantes, porém este felino é tradicionalmente considerado uma praga, sendo caçado indiscriminadamente (Paoli 2002).

\subsection{2 - Puna}

As zonas da região de Puna apresentam características bem particulares. A vegetação é muito particular com predominância de gramíneas e matos. Não se encontra vegetação arbórea, os poucos arbustos que aparecem são de pequeno porte. Alguns fatores são indicativos destas particularidades: a) praticamente não se diferencia o inverno do verão, nevadas e geadas podem ocorrer inclusive nos meses estivais; b) os invernos são longos, com ventos fortes e temperaturas muito baixas; c) as precipitações são escassas, o que caracteriza este ambiente como árido e frio (Paoli 2002).

Por causa disto, a vegetação da Puna apresenta uma adaptação especial. As plantas que se adaptaram suportaram todas estas limitações, apresentam um extenso sistema radicular, alta capacidade de armazenamento de água, redução da superfície de folhas (apresentam escamas), proteção nos estômagos, perda de folhagem nas épocas frias e morte das partes aéreas, função fotossintética na casca e nos galhos e talos, troca de folhagem, redução de altura e aumento da densidade da estrutura aérea, formando densos agrupamentos para a proteção do vento e para manter a temperatura interna e umidade no exterior. Nestas regiões de Puna, muitas plantas morrem na época de seca e frio, mantendo órgãos de reserva subterrâneos. É uma estratégia de um grupo de terófitas.

Na região de Puna, as plantas que predominam são herbáceas ou lenhosas e caracterizam-se por uma raiz pivotante única ou raízes em conjunto, das quais saem talos aéreos que se ramificam muito rapidamente, formando um intenso mato de talos que terminam em rosetas ou folhas pequenas esquamiformes. Apresentam-se apresentam num formato semelhante a um tapete. Mesmo quando são famílias de plantas diferentes, apresentam-se de maneira muito semelhante por causa das adaptações ao ambiente. As. associações apresentam característica de estepe arbustiva, estepe arbustiva com graminóides e estepe de graminóides. Estas são abertas e descontínuas, formando conjuntos de matos separados entre si por espaços de solo sem vegetação (Paoli 2002). 
Nos vales da Puna com curso de água e lagoas, aparecem pastos e gramíneas, graminóides e juncos com cobertura de lamaçal. As zonas montanhosas e sub montanhosas, apresentam (em locais bem restritos e sutis) bosques de quinoa (Polylepis tomentella), a única espécie vegetal na Puna que alcança até 4,5m de altura. Porém, esta família de planta tem enfrentado uma regressão significativa ocasionada pelo corte ilegal e abusivo para o seu uso como comestível e nas construções, embora esteja protegida por lei. Estes pequenos bosques de quinoa desenvolvem-se mesmo em solos pouco profundos com alta porção de areia e cantos arredondados. Podem ser observadas outras espécies vegetais, como algumas cactáceas e alguns exemplares de churqui (Prosopis ferox).

Os arbustos que aparecem em áreas mais altas, caracterizam-se pelo nanismo em relação às mesmas espécies de outras zonas. Destacam-se exemplares de Werneria e Azorella. Nas ladeiras de maior altitude e pendentes de solos pedregosos, apresentam-se latifoliadas perenes conhecidas como yareta (Valeriana nivalis, Calycera pulvinata, Senecio aquilaris, Nototrice friesii, Paradiodoxa chiniophylla e Pycnophyllum). Dentre os pastos perenes conhecidos, destacam-se Deyeuxia curvula e Dielsiochloa floribunda (Paoli 2002).

Em ladeiras e pendentes mais suaves de menor altitude, aparece um pasto altoandino aberto. Predominam pastos do gênero Festuca, Deyeuxia, Stipa, Bromus, Poa, entre outros. Nos solos mais úmidos, aparece um pasto anual, a brama (Bouteloa simplex) que cresce juntamente com a Muhlenbergia atacamensis. Também se destacam o trevo da Puna (Trifolium amabile) com Dichondra argentea, Astragalus bustillosii e Astragalus micranthillus, Ipomea minuta (conhecida como culina e tem raízes comestíveis) e a chicória da Puna (Hypochoeris meyeniana). Nas planícies de altura da Puna, destacam-se algumas espécies que compõem estepes arbustiva de tolares, geralmente acompanhada de Baccharis incarum var, Lejía, Acantolippia hastulata (rica-rica), Ephedra breana (pingopingo), Junelia seriphiodes (rosita), Tetraglochin cristatum (canjia), Seneco viridis (mocoraca), Adesmia spinosissima (añagüilla), Parastrephia lepidophyla (tola ou tola vaca) e Artemisia copa (copa-copa). Os melhores campos de pastoreio da Puna apresentam espécies de gramíneas anuais Bouteloa simplex e Aristida humilis, que se alastram sobre campos de estepes arbustivas quando estas se deterioram (Paoli 2002).

As espécies naturais da Puna que são comestíveis para os humanos são de suma importância para complementar a dieta. Destacam-se a quinoa (Chenopodium quinoa), 
que se cultiva cada vez mais em menores extensões, hoje exigindo ajuda de sistemas de rego. Nestas mesmas condições, encontra-se a cañihua (Chenopodium pallidicaule), que é mais resistente à salinidade e aos momentos de sequia que a quinoa. Também existe o coimi (Amaranthus sp), cultivado como verdura fresca e até ornamental. Destacam-se ainda alguns tipos silvestres destas espécies. Estas espécies citadas são consumidas frescas ou cozidas (as folhas e as inflorescências). No caso da quinoa, os grãos são de alto valor nutritivo pela composição de aminoácidos que apresentam, a quinoa deve ser lavada para eliminar as saponinas. Além do uso para a alimentação, as amarantáceas são queimadas e a cinza utilizada para misturar com batatas silvestres (papas runas) e produzir o que se conhece como "yista" (Paoli 2002).

O arbusto conhecido como tola vaca é extraído para combustível, porém, nas suas raízes, encontra-se uma planta parasita (Juelia subterranea) que se consome fresca ou cozida. Na forma de saladas, - utiliza-se romazan (Rumex crispus), berros (Roripa nasturtium-aquatissimus, Mimulus glabratus e Mimulus laceratus), o ataco (Amaranthus vulgatissimus) e a chicória (Hypochaeris meyeniana). Também se consomem os frutos do cardón (Trichocereus pasacana), tubérculos e raízes comestíveis do ají silvestre (Hoffmansegia gracilis e Hoffmansegia tridentatata), do culi-culi (Ipomea minuta) e oca (Oxalis tuberosa) cultivada juntamente com o ulluco (Ullucus tuberosus). As batatas conhecidas como papa runa e papa lisa são cultivadas com ajuda da ação humana, em sítios protegidos e fertilizados com guano de currais e ajuda de rego.

A fauna da região de Puna é rica e variada, justamente pela intensa adaptação que esta zona exige. Tradicionalmente, encontram-se espécies de roedores, de répteis, alguns exemplares de raposas, pumas e condores (quase extintos nos dias atuais) e, entre as espécies de maior porte, destacam-se os camelídeos: guanacos, vicunhas e lhamas.

Nas regiões mais altas, acima dos 3000m encontram-se as vicunhas (Vicugna vicugna). Estes animais possuem uma pelagem que permite manter o calor do corpo e resistir às condições extremas destas altitudes. Nas zonas mais baixas, o guanaco (Lama guanicoe) cuja pelagem é menos tupida, preferindo, portanto, zonas mais baixas e menor intensidade de frio. O guanaco possui uma grande adaptabilidade, por isso colonizou habitats muito diversos, dando preferência a espaços secos e abertos. Adapta-se bem à aridez podendo, inclusive, consumir águas salobres (Paoli 2002). 


\section{6 - Característica humana}

Santa María integra a área regional Puna, da província de Catamarca, juntamente com departamentos de Antofagasta de la Sierra e as comunidades de altura dos departamentos de Santa María, Belén e Tinogasta. Esta zona constitui-se de uma área desértica de altura, vizinha à Cordilheira dos Andes. Apresenta assentamentos dispersos localizados próximos aos locais de maior umidade. A área conserva uma importante paisagem natural e cultural, apresentando espécies autóctones e padrões pré-colombianos de sobrevivência, fundamentados na cosmovisão andina.

Esta cosmovisão dita a dinâmica social, na sua maioria, pois regula processos humanos de apreensão do meio, aumentando a capacidade de sobrevivência e a produtividade dentro de condições naturais hostis. A população desta zona apresenta uma forte identidade e dificuldade de acessar as necessidades da vida moderna urbana (GIRSU MTLII-SBCC 10/2012).

Compreender as particularidades do ponto de vista humano desta zona exige compreender um pouco da história de ocupação local de Santa María.

\section{3 - Breve descrição da ocupação do vale de Santa María}

\section{1 - Primeiros momentos}




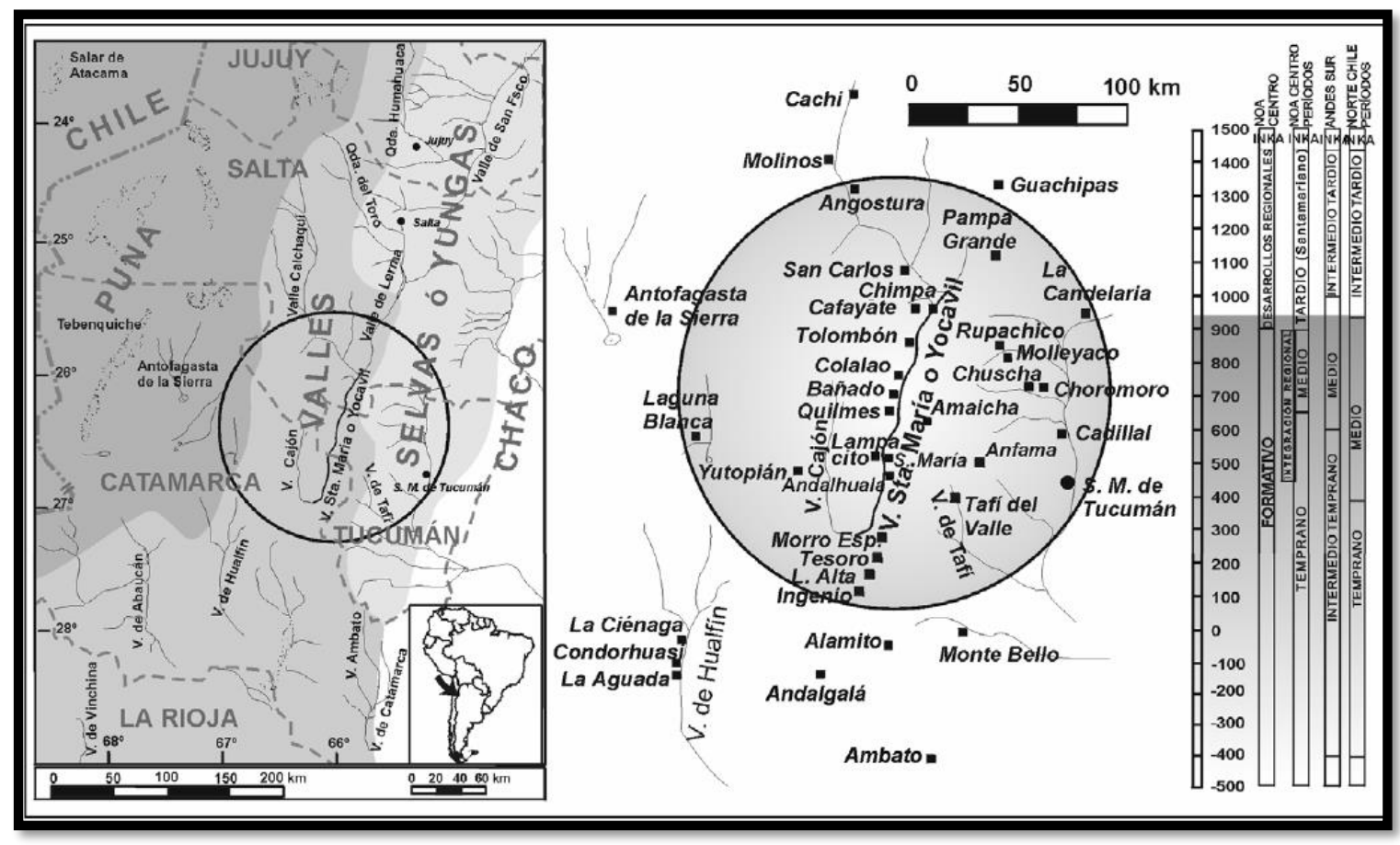

Figura 11 - Mapa do Vale de Santa María, Noroeste Argentino. Elaboração Dr. María Cristina Scattolin. Fonte: Scattolin: 2006: 360.

Os processos de ocupação do Noroeste Argentino respondem, em certa medida, aos processos reconhecidos na área andina no geral, ainda quando podem ser identificadas variações na comparação com a macro área.

Assim, os primeiros registros encontrados indicam a presença de caçadorescoletores, em momentos próximos aos 10.000 AP (Ruiz 1995-6). Para a região do Noroeste Argentino, os primeiros registros de povoamento também coincidem com o fim do Pleistoceno e começo do Holoceno. O tipo de registro sugere uma certa estabilidade no uso dos recursos e do espaço, como o uso e a exploração das matérias primas líticas, a complementariedade funcional de certos sítios e a sua reutilização através do tempo podem estar indicando um provável momento de colonização já iniciada da área. Os sítios destacados encontram-se na região de Puna e, provavelmente, consistiam em acampamentos de verão para a caça, considerando-se uma mobilidade estacional características dos grupos neste período (Aschero 2000).

Posteriormente, observa-se um processo de integração com outras regiões, marcado pela presença de plantas das áreas de vales e selvas de montanha. É provável que as trocas frequentes implicassem na tentativa de obter um excedente ou, ainda, o 
movimento das populações para as áreas com presença de água. Como o clima começa a se tornar mais árido, entre os 7000 e os 5000 AP as ocupações são encontradas mais próximas às áreas dos vales. Neste mesmo momento, ao que parece nesta zona de vales de Catamarca, próximo ao 4500AP, começa o processo da domesticação das lhamas, indicado na presença de restos faunísticos com mais intensidade e seleção de tipo de indivíduo (Aschero 2000).

Porém, o período exato da domesticação - se é que verdadeiramente ocorre como o esperado - não é algo totalmente consensual, é possível que tenha existido um processo de domesticação anterior, próximo ao período de 5300AP. Neste momento, começam a aparecer elementos da costa do Pacífico nos registros dos assentamentos em Catamarca. Isto pode ser um indicativo de prováveis trocas com grupos da costa chilena. Diante de tal condição- e distâncias - para as trocas é possível que as lhamas já estivessem sendo utilizadas como animais de carga. Desta forma, desde momentos muitos iniciais, é possível relacionar os grupos que habitaram os vales do que hoje conhecemos como Catamarca com a dinâmica particular própria do pastoreio de animais (Aschero 2000).

A consolidação dos grupos dentro da economia agropastoril foi possível por um longo processo de conhecimento, manejo e domesticação de plantas e animais que teve lugar durante o primeiro milénio nesta região andina. As primeiras aldeias desta região datam dos séculos X e VI a.C, indicando um estilo de vida que se fundamentou em torno de determinada tecnologia agrícola e o manejo de camelídeos, o qual perdurou mais de 2000 anos. Este modo de vida agropastoril foi possível porque estes grupos adaptaramse às diferentes condições ecológicas, permitindo a sedentarização e a expansão dos mesmos. Assim, desenvolveram tecnologias cerâmicas, tecelagem e metalurgia. Os vestígios materiais recuperados deste período indicam grande complexidade tecnológica, riqueza simbólica e qualidade artística, aliada a um importante fluxo de informação entre os diferentes grupos, o que provavelmente acompanhava a troca de produtos (Albeck 2000).

Esta incrementação e complexidade desenvolvidas pelos grupos, provavelmente deram as bases para o desenvolvimento de sociedades mais populosas e organizadas que ocuparam todo o Noroeste Argentino até a chegada dos espanhóis. A lhama cumpriu um papel fundamental nas sociedades pré-hispânicas do setor andino, tanto como animal de carga como provedora de carne, couro e lã (Albeck 2000). 
O período mais inicial da sedentarização do Noroeste Argentino ainda é pouco conhecido, pois existem poucos dados sistemáticos que remetem a uma seriação e datação sobre estes assentamentos. Especificamente no vale de Santa María, porém, é possível compreender este processo desde uma cronologia mais ampla. Este período é importante para compreender a presença de fenômenos como a sedentarização, a adoção de práticas agrícolas, as manufaturas e a gradual complexidade social dentro do marco da história da região andina (Scattolin 2006).

Neste período do Noroeste Argentino, os vales Calchaquíes foram o cenário de várias sociedades aldeanas ${ }^{5}$. Do mesmo modo que ocorreu em várias outras zonas, este período caracterizou-se pelo desenvolvimento de grupos centrados em povoados estáveis - ou parcialmente estáveis- com as bases de uma economia agrícola de pequena escala e o pastoreio de camelídeos. Pelo que os registros indicam, a organização pode ser considerada igualitária, com baixa diferenciação interna e baixa ou nula centralização (Leoni et al 2012).

Ainda, houve uma grande variabilidade entre estes grupos no que se refere ao padrão de assentamento, práticas culturais e ainda em estilos artísticos na cerâmica, pedra e metal, assim como em questões de aproximação ambiental (Albeck 2000). A definição de sociedades aldeanas se faz por período temporal, indicando que, em todos estes espaços, já havia um domínio agrícola e pastoril até certo ponto difundido, não por unidade cultural.

Desta forma, identificam-se conjuntos de instalações denominados aldeias. Estes conjuntos poderiam ser divididos em dois tipos: instalações dispersas rodeadas por cultivos; e um tipo menos comum que se refere, às instalações agrupadas formando pequenos povoados. Foi dominante neste período a construção em forma circular ou elíptica das habitações, apresentando desde um até vários recintos associados vinculados a um pátio (Albeck 2000).

\footnotetext{
${ }^{5}$ Nome dado ao tipo de assentamento característico deste período.
} 


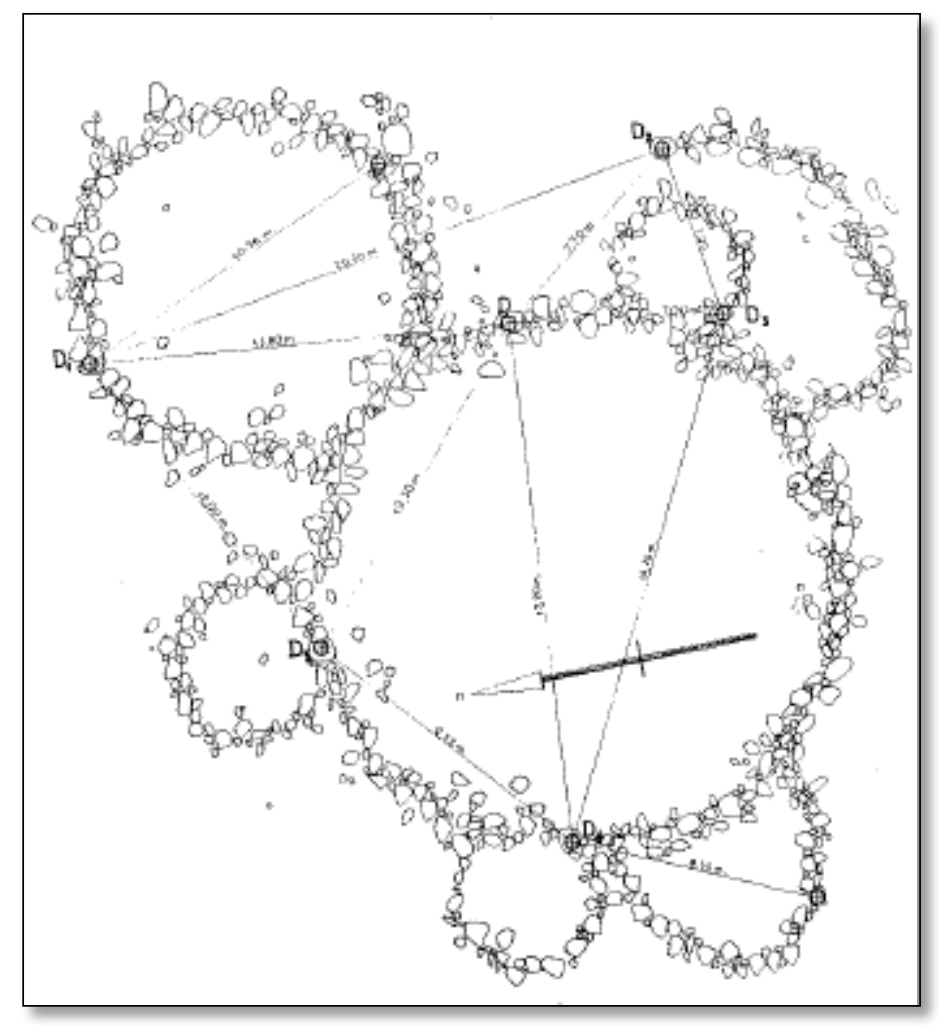

Figura 12 - Plano de um conjunto de habitações em Tafí del Valle, Tucumán. Apresentam formato circular, integradas ao um pátio central. Fonte: Albeck: 2000: 208.

Estas sociedades aldeanas já apresentavam um padrão complementar de ocupação do espaço, onde se integravam as planícies aluviais dos rios até os pisos de serra. É provável que cada unidade doméstica também fosse uma unidade de produção, porém é difícil fazer afirmações concretas sobre este assunto pois as áreas de cultivo estão sendo utilizadas até os dias atuas, dificultando as evidências (Albeck 2000).

As áreas agrícolas ocupavam preferencialmente as áreas de fácil irrigação, por isso a proximidade do rio. A forma mais comum das construções agrícolas associadas são o que se chamam de canchones, áreas de formato retangular - ou mesmo irregulares delimitadas por paredes de pedra. Várias hipóteses são levantadas sobre este estilo de uso do espaço, desde a proteção dos cultivos dos animais de pastoreio até a retenção de recursos hídricos dentro das áreas cultivadas. Estas sociedades tiveram uma economia agropastoril, ainda complementada com a caça e a coleta (Albeck 2000).

As áreas de pastoreio eram compreendidas nos pisos de serra mais elevados com pastagens naturais, onde eram construídos currais. Aparentemente os terrenos de cultivo 
também comportavam pastoreio, talvez em momento onde não havia uma plantação, ou em períodos quando não se praticava a agricultura (Albeck 2000).

Como as casas eram de adobe, ao se desintegrar deram lugar a montículos. Em Antofagasta de la Sierra em Catamarca, um sítio se destaca pela construção de habitações circulares com pisos de argila consolidada, cimento e pedras e paredes cobertas de barro amassado, hoje os restos indicam aproximadamente dez montículos ordenados ao redor de um pátio central deprimido. Esta estrutura está associada a áreas de forragem e campos de cultivo e pastoreio. Estes grupos fizeram uso de um ambiente integrado dos microambientes para assentamento e subsistência. As características dos restos ósseos recuperados dão indício de práticas de charqueado, produção de carne salgada e seca ao sol. Outro local no interior da Puna, numa área de água permanente, também apresenta características bem parecidas, de habitações circulares dispersas e associadas a campos de cultivo irrigados e pastoreio (Escola et al 2013).

A literatura atesta vários registros nestas serras de Catamarca - e todo o Noroeste Argentino - com construções circulares e economia agropastoril. Ao longo de todo o vale de Santa Maria, há evidências de sociedades aldeanas com atividade agropastoril e de magnitudes variadas. A importância do pastoreio destaca-se pela presença constante de currais e proximidade a pastagens, também evidenciada na questão simbólica. No lado oriental do vale de Santa Maria, sobre o declive do Aconquija, encontraram-se vivendas circulares em pedra e silos construídos com lajas e cerâmica, atestando a presença de agricultura (Scattollin et al 2012). Por sua vez, o pastoreio e a sua importância estão inferidos em um achado em contexto mortuário, alguns túmulos apresentando lhamas sacrificadas. Também, destaca-se uma grande riqueza artística entre os achados, com a presença de cerâmica decorada e pintada e a presença de esculturas líticas (morteiros, cachimbos, pratos e máscaras (Rex González 2004).

A residência estável nas aldeias e a economia agropastoril provavelmente permitiram a acumulação de excedentes, assim aparecem as novas tecnologias, como cerâmica, têxteis e metalurgia. O que mais chama atenção é a cerâmica pela sua ubiquidade e grande preservação nos estratos arqueológicos (provavelmente, a cerâmica é um dos elementos que mais chama a atenção em todo o momento de povoamento do Noroeste Argentino e não apenas neste período). As datações mais antigas para a cerâmica nesta região, correspondem a abrigos rochosos e cavernas nos setores mais 
elevados. Em zonas aldeanas, as primeiras datações correspondem ao século VI a.C. (em Las Cuevas) e século V a.C. (em Sanjil), e os assentamentos destes dois casos indicam estabilidade e vida agropastoril plena (Albeck 2000).

Apesar da grande variabilidade cerâmica entre as sociedades aldeanas, há uma recorrência de formas, tratamento de superfície, técnicas e motivos decorativos. A metalurgia é a tecnologia mais complexa que aparece nestas sociedades aldeanas andinas. Esta técnica exigia a presença de grupos produtivos e artesãos com alto grau de treinamento e dedicação. Sobre a tecnologia têxtil pouco se conhece, admite-se o uso do tear, porém pouco persiste nos registros. Sobre a arte e o simbolismo, pouco ainda é inteligível, pois é mínimo o que se pode afirmar sobre a cosmovisão dos diferentes grupos. Porém, o que fica evidente é a existência de aspectos compartilhados entre as sociedades aldeanas, representações recorrentes como os cachimbos e alguns estilos cerâmicos de grande dispersão (Rex González 2004).

Ainda assim, os aspectos compartilhados que ficam evidentes nos produtos cerâmicos, metalúrgicos e líticos falam mais sobre possíveis trocas, sistemas de reciprocidade e integrações entre grupos do que a existência de um estilo dominante ou ainda o furor de considerar um mesmo grupo ocupando uma área tão extensa. $\mathrm{O}$ estilo aqui, pode refletir as distintas situações dentro da sociedade e a sua relação com outras. Os diferentes padrões de assentamento destas sociedades aldeanas refletem as diferentes maneiras de organizar-se.

Neste período, já se identificam redes de intercâmbio, entre elas com circulação de bens, produtos e informações com lhamas (como animal de carga e artigo de troca) e produtos ecológicos de zonas diferentes, já evidenciando a presença de caravanas. As relações entre os grupos também se deram em diferentes escalas. Destacam-se: vínculos de curtas distâncias, entre aldeias do mesmo vale ou de vales próximos; e vínculos de longas distâncias, que englobam a costa do Pacífico e as regiões de selva para além do cordão montanhoso (Albeck 2000).

No decorrer dos séculos, estas sociedades aldeanas estruturaram-se e organizaram-se. Ao que parece, também surgem hierarquias sociais e/ou religiosas (Scattolin 2006). Porém, em questão de organização social, não há um caminho único que se seguiu. Observam-se alguns assentamentos ao estilo das sociedades aldeanas, que permaneceram igualitários até a época da conquista espanhola nestes vales. Outras 
começam a indicar variações de diferenciação social, que provavelmente deram lugar para as organizações de assentamento que aparecem em um período mais tardio (Albeck 2000).

Ao que parece, esta região de Catamarca passa por um momento de mudanças sociopolíticas e econômicas, afirmando a complexidade social com provável presença de relações hierárquicas políticas e de trabalho. Os artefatos cerâmicos que se destacam nestes momentos, ao que tudo indica, são produto de trabalho especializado, que provavelmente está refletindo uma maior estandardização. Entre os registros arqueológicos deste período, destacam-se túmulos e plataformas e o aparecimento de outras obras que não são de caráter doméstico, nas quais está indicada a presença de um estilo cerâmico relativamente complexo (Scattolin 2006).

Definir este momento de mudanças como um período específico tem suscitado uma série de discussões e revisões entre os arqueólogos argentinos. A definição de uma etapa Formativa respondia à necessidade de dispor de um quadro claro e sintético sobre uma periodização do desenvolvimento dos grupos, distribuídos em setores geográficos. Porém, o que define o Formativo é o estilo cerâmico denominado "Aguada" aliado à complexificação das unidades de ocupação e provável estratificação social (Rex González 2004).

Assim, a noção de "Aguada" envolve: incremento populacional (importante densidade dos sítios de habitação, com padrões de instalação mais complexos e heterogêneos); perfil inovador da exploração e manejo dos recursos agrícolas; especialização e estandardização dos bens materiais (particularmente a cerâmica); novas técnicas, materiais e modos construtivos na arquitetura pública e consequente presença de arte mais elaborada, tanto nos objetos como nas construções. A expressão mais marcante é a iconografia centralizada nas imagens de felinos-antropomorfos e figuras fantásticas (o que implica em que também seja conhecido como draconiano) (Gordillo 2010).

Estas características estão presentes em povoamentos dispersos por todo o Noroeste Argentino, porém, ao que tudo indica, este processo começa no início da era cristã, nas proximidades do vale de Ambato, na província de Catamarca. O vale de Ambato apresenta sítios de distinta magnitude e constituem-se em unidades residenciais simples que coexistem com sítios complexos. Todos exibem técnicas e estilos 
construtivos similares, um patrimônio comum de elementos (móveis e detritos), sugerindo ausência de diferenciação em relação ao acesso de alimentos e materiais. A assimetria está indicada na quantidade e no acúmulo que apresentam (Scattolin 2006).

O sítio La Rinconada está organizado pela presença de um pátio central que deve ser acessado para todas as atividades. Os registros destacam a presença de rituais domésticos ou privados, nos quais constam enterramento de lhamas, vicunhas e/ou humanos debaixo das próprias casas para habitação. Apesar de ausentes na decoração cerâmica, os camelídeos estão presentes no cotidiano na alimentação, indicando a persistência de um sistema econômico agropastoril (Gordillo 2010).

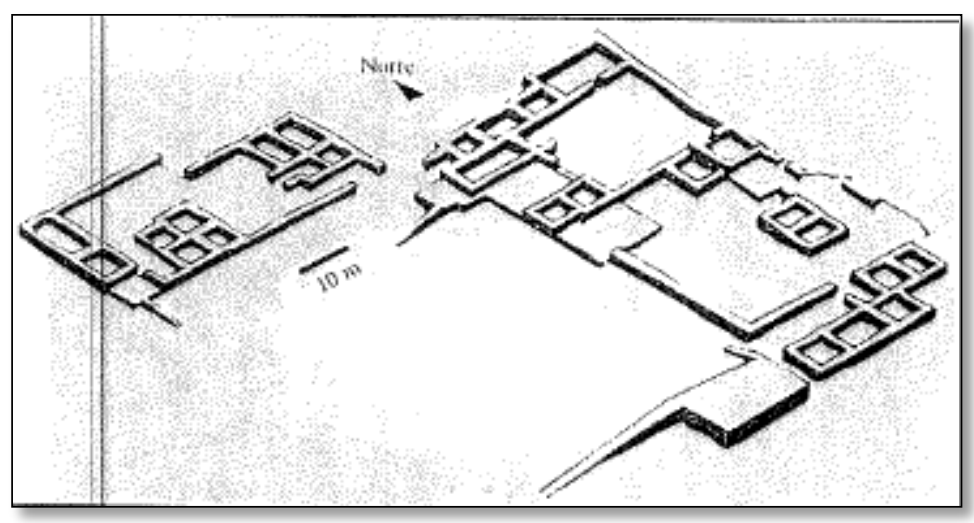

Figura 13 - Representação do centro cerimonial La Rinconada. Vista em perspectiva. Desenho Inés Gordillo. Fonte: Pérez Gollán: 2000 :244.

Os dados acusam que é possível pensar que estes animais foram utilizados de modo integral, para a extração de lã, para transporte, utilização do couro, ingestão da carne e outros subprodutos (Izeta e Scattolin 2006). Registros arqueológicos realizados nas serras de Ambato e La Graciana (província de Catamarca), têm atestado a intensificação do que viria a ser um sistema agropastoril profundamente interrelacionado. Destaca-se uma estreita articulação entre o sistema agrícola e o pastoril de modo a constituir-se em um único sistema integrado - considerando-se uma mesma prática produtiva (e não uma economia mista) -, concluiu-se que tanto o pastoreio como a agricultura estariam utilizando um mesmo espaço e infraestrutura, onde a criação de plantas e animais se beneficiariam e dependeriam um do outro. Entre o que foi observado nos registros, algumas particularidades saltam aos olhos na definição desta relação 
intrínseca entre a cria de plantas e animais de maneira integrada. Destacam-se: as estruturas agrícolas e hidráulicas e currais compartindo um mesmo espaço produtivo; fertilização do solo através do uso de guano; alimentação dos camelídeos com restos de milho; presença de fitólitos de milho em terraços de cultivo próximos a currais (Figueroa 2013).

O processo que sugere o que viria a ser designado o final deste período, supõe um lapso no qual estão implicados processos de integração hierárquica e aparecimento de diferenciação no acesso aos bens materiais e simbólicos. As hipóteses sobre estas trajetórias e mudanças sociais são um dos temas de maior debate na arqueologia argentina.

No transcurso das primeiras sociedades aldeanas às formações posteriores, vários fatores operaram diversos modos de diferenciação, hierarquização do espaço e inversão da paisagem arquitetônica, que influenciavam diretamente nas estratégias sociais, as quais geraram recursos de ordem material e simbólico. Nas evidências, é possível diferenciar algumas áreas de uso cotidiano e setores funerários e rituais, além de modos de diferenciação fundamentados no controle e concentração de recursos, motor das transformações sociais (Scattolin 2006). 


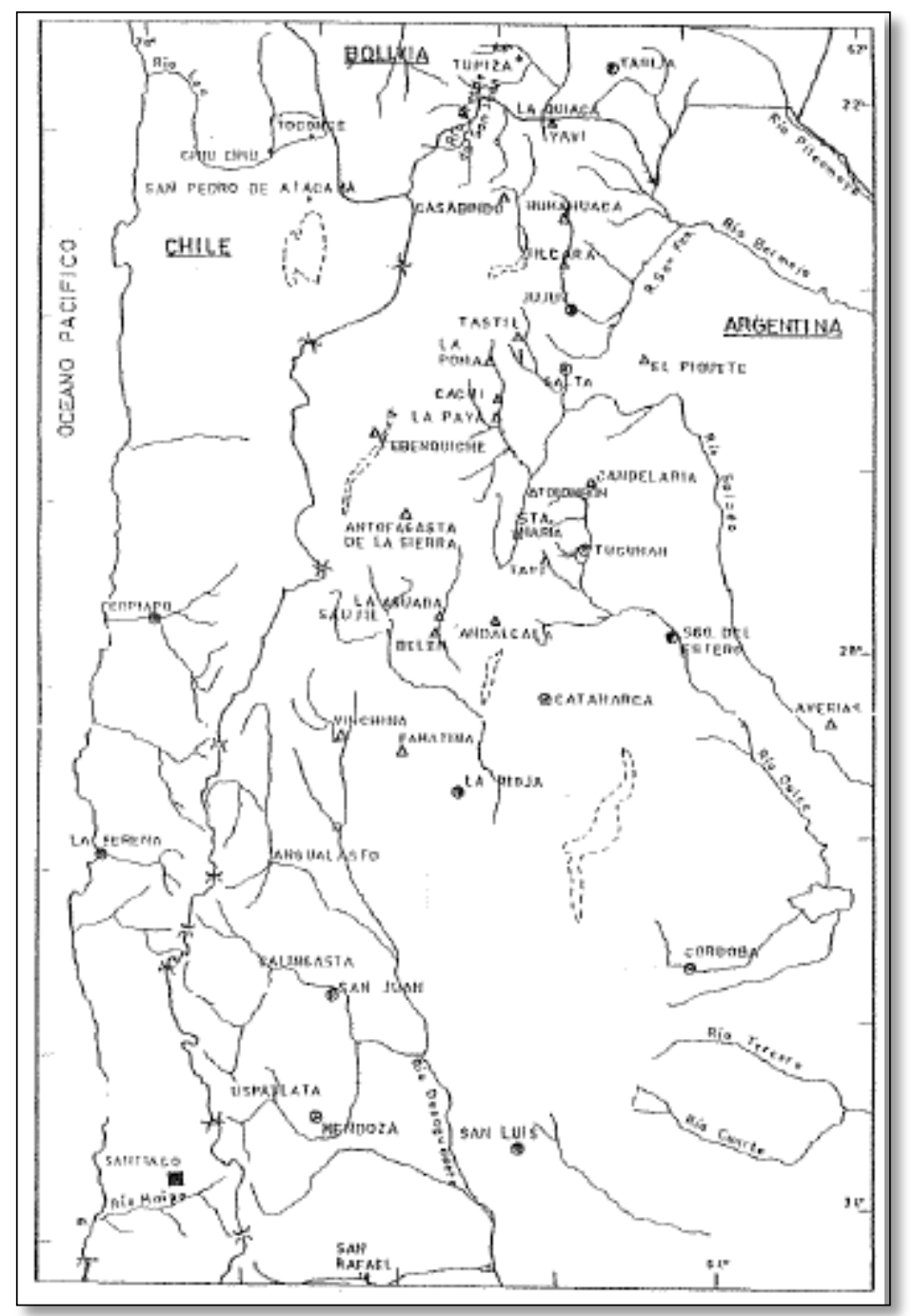

Figura 14 - Região do Noroeste Argentino contendo as comunidades arqueológicas. Fonte: Tarragó: 2000: 262.

Entre os séculos X e XV d.C., o Noroeste Argentino caracteriza-se por um intenso crescimento demográfico e pela aparição de sociedades imponentes com territórios controlados e defendidos. Destacam-se as organizações de: Calchaquí, Tastil, Yocavil e Belén nas províncias de Salta, Tucumán e Catamarca e, mais ao Norte, Tilcara, Humahuaca, Yavi e Casabindo; mais ao Sul: Sanagasta, Aimogasta e Angualasto. Estas novas entidades sociais configuram-se como economias políticas em conflito com aquelas já existentes por pastagens, água e rebanhos (Tarragó 2000).

Os registros materiais deste período atestam o entrelaçamento de avanços tecnológicos (intensificação do manejo nos recursos naturais e de produção) com antigas tradições culturais, indicando fenômenos demográficos, políticos e econômicos. Durante 
este processo, acentuam-se as desigualdades sociais, indicando uma organização do trabalho e distribuição e consumo de bens ainda mais diferenciada do que o observado em momentos anteriores. Quando ao trabalho, instalam-se oficinas de produção de objetos de alto valor social e simbólico que, provavelmente, reforçaram a consolidação de elites (Acuto 2007).

Estes processos sociopolíticos ocorrem em relação a uma intrincada rede de guerras e alianças que precedem o avanço incaico na região. Parecem começar em Haulfín, Shiquimil e Molinos, entre os anos de 850 e 1100 d.C. Sendo que, na metade do século XIII, havia povoados intensamente habitados, sendo que alguns tinham de cem a mil habitantes, ocupando as áreas de Puna e os vales, com exploração agropecuária. Mesmo quando o ambiente mostra um processo de uso do espaço mais controlado, as delimitações não impediram as trocas, mantendo-se ativos os antigos trânsitos regionais e locais (de longas e curtas distâncias) (Wynveldt et al 2013).

Neste momento do Noroeste Argentino, a agricultura hidráulica está plenamente desenvolvida, utilizando-se de terrenos cultiváveis. O desenvolvimento tecnológico alcançado permitiu um aproveitamento maior de diversas áreas, inclusive naquelas mais elevadas das que se utilizam atualmente. Entre alguns sistemas, destaca-se, no vale Calchaquí, Las Pailas, que representou um importante setor agropecuário com centenas de hectares (Tarragó 2000).

Especificamente, no vale de Santa María, outros centros importantes destacavamse em Caspinchango, Huasamayo em El Cajón e Quilmes, que apresentava uma sofisticada represa construída com pedra constando de um canal para derivar a água. Mais ao sul, destacam-se terraços irrigados por canais alimentados com estanques de água (de $6 \mathrm{~km}^{2}$ de extensão). Nas áreas de Puna, a exploração agropecuária foi mais reduzida por causa da menor oferta de água, porém é possível destacar regiões de Yavi e quebrada de Rachaite ou Doncellas, onde existiram instalações agrícolas que cobriam 3000ha, incluídos socalcos e quadros de cultivo (Tarragó 2000).

Entre os cultivos, destacam-se o milho em grande quantidade, batatas, feijões, quinoa e abóbora. Alguns registros indicam a presença de vários tipos de ají e amendoim. Complementarmente coletava-se albarroba e os frutos do chamar para a preparação de tipos de pães doces, arrope (doce de frutas) e bebidas alcoólicas. Estas produções estavam presentes nas grandes peregrinações e festas anuais. O excedente agrícola era guardado 
em silos de vários tipos, construídos com grandes paredões e em locais secos. Provavelmente o milho, as batatas e demais tubérculos eram guardados em buracos no solo e a quinoa em recipientes de cerâmica e sacos. Acredita-se que o direito ao acesso a estes produtos pode ter gerado alianças, assim como conflito entre distintos grupos (Tarragó 2000).

O pastoreio de lhama foi o meio de subsistência básico. Para a manutenção do gado, era preciso dispor de pastagens de altura nas planícies com água ao fundo dos vales. A julgar pelos dados, o aproveitamento dos animais era completo, os restos ósseos indicam a presença na alimentação, nas estruturas dos currais, no uso de fibras para a fabricação de têxteis e em diversos artefatos com couro. Também indicam a presença de ganchos de madeira em quantidade para amarrar as cargas nas lhamas, o que revela um intenso fluxo de caravanas. Ainda neste momento, a criação de animais era complementada com a caça de camelídeos selvagens, veados andinos, além de outros animais, como aves e mamíferos que também devem ter tido importância. Estes estão indicados na iconografia cerâmica, mas talvez não fossem consumidos como alimento. (Tarragó 2000).

A alimentação era variada, valendo-se dos produtos adaptados aos diferentes biomas e do intenso aproveitamento do pastoreio. Ainda quando o registro indica dieta variada, há indícios de diferenças no consumo de proteínas nos distintos grupos sociais. Acredita-se, pela magnitude da infraestrutura agropecuária e dos assentamentos, que sustentaram uma alta densidade demográfica, superando em número e espaços de ocupação, os níveis atuais.

Santa María apresentou grande desenvolvimento, destacando-se 14 núcleos com alta densidade de moradias. Sítios ocupados desde 850 d.C., permaneceram ocupados no período do avanço incaico até 1480 d.C. A maioria está localizada em alturas que variam dos $1500 \mathrm{~m}$ até os $3000 \mathrm{~m}$. A localização corresponde a terraços nas serras ou plataformas naturais, todos locais com ampla visualização da área. Os conglomerados são de extensão variável, porém contínuos e de estrutura complexa, adaptada à irregularidade do terreno. Destaca-se uma série de técnicas construtivas para o melhor aproveitamento do espaço devido à pendente do terreno.

Na parte baixa de Quilmes, observam-se as construções voltadas a um pátio central de aproximadamente $15 \mathrm{~m}$ de diâmetro. O mesmo se observa em Rincón Chico, 
estruturas associadas sempre abertas a um pátio central. Em Loma Rica, abrem-se a vários pátios ao estilo de praças. Os muros são duplos, construídos com lajas colocadas verticalmente em direção ao interior dos recintos. Os muros foram utilizados como calçamento para a circulação pelas unidades. Isto se observa em Quilmes, Rincón Chico, Las Mojarras, Serro Pintado (Magadán 1989).

Em questão de construção, este período destaca-se pelo uso de locais em zonas elevadas, utilizando a parte do fundo do vale. Isto implica diretamente em se pensar em uma mudança estrutural completa considerando-se: a morfologia, o tamanho e a distribuição dos assentamentos.

Um aspecto sobressalente deste período são as construções chamadas pukara ou pucará, que constituem centros residenciais com aspecto defensivo, localizados em cima das serras ou planaltos de difícil acesso e ampla visibilidade. Além de uma visão aberta da paisagem, outra questão fundamental sobre os pucarás é a conexão visual que se tem dos outros no mesmo vale. A rede de pucarás provavelmente reflete a relação existente com a paisagem e com as redes de reciprocidade deste período. Os pucarás mostram-se articulados entre si na paisagem, indicando uma complexa rede de relações econômicas, políticas e simbólicas. Assim como é provável que houvesse disputas pela detenção dos recursos, é possível que as tensões também tenham existido em relação ao acesso às redes de intercâmbio e ao tráfico de bens por meio das caravanas (Tarragó 2011).

Este período foi caracterizado por esses povoados-pukara e também pela diversificação dos bens. A produção cerâmica é um dos elementos que se diversificou, abarcando diversas funções, como a cocção de alimentos, armazenamento, serviços de vasilhas para alimentação e bebidas, vasos rituais e funerários, inclusive para as inumações de crianças (Tarragó 2011).

As sociedades andinas apreendem a paisagem como algo vivo e tudo leva a crer que, neste momento, esta concepção já era vigente. As montanhas e as altas serras exerceram influência sobre as populações, considerando-se que a água que corre das serras é algo sagrado que implica na opção de fertilidade e perpetuação da agricultura. $O$ calendário agrícola previa as épocas de chuvas e crescimento das plantas. Observa-se um vasto conhecimento do movimento dos astros e das mudanças climáticas, inclusive pela presença de um observatório astronômico em um pukara na serra do Cajón (Reynoso 2005). 
Dos rituais, o mais influente é a veneração à Pachamama, que está presente até os dias atuais. O ritual conta com a oferenda de folhas de coca, álcool e outros bens em dias determinados. Há uma profunda relação da Pachamama com a produção da terra e com a liberação das enfermidades. Esta entidade teve tamanha importância que atravessou séculos e expandiu territórios, permanecendo no Noroeste Argentino até os dias atuais como fonte de vida, fertilidade e veneração, e sendo levada pelos Incas a outros extremos dos Andes. No que concerne às religiões andinas e aos rituais de uma perspectiva transandina, considera-se que o funcionamento religioso consistia na veneração do sol e o trovão e as serras desempenham um papel fundamental além de alguns seres animados (camelídeos, felinos, suris, serpentes e batráquios) (Tarragó 2000).

Neste período, os sacrifícios humanos e de animais parecem ser em menor número que em épocas anteriores. Quanto ao uso de substâncias alucinógenas em cultos, os registros também sugerem uma diminuição, porém não o seu desaparecimento, já que registros mostram que, nas oferendas que acompanham as pessoas mumificadas, eram incluídos tubos para aspirar pós e rapé (Tarragó 2000). Os rituais mortuários parecem ter adquirido maior complexidade c neste período. Os adultos eram inumados em câmaras cilíndricas com tampas de tábuas de cardón, acompanhados de parafernálias variadas de acordo com categorias sociais, sexo e idade. Fetos abortados e neonatos eram enterrados em urnas funerárias de reconhecido primor artístico. Estas urnas, conhecidas como as urnas santamarianas, suscitaram a atenção de diversos pesquisadores em diversas épocas (Nastri 2008).

As redes e intercâmbio continuaram vigentes, indicando a permanência de rotas e portos de transação. Ao que parece, os vales Calchaquíes continuaram unidos por um tráfego de bens materiais e simbólicos que, aos poucos, extrapolaram inclusive o próprio vale. Os registros destacam uma importante relação desta zona com outras (incluídas algumas zonas distantes), indicada pela presença da liga de metais estaníferos presente em placas de bronze com elaborados desenhos no estilo presente em Santa Maria. Este tipo específico de liga de metais estaníferos está presente desde o Atacama até territórios como o da atual província de Chubut na Argentina, onde um personagem masculino inumado com um rico acompanhamento funerário destaca-se pela presença de uma placa de bronze da zona de Santa María (Tarragó 2000). 
Na metade do século XV, o avanço incaico penetrou nestas províncias dos Andes Meridionais. Este impacto produziu mudanças significativas no universo material influenciado possivelmente por mudanças sociopolíticas e simbólicas. Porém, o núcleo cultural fundamental e a língua não foram modificados, permanecendo até a época da presença espanhola. Apesar de marginal em relação à capital Cuzco, esta região foi ativa e importante na integração ao Tawantinsuyu e na participação dentro do sistema imperial (Tarragó 2000).

O império Inca estendeu-se pela porção andina do território da atual América do Sul, desde o Equador, até a província de Mendoza na Argentina. O Noroeste Argentino integrava o que vinha a ser o setor sul do império - denominado Kollasuyu - que deve ter sido anexado por volta do ano 1470 d.C. A expansão do império Inca foi possível principalmente pela sua política interna e práticas de distribuição. O sistema imperial Incaico soube adaptar-se com maestria às práticas econômicas locais, sem provocar mudanças radicais nos territórios que dominavam. Para o setor do Kollasuyu, não houve uma grande inversão em questão de infraestrutura, como apresentaram outras áreas, porém a presença do império pode ser identificada pelas diversas estruturas (centros administrativos, tambos, santuários de altura etc.) que mudaram a paisagem em certa medida (Lynch e Páez: 2011: 56-57).

O processo de expansão incaico visava territórios que oferecessem variadas características ambientais, recursos e mão-de-obra. As variações sociais levaram à incrementação de diferentes formas de dominação em cada região. De acordo com a resposta de cada população, eram traçadas as estratégias de ocupação, combinando violência e consentimento junto à dominação. A integração do Noroeste Argentino à organização estatal incaica formalizou-se a partir da criação administrativa de quatro províncias, sendo elas: $1^{\text {a }}$ ) Humahuaca com capital em Tilcara; $2^{a}$ ) Chicoana, com la Playa como centro político no alto dos vales Calchquíes; $3^{\mathrm{a}}$ ) Quire Quire, com capital possivelmente em Tolombón e $4^{\mathrm{a}}$ ) Tamberia de Chilecito, em La Rioja (Lynch e Páez 2011; González 2000). 


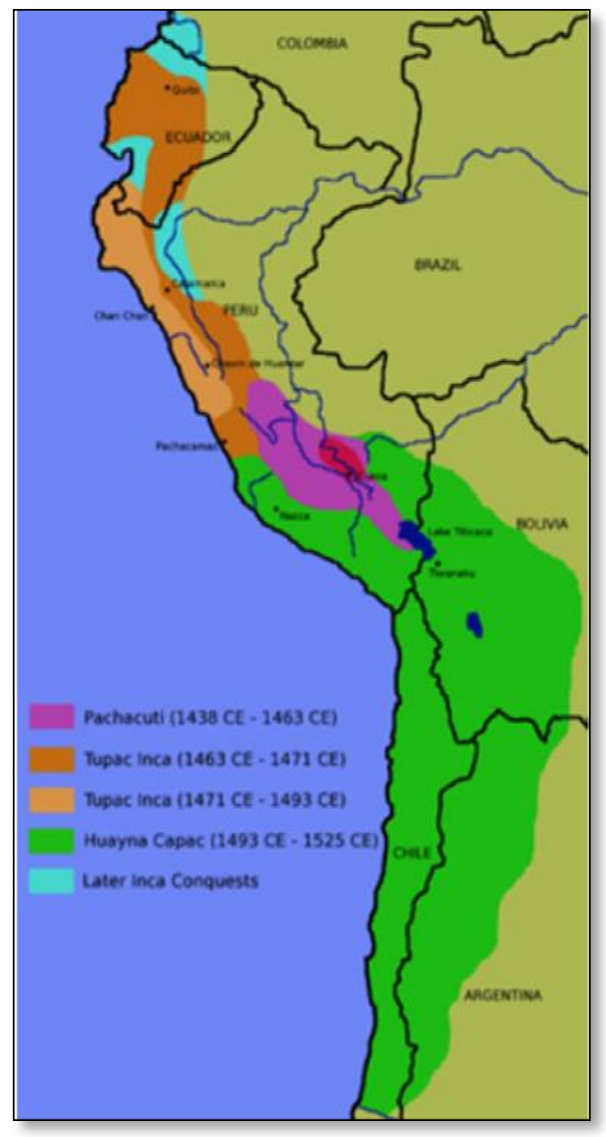

Figura 15 - Mapa representando a expansão do Tawantisuyu. Fonte: Lynch e Páez 2011.

A dinâmica deste grande império dependia do fluxo intenso e rápido de bens, pessoas e informações, do centro para todas as suas partes. Isto levou à construção de uma grande rede de estradas que assegurava a comunicação e o transporte entre todas as regiões. Muitos dos caminhos incas, no Noroeste Argentino, foram ampliações e formalizações de antigos caminhos. Os caminhos incaicos partiam de Cuzco em direção aos quatro suyus (províncias) do império. Conforme crescia a distância de Cuzco, os lugares conectados adquiriam importância de acordo com a posição que ocupavam nesse trajeto. Além de definir espacialmente a importância dos povoados, a rede de estradas também tinha um papel simbólico de omnipresença da autoridade do Inca entre os povos dominados (González 2000).

Os caminhos incaicos variaram de acordo com a importância da região para o império. Assim, cada conjunto de caminhos varia em dimensões e cuidados construtivos. Dependendo do terreno, apenas se delineavam os limites, outros apresentavam muros baixos nas bordas ou até paredes quando estes atravessavam ladeiras ou cultivos. Alguns 
lugares apresentavam pavimento com lajas e pedras lisas de rio. No Noroeste Argentino, a rede viária alcançou aproximadamente $2000 \mathrm{~km}$, com orientação Norte-Sul. Apresentava caminhos transversais que saiam do tronco principal e acessavam os locais. A estrada principal percorria as terras de Puna, chamada de "caminho de serra", acessava os vales Calchaquíes pela Abra de Acay (limite das províncias e Tucumán e Salta) e seguia por um traçado similar ao que atualmente é a estrada Nacional $\mathrm{N}^{\circ} 40$, atravessava as províncias argentinas de Tucumán, Salta e Catamarca e virava no sentido Oeste, atravessando as cordilheiras até o Chile (González 2000).

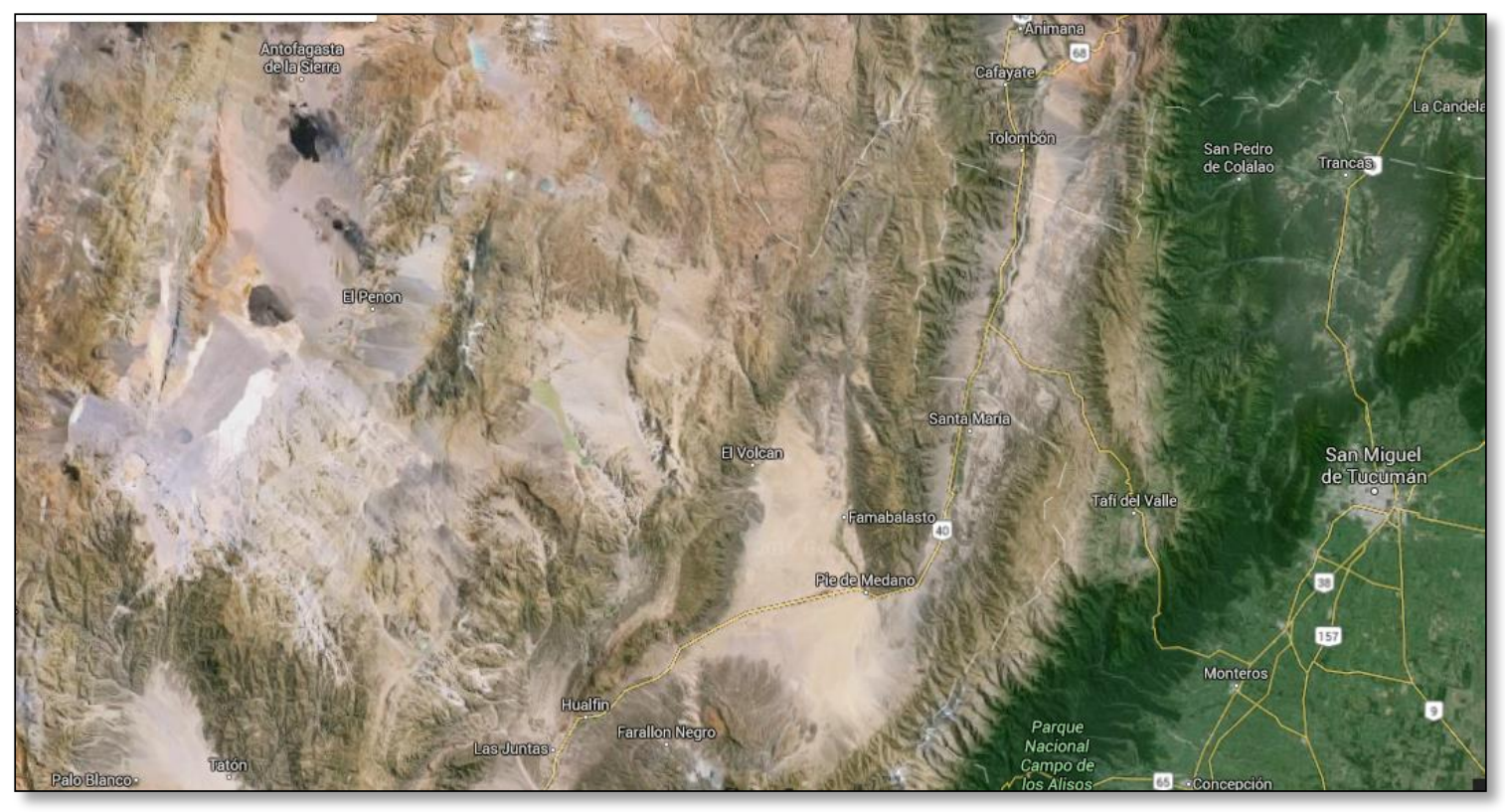

Figura 16 - Mapa da vista do vale de Santa María atravessado pela estrada Nacional No40.

No percurso desta rede, instalaram-se tambos (locais de amparo para viajantes, caravanas, correio etc.), pukaras defensivos, locais administrativos e chaskiwasi (vinculados ao correio imperial). O ritmo da viagem era marcado pela distância ente os tambos (de 15 a $25 \mathrm{~km})$, mas também existiam instalações menores, mais próximas $(12 \mathrm{~km}$ entre uma e outra). No percurso desta rede de vias, os povoados que atravessava foram remodelados e modificados, como exemplo cita-se Fuerte Quemado (hoje distrito de Santa María) cuja parte baixa que encosta na estrada foi associada ao caminho imperial (González 2000). 
Em questão arquitetônica, houve grande variabilidade, porém foi difundido pelo território um conjunto de elementos arquitetônicos que contribuíram para afirmar o poder imperial nas colônias. Por um lado, os caminhos facilitaram a dominação, por outro, o rápido fluxo de produtos e mão-de-obra. Assim, o poder estatal abrangeu diversos aspectos da vida dos vales Calchaquíes, produzindo e reproduzindo contextos, ainda nas colônias mais distantes como a destes vales. Decidia-se o que produzir e como fazê-lo, o uso dos produtos e os destinos. Os vales Calchaquíes continuaram com a produção agropastoril, que tanto havia sido incrementada e produtiva. O poder estatal somente modificou algumas concepções espaciais para facilitar o escoamento dessa produção. Os currais, em sua maioria, não divergiram em questões construtivas, foi dada preferência à proximidade das estradas (González e Tarragó 2004).

Ao que tudo leva a crer, a integração do Noroeste Argentino aconteceu por interesses econômicos de absorver a produção local. As mudanças mais significativas que integravam alguns centros cerimoniais, locais de controle estatal e influência na produção cerâmica e metalúrgica - não indicam diretamente uma condição de reiterada resistência, mas uma adequação à nova ordem, aliada à busca por manter e reafirmar a sua própria condição social e simbólica. A integração destas populações ao império Inca foi um processo lento, portanto não postula grandes mudanças quanto aos sistemas produtivos nos vales Calchaquíes. Principalmente no que concerne às pequenas comunidades no interior dos vales mais distantes do poder centralizador. Isto também aconteceu em um primeiro momento do avanço espanhol (González e Tarragó 2004).

As primeiras expedições europeias surgiram desde o atual Peru pela própria rede viária que o império Inca havia construído para acessar as suas colônias. Acredita-se que a resistência ao império Inca nunca deixou de existir e, provavelmente, o mesmo senso de coesão e resistência foi utilizado para fazer frente à dominação espanhola por tanto tempo. As comunidades indígenas destes vales viram-se, durante muitos anos, obrigadas a articular novas formas com as sociedades dominantes (González 2000).

\section{2 - Sobre o período Colonial}

Desde os primeiros contatos com os espanhóis, os índios dos vales Calchaquíes começaram um processo de resistência e rebelião, o qual se prolongou por mais de um 
século. A penetração dos europeus nos vales Calchaquíes foi muito peculiar, nas províncias de Tucumán e de Salta, os espanhóis encontraram-se com populações muito diferentes daquelas com as quais já tinham travado disputas em outras regiões.

No momento da chegada do espanhol, a população dos vales Calchaquíes - com várias organizações políticas independentes antes do avanço incaico - encontrava-se fragmentada e com certa experiência em fazer frente a um poder invasor. Os espanhóis depararam-se com comunidades complexas e bem organizadas, o que possivelmente dificultou a tomada do território e, nessa primeira etapa colonial, estes grupos conservaram a sua autonomia e inclusive participaram das atividades econômicas, principalmente voltadas à criação de gado. $\mathrm{O}$ intento de criar encomiendas, dividir a população e impeli-la aos trabalhos forçados foi enfrentada com grande resistência neste vale (Boixadós 2011).

Num primeiro momento, a frente de resistência das populações dos vales Calchaquíes, aliada ao isolamento em relação às rotas mercantis e aos assentamentos no alto das serras, propiciou um sistema de exploração mais disperso sobre esta população nativa. Na segunda metade do século XVI, os espanhóis já haviam dominado toda a região do Noroeste Argentino, da atual província de Jujuy até a atual província de La Rioja, porém os vales Calchaquíes continuavam gerando disputas e dificuldades para o avanço Colonial (Faberman e Boixadós 2006).

O processo de dominação destes vales perdurou por aproximadamente 130 anos de resistência indígena frente ao invasor europeu. As populações locais apelaram a diversas estratégias para resistir e enfrentar o avanço da coroa espanhola sobre o seu território. Este processo é conhecido como as Guerras Calchaquíes e desenvolveu-se em três etapas fundamentais, florescendo uma série de histórias e personagens icônicos (e reais) tanto do lado indígena, como do lado dos europeus (Rodríguez 2008).

As primeiras disputam datam de 1562, com o avanço indígena, fazendo que os espanhóis recuassem e arrasassem as cidades já instaladas, expulsando os espanhóis da área e perdendo as terras já conquistadas. Em 1635, os grupos indígenas do setor médio e sul dos vales Calchaquíes (entre aqueles que ainda resistiam destacam-se alguns como gualfingastas, sichagastas, taquigastas, bombolanes, anguingastas, ampascachas, tolombones, pacciocas e colalaos no setor médio e, no setor sul, estavam quilmes, yocaviles, anguinahaos, tocpos, anchapas, tucumangastas e ingamanas) haviam chegado 
a um tipo de acordo com as autoridades coloniais, pelo qual os indígenas se comprometiam a cumprir certas prestações em troca de permanecer nas terras. Graças a esta resistência, muitos destes grupos conseguiram negociar melhores condições para as desnaturalizações, onde ainda desterrados, porém mantendo-se unidos, com a possibilidade de reproduzir as mesmas condições comunitárias (Boixadós 2011).

O segundo momento reflete um processo de exaltação das partes, quando os espanhóis conseguem acessar o vale, não tendo ainda pacificado os indígenas. No terceiro momento, empreendem-se duas campanhas ofensivas, nas quais, finalmente, os espanhóis saem vitoriosos (ver Boixadós 2011; Rodríguez 2008).

Sobre as alianças que os indígenas dos vales Calchaquíes fizeram para enfrentar os espanhóis, o pouco que se sabe indica que constituíam relações temporais para enfrentar um problema comum. No âmbito destes vales, as relações variavam entre alianças e antagonismos, conflitos que tomaram dimensão e foram utilizados pelos europeus para desestruturar e avançar sobre as terras do vale ainda indígena (Palermo e Boixadós 1991).

Um informe realizado no ano 1662, ainda indica a presença indígena na região, porém, pouco tempo depois, campanhas para finalizar a conquista estão em andamento. A primeira etapa dessa campanha tem lugar por volta de 1665 , quando se concretiza o projeto de desnaturalizações da população do vale Calchaquí que havia sido recentemente vencida nos últimos enfrentamentos belicosos entre indígenas e a frente europeia na zona. Diante disto, a coroa espanhola considera o fim do "problema Calchaquí", representando o grande trunfo dos espanhóis sobre os indígenas (Boixadós 2011).

Com a conclusão desta última campanha ofensiva, entre os anos de 1664 e 1666, veio uma nova etapa para estes vales e a população que residia ali. Uma vez vencidos, os grupos indígenas dos vales Calchaquíes foram desnaturalizados e transladados massivamente a outros territórios distantes. As desnaturalizações foram a ferramenta de domínio mais utilizada entre os espanhóis nestas zonas da atual Argentina. O processo significa o abandono forçado do seu "natural", o desarraigamento das terras ancestrais e a remoção forçada a outras regiões distantes daquela de origem. $\mathrm{O}$ translado massivo também implicava no desmembramento de um povo como comunidade, sendo que os integrantes eram separados e distribuídos para várias regiões do domínio da coroa espanhola (Palermo e Boixadós 1991). 
Dos vários grupos que resistiram até o final do processo das Guerras Calchaquíes, muitos foram entregues a encomiendas e divididos em dois ou mais grupos. Um primeiro momento de desnaturalizações começou em 1659, finalizando a primeira campanha ofensiva, com triunfo europeu sobre os indígenas. A segunda, que aconteceu até 1664, correspondeu aos grupos do setor sul do vale, últimos que resistiram; eram quilmes, yocaviles, ingmanaas e tucumangastasos separados em duas ou três famílias (Palermo e Boixadós 1991).

Dos diversos casos de desnaturalizações, o mais ilustrativo e do conhecimento geral é o dos quilmes. Em 1666, famílias indígenas deste grupo - vizinhas daqueles que habitavam o que hoje é considerado o distrito de Santa María - foram transferidas forçosamente até a cidade de Buenos Aires. Com o decorrer dos anos, a redução à qual foram levados deu origem ao que hoje se conhece como a cidade de Quilmes, localizada sobre o rio de La Plata a $21 \mathrm{~km}$ da Capital Federal Buenos Aires (Palermo e Boixadós 1991).

No geral, os grupos de desnaturalizados não foram a regiões tão distantes como essas famílias quilmes. Os relatos indicam que foram a encomiendas em jurisdições na Governação de Tucumán, em La Rioja, em Córdoba e no vale de Catamarca. O plano do governo com as desnaturalizações ia além dos castigos por resistência e belicosidade dos indígenas dos vales Calchaquíes. Também previa liberar territórios e prover mão-de-obra em alguns locais que consideravam necessitados, principalmente aquelas províncias que tinham contribuído com dinheiro para estas campanhas ofensivas, como era o caso do governador de Buenos Aires (Palermo e Boixadós 1991).

Os traslados massivos obrigaram os indígenas a conviver com alguns grupos originários. Isto foi fruto de conflitos entre indígenas (além daqueles entre indígenas e o colonizador). Se o mapa étnico já havia sido alterado com o avanço incaico, agora, com o domínio espanhol, mudava com ainda mais intensidade e rapidez. Por sua vez, as péssimas condições além das sucessivas guerras tinham reduzido a população a número considerável. Porém, este processo era maior do que foi considerado durante um tempo pela história, longe do desaparecimento indígena observou-se uma tendência inversa, os grupos persistentes fundiram-se, agregaram-se em unidades mais ou menos consistente e recriar uma condição comunal (Faberan e Boixadós 2006). 
As desnaturalizações promoveram um grande paradoxo. Se por um lado, as terras do vale estavam "livres" para serem utilizadas pelo elemento europeu, por outro, indígenas estavam trabalhando essa terra e, consequentemente, também a ocupavam. Registros do período sugerem a existência de grande número indígena na zona, o que indica que, mesmo que os indígenas tivessem sido proibidos de retornar ao vale no momento pós conquista, algumas famílias desterradas retornaram aos antigos locais. Embora quando o retorno fosse voluntário, impulsionado por fugas, ou ainda porque os novos proprietários das terras os estavam trazendo para trabalhar nas propriedades e servir de mão-de-obra, os antigos habitantes destes vales somaram-se a outros grupos indígenas provenientes de outras zonas (Rodríguez 2008).

Diante desta situação, coloca-se a proposta de que estes vales, longe de terem sido "esvaziados" de indígenas, apresentaram uma mudança, porém os índios continuaram existindo de forma modesta. Associaram-se e recriaram uma vida comunitária (ainda quando muito diferente e distante daquela já vivida antes do domínio espanhol). Os grupos desnaturalizados aprenderam com aqueles locais os recursos e o meio de subsistir nas determinadas zonas. A maneira como ocorreram as migrações para o vale de Santa María pode elucidar estas questões da presença indígena no vale, pós desnaturalizações. Alguns trabalhos levantaram a importância de Santa María, no sentido do uso de pequenas propriedades no interior do vale e no alto das serras - principalmente em vales altos como o vale do Cajón - para a produção pecuária com diferentes animais (Rodríguez 2008).

Durante o Período Colonial, a presença do pastoreio também é identificada no vale. Rodriguez (2008) atesta a existência de rotas de gado entre a província de Córdoba e a província de Salta. Os vales Calchaquíes, neste momento destacaram-se como local de invernada e como rota que unia a produção de gado e os seus derivados. A diferença do que aconteceu no norte do vale Calchaquí, em Santa María, é a presença de pequenas propriedades de produção de gado associada a outros produtos. Apesar de que a informação se limita mais a rotas coloniais, é possível confirmar a existência de propriedades voltadas à produção de gado, inclusive a serra do Cajón.

Posteriormente, já no século XX, o trabalho de Sanz de Arechaga (1948) destaca que, até meandros de 1940, a população no vale de Santa María e na Serra do Cajón era relativamente numerosa e encontrava-se dispersa no interior da serra, levando uma vida de transumância, sendo que a atividade principal era o pastoreio. A autora faz um estudo 
aprofundado sobre os hábitos pastoris e territoriais nestas serras. Destaca que o território de cada pastor era traçado a partir do fim da vegetação arbórea, em faixas transversais à divisão das águas. Ao longo destes territórios, cada pastor teria três postos em alturas diferentes nas montanhas. Estes postos seriam ocupados em épocas diferentes do ano, sendo que, conforme avançava o inverno, os pastores subiriam e no verão retornariam à zona do vale.

\section{3 - Nos últimos anos. Processos de reconhecimento das identidades indígenas}

Apesar dos dados que atestam a persistência indígena na região, a ideologia do período Colonial espanhol (que se estende até a atualidade da República) colocou os remanescentes indígenas como inexistentes, assimilados ou diretamente dizimados pelas guerras da conquista e/ou momentos posteriores. A negação foi utilizada como instrumento de invisibilização, exclusão e consequente dominação da parcela indígena. No processo subsequente da ocupação colonial, buscou-se eliminar o indígena a partir da absorção do elemento diferente. Foi imposta uma proposta ideológica de mestiçagem com o fim do branqueamento e homogeneização da população argentina. Este processo de mestiçagem coloca o indígena na posição de "agente de contaminação" que deve desaparecer lentamente até ser "diluído" na sociedade (Arruti 1997; Boccara 2007; Bartolomé 2008).

Esta ideia propiciou à Argentina (assim como a vários países da América Latina) a perpetuação da ideia de Nação homogênea e branca, a qual eliminara as minorias étnicas. No plano real, a proposta de mestiçagem somente trouxe uma distração à verdadeira realidade nacional, impondo valores e condutas hegemônicas, pela qual os grupos alternos seriam vistos como impuros e inferiorizados (Briones 2002).

As camadas indígenas da população argentina foram então consideradas inexistentes, parte de um passado exótico, distante e inalcançável. A República argentina reiterou o discurso hegemônico, postulando a condição de uma Nação branca sem índios ou negros. Em outras palavras, o processo que começou com a dominação da coroa espanhola no século XVI teve continuidade para as populações indígenas argentinas por vários séculos, sendo que, apenas no final do século XX, estas populações voltaram a ter parte dos direitos negados. Mesmo com a declaração da República em 1810, as políticas 
públicas e a ideologia sustentada na Argentina não mudaram radicalmente, continuou-se ressaltando as diferenças dos grupos pautadas nos instrumentos de dominação.

Ainda hoje, a visibilidade destes grupos enfrenta certa dificuldade por questões ideológicas, porém nas últimas décadas uma série de decisões políticas e legislativas promoveram a abertura a benefícios e direitos por tantos anos antes negados. Isto porque as diferenciações construídas mostraram-se ambivalentes, impulsionando aquelas regiões argentinas conhecidas por seu passado indígena em decorrência do surgimento dos processos mundiais de reconhecimento de identidade e outorgação de terras para os grupos minoritários. As reivindicações, respondendo a questões ideológicas e simbólicas de um passado no presente, abrem-se como uma forma de contestação contra uma determinada condição social e econômica (Briones 2002; 2007).

Somente nos anos de 1980, processos judiciais, na onda de processos neoliberais transnacionais, começaram uma discussão pelos direitos das minorias, inclusive os direitos indígenas e a diferenciação cultural. Assim, pouco a pouco, a imagem do indígena foi saindo do imaginário inanimado dos museus e começou a integrar as agendas jurídicas dos direitos humanos. Será na década de 1990 que a pré-existência étnica e cultural dos povos indígenas é finalmente reconhecida. Este processo de busca pelo respeito da sua identidade - e existência - marcha junto a outras demandas, como: a da pessoa jurídica das comunidades; ao direito bilíngue e intercultural da educação; à posse das terras tradicionais e propriedades comunitárias aptas e suficientes para o desenvolvimento humano. Desta forma, a Suprema Lei Argentina assegurou a estes grupos a participação na gestão dos recursos naturais e demais interesses que os afetem diretamente (Briones 2007; Carrasco 2000).

Por sua vez, estes processos de visibilização e reconhecimento das identidades não representou um processo homogêneo, mas respondeu diretamente à heterogeneidade de grupos diversos e diferentes que há tanto havia sido abnegada. Ao mesmo tempo em que houve um movimento geral em todo o território argentino a favor das comunidades indígenas, também houve indiferença e desinteresse, talvez por desconhecimento dos processos, medo de retaliações ou ainda por incompatibilidades na aceitação dos novos líderes que surgiam. No vale de Santa María, grande parte da população estava aquém dos movimentos indígenas, a participação foi exclusiva das camadas mais jovens da população local. 
Ainda, muitos grupos locais integraram-se e lograram alcançar as rédeas dos seus próprios destinos como comunidades indígenas dotadas de pessoa jurídica. Assim, nos vales Calchaquíes, os quilmes recuperaram a sua cidade que tanto foi utilizada para o turismo e a visão de um passado indígena visto como exótico e inexistente (Tolosa 2014). Os amaichas utilizaram o próprio poder colonial que os desterrou para recuperar as suas terras, indicando como documento válido de pertencimento uma cédula real onde a própria coroa espanhola lhes outorgara as terras que hoje correspondem a uma porção de Amaicha del Valle (Isla 2003).

No geral, os processos de evidenciação e reconhecimento das identidades indígenas mudaram o panorama em vários locais da Argentina. Evidenciou-se a existência - se não persistência - de uma série de instituições e formas de fazer política e economia se fizeram evidentes. Indicando que estes vales Calchaquíes, mesmo tendo sido considerados "pacificados" e "esvaziados" de indígenas no século VXII, o indígena nunca deixou de ser presente. Ainda hoje é comum fazer o festejo para a pachamama, juntas de anciãos e caciques continuam tomando decisões, caravanas e pastores seguem transitando pelas antigas vias no alto das serras e permanecem muitos dos modos tradicionais de usos da terra e de seus recursos, entre tantas outras características. 


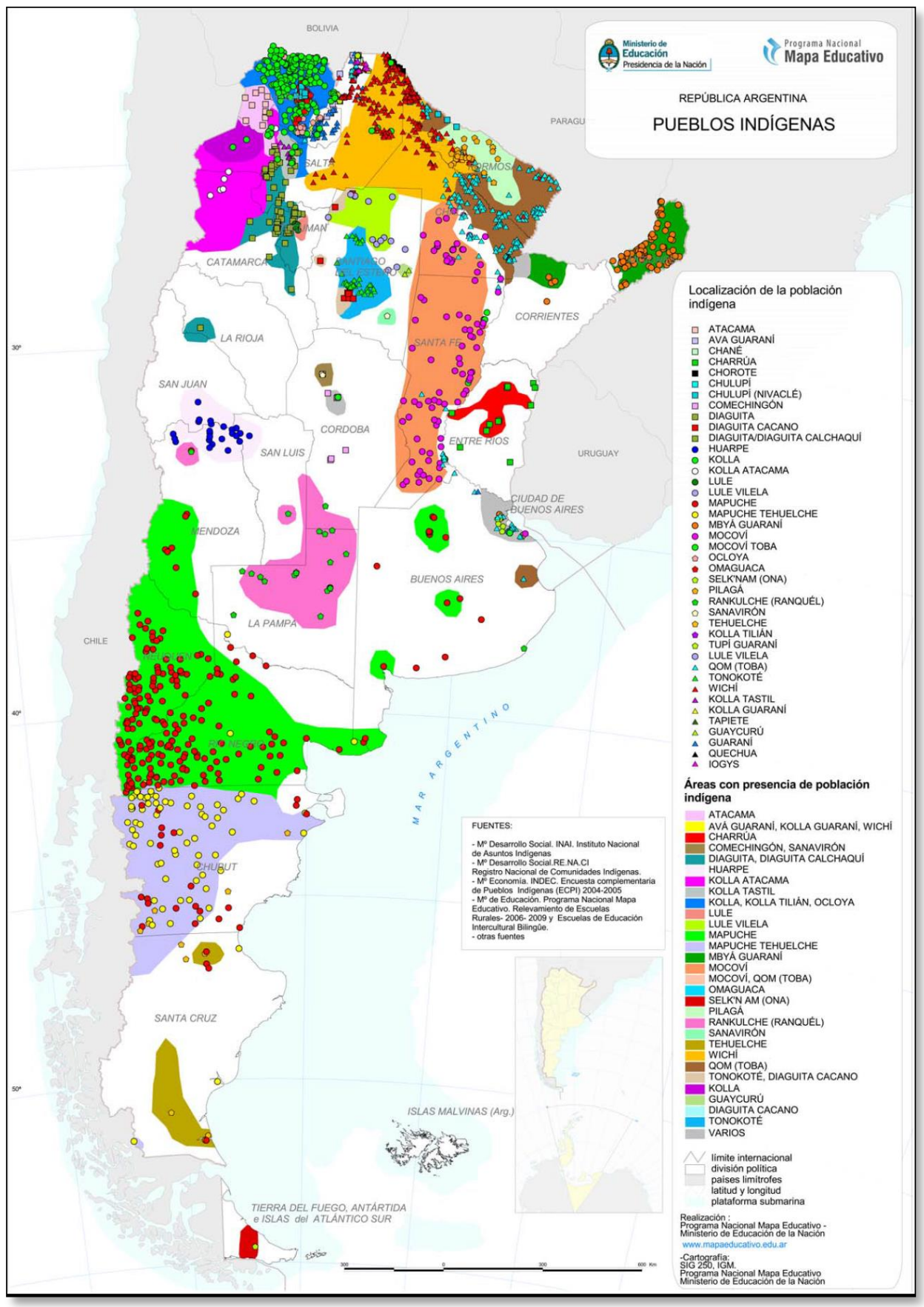

Figura 17 - Mapa indicando as diferentes comunidades indígenas e a sua dispersão no território argentino. Fonte: Atlas de los Pueblos Indígenas,

http://www.mapaeducativo.edu.ar/pueblos_indigenas/index.php?option=com_content\&view=article\&id= 


\section{2 - OS PASTORES. Os elementos do sistema pastoril no vale de Santa María}

Neste segundo capítulo, serão apresentados os elementos que constituem o sistema pastoril em Santa María. Identificar esses elementos permite entender o que é pastoreio, quem são os pastores e o que os torna pastores neste ambiente Andino. A partir desses pilares centrais serão discutidas outras questões intrínsecas ao sistema, como a divisão do trabalho, as questões de gênero e de faixa etária.

A proposta do capítulo é compreender como funciona o sistema pastoril neste vale, para refletir sobre as práticas locais, sobre o uso da terra e os recursos, o gerenciamento dos rebanhos e a percepção do espaço, para dar continuidade à discussão da tese.

1 - Os estudos sobre pastores

O pastoreio nômade é um modo de vida eficaz, principalmente quando se trata de ambientes áridos, frios e de solos difíceis para a agricultura. $\mathrm{O}$ movimento é uma parte natural do modo de vida destes grupos ((Haviland et al: 2011: 272-3). O pastoreio é um modo ancestral de produção, que implica um processo de adaptação a um determinado ambiente. Rebanhos de animais são parte dos padrões de subsistência para várias culturas ao longo do globo, desde o período Neolítico (aproximadamente). Considera-se que, no passado, os grupos pastoris foram centrais em várias transformações históricas, incluindo a emergência dos grandes impérios da antiguidade desde o norte da África até a Ásia e nos Andes Americanos (Kardulias 2015).

Os grupos pastoris do vale de Santa María, especializados no tráfego de longas distâncias e em animais resistentes ao frio e altitude, mantiveram-se desde o período pré- 
colonial nas serras, à margem das disputas que se estabeleceram com o avanço inca, hispânico e capitalista, preservando a sua autonomia e memória (Nielsen 2002, 2003). Nas regiões de maior altitude e mais distantes dos centros urbanos, pode-se destacar a persistência de muitos hábitos e tradições dos tempos pré-hispânicos. Este aspecto tem sido ressaltado por alguns autores (Nastri et al 2002, Browman 2008; Alezadeh 2008; Yacobaccio et al 2011), evidenciando a importância de se registrar estas persistências, a fim de que se possa expandir as interpretações sobre o conceito de vida nômade pastoril e a sua implicância identitária ao longo do tempo.

No geral, os grupos pastores tendem a ocupar diferentes nichos ecológicos em um ambiente, diante do qual criam estratégias para sobreviver (não prevenir) às crises. Para compreender o pastoreio, considera-se a relação entre os organismos e o meio que os rodeia, com foco na utilização de vários recursos de acordo com os regimes climáticos particulares. Como consequência, na tentativa de adaptação a um ambiente, as pessoas criam ordens culturais que manejam as condições desse ajuste. É o balanço desses elementos que determina a habilidade de um determinado grupo sobreviver associado a um certo número de organismos, portanto a relação dos pastores com certos animais não é apenas alimentar, implica na maximização de sua habilidade de sobrevivência e adaptação a condições ambientais variadas, através do tempo (Kardulias 2015).

Registros etnográficos mostram que os pastores apresentam grande diversidade nas estratégias de adaptação e especialização nas suas várias atividades econômicas, e que estas são parte de uma estrutura sociocultural (Frachetti 2008; David e Kramer: 2001: 266-270). Estes estudos têm produzido novas perspectivas, principalmente sobre a importância dos pastores no desenvolvimento econômico e político das regiões que percorrem (Smith 2008; Rosen 2008; Kuznar e Sedhneyer 2008). O pastoreio, portanto, é um fenômeno multifacetário, com várias definições possíveis, que envolve tanto questões ambientais como padrões variáveis socioeconômicas (Holl 1998; O’Dell 1994).

A atividade pastoril é uma motivação dentro de uma série de possibilidades ambientais e socioculturais, é um modo de vida que implica em escolhas em constante atualização de acordo com as condições, a percepção de mundo e a identidade dos seus praticantes (McCabe 2004). Parte-se do pressuposto de que os grupos pastoris não estão cristalizados no tempo, mas em um processo constante de atualização e ressignificação da sua atividade econômica e modo de vida. Sendo assim, não podemos considerar estes 
grupos como os últimos sobreviventes de um modo de vida, nem a sua atividade como a única alternativa a um ambiente específico.

Neste sentido, o uso do espaço também implica escolhas específicas, influenciadas por diferentes aspectos socioeconômicos e que isto também é um referente de identidade (Smith 2008). O uso recorrente de certas áreas passa a ter importância fundamental na elaboração da memória e da noção de pertencimento a um determinado lugar e território. As paisagens se tornam culturais e seus marcos e características, índices de identidade. Compreender esses diferentes aspectos também é uma forma de entender como os grupos se ordenam dentro do espaço, dando-lhe significado a partir de suas próprias percepções a respeito do mundo que os cerca e sobre si mesmos.

O pastoreio, portanto, é um modo de vida que varia de lugar a lugar, pois apresenta características muitos específicas. Dependendo do ambiente com o qual se está lidando, ainda lhe são plausíveis as mudanças e diversificação na economia. Generalizando, são característicos do pastoreio acampamentos efêmeros e busca por fontes de água e pastagens nas épocas de seca, associados ou não a um acampamento residencial fixo (David e Kramer 2001). Entre os grupos pastoris, existe uma relação muito estreita entre o movimento (direções e locais de parada) e as características específicas de cada ambiente e ainda com uma pequena agricultura associada aos movimentos dos animais (a migração natural desses bandos) e à sazonalidade com a domesticação de plantas. Portanto, os pastores têm uma noção clara do seu ambiente e das situações adversas, assim, ordenam o tipo e o tempo do movimento (Frachetti 2008).

A partir desta perspectiva, é possível pensar como se dão as práticas locais sobre o uso da terra e os recursos por estes grupos, o gerenciamento dos rebanhos e a percepção do território, sempre considerando as suas práticas de mobilidade. Desta forma, as estratégias de mobilidade respondem tanto às necessidades de obtenção de recursos, quanto à limitação do ambiente e à organização sócio-política do grupo em questão. A mobilidade pastora implica um conhecimento do território e planejamento das estratégias de acordo com o movimento do rebanho de local em local, que, muitas vezes, são fixos. Assim, se existe a utilização dos mesmos locais de parada, também existe uma previsão de tempo e condições climáticas que cada pastor faz considerando recursos de água e pastagens para os animais (Chang 2006). 
No caso de grupos pastoris que sempre retornam aos mesmo locais de parada, esta mobilidade logística dos pastores implica um movimento estruturado e repetitivo, o que permite que se desenvolva conjuntamente a agricultura. $\mathrm{O}$ plantio, associado ao movimento pastoril, permite que sejam exploradas áreas diferentes. No caso dos pastores nos Andes, o uso de altitudes diferenciadas permite uma variedade maior de produção de bens de consumo (Browmam 2008). A mobilidade pastora, portanto, implica movimentos cíclicos de um grupo, utilizando seu território por um longo período. Esta mobilidade, a longo prazo, envolve um território que é fixado em dois termos: inverno e verão (Chang 2006).

Os pastores apresentam uma domesticação da flora e da fauna em variabilidade regional, sendo que, como os forrageiros e os coletores, a sua mobilidade está ligada aos recursos do ambiente (Chang 2006). Existe um monitoramento de recursos de exploração além de planificação e previsão frente a um padrão regional de mobilidade. $\mathrm{O}$ uso do espaço levanta determinadas questões entre os grupos que leva a escolhas específicas, estas influenciadas também pela ordem social. Assim a maneira como os grupos escolhem para interagir com o meio a sua volta também é um referente de identidade étnica (Smith 2008).

A parte andina do Noroeste Argentino, tanto o altiplano como a puna, é uma região que vai do semi-árido ao árido e o pastoreio junto à economia vertical (característica dos Andes) é um mecanismo efetivo para um melhor aproveitamento dos recursos. Assim a concentração de recursos em regiões determinadas, desde os tempos pré-incaicos propiciou o desenvolvimento de um "suporte logístico" que, associado às redes de intercâmbio a longa distância, levaram a um posicionamento específico dos pastores frente ao ambiente natural e social desde a perspectiva da mobilidade (Browman 2008).

Desta forma, analisar um grupo pastoril implica compreender as conexões simbióticas entre humanos e animais domesticados com uma série de efeitos encadeados nas instituições e na adaptação humana. Por sua vez, os pastores demonstram uma capacidade alta de prosperar em áreas marginais, inclusive uma habilidade de mediar o seu envolvimento com outros grupos ou circuitos, o que possivelmente é a chave para compreender estes grupos (Kardulias 2015). 


\section{2 - De que pastoreio se está falando? Características e classificações}

O pastoreio envolve a resposta a dois fatores: a população humana e o tipo de pastagem. Porém, não é apenas o tipo de pastagem ou o crescimento populacional que estão impulsionando - e impulsionaram - a existência do pastoreio. Existem relações mais complexas com a cria e a domesticação animal. As categorizações mais comuns do pastoreio são referentes ao grau de mobilidade, que varia dos altamente nômades, transumantes ao agropastoril. Ainda assim, todas estas categorias são simplificações, os pastores são grupos extremamente flexíveis e oportunistas, podendo facilmente mudar os sistemas de gerenciamento e as operações produtivas sem afetar o cerne do próprio sistema. O cultivo e o uso de grãos para o rebanho, além das facilidades dos mercados e produtos do mundo moderno, não descaracterizam o pastoreio ${ }^{6}$ (Blench 2001).

O pastoreio tradicional distingue-se dos rebanhos produtivos e extensivos modernos pelo nível de investimento que é exigido em relação à terra e ao animal. Isto porque, o pastoreio tradicional se caracteriza pela adaptação a um determinado ambiente e às características do animal do rebanho, as pastagens não são plantadas. Historicamente é possível afirmar uma "boa integração" dos pastores e o ambiente que os rodeia. Os animais, geralmente adaptados, co-evoluem com o ambiente e o sistema pastoril, representando uma integração entre o estoque genético e as estratégias de gestão em relação a um determinado ambiente. Este não é um processo rápido, implicando em características imprescindíveis como a resistência às temperaturas, grau de umidade, e a aceitação ao tipo de pastagem. Sobre as pastagens, os pastores apresentam um interessante nível de preservação das pastagens naturais dos ambientes, ainda quando, as pastagens atuais representem o resultado da ação humana por mais de um milénio (Blench 2001).

Desta forma, a classificação de um sistema pastoril pode categorizar-se de acordo a um número de variáveis, entre elas as mais representativas seriam: 1) a localização geográfica; 2) a ecologia; 3 ) as espécies utilizadas; 4) o sistema de gerenciamento (Blench

\footnotetext{
${ }^{6}$ Um exemplo interessante se centra nas populações pastoras do Oeste da África, alguns representantes entre estes grupos praticaram um pastoreio transumante, mantendo boa relação de troca e aliança com os vizinhos. Com as vicissitudes do estresse ambiental e humano eles se tornaram extremante nômades, rompendo a maioria das alianças. É possível que se a crise chegar ao fim estes grupos voltem à transumância (Blench: 2001: 11).
} 
2001). No decorrer deste capítulo estas quatro classificações serão especificadas dentro do contexto do estudo de caso particular de Santa María.

\section{1 - Item 1 - Localização geográfica: vale de Santa María}

O primeiro item da classificação remete à localização geográfica. No capítulo anterior foi feita uma longa explanação sobre a área a ser estudada nesta tese. Desta forma, define-se como local geográfico a porção andina do Noroeste argentino, especificamente a zona compreendida pelo vale de Santa María.

\section{2 - Item 2 - A ecologia: Ambiente Andino}

Os estudos ecológicos, desde a antropologia, aprofundaram o suficiente nos significados das relações de interdependência entre os vários componentes de um ecossistema de terras altas com cultivos e pastoreio (Yamamoto 1985). Por sua vez, os estudos antropológicos, desde a ecologia, têm promovido, principalmente entre os anos 1960 e 1970, um avanço na forma de pensar a organização social e as estratégias de subsistência, integrando as noções de história à de ecossistema, considerando mudanças e permanências num tempo e espaço (Moran 1979).

Assim, a antropologia - transpassada pelo conceito de ecossistema - deu voz ativa à relação do contexto ambiental com a sociedade, rompendo com a ideia de um ambiente estático e abrindo espaço para se pensar nas inter-relações sistemáticas e numa escala regional (Moran:1979:16). A diferença que se estabelece, a partir do habitat e da organização social, reflete-se na forma de produção, na tecnologia e no estilo de vida. Neste contexto andino, onde temos mercados, agricultura e os pastores numa relação simbiótica de relações econômicas e complementaridade ecológica, a interdependência é a base da relação e da sobrevivência, permitindo o sucesso populacional e um aproveitamento do ambiente de forma efetiva (Tomoeda 1985; Yamamoto 1985).

Desde os tempos pré-hispânicos, apesar do ambiente extremo, as populações andinas souberam utilizá-lo e tirar o melhor proveito das suas terras, contornando as limitações e fazendo um bom uso das possibilidades de cada área ecológica. Nos períodos mais iniciais, a domesticação de lhamas e o cultivo de tubérculos possibilitou o 
desenvolvimento dos grupos humanos nas regiões mais altas da serra (Murra 1978). A domesticação persistiu e hoje perdura com um comportamento muito semelhante aos observados no passado.

Nos Andes Centrais, diferentes altitudes proporcionam uma grande diversidade ecológica que geram, por sua vez, diferentes zonas de vida. Apesar de não ser uma região de grande produtividade, as populações andinas conseguiram maximizar o potencial do ambiente, permitindo o aumento populacional sem deteriorar esse ambiente frágil (Yamamoto 1985). Estudos demonstram adaptações ecológicas paralelas em regiões de altitudes crescentes, como nos Alpes ou no Himalaia, porém, em nenhuma destas áreas, se alcançou a complexidade da contínua variabilidade dos Andes.

Principalmente, os Andes Centrais destacam-se por serem um importante centro de domesticação de plantas e animais, em uma série de áreas complementares e interdependentes. A grande diferença das altitudes provê esta diversidade ecológica, a alta cordilheira é caracterizada por estepes graduais e extensas pampas de altura, que são localmente divididas ${ }^{7}$ : Puna (regiões mais altas, superiores aos 4000m), Altiplano (ou pampas de alturas como se conhece localmente), área valliserrana (que são os vales) e a zona selvática (com altitude abaixo da área de serra).

Apesar de um fluxo constante entre todas as áreas ecológicas, a maior concentração reside entre a zona selvática e a puna. Nestas zonas, a domesticação e o manejo pelos grupos locais desenvolveram uma série de cultivos adaptados aos diferentes pisos ecológicos. Juntamente à complementaridade, a domesticação de animais para o pastoreio promove a manutenção e o fluxo pelas diversas áreas. Por isso, para entender o controle simultâneo desses diferentes nichos ecológicos, é importante entender a relação que existe entre as altas serras e os vales, em outras palavras, entre o pastoreio e a agricultura. Sendo que, esta relação pode ser resumida na existência de áreas com produtos adaptados a diferentes altitudes associados ao fluxo do pastoreio, que se movimenta pela necessidade de pastagens férteis e locais de água não perene para os animais.

\footnotetext{
${ }^{7}$ Existem variações nas nomenclaturas e na sua relação com a altitude de lugar a lugar, também pode ser encontrado como: Puna (de 4000m a 5000m), Suni (de 3000m a 4000m), Quechua (de 2000m a 3000) e Yunga (menos de 2000m) (Yamamoto 1985; Tomoeda 1985), ou ainda, como Puna, Altiplano, Serra, Pasto e Vale (Murra 1978).
} 
O funcionamento deste sistema é possível pelo fluxo contínuo por esses microambientes, que são alcançados num tempo curto de viagem. Existe um controle comunal, com terras em descanso e a fertilização dos solos com o estrume dos animais, este sistema remete a uma forma de uso da terra e de tecnologias que podem ser consideradas pré-hispânicas, pois são diferentes dos processos individuais com migração e horticultura especializada dos sistemas europeus (Yamamoto:1985:90).

Portanto, o ideal para o assentamento humano nos Andes é ter acesso às áreas de agricultura mais férteis nas regiões dos vales e às pastagens nas zonas mais altas das serras, tirando proveito das diferenças botânica e ecológica presentes em cada área. A existência dessas áreas complementares implica uma fauna e flora muito particulares que têm sido manejadas para se conseguir melhor produtividade a partir de uma boa adaptação. Em microambientes específicos, as plantas estão mais adaptadas e apresentam maior capacidade de competir com outras espécies. O crescimento e desenvolvimento de todos os organismos é determinado pela soma de diversos fatores psicológicos e biológicos a partir da interação, isto porque, nenhum organismo é independente do ambiente, está em constante influência do clima, sol, água e o homem, entre outros (Treshow 1970).

Nos Andes, a influência que a temperatura, a água e o solo têm sobre a fauna e a flora reflete na existência de organismos muito particulares e bem adaptados. Assim, de acordo com as altitudes, cada grupo de pessoas se dedicaria a uma cultura agrícola. Existe uma fronteira entre os agricultores e os pastores, uma distinção entre a altitude que habitam e, consequentemente, os produtos produzidos por cada um (Murra 1978).

Esta relação entre as partes produtoras e a transumância pastoril pode ser observada em todo o território andino. Nestes vales, as lhamas foram utilizadas como fonte de alimento, de couro, de lã para a tecelagem e também representam um importante valor como força de trabalho nas lavouras ou como carregadores. Isto fica claro quando observamos as caravanas, de grande importância para a reprodução do ambiente andino. As caravanas, desde os tempos pré-hispânicos até os dias atuais, sempre foram uma importante fonte de produtos e movimentam as economias regionais (Nielsen 2006).

A relação entre produtos agrícolas e os animais de pastoreio é mais complexa, não se restringe apenas às trocas. Desta forma, existe uma variedade desses sistemas de complementaridade ecológica nas diferentes partes dos Andes. Estas combinações de 
mecanismos não refletem apenas escolhas por razões ambientais, existem também as particularidades de cada coletividade. Assim, por todo os Andes se desenvolveu um sistema de complementariedade respondendo à relação pastoreio/agricultura, ainda quando as formas em que se estabelecem as relações de troca variaram e ainda variam muito (Salomón 1985). Em uma forma de simplificação, destacam-se quatro estruturas básicas dessa complementaridade ecológica, sendo que as combinações dessas formas podem variar de acordo com as regiões ou as diferentes épocas do ano: a) troca de produto por produto; b) troca de produtos por transporte com animais; c) troca de produtos agrícolas de duas áreas ecológicas diferentes; d) incremento de animais para a agricultura (Tomoeda 1985).

No que compete ao vale de Santa María, estas formas básicas observam-se todas integradas e de forma variada. Apesar de que hoje os rebanhos são variados, existem trocas de produtos (tanto de produtos animais como de produtos agrícolas, fruto de outras trocas ou coleta). Trocam-se produtos pelo uso para carga, principalmente dos burros ${ }^{8}$. A troca de produtos de áreas ecológicas diferentes hoje está quase que toda transpassada pelo uso do mercado e dos incrementos agrícolas, porém ainda existe, principalmente, na forma de reciprocidade entre pessoas; e o incremento de animais para agricultura geralmente existe na forma tradicional de uso do estrume animal para o crescimento de determinadas espécies e o manejo da flora. Este uso e conhecimento do ambiente andino dentro do sistema pastoril em Santa María serão melhor exemplificados a seguir - no item 4 - com os casos etnográficos.

\section{3 - Item 3 - As espécies utilizadas}

As espécies utilizadas nesta região correspondem a cabras, ovelhas, lhamas, burros e alguns cavalos. Existe uma distinção muito clara entre o nível de altitude e o animal pastoreado. Em zonas mais altas destaca-se a presença de lhamas e ovelhas, sendo que nas zonas mais baixas o pastoreio atual centra-se na presença de cabras. O burro é um animal que está presente em todas as altitudes (em maior quantidade junto às cabras). As ovelhas, cabras e burros foram introduzidos com o governo colonial, promovendo

\footnotetext{
${ }^{8}$ Algo que é muito comum nas expedições arqueológicas do Projeto Cajón, é que os pastores são contratados para carregar os equipamentos.
} 
algumas mudanças. Sobre esta discussão e a divisão de altitudes e os tipos de animais pastoreados se falará com mais detalhes a seguir.

Os camelídeos como as lhamas, tradicionalmente são os animais ideias pra os rebanhos andinos, segundo alguns pastores o problema de criar lhamas hoje em dia se centra na dificuldade da revenda dos seus produtos.

As cabras formam a maior parte dos rebanhos nestas regiões. As cabras não exigem cuidados especiais e se adaptam bem às áreas montanhosas e às oscilações da temperatura. As cabras conseguem se adaptar às pastagens pobres, e se orientam bem em uma variedade de terrenos, além de apresentarem o comportamento de mostrar o caminho para o rebanho (Kradin: 2015: Pos1307,16\%.DOI). As ovelhas também são animais de fácil adaptação a locais como os vales andinos, porém não foram identificados rebanhos de ovinos com muita frequência. Talvez, este tipo de rebanho, assim como o de lhamas, seja mais comum para zonas mais elevadas, pensando nos relatos sobre os rebanhos da infância de Guadalupe, que criou lhamas e ovelhas quando morava em Aguas Calientes (3000m), já Dom Vicêncio e Dom Yucra falam pouco de rebanhos de caprinos ou camelídeos.

As vacas não são consideradas produtivas para estas zonas, Dom Vicêncio explica que é porque a maioria das pastagens estão em altura e "as vacas não sobem nem descem bem a montanha". O mesmo acontece com os cavalos, que são criados apenas nas áreas mais baixas, para carga os burros têm maior utilidade na região de montanha.

Raramente os pastores criam cachorros, estes são mais comuns nas zonas urbanas. Porém nos últimos anos os pastores estão criando cães para a proteção do rebanho durante a noite, nos períodos de inverno quando os pastores estão no interior das serras. Estes cães são amarrados dentro dos currais de noite. Pois contam que no alto das serras, com a proibição da caça, a população de pumas tem aumentado significativamente e atacam os rebanhos e, em consequência, os pastores perdem vários animais.

\section{4 - Item 4 - Sistema de gerenciamento: Qual tipo de pastoreio?}

A United Nations Development Programme (UNDP) define o tipo de gerenciamento dos diferentes sistemas de pastores a partir da sua dieta, de acordo à 
dependência de sementes e produtos para os animais. Assim, considera duas modalidades de acordo com o proveito: a) sistema [apenas] pastoril, quando mais de 50\% do seu lucro provém do rebanho, utilizando pastagens não preparadas. Pode ser móvel ou transumante; b) agropastoril quando complementa com mais de $50 \%$ de cultivos, podendo ser transumante ou sedentário (Markakis: 2004: 14).

O sistema pastoril em Santa María pode ser definido como agropastoril com traços de transumância. Porém, ainda quando é possível definir o tipo de sistema de gerenciamento, existe uma grande variabilidade, inclusive dentre os sistemas que apresentam a mesma estrutura, raramente é possível definir dois sistemas pastores como iguais. Algumas das variáveis que atestam estas diferenças entre estes grupos pastores, são:

1-) Uso da terra e relação com o mercado: a) aqueles que dependem essencialmente da produção animal e não fazem trocas; b) aqueles que consomem ou produzem grãos, vendem leite, couro e peles e não produzem para os mercados (a participação no mercado aqui é uma estratégia de cooptar e não uma comercialização consciente); c) aqueles que usam o sistema rancheiro (ranching system) para produzir para os mercados; d) aqueles que apresentam total envolvimento com a comercialização, a privatização de pastagens e recursos hídricos, trabalho assalariado e incremento mercadológico (facilidades veterinárias, medicinas, maquinaria etc.)

2-) Produção do rebanho (pastoreio é apenas um dos vários sistemas de produção que existem relativos ao uso de rebanhos): a) pastoreio móvel e agropastoril; b) rebanhos assentados; c) relação entre rebanho e grãos; d) gado comercial; e) produtos lácteos.

3-) Diferenciação social: a) tamanho dos rebanhos; b) terras cultivadas; c) trabalho para outras pessoas.

A seguir, diante dos estudos de caso específicos, serão definidos cada um destes itens para uma melhor compreensão de qual sistema pastoril se está falando.

\subsection{1 - Conversando com Dom Vicêncio sobre o pastoreio}

Don Vicêncio é um dos pastores com quem trabalho em Santa María. Hoje ele é um homem de mais de oitenta anos que caminha com a ajuda de uma bengala. Já foram 
duas, depois que passou por uma operação, porém hoje já recuperou muito da sua mobilidade -, ele é um homem alto e forte, de pele morena e dentes bem brancos. É casado com Dona Maria. Eles têm cinco filhos e vários netos, nem todos eles são pastores, mas mesmo aqueles que não são têm alguma relação indireta com o pastoreio, como animais no rebanho de um terceiro ou visitas frequentes a locais que já foram para levar os animais.

Dom Vicêncio nasceu em Los Altos, do outro lado da serra do Cajón. Segundo ele, é uma zona mais úmida e fria que a parte oriental da serra. O pai de Dom Vicêncio era pastor de cabras e, com o rebanho, eles se movimentaram muito pelas serras do vale de Santa María. "Era pastor e um homem muito conhecido" diz Dom Vicêncio quando descreve o pai. O pastoreio era a atividade principal deles, todo o sustento da família girava em torno da criação de animais. Segundo conta, eles consumiam outros produtos - que não eram fruto de produção própria -, a maioria era conseguida por meio de trocas com vizinhos ou durante o processo de caravanas. Em questão de uso da terra e relação com o mercado, eles se encaixavam no item "b", já que consumiam produtos externos à cadeira pastoril, vendendo os produtos do pastoreio (animais, carne, couro e lá) para terceiros e havia uma relação com os mercados não direta através das caravanas. Uns dos produtos que Dom Vicêncio indica como muito procurados eram a farinha, o açúcar e a carne de lhama, que eles não produziam porque tinham cabras, mas que o seu pai trocava com alguns produtores que criavam lhamas por produtos que trazia das caravanas.

Don Vicêncio e seus irmãos ajudaram o pai na maioria dos labores diários com os animais. Conta que o tempo de aula era diferente em Los Altos, na temporada de inverno, com o frio intenso, as aulas eram suspensas e as crianças ajudavam os seus pais com os animais no alto das serras. Em questão de produção e rebanho, eles se encaixavam no item “a”, pois apresentavam características de um pastoreio móvel, com grandes rebanhos que eram mudados de locais para captar água e pastagens de acordo com o período do ano e a presença de movimentos longos durante as caravanas. Dom Vicêncio nunca falou que fizessem plantios e produzissem produtos agrícolas na sua infância, porém não é possível afirmar que não os houvesse.

A família de Dona Maria também era bem parecida em estrutura com a maneira como se estabeleciam como pastores. Na infância, Dona Maria vivia no interior da serra do Cajón, do lado oriental oposto aonde nasceu Dom Vicêncio. Quanto ao uso da terra e 
a relação com o mercado, também se encaixavam no item " $b$ ", pois consumiam e produziam produtos agrícolas além das trocas dos produtos dos animais. Dona Maria diz que o seu pai e seu irmão também empreendiam nas caravanas, porém ela nunca foi, pois ficava em casa ajudando a mãe. Ela conta que na casa de campo, que ainda lhes pertence, eles tinham um excedente de frutas no período do verão, com o qual faziam compotas e vários tipos de doces para a venda. Ela diz que não se lembra de ir até a cidade comprar produtos, porém tem certeza de que já faziam uso de produtos frutos de trocas, talvez com algum vizinho.

Quando à produção e rebanho, a família de Dona Maria também se encaixa no item "a". A mobilidade do pastor e do rebanho, segundo ela se lembra, não era intensa, porém o rebanho somente ficava na proximidade da casa nos períodos mais férteis. $\mathrm{O}$ caso da família de dona Maria é o clássico tipo agropastoril móvel, pois ela indica que tinham uma vasta produção agrícola para uso próprio e com um pequeno excedente que podia ser usado para trocas e vendas.

Quanto à terceira variável, tanto Dona Maria como Dom Vicêncio destacam que o grande valor era o tamanho do rebanho. Eles contam que os pais tinham grandes rebanhos com mais de 200 animais. Não havia muita distinção sobre terra, pois todos tinham a mesma quantidade, afirma Dom Vicêncio e, se não tinham, cruzavam ou utilizavam a terra dos vizinhos, pois os locais de água e boas pastagens apresentavam-se num regime muito parecido ao que seriam as terras comunitárias. Quanto a empregar pessoas alheias, isso acontecia quando necessário, porém não no sentido de um trabalho constante assalariado. As pessoas empregadas respondiam a regimes diferentes de trabalho/pagamento.

Quando Dom Vicêncio e Dona Maria se casaram eles foram morar na casa dos pais de Dona Maria no alto da serra em Santa María. Lá viveram por vários anos até a filha mais velha entrar na escola. Dom Vicêncio conta que ele continuou pastoreando o rebanho da maneira como o seu sogro fazia, tanto os caminhos como os lugares que o sogro já utilizava. Dona Maria continuou produzindo as compotas e doces das frutas e continuaram tendo horta. $\mathrm{Na}$ casa, também tinham outros animais, como porcos e galinhas. Mantiveram a mesma lógica do sistema pastoril no qual Dona Maria havia crescido, sem apresentar grandes mudanças, inclusive quando foram para mais próximo à cidade. 
Apesar da mudança a Las Mojarras, localidade mais próxima à área urbana de Santa María, eles conseguiram reproduzir muitos dos hábitos e costumes da vida no interior da serra. Morando ao pé do serro durante a semana, todo final de semana, subiam a serra e ficavam no Churqui (nome da fazenda dos pais de Dona Maria). Os filhos e os netos cresceram fazendo esse trajeto e o sabem de cor, conhecem todas as voltas e caminhos e hoje levam os netos pequenos para fazer pequenos passeios na serra.

Durante vários anos, Dom Vicêncio subiu e desceu a serra todo dia para cuidar dos animais. Dona Maria diz que ele nunca dormiu fora de casa, assim como o seu pai. Ela diz que ele saía cedo. Quando os primeiros raios de sol apontavam, ele já estava saindo e voltava logo à noite. Diz que subia até onde estavam os animais e quando era necessário os levava para outros locais.

Dona Maria conta que, um dia, ficou tarde e Dom Vicêncio não voltava e ela estava preocupada. Isso foi há muito tempo, já viviam na casa nas Mojarras, mas os filhos mais velhos dela ainda eram crianças pequenas. Diz que ficou na porta da casa olhando para a serra esperando ver alguma coisa. Então, por volta das dez horas da noite viu um vulto. Era Dom Vicêncio que trazia nos ombros um leão (um puma ${ }^{9}$ ) morto. Ela diz que ficou muito brava, mas Dom Vicêncio que ouve a história ri. Ele afirma (indicando para si com o dedo indicador em sinal negativo) que não deixava um, porque se deixasse eles acabavam com o rebanho, e os animais eram o sustento deles.

Dom Vicêncio, durante alguns anos, trabalhou em San Miguel de Tucumán, na capital da província de Tucumán, e assim voltava nos finais de semana pela estrada provincial no 307 para Las Mojarras. Com isso, foi preciso encontrar alguém para estar na casa da serra, pois ficava difícil cuidar dos animais na serra. O Churqui está alugado para Dom Lorenzo. O aluguel do Churqui com o rebanho já passou por quatro pessoas.

Hoje, na casa das Mojarras, eles têm dois tipos de cabras em um rebanho bem menor do que já tiveram, algumas que ficam por perto da casa e outras que eles levam para o alto das serras A família encarrega-se de fazer isso. Mercedes, a mulher do filho mais velho deles, conta que, para Dom Vicêncio e Dona Maria ficou mais difícil cuidar

\footnotetext{
${ }^{9} \mathrm{Na}$ região chamam de leão ao puma (Puma concolor, antes Felis concolor), grande felino que habita desde a Columbia Britânica no Canadá até o Estreito de Magalhães no estremo sul da América do Sul. Apresenta uma coloração castanho claro e não apresenta manchas. É um animal territorial, emite rugidos e também ronrona. Hoje em dia, está em risco extremo de extinção, já tendo desaparecido da maior parte do seu território original, inclusive com uma população extremamente reduzida nesta região dos vales andinos.
} 
dos animais, ir buscar e levar, ainda mais porque Dona Maria, com a idade, está tomando muito carinho pelas cabras e fica com pena de ter de matar uma cabra para comer ou vender. Porém, mesmo com a idade avançada, eles continuam tendo os seus animais para pastorear e, mesmo com o bastão para ajudar a andar, Dom Vicêncio caminha todas as manhãs pela serra do Cajón. Ele pode não ir tão alto, mas não abandona os caminhos já tanto caminhados.

Estas variáveis são importantes para compreender com qual estrutura de pastoreio se está lidando, no momento da análise. É possível, através do comportamento de algumas pessoas, destacar estas características no sistema pastoril.

A cidade de Santa María está dividida em um centro urbano e uma área rural. A atividade do pastoreio tem-se focado quase que exclusivamente na região das serras. No interior da serra do Cajón, a população é dispersa e se dedica principalmente à atividade agropastoril (agricultura em menor medida que o pastoreio). Próximo às pequenas vertentes de água não perene, existem diversos postos de parada em diferentes altitudes Estes postos são utilizados pelos pastores da redondeza, geralmente em momentos diferentes do ano. Os pastores apresentam um grau de movimentação, levando e trazendo os animais das áreas de pastagens e água. A mobilidade desses pastores pode ser considerada como vertical, pois eles se instalam nos vales (altitudes entre $2.500 \mathrm{~m}$ e $3.000 \mathrm{~m}$ ) durante os meses de verão e nas altas montanhas (entre $3.000 \mathrm{~m}$ e $3.500 \mathrm{~m}$ ) no período do inverno (logo se discorrerá mais sobre o sistema pastoril com detalhes).

No geral, o pastoreio é uma atividade eminentemente masculina. Característica que se mantem em Santa María. São os homens que pastoreiam os animais, acompanhados das crianças pequenas, que estão ali para aprenderem a profissão. A base da organização pastoril geralmente responde a uma ordem patrilinear, assim como na maioria das sociedades pastoris que apresentam geralmente descendência patrilinear e uma relação com o homem adulto dominante no círculo familiar. O papel feminino no gerenciamento dos rebanhos tem sido bastante discutido, inclusive observa-se uma semelhança muito grande em todas as estruturas sociais pastoris ao longo do globo (Blench: 2001: 41-43).

Na maioria das sociedades pastoris, a divisão por gênero é fortemente marcada, as mulheres são responsáveis por determinadas tarefas, geralmente tendo total controle dos processos relativos à família. Na sua maioria, ficam fixas nas casas enquanto os 
homens se movimentam. Os homens são responsáveis pelo rebanho e as atividades que implicam no pastoreio dos animais, e as mulheres e as crianças pequenas têm outras obrigações em relação ao rebanho, porém quando é o período das chuvas abundantes e os rebanhos estão próximos às casas, as mulheres também podem ocupar-se dos animais. Existe uma divisão por gênero e por idade em relação às tarefas relativas à vida pastoril, porém isso não é um empecilho para a atividade feminina no cuidado dos animais, como é o caso de Guadalupe, a única mulher pastora que conheci.

\subsection{2 - Guadalupe. Uma mulher pastora}

Quando bebê, Guadalupe, foi morar com a avó materna que a criou até os seus oito anos. Esta avó era oleira e lhe ensinou a trabalhar o barro. Quando a avó faleceu, ela foi morar com os tios, a quem chama de "pais de criação", ou simplesmente por "mãe" e "pai". Tanto a avó quanto os pais de criação de Guadalupe eram pastores e foi com eles que ela aprendeu tudo o que sabe sobre o pastoreio. Eles tinham um rebanho variado de lhamas, cabras, ovelhas, além de burros e alguns cavalos, eram uns 600 ou 400 animais ao todo, de acordo com Guadalupe. Ela conta que era muito interessada no trabalho e não tinha medo de nada, por isso "cuidava do rebanho e o fazia bem". Guadalupe cuidava dos animais e esquilava as lhamas e ovelhas para vender a lã. Ela também sabia fiar a lã, tecia com agulhas e usava dois tipos de tear ${ }^{10}$, fazia ponchos para o inverno e meias para usar com sandália de plástico, conta. Guadalupe diverte-se contando sobre os trançados, os desenhos que fazia e de como ela gostava de amarrar pequenos pompons nas meias e ponchos para dar um charme.

Como a mãe não teve filhos, eram várias as mulheres na casa e Guadalupe ajudou o pai com o pastoreio - atividade que não é comum para mulheres -. Quando todas cresceram, o pai deu uma casa para cada filha, mas Guadalupe não quis e pediu ao pai uma parte do rebanho, assim, ela ficou com duzentos animais. Conta que ficava no alto da serra e cuidava muito bem do seu rebanho, diz que fez um bom dinheiro e aumentou o rebanho da família em número de animais. Existe uma distinção entre aumentar o

\footnotetext{
${ }^{10} \mathrm{Um}$ dos tipos, é o telar de peite, um grande tear que usa dois pedais para funcionar e a todo momento passa um pente que é o que produz o emaranhado da lã. O segundo é o tear feito com pequenas pedras, nas quais se amarra a lã, os fios são trançados a partir do movimento das pedras.
} 
rebanho em número de animais e aumentar em preço; segundo conta, Guadalupe era uma boa pastora.

Em questão de uso da terra e a relação com o mercado - a primeira variável que a UNDP apresenta - eles dependem essencialmente dos produtos animais, porém efetuavam trocas dos próprios produtos por outros que necessitavam, assim encaixam-se no item "b". Guadalupe conta como ela fiava e tecia casacos e meias com a lã dos animais do seu rebanho. Estes produtos eram para a venda. Assim como os produtos, os próprios animais também eram vendidos.

Guadalupe não fala de caravanas, apenas as que passavam por eles. De acordo ao que Dom Vicêncio conta, as caravanas não apenas trocavam produtos, mas também recolhiam animais pelo caminho. É provável que, como o pai de Guadalupe não teve filhos homens, eles não participassem das caravanas. Portanto existem duas opções possíveis, talvez eles diretamente não vendessem os animais no mercado regional, ou os animais eram entregues a caravanas de terceiros em troca de produtos.

Na questão da produção e do rebanho, o tipo de pastoreio que Guadalupe apresenta pode incluir-se no item "a" (assim como o sistema pastoril de Dom Vicêncio), sendo um sistema de pastoreio móvel, onde os animais se movimentam até áreas com pastagens e água para a sua sobrevivência. Em questão de produção agrícola, Guadalupe destaca a presença de pequenas hortas com alguns produtos e uma coleta de produtos de estação para complementar a dieta.

Sobre o rebanho, de acordo com o que contou Guadalupe, o número de animais e a variedade de animais que a família dela tinha eram muito superiores aos outros números que coletei nessas serras. Talvez por isso, Guadalupe sempre afirme que o pai era um homem rico, tanto que pôde dar uma casa e animais para cada filha.

Guadalupe conta que apesar de ter aumentado o rebanho em número, o pai não aceitava bem que ela fizesse algumas coisas diferentes, mesmo que fossem para o bem do rebanho. Ela diz que o pai era um homem muito tradicional e que não queria modificar em nada o modo como cuidava e lucrava com os seus animais. Por isso Guadalupe não continuou na casa do pai. Na casa em Aguas Calientes, Guadalupe aprendeu o que "precisava" para viver: cuidar dos animais, fazer cerâmica, cuidar de uma casa e encontrar 
comida. Hoje, ela já não tem rebanho, mas se apena, diz que se tivesse o dinheiro e a oportunidade era o que gostaria de fazer.

Guadalupe, ainda continuou trabalhando nas serras, porém próximo a Santa María, até que um dia ficou sem trabalho. Ela conta de épocas difíceis que eram obrigados a caçar e a pagar um tipo de imposto. Guadalupe não conseguiu se movimentar com o seu rebanho e diz que tampouco quis vender os animais que o pai lhe deu. Por isso, conseguiu trabalho para cuidar de alguns rebanhos. Ela conta que inicialmente era um trabalho lucrativo, pois poderia aumentar o número de animais do rebanho e uma porcentagem era dela. Também poderia cuidar dos animais próprios junto ao rebanho que gerenciava. Porém começaram a lhe cobrar vários tipos de "impostos".

Um dos pagamentos que ela fazia era referente ao movimento pelas serras. Uma das questões fundamentais deste tipo de pastoreio do qual estamos falando é a movimentação do pastor juntamente ao seu rebanho. Esse movimento se dá em busca de pastagens e água para os animais. Impossibilitar um pastor a se movimentar implica na perda do rebanho ${ }^{11}$, portanto Guadalupe pagava esse tipo de pedágio exigido para se movimentar por certas áreas para alcançar as pastagens e águas para os animais. Outro pagamento que lhe era exigido era referente aos animais. Uma porcentagem do que deveria receber do dono dos animais por gerenciar o rebanho, era abatida, pois ela estava criando mais animais juntos e também algumas promessas que lhe tinham sido feitas sobre a porcentagem de lucro sobre o aumento dos animais do rebanho e da venda dos produtos animais não era cumprida seguindo o acordado. Isso fez que a possibilidade de ser pastora para Guadalupe se tornasse algo muito difícil ao ponto de ela abandonar essa vida e se mudar para a cidade em busca de outros empregos.

Quando Guadalupe estava contando isso, perguntei se a causa desses pagamentos que ela era obrigada a fazer seria por causa de ela ser uma mulher com o rebanho. Guadalupe ficou pensativa e disse que talvez, pois com os homens não teriam tido coragem de fazer as coisas como foi feito com ela.

O caso de Guadalupe não é único, porém são casos bem pontuais. Na estrutura de divisão do trabalho pastoril, a parte que cabe ao cuidado do rebanho é masculina. A divisão do trabalho por gênero é algo que foi incessantemente estudada. As características

\footnotetext{
${ }^{11}$ Este assunto será retomando com mais detalhes mais a frente, ao falar sobre mobilidade pastoril.
} 
e os tipos variam de grupo a grupo, portanto é útil entender o contexto da divisão do trabalho no contexto do grupo específico (Haviland et al 2011). Neste contexto pastoril dos vales de Santa María, encontra-se uma divisão do trabalho - ainda que flexível - por idade e por gênero, num viés que implica mais a complementariedade que a segregação dos pares.

\section{3 - Divisão do trabalho}

A divisão do trabalho entre os pastores ocorre de acordo à faixa etária e o gênero. As crianças em idade de ajudar desempenham uma série de tarefas simples, como ir buscar os animais próximo às casas, ou ajudar os pais com o rebanho. De acordo aos dados coletados, não importa o sexo das crianças quando se trata das tarefas mais simples. As filhas de Dom Vicêncio contam várias histórias que decorrem como pano de fundo do momento em que iam recolher os animais nas serras próximas às casas, inclusive estas histórias - contadas às crianças, como divertimento - apresentam todo um modo de comportar-se e responsabilidade. Uma das histórias que ouvi foi a de Celeste. Ela diz que saiu com os primos a recolher o rebanho numa área próxima à casa que moravam no interior da serra. No caminho, diz que eles foram brincando e gritando pelas serras que vinha um leão. Ela conta que já era tarde e não haviam recolhido os animais e continuavam brincando e assuntando-se uns aos outros. Foi nesse momento que o tio que estava próximo foi procurar por eles, todos foram repreendidos pela brincadeira perigosa (que lembra a história de João e o Lobo) e por terem demorado, sendo que já era tarde e eles apenas deveriam concluir com a simples tarefa de recolher os animais.

Dom Vicêncio conta que uma vez, era pequeno ainda e estava pastoreando umas cabras e no meio de uns arbustos viu um leão, o animal estava paradinho e Dom Vicêncio conseguia ver as patas dele como se estivesse sentado. Diz que ficou com medo, estático, tratando de fazer o menor movimento possível. Depois de um tempo parado, percebeu que o animal tampouco se mexia. Tomou coragem para ir chegando mais e mais perto. Ao chegar bem próximo, percebeu que, na verdade, era uma rocha cujo formato imitava perfeitamente um leão sentado. Diz que riu muito apesar de ainda estar nervoso por conta da situação. 
Este tipo de história é comum entre estas pessoas. De uma forma despreocupada, elas indicam às crianças o que podem ou não fazer. Por outro lado, elas dão as bases de uma organização do que é uma responsabilidade infantil: recolher os animais, estar atento às horas de luz do dia, não se ausentar da casa para não acontecer nada com eles e nem perderem o rebanho. Outras atividades que as crianças levam a cabo é ajudar nas hortas, na preparação da comida, etc. Estas são todas atividades que não apresentam divisão por gênero, são para todas as crianças no geral.

Os idosos, ao que parece, são praticamente liberados das tarefas por uma questão totalmente ligada à idade e resistência física. Assim, os filhos ocupam-se da maioria dos trabalhos que exigem muito dos pais que passam a efetuar tarefas mais simples. Porém, não do mesmo tipo que as das crianças. Outra questão importante é ainda sobre a relação com o abate do rebanho. Algo que foi colocado várias vezes em campo é sobre "não ficar brando" e "não tomar demasiado carinho" para não ficar apenada quando são abatidos.

Desta forma, somente os adultos com uma determinada idade, dedicam-se a todas as instâncias do pastoreio. São feitas divisões por gênero, apenas os meninos em determinada idade ajudam ativamente em todas as instâncias que implicam no pastoreio de animais nos percursos da serra. Dom Vicêncio conta que ele acompanhava o pai quando menino ao longo do percurso das caravanas, inclusive as aulas da escola obedeciam a períodos diferentes do usual ${ }^{12}$, justamente para que os meninos pudessem ajudar os pais com o rebanho nos meses de inverno pois os movimentos para encontrar pastagens e água para os animais são mais longos.

Dom Vicêncio conta que ele e os irmãos levavam os animais para pastar e os recolhiam depois e quando chegava a época em que o seu pai seguia as caravanas para vender as cabras no mercado regional em San Pedro, eles iam junto. Ele conta que o pai era um homem importante. Ele sempre coordenava essas caravanas. Saiam de Los Altos e ia andando pela serra, seguindo os caminhos e passando pelas casas. Nas casas, juntavam animais para levar para vender e pedidos e produtos para trazer na volta. No caminho, também se uniam a outros grupos e pessoas e seguiam juntos, levando os animais até San Pedro. Ele conta que ainda era um menininho, mas já ia pois ajudava o

\footnotetext{
${ }^{12}$ Normalmente, na Argentina, as aulas têm início nos primeiros dias de março, tendo uma pausa chamada "férias de inverno" por duas semanas de julho, e finalizando o ano letivo em dezembro. Ao que parece, nestes vales, o período das férias de inverno se alonga vários meses.
} 
pai. Diz que era cansativo, pois andavam muito e dormiam pouco, mas ele gostava. Dom Vicêncio ainda acrescenta que se exigia certa disciplina deles, não se podia brincar para não perder o ritmo. Diz que assim foi aprendendo tudo o que o pai sabia sobre o cuidado dos animais, os caminhos a seguir, e como se organizar para cuidar e não perder animais nem o rebanho.

As meninas, conta Dona Maria, ficavam nas casas ajudando a mãe. Ajudavam com os irmãos, a fazer os concertos necessários quando o pai estava ausente. Estes eram dos mais variados tipos, desde concertar os telhados e até cercados, a preparar alimentos e coisas para a venda. Diz também que elas cuidavam dos animais pequenos. Nem todos os animais do rebanho se movimentam pelas serras, existe uma separação. As fêmeas prenhas e os pequenos animais ficam na área das casas, pois não resistiriam ao frito e ao movimento constante. As fêmeas no cio também ficam separadas dos outros animais. Assim, na área da casa, as mulheres ocupam-se desses animais que, na ocasião, não estão integrando os rebanhos, e das outras criações, como porcos e galinhas. As hortas e pomares das casas também exigem cuidados.

Guadalupe conta que quando ela vivia no alto da serra, já fez muitos currais de pirca $^{13}$. Ela diz que tratava muito bem os seus animais (diz isso com um grande sorriso no rosto). Conta que fazia currais com casinhas para os animais pequenos e que eram tão bem feitas essas casinhas que as pessoas diziam que pareciam casa para gente, ela sorri mais ainda e me fala baixinho, quase em confidência, que os animais eram pequenininhos e que precisavam ser cuidados.

Também se lembra de quando fazia panelas de cerâmica. A avó dela era oleira e foi quem a ensinou esta outra atividade feminina ${ }^{14}$. Assim, Guadalupe conta que ela e a avó faziam grandes panelas de cerâmica, com pescoço longo e fino para manter a água fresca, e também as que iam para o fogo. Ela diz que a argila se conseguia no alto das serras, mas não muito próximo de onde elas moravam. Diz que preparavam a argila, que a deixavam descansar uma noite inteira para, logo no dia seguinte, formar as panelas. Inclusive, para fazer a cerâmica, os animais eram indispensáveis. Era preciso o estrume, o couro e o sangue. Guadalupe diz que quando tinha de matar um burro para retirar o

\footnotetext{
${ }^{13}$ Palavra usada para se referir a pedras empilhadas.

${ }^{14}$ Hoje em dia, poucas pessoas ainda trabalham a cerâmica nestes vales, a maioria dos utensílios são comprados industrializados.
} 
couro, fazia-se um buraco no chão, preenchia-se com galhos em baixo e se acomodavam as peças frescas, logo se cobria com estrume de animal e se ateava fogo. Quando estava finalizada a queima, cobriam com o couro do burro. Ela também conta, de forma muito breve que, ás vezes, utilizavam sangue dos animais na mistura da argila e para fazer pintura $^{15}$.

Quando chega o momento de tosquiar os animais isso também é trabalho feminino. Existem currais para separar os animais para serem tosquiados. A lã é lavada e fiada e, em alguns casos, também são feitos produtos para a venda. Guadalupe começa a relembrar com quanto cuidado ela esquilava os seus animais, que cuidava para não puxar o pelo, assim eles não se incomodavam, por isso, quando ela esquilava, eles ficavam todos quietinhos e ela terminava em menos tempo. Depois, ela diz que cuidava bem da lã dos bichinhos, porque tinha sido deles. Ela diz que fazia tão bem os seus tecidos que as pessoas procuravam as suas peças. Tudo isso alegra Guadalupe, são boas lembranças para ela.

No caso de Dona Maria, ela diz que não tosquiavam os animais, pois tanto seus pais quanto Dom Vicêncio s sempre tiveram cabras. Porém Guadalupe, que viveu boa parte da vida em locais mais altos, tinha lhamas e ovelhas.

Geralmente, os homens ocupam-se do pastoreio, no sentido de que são eles quem se movimentam no interior das serras quando necessário. As mulheres permanecem nas casas e ocupam-se do que deve ser feito ao redor da área residencial. A relação entre as duas partes é indiscutivelmente necessária, pois sem as mulheres para cuidar dos animais pequenos, não haveria rebanho no futuro próximo, e sem os homens para se movimentarem e alimentarem os animais também perderiam os rebanhos. Observa-se uma divisão de trabalho complementária de gênero e faixa etária, que se assemelha a um trabalho cooperativo, onde a unidade básica é o núcleo familiar, sendo uma unidade de produção e consumo (Haviland et al 2011).

\footnotetext{
15 Talvez não tenha entendido muito bem, sobre o sangue e a pintura, pois estava falando dos pigmentos que utilizava para um colega, e como tudo era muito corriqueiro para Guadalupe e pouco compreensível para mim, talvez apenas utilizassem o sangue como meio de mistura para o pigmento, ou talvez unicamente para a argila.
} 


\section{4 - Divisão do espaço: o alto das serras e os vales}

Em relação à divisão de trabalho por gênero, ao que parece, não existem restrições muito rígidas para ser flexibilizada a relação. A questão fundamental parece vir de outra condição, que está relacionada mesmo que indiretamente. Guadalupe, como foi dito, aprendeu a atividade do pastoreio e foi pastora durante vários anos. Por problemas externos à atividade do pastoreio, foi que deixou de atuar. Se não tivessem lhe cobrados os impostos, ela acredita que teria aumentado o rebanho - como já tinha feito - e conseguido sustentar-se sendo pastora.

A questão que impede Guadalupe de ser pastora hoje em dia é um problema de gênero que é refletido na atividade do pastoreio, porém não nasce dela propriamente. Então, por um lado, Guadalupe tem um problema com segurança e, por outro, tem um problema pela sua permanência nas serras.

A segurança implica que ela não é um homem, portanto não logra fazer frente a certas situações. Outra questão fundamental é a permanência nas serras. Resumindo, as serras são locais de pastoreio, portanto são zonas concorridas por homens. Dom Yucra, um pastor que habitou toda a sua vida no vale de El Carmen - do outro lado da serra do Cajón - conta que ele, sendo menino, acompanhava os pastores nos caminhos de pastoreio. Conta ainda que sua mãe era oleira e que todas as mulheres eram um pouco oleiras naquela época (ele tem mais de 60 anos), assim todas as mulheres sabiam fazer as panelas básicas, mas, se necessitavam de alguma mais elaborada, tinham de pedir a uma determinada oleira, pois havia algumas mulheres que se especializavam nesse serviço. $\mathrm{O}$ caso é que os locais para a retirada de argila boa estavam localizados nas regiões mais altas das serras. Ele conta que a sua mãe sabia exatamente onde deveria ir buscar argila, porém era ele que ia buscá-la, pois ficava bem no percurso de um caminho de pastoreio. Assim, quando a mãe precisava, ela o avisava e ele, desde muito cedo, subia a serra e ia buscar a argila para a mãe.

O espaço do alto das serras é exclusivo ao pastoreio e aos pastores. É como se fosse uma área para os homens. As mulheres permanecem nas áreas residenciais, fazem os caminhos de pastoreio, que, no geral, todos conhecem apenas como passeios, mas não como atividade diária. Portanto, ao definir um espaço como principal marcador para se falar de pastoreio, este deve ser a serra e é possível fazer uma divisão entre o que é a zona 
de serras e a relação de gênero. Esta relação parece extrapolar o tempo, indicada desde períodos antigos.

Especificamente, na região que corresponde ao vale de Santa María juntamente ao Vale do Cajón, a contínua presença de pastoreio na área do interior das serras é evidente. Destacam-se estruturas arquitetônicas que correspondem à infraestrutura produtiva de gado em contraste a sítios que são designados como categoria funcional de habitação. Ainda, a presença de animais domésticos para o pastoreio pode ser constatada, a partir de estudos com restos faunísticos (Izeta e Scattolin 2006).

Os sítios arqueológicos apresentados por Catarelli e Torcoleti (2009) indicam a presença de áreas habitacionais associadas a currais, numa altitude intermediária de 2700m, provavelmente ocupados no Período Tardio (entre ca.1000 a 1430). Já sobre o cordão montanhoso, Nastri e colaboradores (2002) identificaram um padrão de sítios que reconhecem como postos pastoris, os quais constituem: grandes recintos (identificados como currais) associados a recintos pequenos (identificados como o refúgio do pastor). Ao adentrar a porção central da serra do Cajón, principalmente nas quebradas, alguns sítios arqueológicos identificados indicam a existência de pequenas instalações préhispânicas semelhantes aos postos de pastores da atualidade (Cantarelli et al 2014), juntamente a outras estruturas dispersas pela serra que datam do Período Intermediário Tardio, num momento indicado aproximadamente no século XIV e na primeira metade do século XV (Moritan et al 2015; Cantarelli et al 2014) ${ }^{16}$.

Por sua vez, Sanz de Arechaga (1948) observa que os pastores passavam a maior parte do ano - de outubro a abril - entre os $2000 \mathrm{~m}$ e os $3000 \mathrm{~m}$. Este trecho é uma zona de maior presença de água e pastagens, que cessam no período de inverno e que juntamente aos ventos frios que sopram da região da Puna, obrigariam os pastores a alcançar maiores altitudes onde as pastagens ainda permanecem. Por isso, de maio a julho, os pastores seriam obrigados a buscar pastagens em maiores altitudes - entre os $3000 \mathrm{~m}$ e os $3.500 \mathrm{~m}$ - nos grandes ciénagas (locais com grande quantidade de nascentes) onde a

\footnotetext{
${ }^{16}$ Estes trabalhos - vinculados ao Proyecto Cajón, sob a direção do Dr. Javier H. Nastri - continuam em andamento levantando dados referentes a estas ocupações pretéritas no interior da serra do Cajón. Cada vez mais, é possível assumir uma postura que indique a presença do pastoreio desde tempos pretéritos até os dias atuais Diante de tal afirmação, é indispensável deixar claro que não se está afirmando uma continuidade étnica direta, mas a continuidade de um modo de produção e aproximação à paisagem.
} 
água aflora no verão e cresce uma vegetação resistente, chamada "pasto de raiz". Porém, quando as propriedades são pequenas, os pastores teriam de subir acima dos 3500m em busca do pasto resistente ao frio da região de Puna, que garante a sobrevivência do gado até a primavera, quando os vales se tornam férteis novamente ${ }^{17}$.

Os dados mostram uma intensa e reiterada ocupação de pastores nas mesmas áreas mais altas das serras. Isto é indicado pela presença de áreas habitacionais em zonas mais baixas, de currais e postos temporários sobre o cordão montanhoso no interior das serras. O espaço, há muito, parece estar dividido por esta atividade do pastoreio que se ordena pela divisão de gênero.

O sistema de pastoreio no vale de Santa María é definido por essas zonas em que os pastores e seus rebanhos se movimentam. Os pastores passam os períodos mais férteis - de outubro a abril - próximos às áreas dos vales e o período do inverno no alto das montanhas. Assim, a área do interior das serras é um espaço masculino, de movimento de rebanhos de animais adultos e seus pastores, assim como a área das casas é onde as mulheres trabalham e onde estão as crianças e os pequenos animais, e onde são feitas as hortas, os pomares e os produtos para serem vendidos.

Por sua vez, a zona serrana não é totalmente livre para ser usada à vontade do pastor. Existem algumas normas que ordenam os movimentos e os lugares, e provavelmente sobre esses lugares há uma maior restrição quando à presença de mulheres. Passeando pelas serras com a filha mais nova de Dom Vicêncio, ela me indica uma direção específica e mostra um ponto, apesar de que aparentemente não há nada indicado. Ela conta que ali é onde, várias vezes, eles já viram uma luz no começo da noite ou no fim da manhã. Ela me explica que essa luz a intriga muito, porque não há casas ou algum posto que possa indicar uma presença. Segundo conta, ela nunca foi até o lugar, porém o seu pai já foi várias vezes e nunca encontrou nada - não há indicações de alguém ter estado acampado -. Diz que Dom Vicêncio acredita que a luz saia de dentro da pedra, pois por toda a zona há locais onde existem essas luzes.

Este relato indica que há locais que são considerados perigosos nos percursos da serra, especialmente para as mulheres quando passeiam com as crianças, e esses locais

\footnotetext{
${ }^{17}$ Dados específicos sobre pastagens, tipos de plantas e características das zonas ecológicas estão descritas no capítulo 1.
} 
devem ser evitados piamente. Relatos desses locais de perigo são comuns entre os pastores e indicam geralmente a presença de ruinas arqueológicas, material arqueológico e, quase sempre, acompanhados de situações inexplicáveis como a luz que sai do solo ou mesmo ventos nascendo nas pedras.

Nas serras, os pastores fazem uso de caminhos e locais de parada que, muitas vezes, são reconstruções de antigos postos. Como o conhecimento do espaço aqui é passado de geração a geração, existe uma constante retomada do mesmo. Dentro dos percursos, reconhecem alguns locais como perigosos e não os acessam, mantendo-se no caminho sabe-se que se está seguindo por um trajeto seguro, no qual podem transitar sempre que necessário em busca de olhos d'água.

Apesar de que é possível observar algumas mudanças neste comportamento (como no caso de Guadalupe), há uma recorrência: o pastoreio ocorre no interior das serras e este é o espaço dos animais machos adultos (sejam eles humanos ou outros animais do pastoreio). Por conta disto, observamos uma maior quantidade de caminhos e rotas de pastoreio que levam ao alto das serras e também grande parte dos currais e das áreas de pastagem estão nas partes altas das serras.

No que constitui o imaginário do pastor, ao perguntar sobre as características do pastoreio, a serra é o principal indicador que eles expõem. Ao perguntar a Don Vicêncio onde estão os pastores a resposta é rápida, “ahhh estão por lá, na serra... por lá... tá vendo?". A resposta parece óbvia para este senhor de mais de oitenta anos. É claro que os pastores estão nas serras, pois é lá que estão os animais e o seu alimento, ainda quando é verão, a serra é o marcador espacial dessa atividade. Isso acontece pelo vai-e-vem dos pastores e seus rebanhos pelos caminhos e lugares dessas regiões mais elevadas. Os caminhos e os locais também são marcadores dessa domesticação dessa paisagem da área das serras, assim como os animais e as plantas. Por isso, o tipo de animal que integra o rebanho é adaptável à variabilidade do ambiente em questão.

\section{5 - O que é ser pastor?}

$\mathrm{Na}$ atividade pastoril, o animal é o elemento central, integrado às pessoas e ao ambiente. A relação entre as partes que constituem um sistema pastoril é complexa, as partes são interdependentes entre si. Por um lado, o pastoreio é uma estratégia de 
aproximação a um determinado ambiente e de utilização dos seus recursos, é uma especialização, que permite tirar vantagem das inconstâncias da vegetação e dos ciclos regulares de migração. Complementarmente, quando se fala de pastoreio tradicional, é imprescindível compreender que se está lidando com um modo de percepção tanto quanto um modo de produção. Portanto, os pastores se reconhecem entre eles e se definem como tal, eles são aqueles que, mesmo num modo mais sedentário, seu plano de ação resumese a pastorear (Markakis: 2004: 14).

Um dos distintivos dos pastores é o interesse pelo rebanho acima de outros interesses. Isto fica muito claro logo nas primeiras páginas de "Os Nuer” (Evans-Pritchard 2011), quando o autor destaca o interesse - ou quase que a obsessão - deste grupo de pastores em relação ao gado. $\mathrm{O}$ autor destaca que todas as atividades sociais - incluindo a nomeação das pessoas, as atividades rituais e cotidianas, as lutas com grupos vizinhos e as disputas por territórios e produtos - dizem respeito ao gado. Por sua vez, o interesse ou total desinteresse por outros grupos vizinhos também responde à prerrogativa de serem ou não pastores (Evas-Pritchard: 2011: 23-59).

Ainda que em menor medida que os Nuer, o interesse pelo rebanho também é central entre os pastores em Santa María. O rebanho é o centro de todas as atividades de um grupo pastor, se não diretamente, pode-se ter certeza que o é indiretamente. Compreender todos os elementos da realidade destes grupos em Santa María implica também conhecer a relação com os animais.

Isso é perceptível, por exemplo, nas histórias que conta Guadalupe. Quando ela fala dos animais, coloca-os em lugar central. Os animais são fonte de renda, portanto subsistência, além do mais, os animais estão presentes nas atividades do dia-a-dia, por isso criam essa relação de afeição. Tudo o que Guadalupe vê na paisagem, ela relaciona com a criação de animais. Por exemplo, andando por entre umas ruinas para fazer coleta, ela se atém a me mostrar um conjunto de currais (que fazem parte do conjunto de recintos das ruínas), ela me indica que primeiro há uns currais bem grandes e logo, um pouco à frente, há um grande curral com pequenos associados. Guadalupe diz que seria para pôr os animais pequenos e separar aqueles que estão sendo amamentados para, ordenhar as mães.

O mesmo ocorre com Dom Vicêncio ou Dom Yucra, ou mesmo com os filhos de Dom Vicêncio. Toda conversa, assunto ou obrigação, tudo está relacionado aos animais. 
E se tudo está relacionado com os animais, para os pastores, tudo está diretamente relacionado com o movimento pelas serras em busca de pastagens e água. Isto porque os animais e os humanos precisam das plantas e da água e, consequentemente, das serras, que é onde é possível encontrar estes elementos.

A relação com os animais e com as outras pessoas que também criam animais é tão intensa e importante na vida destes pastores que Dom Yucra diz que se sente muito mal quando adentra as regiões de Puna. Diz que lhe dói a cabeça, tem tonturas e sente mal do estômago. Ainda assim, este senhor afirma que uma vez ao ano sempre acessa as regiões mais altas para participar de uma festa tradicional que tem como elemento central os animais do rebanho. Ele conta que fazem apresentações e dão prêmios para os animais mais bonitos e que ele gosta muito de ir.

Isso demonstra que a relação com o gado ultrapassa os níveis da simples criação para a venda. $\mathrm{O}$ ser pastor implica diretamente uma percepção de mundo do ponto de vista do animal que se pastoreia. Por isso, compreender as adaptações dos humanos junto aos animais e ao ambiente é fundamental, assim como é essencial conhecer as relações que se estabeleceram nestes vales Calchaquíes com a domesticação. Inclusive, é possível que esta relação entre a área serrana e o pastoreio venha do processo de domesticação dos primeiros camelídeos andinos. A presença de camelídeos considerados domésticos, como as lhamas, nos registros arqueológicos da região, permite admitir uma série de hipóteses sobre o assunto, inclusive sobre os hábitos dos pastores atuais.

Desta forma, o pastoreio é um modo de produção ancestral, que implica em um processo de adaptação a um determinado ambiente, ocupando nichos ecológicos diferentes. A unidade de produção pastoril é a unidade familiar, a divisão de trabalho está contida dentro dessa unidade e baseia-se tanto no gênero como na idade. O papel do animal integra todas as relações sociais, porque o pastoreio tradicional é um modo de vida que integra a subsistência e a apreensão do mundo (Markakis: 2004: 08).

Para compreender o pastoreio, há que entender duas questões que são centrais:

1-) A domesticação;

2-) O papel das instituições internas. 


\section{1 - Sobre a domesticação animal}

Os patamares heterogêneos andinos são significativamente importantes, pois criam diferentes nichos de fauna e flora que se desenvolvem em uma sucessão de altitudes. A exploração de diferentes espaços ecológicos é algo que está presente entre humanos e animais. Em resposta ao ambiente, os animais herbívoros - consequentemente acompanhados pelos carnívoros - fazem uso da distinta sazonalidade de crescimento e dispersão da flora nestes altiplanos andinos. Este padrão de comportamento móvel permite ao herbívoro acessar a vegetação nova e manter um nível ótimo de nutrientes ingeridos por um período prolongado (Baner et al 2011; Jozén et al 2011).

Fundamental para entender o que é ser pastor é compreender as relações que se estabelecem dos humanos para o animal e o comportamento do animal em relação às pessoas. Assim, no emaranhado dessas relações de mão dupla, existem três temas predominantes: 1) o processo e o significado da domesticação; 2) a relação do movimento natural dos animais; 3 ) as práticas do pastoreio no passado e no presente.

\subsection{1 - O significado e o possível processo da domesticação}

A existência de animais nas sociedades (predação, pastoreio, contribuição) é constante na história humana. Por anos, os humanos têm-se movimentado levando consigo animais, rebanhos, parasitas e plantas. Os animais silvestres foram seguidos e caçados, assim como animais domésticos acompanharam os humanos. A maioria dos rebanhos talvez já foi presa de caça e determinadas circunstâncias e o gerenciamento das estratégias podem ter promovido um manejo e uma domesticação (Clutton-Brock 2015).

Esta relação entre a caça e a domesticação é uma das relações que se coloca sobre a relação de animais silvestres que passam a ser pastoreados e integrar um rebanho (Clutton-Brock 2015b; Bökönyi 2015; Zeder 2012; Cassidy 2007; Ingold 1988; Botterna 2015). Talvez, a habilidade por parte do animal de prever o comportamento humano pode ter dificultado a sua caça e ter dado início a um processo de domesticação. O animal se transformaria, aos poucos, de algo estranho a um ser familiar em vários estágios intermediários (Ingold 1988; Botterna 2015). 
Esse processo de caçar os animais até pastoreá-los pode parecer um pequeno passo, porém é um verdadeiro abismo. Ainda hoje tem-se pouca compreensão dos processos reais que levaram aos resultados atuais (Clutton-Brock 2015b). Sobre o conceito da domesticação ainda não há unanimidade sobre o assunto, existem diferentes perspectivas, algumas colocam os humanos como parceiros dominantes ou em relação de vantagem, outras priorizam o mutualismo biológico onde as duas partes se beneficiam. Os autores concordam que é um processo longo e contínuo, o caminho para a domesticação de animais é intensamente variável e contingente em relação aos parâmetros biológicos e culturais (Zeder 2012; Marín et al 2007).

No presente trabalho, diante dos dados etnográficos, é difícil não pensar em um processo de mão dupla, uma simbiose entre criaturas que por longos períodos coexistiram propiciando cooperação e trocas além de propriedade e controle, e como consequência não obrigatória - do processo de domesticação estaria a formação de rebanhos. Nem todo animal em contato com humanos é domesticado, talvez porque a domesticação implique na conexão entre características especiais dos animais e adaptabilidade dos dois parceiros. A domesticação é uma simbiose que necessita, no mínimo, dois parceiros: por um lado o humano influenciando o animal e este, por sua vez, jogando um importante papel também, influenciando os humanos (Bökönyi 2015).

Por sua vez, a domesticação é um processo gradual e dinâmico que implica em investimento humano sobre os indivíduos domesticados, alterando o ambiente, cuidando dos ciclos de reprodução, proteção contra predadores e intervenção nos ciclos reprodutivos. No processo da domesticação, observam-se transformações e mudanças morfológicas que são produzidas nos animais, onde o grupo selecionado separa-se das outras espécies selvagens, passando a apresentar uma aparência uniforme como subespécies (Clutton-Brock 2015b; Zeder 2012). Esta condição, que viria em um segundo momento do processo de domesticação, é questionada por alguns autores, inclusive no caso das lhamas, se as lhamas são realmente o descendente domesticado dos guanacos selvagens, deveriam apresentar diferenças morfológicas nas ossadas, afirma Yacobaccio e Vilá (2013). Porém, esta não é uma discussão para o momento, ainda mais, porque diante das diferentes perspectivas exploradas quando o assunto é domesticação animal, diversas variantes opostas se apresentam (ver Clutton-Brock 2015). 
A domesticação animal está totalmente relacionada com as características comportamentais dos animais, identificar e estudar esse comportamento pode contribuir para elucidar o processo de domesticação e a influência nos humanos. Os humanos apresentam uma capacidade de comunicação bem-sucedida, somos capazes de desenvolver relações muito próximas com outros animais. Essa comunicação provavelmente foi a base dos processos de domesticação (Clutton-Brock 2015).

A domesticação implica um conhecimento e trabalho contínuo sobre o rebanho. Ainda quando o humano se beneficia, o rebanho também pode se beneficiar dessa associação (Ingold 1988). Neste processo, os humanos dispendem tempo e energia para com os animais do rebanho (adaptando-se, comunicando-se e inclusive modificando alguns comportamentos etc.). Por sua vez, os animais passam a envolver uma complexa rede metafórica e significativa, que vai desde o status social à representação dos animais no âmbito do imaginário e do religioso (Jennbert 2012). Ao mesmo tempo em que o humano apresenta um gasto de energia, a priori, ele tem um ganho a posteriori, pois os animais herbívoros podem ter um aproveitamento maior dos nutrientes que humanos. Com isto há um maior aproveitamento de zonas marginais, como é o caso de Santa María.

A mudança numa concepção do que se entende por natureza abarca essa questão da cooperação como uma resposta frutífera ao uso de um ambiente e seus recursos. A domesticação, como processo biológico e cultural, somente toma forma quando o animal é incorporado à estrutura social do grupo humano; assim, não é unicamente o controle de um rebanho que implica na domesticação, é necessário haver um desenvolvimento nas relações entre os humanos e os animais que vai além da subsistência básica de cada um deles, também implica em sobrevivência, adaptabilidade, relacionamento e na construção de uma série de redes sociais, políticas e religiosas (Morphy 2015; Jennbert 2012; Kardulias 2015).

Abordar estas discussões por separado não permite que se dê a devida importância ao processo de domesticação de um ambiente como um todo. A relação entre humanos e o animal é caracterizada pela ordem de pastor e rebanho, porém não é puramente econômica, existe uma cooperação entre humanos e animais que estabelece relação de afinidade. Isto implica em uma relação dinâmica entre as partes, ordenada de acordo: a) às necessidades dos animais; b) às necessidades do homem; c) à capacidade de resposta a certas intervenções do ambiente (Yacobaccio e Vilá 2013). 
Nesta aprendizagem, é necessário ter clareza quanto aos padrões de alimentação, territorialidade, relação entre indivíduos e a reprodução dos animais que exigem do humano e do animal uma dinâmica conjunta de apreender novamente o ambiente. Recriase e se reaprende o ecossistema ${ }^{18}$ que agora o ser humano integra de forma ativa junto a outros organismos.

Quanto à adaptação animal no pastoreio em geral, o processo dinâmico que gera afinidade é baseado em relações positivas e negativas passadas que influenciam as interações. Algumas ações reforçam a relação entre o humano e o animal de maneira positiva, estas facilitam o manejo e as monitorias dos mesmos. Estas ações positivas como alimentá-los, tratar com delicadeza e carinho etc. - contribuem para estabelecer uma relação de confiança e dissipar o medo do animal como presa (Cobo e Romero 2012).

Estudos com bovinos têm demonstrado que estes herbívoros generalizam a resposta em relação ao homem, assim a qualidade da relação humano/animal tem a ver com o grau de satisfação e segurança do tratador dos animais. Uma relação humano/animal negativa pode afetar a produtividade e a inocuidade da carne. $\mathrm{O}$ medo que o herbívoro sente parece estar associado à relação predatória que ativa os eixos hipotalâmico-pituitário-adrenal e o simpático-adrenal-medular. Esta ativação ocorre rapidamente, gerando o que chamam de "crise de emergência", que consiste na ativação do sistema nervoso autônomo, e resulta na secreção de catecolaminas (principalmente adrenalina e noradrenalina), provocando o aumento da frequência cardíaca, do vaso constritor periférico, aumento da glicemia, dilatação das pupilas, hiperventilação e aumento do volume sanguíneo. Em outras palavras, a "crise de emergência" prepara o animal para fugir e lutar. Posteriormente, o organismo tenta adaptar-se e enfrentar os fatores que percebe como ameaça, se estes fatores persistem o animal se vê incapaz de superar o estresse, o qual passa a ser crônico. Esta condição constante implicaria diversos transtornos, inclusive uma morte prematura (Cobo e Romero 2012).

Isto demonstra que a domesticação condiciona uma relação entre o pastor e seus animais muito mais profunda, em razão da compreensão do comportamento. Seja consciente ou inconsciente, a relação que se estabelece implica a sobrevivência e melhor qualidade econômica da venda do animal a posteriori, e, por sua vez, permite aos

\footnotetext{
${ }^{18} \mathrm{~A}$ escolha pelo uso do termo ecossistema é para ter uma noção mais ampla do contexto, pois exige pensar em escalas, sendo o ambiente a integração regional e a interação com o mundo global. Assim, não é apenas o uso da paisagem, mas o uso integrado às respostas dadas pela paisagem.
} 
humanos ter um aproveitamento nutricional e energético neste ambiente que não seriam capazes sem esta atividade.

Considerando que todos os elementos do sistema pastoril estão interligados, o animal continua sendo o elemento central. Os humanos necessitam dos animais para acessar os benefícios do ambiente. Com o tempo e a domesticação, os animais também passam a necessitar dos humanos, pois, de certa forma, também são socializados neste processo.

Esta condição relacional que se estabelece entre humanos, plantas, animais e o próprio ambiente no qual interagem, permite observar como todos estes elementos existem e se movimentam continuamente uns para os outros no ambiente que os rodeia. O movimento que animais e homens estão fazendo, seguindo os diversos ciclos de vida que transformam permite que se estabeleçam linhas de interação. Nas serras, caminhos e trilhas que são traçados pelo pastoreio, integram-se e transformam-se cada um destes elementos que criam o emaranhado de coisas vivas que observamos, como o sistema pastoril em Santa María.

Para entender a relação entre o que as lhamas demarcaram nas serras dos vales Calchaquíes e o que as cabras estão fazendo hoje em dia, é preciso entender a domesticação, que, por sua vez, implica em entender o comportamento animal e a formação de rebanhos. Esta domesticação acontece em diversas direções, por um lado, os homens domesticam animais, plantas e ambiente, por outros os animais e o ambiente domesticam o homem e assim por diante.

\subsection{2 - Alguns apontamentos sobre as relações entre animais e humanos nestes vales}

O nomadismo sazonal e a migração em mamíferos terrestres estão presentes em todos os continentes, e a maioria a apresentar este comportamento são os herbívoros. Um dos tipos de animais nômades são as espécies que habitam ambientes de montanhas, por conta da sazonalidade do crescimento da vegetação, que é causa dos regimes de chuvas e das temperaturas que oscilam fortemente. Em regiões montanhosas, ainda há o agravante da altitude que, associadas à estação fria, produz invernos que se prolongam, retrasando

o derretimento da neve, e, consequentemente, retrasando o crescimento da vegetação de verão nas áreas altas em relação às próximas aos vales. Portanto, os herbívoros terrestres 
exibem turnos sazonais de movimento e acordo a esta sazonalidade da vegetação (Baner et al 2011; Jozén et al 2011).

Tanto os camelídeos selvagens - vicunhas e guanacos - quanto aqueles considerados domesticados - as lhamas - apresentam um comportamento complexo em relação à ocupação e à delimitação de um território. Os locais de dormir são fixos e geralmente em áreas elevadas, estes animais voltam diariamente aos mesmos lugares no final de cada dia. As áreas são reutilizadas pelo grupo familiar por anos. Principalmente as lhamas, apresentam um comportamento transumante, estes animais retornam anualmente aos mesmos locais (Tomka 1992).

A área de descanso destes animais é facilmente identificada, pois o perímetro é demarcado com o estrume, criando uma barreira de reconhecimento. Assim, mesmo saindo para as pastagens, os camelídeos retornam aos seus locais de descanso diariamente. $\mathrm{O}$ comportamento transumante é mais fácil de identificar entre as lhamas, no período do verão, as áreas de descanso e alimentação se transferem às margens dos vales, comportamento que é associado ao momento do nascimento das crias. Estes animais acompanham o crescimento das gramíneas nos períodos úmidos e fazem uso das pastagens resistentes das áreas altas de Puna, que resistem ao inverno (Tomka 1992).

Este padrão de comportamento dos camelídeos possivelmente marcou o uso do espaço pelos humanos para o pastoreio, que apresentam esse mesmo padrão de uso do espaço na relação inverno/verão, ainda quando camelídeos como as lhamas já não integram os rebanhos. A domesticação desse ambiente resultou numa paisagem marcada por uma série de rotas de pastoreio e currais no interior das serras.

As rotas ligam locais, ao redor dos quais, faz-se visível a persistência de uma vegetação arbustiva que difere dos pastos que se veem na montanha. Durante o movimento, o pastor vai cortando plantas indesejadas, deixando as que considera interessantes e assim "limpando" o caminho. O estrume dos animais está presente em todo o percurso e em grandes quantidades nos currais e arredores. Os alimentam-se e defecam, polinizando com as sementes das plantas que ingeriram. Desta forma, pastor e rebanho vão domesticando esse ambiente.

A transformação ocorre na permanência do uso da paisagem, nos locais e trilhas marcados por uma ação de limpeza e germinação de certas sementes. A consequência 
desta ação - seja consciente ou inconsciente - é o enriquecimento da concentração de plantas utilizadas. Assim, cada espaço é uma marcação feita pelo homem no ambiente, definido por uma intervenção de baixa escala. Este manejo de baixa intensidade muitas vezes é difícil de ser distinguido, porém, na ação constante do processo de apropriação por meio da atividade humana, o lugar é constantemente socializado e apreendido (Neves e Petersen 2005; Politis 1996)

O manejo é um controle do ambiente, ainda quando não há uma intervenção intensa existe a ação humana. Em Santa María, o uso do ambiente transforma e integra o território, criando uma paisagem conhecida e identificada. Cada caminho e cada local são ações exercidas a esse ambiente, criando assim uma paisagem reconhecida socioculturalmente, e imprimindo significado simbólico e material. Assim, animais e plantas são transformados e integrados à paisagem a partir das percepções dos seres humanos. Estas partes funcionam juntas e integram o sistema que toma lugar na região serrana do vale de Santa María.

Resumidamente, o hábito deste tipo de ungulado de cascos pares ${ }^{19}$ está relacionado às regiões serranas, pois permanece nas áreas mais elevadas a maior parte do ano, apenas descendo às zonas dos vales nos períodos do verão para ter as crias (Tomka 1992). Desta forma, os hábitos alimentares desses animais exigem o movimento por áreas férteis ao longo do ano, conforme avança o inverno, são obrigados a alcançar as zonas mais altas em busca de pastagens resistentes ao frio.

A relação das lhamas com as áreas que integram o seu território é tão forte que dificilmente um animal adulto se adaptará a um território novo. Estes animais se movimentam diariamente para as áreas de alimentação durante o dia e de volta à área de dormir ao entardecer. Desta forma, cada grupo - ou rebanho - apresenta o seu próprio lugar de alimentação e resguardo (Tomka 1992). Todas estas características do rebanho de lhamas promovem uma aproximação específica com o espaço e consequentemente “domesticaram” a paisagem. A disposição das estruturas e o hábito dos pastores também parecem responder a esta lógica da organização territorial das lhamas.

\footnotetext{
${ }^{19}$ Os ungulados eram uma divisão dos mamíferos que compreendiam os animais de cascos. Hoje, esta classificação dividiu-se da seguinte forma: Perissodáctila (ungulados de cascos ímpares); Artiodátila (ungulados de cascos pares, entre os que se destacam os camelídeos e as cabras); Cetácea (baleias, golfinhos e Sirena); Proboscídea (elefantes); Hyracoidea (híraxes); além de outras ordens já extintas.
} 
Como os camelídeos são territoriais, não necessitam ser fechados ou impedidos de sair do que consideram o seu território. Portanto, os currais no vale de Santa María são de paredes baixas e muitos não apresentam porteiras. Outra situação comum é a inexistência de currais, considerando que os animais se recolhem sozinhos. Esta condição é pouco usual no universo do pastoreio. Ao se observar um curral de vacas em uma fazendo na área dos pampas na Argentina, é possível perceber a altura dos aramados e porteiras, construídos assim para impossibilitar o animal de deixar o curral sem a presença do pastor. Esta mesma condição de encerramento é plausível entre as populações pastoras da África e da Mongólia, onde os animais são restringidos por currais e cercas.

Nestas serras, de acordo com o que conta Guadalupe, os currais tinham mais função de proteção contra os predadores do que a função de impossibilitar os animais de escapar. Os currais também eram utilizados para determinadas atividades, como manter os animais juntos para tosquiá-los, para separar os mais jovens dos adultos ou ainda as fêmeas prenhas dos machos. O fato é que, tanto os currais da atualidade como aqueles considerados ruínas arqueológicas, apresentam paredes simples, sem muita resistência, e, na sua maioria, observam-se vários recintos associados.

A relação com o espaço é tão intensa que, inclusive entre aqueles pastores que hoje criam cabras, como cria Don Vicêncio - ou criaram o seu pai e o seu sogro -, a apreensão da paisagem e uso da terra e seus recursos dá-se da mesma forma que o fazem as lhamas habitualmente. Isto permite inferir que, na relação entre homens, animais e as serras há uma integração entre as partes que ultrapassa apenas o funcional. A paisagem também está exercendo uma agência para com os homens e animais no mesmo nível que estes a exercem sobre a paisagem. Portanto, mesmo criando cabras, os pastores permanecem no interior das serras, onde os animais pastam por horas a fio sem a presença dos homens para organizá-los ou guia-los, e ainda se recolhem nos mesmos locais com currais de paredes baixas, como é habitual dos camelídeos.

Várias vezes, quando estava na casa de Dom Vicêncio e Dona Maria, pude ver as cabras voltando sozinhas ao entardecer e se recolherem no seu lugar de descanso habitual. Em uma manhã que passei por ali bem cedo, com os primeiros raios de sol, pude ver as cabras ainda recostadas todas juntas em um círculo, como se uma cerca imaginária as confinasse nesse local. 


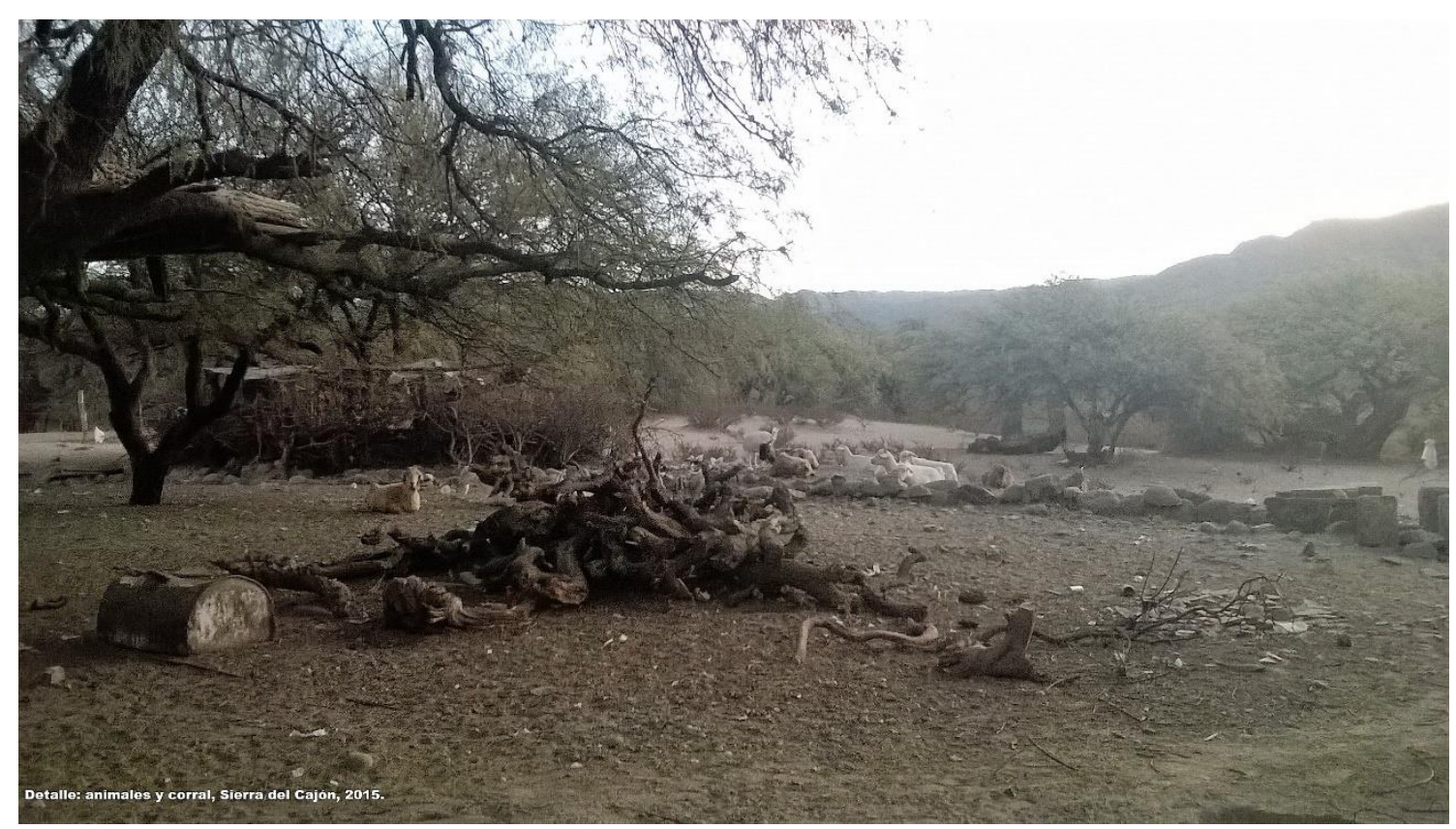

Figura 18 - Curral em Santa María. Imagem mostrando as cabras todas juntas no início da manhã, com um curral marcado por pedras amontoadas de baixa altura.

E talvez seja por isso que a visão das serras hoje é a de muitas cabras pastando livres pela área serrana, entre os caminhos e currais, os quais de dia estão sempre vazios, mas apresentam uma grande quantidade de estrume desses animais, atestando que são utilizados. Como foi ressaltado anteriormente, a atividade pastoril na área serrana não é algo exclusivamente dos dias atuais, é possível atestar a antiguidade dos pastores nos Andes apenas com olhar para essa paisagem. Conforme se avança para o interior das serras, identificam-se diversas estruturas utilizadas na atividade pastoril, são currais, áreas de descanso e resguardo, habitação dos pastores, os caminhos e vários animais (sejam cabras, camelídeos selvagens ou domésticos, burros ou cachorros e gatos).

Assim, o interior das serras continua sendo um local de pastoreio. A mobilidade entre o inverno no interior das serras, fazendo uso dos pastos de altura, e o verão nas áreas próximas ao rio para o momento de procriação é parte deste sistema pastoril de Santa María, ainda quando há pelo menos duas gerações se criam cabras e não mais lhamas. Tal persistência obriga a repensar as relações puramente funcionais de um sistema produtivo. É possível inferir que todas as partes deste sistema funcionam - e devem funcionar juntas, mas não apenas como partes, ou pontos inertes em linhas, as partes do sistema pastoril formam uma teia que existe dentro de um ambiente. 
Nesta teia pastoril os pontos são a textura do entrelaçado na trama de linhas. Cada um destes elementos apresenta um papel indiscutível na ordenação e no funcionamento do sistema pastoril em Santa María, que está em constante transformação e movimento, atestando a existência dessa longa temporalidade de ação nesse espaço que envolve plantas, animais, humanos, currais, caminhos, pedras e muitos outros pontos. Nessa teia complexa, a serra não é um espaço finalizado, é uma reunião de vidas que a habitam e existem nela, é o lugar onde as várias vidas se entrelaçam.

\section{2 - Sobre as instituições pastoris tradicionais nestes vales}

A organização do pastoril tradicional gerencia regras e práticas que há muito estão em vigência, juntamente às ordens novas de mercados, políticas públicas e ordem nacional (Sylla 1995). O pastoreio vale-se do comportamento oportunista e da mobilidade como a melhor forma de gerenciar os recursos dos ambientes (principalmente em ambientes incertos), assim as regras e práticas pastoris respondem a uma economia organizada e suportada cotidianamente, principalmente em relação aos recursos naturais.

Existem dois tipos de instituições que regem a administração pastoril: 1) Instituições formais- são elementos da constituição nacional e da legislação que lidam com questões da propriedade privada e o uso da terra e direitos de proprietário sobre os animais; 2) Instituições informais- são maneiras habituais de reger as coisas; ordenam o uso das pastagens, acesso aos recursos e capacidade animal, trocas, convenções sociais (como os casamentos, as alianças e resolução de conflitos). As administrações pastoris tendem a exibir uma larga flexibilidade em relação às dinâmicas de mudanças, integrando as formas tradicionais com as institucionais (Swift 1995).

Neste ponto, o que interessa é conhecer essa organização pastoril tradicional, a qual pode apresentar um número de aspectos comuns que influenciam o processo da construção de instituições. Os aspectos das organizações pastoris tradicionais podem ser compreendidos a partir dos seguintes elementos: a) o nível de organização; b) o tamanho das organizações pastoris; c) mecanismos regulatórios e de reforço; d) instituições criadas de cima para baixo e de baixo para cima. Estes aspectos regulamentam as relações com o tamanho do rebanho, usos das áreas de pastagens e locais de água, distribuição de tarefas, principalmente no que concerne às necessidades externas (Sylla 1995). 
Talvez compreender as instituições tradicionais pastoris seja uma das questões mais complexas - e difíceis - de se observar em campo. As práticas do pastoreio, assim como qualquer outro aspecto da vida cotidiana, integram a sobrevivência básica, elementos sociais e simbolicamente construídos, associando o comportamento tradicional às exigências institucionais dos Estados, fazendo que as instituições tradicionais estejam em constante atualização.

Sobre o nível de organização (a) destas instituições tradicionais, pouco se tem a acrescentar, uma vez que é difícil defini-lo. Os pastores apresentam uma inter-relação e um conhecimento das normas e regras que regem, principalmente, sobre as áreas de serra. As normas são do conhecimento de todos, homens adultos, mulheres e crianças e tendem a ser seguidas.

O tamanho da organização pastoril (b) responde diretamente ao núcleo familiar, porém a ordenação do sistema exige uma rede de relações que extrapola a família e integra o que viriam a ser os vizinhos. Quando eles falam de vizinhos, não se referem unicamente àquelas pessoas das quais as casas fazem divisas, mas são aqueles que integram uma mesma área. Entre os vizinhos existe uma troca de suporte, informações e produtos e os caminhos são compartilhados por isso é possível atravessar cercados e porteiras.

Esta rede de relações entre os vizinhos também implica no mecanismo de regulação e reforço dos pastores (c), espera-se certo tipo de comportamento entre os pastores, respeito sobre os animais, recursos e áreas alheias. Os pastores conhecem o limite entre o seu rebanho e o rebanho alheio, não ingressando em áreas que, no momento, estão sendo utilizadas por outro pastor, assim como um cuidado com o roubo de animais. Porém, não observei diretamente estas informações, os dados me foram contados, podendo existir uma diferença entre a prática e o que se fala.

A organização interna das instituições pastoris (d) é relativa à rede de reciprocidade entre vizinhos, aparentam responder a uma ordem etária, pela qual os homens mais velhos apresentam um certo respeito dentro do grupo e também dentro do núcleo familiar. Porém, estas relações estão praticamente dissolvidas nas instituições externas e pouco se fala sobre instituições tradicionais.

Apesar da dificuldade em observar a ordem das instituições, as organizações pastoris podem responder às necessidades modernas e tradicionais ao mesmo tempo. Os 
desgastes apresentam-se quando as instituições externas fazem uso de uma força de cima para baixo e impõem mudanças que afetam tanto a sobrevivência das pessoas quanto a permanência do sistema. Uma das questões fundamentais destes grupos é a questão da privatização das terras e acesso aos recursos. 


\section{3 - SOBRE MOVIMENTOS E ASSENTAMENTOS. A \\ mobilidade dos pastores}

No capítulo anterior, foram apresentados os elementos que definem a estrutura do sistema pastoril de Santa María, porém ainda faltou explicitar uma das questões fundamentais desta forma de pastoreio: a mobilidade.

Ao decorrer deste capítulo, se irá discorrer sobre as formas de mobilidade dos pastores em Santa María e sobre as consequências desse comportamento na aproximação do espaço habitado.

\section{1 - A mobilidade no pastoreio}

No capítulo anterior, fez-se uma tentativa de definição do pastoreio em Santa María a partir da estrutura do sistema pastoril. Diante do observado é possível afirmar que se está lidando com um sistema pastoril tradicional, no qual se faz uso de pastagens naturais e das características andinas de diferentes nichos ecológicos de acordo com a altitude e a presença/ausência de humidade. Desta forma, destacou-se um sistema móvel, com a presença de produtos externos, frutos da troca de produtos pastoris, e com rebanhos pouco variados de cabras ou ovelhas e lhamas, com a presença de burros como animais de carga.

Resta pensar em que consiste essa mobilidade pastoril, principalmente porque existe uma grande variabilidade de formas de movimentar-se entre as populações pastoras no mundo todo. As categorizações mais comuns do pastoreio referentes à mobilidade

propõem variações de acordo com o grau: altamente nômades, transumantes e sedentários. Estas variações levam a diferenças na aproximação com o espaço, na forma como ele é construído, apreendido e habitado. 
Para dar início à discussão, é importante destacar que os pastores consideram a paisagem desde duas perspectivas: a humana e a do animal. Considera-se a necessidade dos dois ao avaliar a terra e os recursos de maneira dinâmica e necessariamente flexível. Quando se considera os ambientes marginais nos quais se desenvolve o pastoreio, é importante perceber que estes grupos mantêm várias opções abertas. Assim, no cálculo ecológico, os pastores devem identificar as melhores combinações de localização e tempo em um ambiente específico para maximizar os benefícios dos animais (qualidade de pastagens, água e temperatura) e minimizar as influências prejudiciais. Todas estas questões são levadas em conta quando se toma a decisão de quando mover-se e para onde mover-se, e implicam na diferença entre o pastoreio vertical e o pastoreio horizontal (Kardulias 2015).

Assim, os registros etnográficos indicam que existe uma condição ótima de relação entre o ambiente e o movimento, porém, não se pode considerar que os grupos nômades se movimentam unicamente considerando necessidades ambientais. Vários registros etnográficos mostram que os pastores apresentam uma grande diversidade nas estratégias de adaptação e especialização nas suas várias atividades econômicas, e que estas são parte de uma estrutura sociocultural (Frachetti 2008; David e Kramer: 2001: 266-270).

O pastoreio, portanto, é um fenômeno multifacetário com várias definições possíveis que envolve tanto questões ambientais como padrões variáveis socioeconômicas (Holl 1998; Odell 1994). Por sua vez, novas propostas vêm se desenvolvendo, visando contemplar todos os âmbitos que envolvem a mobilidade, como a capacidade e a necessidade de se movimentar de um lugar a outro lugar, sem considerar unicamente um viés linear e fixo. Portanto, devem ser consideradas as motivações, dando ênfase à fluidez, à tomada de decisões e à agência em todo o processo, ou seja, no ciclo completo que é traçado pelo grupo nômade (McCabe 2004).

A parte andina do Noroeste Argentino, tanto o altiplano como a puna, é uma região que vai do semiárido ao árido e o pastoreio junto à economia vertical (característica dos Andes) é um mecanismo efetivo para um melhor aproveitamento dos recursos. Assim a concentração de recursos em regiões determinadas propiciou o desenvolvimento de um "suporte logístico" que, associado às redes de intercâmbio a longa distância, levaram a um posicionamento específico dos pastores frente ao ambiente natural e social desde a perspectiva da mobilidade (Browman 2008). 


\section{2 - Mobilidade e suas características}

Estudos sobre mobilidade abarcam os diversos modos de comportamento dos grupos móveis. São eles: os forrageiros, os caçadores-coletores, os pastores, inclusive, alguns grupos sedentários. Sobre o que é mobilidade, apresenta-se um panorama amplo de definições, pois a dinâmica de ocupação e uso da terra pelos grupos é muito diversificada. De modo geral, os estudos de mobilidade têm apresentado modelos a fim de levantar considerações sobre: distribuição territorial, estrutura e função de sítio, sistema de assentamentos, adaptação aos diversos ambientes, percepção e mapeamento do espaço etc. (Binford 1979; 1980; Frachetti 2008).

Principalmente, entre os anos 1960 e 1980, a ênfase centrou-se em questões como o clima, a fauna e a flora, dando preferência a uma perspectiva mais adaptativa. Estes estudos contribuíram para a divisão em ambientes considerados como "ótimos" ou "benevolentes" (aqueles considerados mais apropriados para um grupo escolher a mobilidade), em contraposição ao que se considerou como ambientes "marginais". Estes estudos presaram por análises mais adaptativas, considerando o viés mais ambiental do período, ainda quando se visava à organização social (Binford 1980; Kelly1983).

$\mathrm{Na}$ atualidade, a mobilidade ainda tem como tema central as respostas comportamentais ao ambiente, porém juntamente considera-se um posicionamento estratégico dos grupos frente ao ambiente e seus recursos. Esta perspectiva implica na percepção de uma maior complexidade na relação entre o homem e a terra, pois existe um monitoramento de recursos de exploração além de planificação e previsão frente a um padrão regional de mobilidade. Generalizando, a mobilidade é definida pela natureza do movimento e pela motivação, sendo a combinação entre o tempo de estadia e o movimento. A natureza do movimento é definida pelas variações de tempo de estadia, pela distância dos acampamentos e pelo tipo de acampamentos. Portanto, o padrão é dado pela combinação de fatores diversos: a) o momento (a sazonalidade e o tempo de permanência); b) a motivação (recursos, identidade, economia) e c) a segmentação (questões de gênero, hierarquia, idade, status etc.) (Wendrich e Barnard 2008).

As estratégias de mobilidade refletem a história do acesso a recursos de uma região, o padrão e mobilidade de um grupo pode ser um indicador das estratégias de uso da terra e seus recursos. As mudanças também podem ser compreendidas como 
indicadores dos elementos que persistem e as novas estratégias implementadas. Para compreender essa história impressa na terra e nos hábitos das pessoas é necessário compreender a mobilidade aliada aos tipos de assentamentos. Tendo em vista que os movimentos sazonais pelo território são apenas uma faceta da organização de um grupo, a mobilidade é afetada pela distribuição dos recursos, a capacidade de captação e instituições que regulam os humanos e seus movimentos.

Desta forma, há duas categorias a serem analisadas, a natureza do movimento e a motivação. Ainda existem outros dois conceitos complementares da mobilidade: a natureza de movimento do grupo e o grau de mobilidade. Portanto, a mobilidade pode ser descrita a partir das variações nessas dimensões da mobilidade residencial e da mobilidade logística. Considerarmos os diferentes fatores e as condições em que cada grupo se move para alcançar os recursos. Estes conceitos podem ser usados como modelo para analisar qualquer tipo de mobilidade, explicitando diferenças de grupo a grupo dentro dessas caracterizações mais amplas.

\section{1 - A natureza do movimento}

Os movimentos sazonais implicam em uma capacidade de planejamento e consideração do tempo, integrando diferentes zonas ecológicas, considerando-se que uma abordagem oportunista e planejada do tempo e do espaço vale mais como resultado final para uma captação complementar dos recursos de um território (Féblot-Augustine 1993). Este tipo de movimento está associado a uma série de fatores que implicam na percepção mental e mapeamento do território, retornando repetidamente aos mesmos lugares.

Para definir o tipo de movimento, dar-se-á destaque à análise por duas categorias: mobilidade residencial e mobilidade logística (Binford 1978). Sendo que, cada uma destas categorias pode existir de maneira independente. A mobilidade logística não necessariamente está associada à mobilidade residencial.

\subsection{1 - Mobilidade Residencial}

A mobilidade residencial caracteriza-se pelo movimento de todo o grupo a outra residência, ou seja, uma residência é abandonada e ocorre uma mudança no local de base residencial. Este tipo de mobilidade implica no movimento completo do grupo desde 
quando um local é abandonado e outro é ocupado. Os diferentes graus do tipo de mobilidade permitem reconhecer e quantificar este movimento. Considera-se: a) o número de residências que se movem por ano; b) distâncias por movimento de residência; c) distância total da mobilidade residencial por ano; d) total de área coberta por ano; e) duração das ocupações dos sítios de inverno.

A mobilidade residencial consiste na mudança de toda a casa residencial. No vale de Santa Maria, os pastores não apresentam mobilidade residencial, a residência é fixa. Ainda quando o pastor se movimenta, na casa residencial permanecem as mulheres, as crianças e as pessoas idosas durante o ciclo anual completo. Os homens adultos e crianças (em idade de acompanhar) podem ausentar-se por breves períodos durante a temporada de inverno, permanecendo fixos na residência o restante do ano.

Uma dúvida que me assolou durante um longo período de pesquisa de campo foi a questão da mudança residencial, se acaso a não mobilidade residencial poderia ser algo atual. Göbel (2012) destaca que, mais ao norte do vale de Santa María, numa região de Jujuy, existem três tipos de residências: os postos temporários, a casa de campo e a casa na cidade. O primeiro tipo, como a designação indica, é apenas para uso temporário, já os outros dois tipos de assentamentos - a casa de campo e da cidade - são utilizadas alternadamente, conforme a necessidade de estar em um lugar ou outro. Neste caso, é possível observar uma mobilidade residencial, ainda que retomem os mesmos locais e estruturas, toda a família se muda para a casa na cidade (quando há festividades ou algum evento que necessitem estar no centro urbano) e depois volta para a casa de campo.

O caso é que a família de Dom Vicêncio destacou ter a casa em Las Mojarras na qual eles vivem até hoje e por um tempo ainda mantiveram a casa do Churqui (onde hoje vive Dom Lorenzo) para passar os finais de semana e temporadas nas férias escolares. Porém, apesar desse caso não foram identificados outros que respondessem ao mesmo padrão.

Conversando com Dona Maria, ela deu-me a entender que a casa de campo que mantiveram no Churqui era como uma casa para ir passear, mas que todos os seus pertences e mobiliário do dia-a-dia permaneceram na casa em Las Mojarras, desde o dia em que se mudaram para lá. Disse que nem o seu pai, nem Dom Vicêncio tiveram outras casas para morar além daquela que a família vivia. 
Portanto, é possível afirmar que, neste período que corresponde às memórias de três gerações de pastores, em Santa María não há indício de mobilidade residencial de nenhum tipo.

\subsection{2 - Mobilidade Logística}

Em contrapartida, o que se observa entre os pastores do vale de Santa María são vários tipos de mobilidade logística. A mobilidade logística caracteriza-se pelo deslocamento de pequenos grupos de uma base residencial a determinadas áreas para a captação de recursos. As características que quantificam a mobilidade logística são: a) distância coberta em uma direção (em mão única); b) a duração total entre a ida e a volta, considerando-se os dias de viagens (Kelly 1983).

Num clima como o do vale de Santa María, as estações do ano são bem demarcadas e as flutuações de temperatura (fruto das grandes altitudes) exigem diferentes estratégias para uma melhor captação dos recursos. O tipo de mobilidade logística varia de acordo com a sazonalidade e variabilidade dos diferentes períodos do ano, por isso observam-se diferentes tipos de movimentos:

\subsection{3 - Distâncias curtas}

As distâncias curtas caracterizam-se por deslocamentos curtos para áreas dentro do perímetro da propriedade ou próximo a ela. Variam de alguns a uma hora de caminhada.

Este movimento refere-se aos primeiros momentos do fim das chuvas. Consiste em soltar os animais pela manhã e buscá-los no final do dia. Muitas vezes, esta é uma atividade das crianças ou das próprias mulheres. $\mathrm{O}$ foco do movimento são os locais com pastagens mais abundantes onde os animais são deixados para se alimentarem.

A filha mais velha de Dom Vicêncio conta que, quando era criança, ela e os primos iam sempre levar e buscar os animais nos períodos de verão. Diz que eles iam e voltavam brincando e que várias vezes foram repreendidos por não prestarem, atenção ao rebanho, pois esta era a obrigação do momento. 
As crianças terem essas pequenas obrigações é muito comum. Quando os rebanhos podem ficar próximo às casas, são os menores que levam os animais ao amanhecer e os buscam ao entardecer. Certa vez, no período do verão, em Las Mojarras observei que as crianças (as maiores de 8 ou 10 anos, não os pequeninos) saiam todo final de tarde e voltavam com as cabras para a propriedade, onde os próprios animais entravam nos currais. As crianças chegavam com o rebanho, andando e comportando-se como um pastor adulto, seguindo os animais pelas laterais, com passadas longas e pequenas varinhas de plantas nas mãos.

Dom Yucra conta que ele, quando criança, sempre ia e voltava buscando e levando os animais nos tempos em que o rebanho ficava mais próximo da casa. Ele diz que a mãe não o mandava, pois que ele sabia a hora certa e já ia buscar os animais onde estivessem. Diz que ia brincando e olhando as coisas e que várias crianças faziam o mesmo. Atualmente, no verão, ele deixa os animais em uma vertente de água muito próxima à casa dele, assim, espera que o sol forte abaixe e vai recolhê-los no curral ao entardecer. A distância que percorre é curta. Não ultrapassa os vinte minutos afirma, mas prefere levar os animais até mais próximo da água do que ter de trazer água para eles na casa.

E assim, estas pequenas distâncias são percorridas duas vezes ao dia. É algo tão habitual que, mesmo quando as crianças não são mandadas, na casa de Dona Maria, foi possível observar que, em determinada hora, as crianças que estavam brincando, já estavam voltando com os animais, nenhuma mãe lhes exigia verbalmente fazer o serviço.

Estas pequenas obrigações que fazem parte do universo infantil também permitem que os adultos tenham um maior tempo livre para se ocuparem de outro tipo de atividade. Estas atividades extras podem ser obrigações na cidade, concertos ou construções necessárias e várias outras atividades que exigem um maior tempo da pessoa ou, ainda, algum tipo de cultivo (como abóbora, vagem, alguns tipos de batata, algumas variedades de milho, pimenta, entre outros). Os adultos também se empregam em algum trabalho temporário, inclusive longe da casa.

\subsection{4 - Distâncias intermediárias}


Caracterizam-se por deslocamentos mais longos, fora do perímetro da área residencial que adentram o interior das serras, a distância coberta varia em algumas horas de caminhadas ou distâncias de até um dia, ou mais de um dia.

A prática ainda implica em levar os animais até uma área considerada apta para suprir as necessidades do rebanho e logo de horas ou até dias voltar ao local para recolhêlos. Os animais ficam no interior das serras em currais construídos e reconstruídos para que se recolham à noite. Muitas vezes, os animais se resguardam sozinhos, sem a necessidade de ter a presença do pastor em tempo integral. Nem sempre o pastor necessita estar presente de manhã ou de noite, no geral, os animais ficam soltos por alguns dias enquanto os pastores se dedicam a outras coisas.

Dom Lorenzo faz muito isto, ele leva os animais a áreas que tenham boas pastagens e água e se dedica a fazer alguma outra atividade, cuida de cultivos, concertos eventuais, e inclusive ele aproveita para ir até a cidade cuidar de trâmites administrativos e/ou compras necessárias.

Quando conheci Dom Lorenzo, em 2008, ele ficava vários dias na cidade e o seu rebanho nas serras. Era pleno inverno, mas Dom Lorenzo afirmou, várias vezes, que não havia problema em ter os animais sozinhos nas serras, pois ele os havia deixado numa pampa de altura onde tinham pastagem e água. Se acaso acontecesse alguma coisa, algum vizinho o ajudaria.

É comum aos pastores, deixarem os animais em algum lugar e se ausentarem por alguns dias. Logo voltam e remanejam esses animais para outra área. Outro movimento comum neste período de inverno é a ida até locais com água, que não são muito abundantes. Os pastores deixam o seu rebanho pastando e logo os levam até olhos d'água não perenes e logo retornam com o rebanho para as pastagens.

Durante o inverno e no começo da primavera, os pastores e os rebanhos estão em constante movimento, alcançando cada vez altitudes mais elevadas em busca das águas não perenes e dos pastos resistentes ao frio. Por isso, é comum ver as pampas de altura povoadas de animais pastando, assim como ver os currais do alto das serras sendo utilizados para o descanso. Apesar de que os pastores fazem trajetos mais longos neste período, eles não se ausentam da casa residencial por muito tempo. 
Numa conversa que tive com Dona Maria, ela me contava que Dom Vicêncio, assim como o seu pai e o avô, não se ausentavam durante períodos longos da casa. Dona Maria afirma que, deste lado da serra do Cajón onde eles moram, não é habitual essa prática, tanto que ela esperava Dom Vicêncio até tarde da noite acordada, se fosse necessário.

É importante ressaltar isto, as obrigações do pastor não se restringem apenas ao rebanho e, ao se ausentar por um tempo prolongado, outras áreas ficam sem cuidados. Dom Vicêncio diz que, quando habitavam a casa no interior das serras, não poderia se ausentar por muito tempo, pois a horta e as árvores frutíferas poderiam morrer sem os cuidados necessários. Dona Maria conta que algumas árvores frutíferas (como pessegueiros e um pé de marmelo) são importantes para fazer os doces e as compotas no verão. De acordo com o que conta Dona Maria, essas árvores foram plantadas por sua bisavó, e diz que sempre deram muitos frutos, que as compotas do verão rendiam um complemento em produtos de troca e em dinheiro para fazer outras compras, também sobrava uma boa quantidade para a família passar o inverno.

A mobilidade pastoril deste lado da serra do Cajón restringe-se a uma mobilidade logística, considerando-se que o pastor deve dividir o seu tempo em períodos com o rebanho - em busca de boas pastagens e locais com água - e as atividades suplementares que levam a cabo. A relação entre as duas partes deve ser harmoniosa em questão de necessidades, assim conseguem prosperar.

No gráfico a seguir é possível observar a flutuação aproximada dos movimentos pastoris em esta zona da serra do Cajón. Como foi colocado, a mobilidade pastoril desta zona corresponde principalmente a movimentos logísticos, nos quais o pastor se desloca com o rebanho para acessar os recursos, assim, movimenta-se mais na estação de estiagem que na estação chuvosa. 


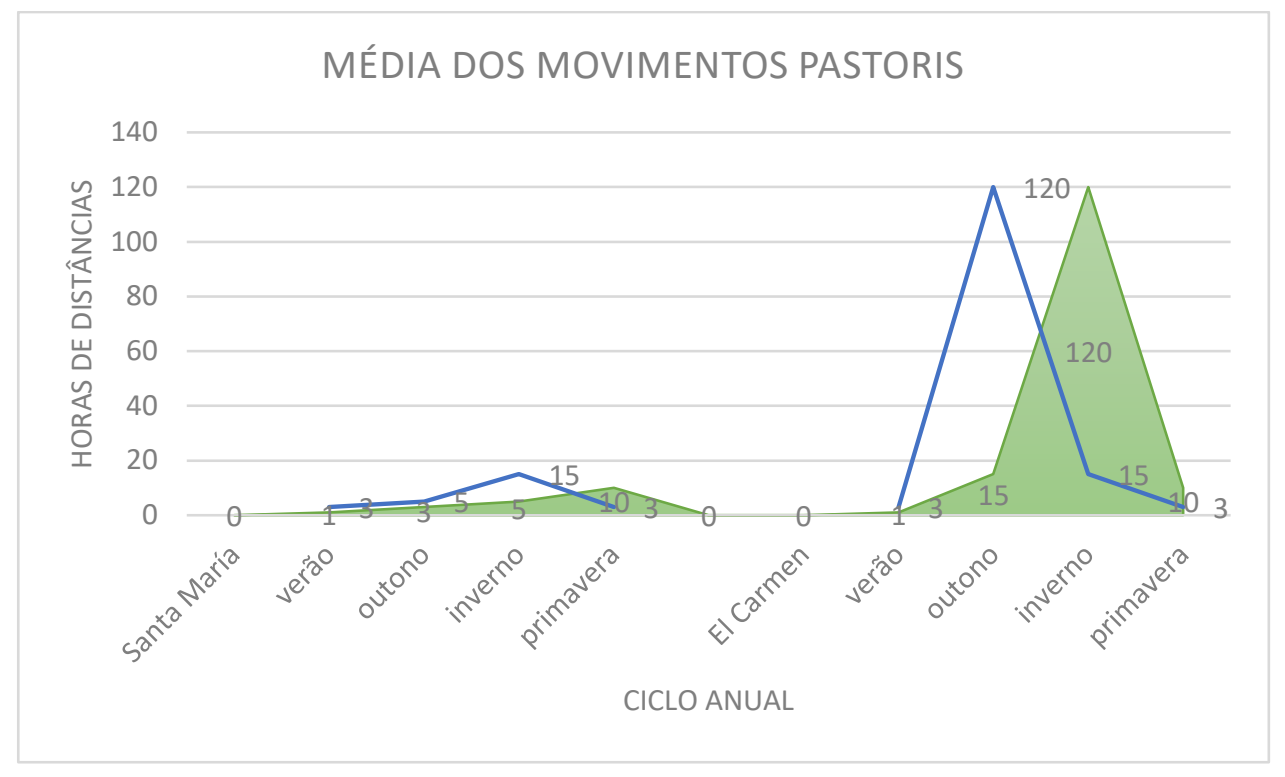

Figura 19. Gráfico representando as médias de movimentos pastoris referentes a Santa Maria e El Carmen. Faz-se uma relação entre as horas caminhadas (ida e volta) e as estações do ano.

\subsection{5 - Distâncias longas}

Estes movimentos consistem na formação de grandes caravanas que se deslocam por longas distâncias para levar os rebanhos a serem vendidos no mercado regional. O movimento pode durar longos dias de viagem de ida e volta. Durante estas viagens, os pastores vão anotando pedidos e distribuindo produtos, ao longo de todo o caminho.

Dom Vicêncio conta que, uma vez ao ano, faziam todos os caminhos pelas montanhas, seguindo os passos entre montanhas e quebradas para levar os animais a San Pedro. Levavam e trocavam produtos durante o caminho e voltavam com vários produtos.

- No caminho nos encontrávamos com outros e assim seguíamos. Nessa época, tudo era trueque ${ }^{20}$. Levávamos as coisas e as trocávamos pelo que podíamos e por aquilo de que necessitávamos.

Assim, Dom Vicêncio, seu pai e irmão, com mais outros pastores do lugar, saíam de sua localidade e seguiam os caminhos para outros centros, "iam seguindo e parando nos lugares, trocando farinha, açúcar e coisas assim..." conta este senhor.

\footnotetext{
${ }^{20}$ Trueque, é a palavra que usam para se referirem às trocas.
} 
As caravanas podiam durar vários dias, nos quais os pastores, junto aos animais do rebanho (para carga e para venda), faziam longos trajetos pelas serras até chegar ao local onde se fazia a troca do mercado regional. Neste período, o pastor ausentava-se de casa durante um tempo prolongado, correspondendo às maiores distâncias percorridas.

O hábito das caravanas ainda existe. Dom Yucra, que vive em El Carmem, afirma que, uma ou duas vezes ao ano, as caravanas sempre passam por perto. Ele diz que não passam especificamente no caminho de sua casa, mas que ele sabe mais ou menos a época e fica atento às informações dos vizinhos (que vão fazendo uma rede de avisos, conforme as caravanas vão passando e se aproximando) e então, Dom Yucra aproxima-se dos caminhos pelos quais eles passam.

Dom Yucra e Dom Vicêncio já não participam mais das caravanas por causa da idade, porém continuam entusiasmados com as lembranças dos trajetos. Hoje em dia, estes pastores vendem os seus animais para outros que os levam até os mercados regionais, ou então os vendem em troca de produtos com os vizinhos.

\subsection{6 - Troca de produtos e as caravanas}

A troca de produtos locais também é muito comum. Faz-se por meio de uma rede de relações e trocas que extrapolam a simples venda direta. Nem sempre um produto é trocado por outro, muitas vezes se estabelece uma relação de trocas que pode ser muito mais longa em tempo. Assim, um produto pode ser trocado por outro, mas outras vezes, alguns produtos são trocados, esperando-se receber de volta outros produtos, em outro momento.

Por exemplo, uma tarde na casa de Dona Maria e Dom Vicência, chega a moça que distribui o pão na localidade. Ela leva uma grande cesta com pão (que ela mesma faz) e vai distribuindo pelas casas. Quando a vê chegar, Dom Vicêncio faz um sinal, levantando a cabeça com os olhos franzidos em interrogação, para Dona Maria, e ela lhe diz que desta vez tem de pagar. Enquanto Dom Vicêncio paga o pão à moça, Dona Maria explica que ela queria comprar alguns animais, por isso montou uma espécie de padaria ali e estava fornecendo o pão, para poder comprá-los.

Observando essa situação da moça que deseja comprar animais para a família pastorear, Dona Maria diz que, hoje em dia, as coisas ficaram um pouco mais 
complicadas por um lado e mais simples por outro. Ela diz que hoje é possível pedir um taxi na cidade para receber alguns produtos, mas que ela sente falta de algumas coisas que só conseguia com os vizinhos.

Ainda existem algumas famílias que têm por hábito essas trocas entre produtos, principalmente produtos da estação. Nesta região, as nogueiras que as pessoas têm em suas casas dão muitos frutos, porém estas nozes são pequenas e não têm valor comercial, assim, na época de nozes, as pessoas juntam grandes quantidades para levar a seus vizinhos que retribuem com outros produtos em troca.

Este relato de Dom Vicêncio evidencia uma das características fundamentais do sistema pastoril do Vale de Santa María e dos Andes em geral. A existência de caravanas permitiu que até os grupos mais isolados tivessem acesso a determinados produtos, além de possibilitar a venda de animais em todos os níveis, vinculando todos os pastores a uma rede de mercados locais e regionais.

\section{2 - A motivação dos movimentos}

As características gerais do movimento dos pastores no vale de Santa María apresentam uma semelhança que pode ser comparada com a migração de alguns tipos de camelídeos característicos da zona.

Quanto à migração animal, é possível compreendê-la como uma adaptação, uma interação entre a genética particular do animal e o ambiente. A migração animal, geralmente, envolve uma resposta às variações espaço-temporais nos recursos, portanto, movimentar-se permite explorar diferentes nichos ecológicos para sobreviver (Creswell et al 2011; Cresswell e Quinn 2011).

No ambiente andino, a vegetação cresce em uma sucessão de altitudes, assim, a migração animal relaciona duas questões: "onde ir?" e "quando ir?" . Na primeira, lidase com orientação e navegação, de acordo à abundância de pastagens e água favorável (para o crescimento e a reprodução) e, na segunda, lida-se com tempos e atividade e ordem migratória, que facilitam a sobrevivência em períodos de clima extremo (Jonzén et al 2011; Behnke et al 2011).

Desta forma, em ambientes montanhosos é comum a presença de animais migratórios, que mudam de áreas de acordo com o tempo e as precipitações. Uma 
constante é o crescimento da vegetação, primeiro nas áreas menos elevadas. Isto também acontece com as áreas andinas, a diferença é que o vale de Santa María, apresenta um clima que vai do árido ao semiárido e, em áreas mais elevadas, conta com uma vegetação adaptada que persiste nas temporadas mais frias do ano (como já foi especificado no Capítulo 1). Por sua vez, as lhamas tendem a permanecer nos meses chuvosos próximo aos vales e, com a diminuição das chuvas e o avanço do inverno, os animais vão para as áreas mais elevadas em busca das pastagens mais resistentes. Tradicionalmente, os pastores deslocam-se de acordo com a oferta de pastagens para os animais, permanecendo nas áreas dos vales nos períodos de verão (chuvoso) e alcançando as áreas mais elevadas para alimentar os seus rebanhos nos períodos de inverno. Ainda hoje, com a presença mais massiva de cabras nos rebanhos, estas rotas continuam sendo muito parecidas com as rotas de migração que os camelídeos -como as lhamas - apresentaram em outros momentos.

Correlações espaciais e flutuações no tempo dos recursos podem estar impulsionando a decisão dos movimentos, tanto o pastoril quanto o da migração animal. Ambas dimensões - temporal e espacial - implicam na pressão seletiva que leva ao movimento, pois estas dimensões estão relacionadas à paisagem e representam efeitos indiscutíveis no movimento humano, embora, apesar das semelhanças, o movimento pastoril não seja igual à migração animal.

Além da busca por pastagens e água, as sociedades pastoris gerenciam uma série de regras e instituições que organizam os processos humanos de comportamento, bem como, o acesso aos recursos e o gerenciamento de possíveis conflitos. Existe uma relação muito próxima entre: instituições, padrões de movimento, e a tendência biológica dos animais ao movimento e distribuição pelo ambiente. Há similaridade entre os rebanhos pastoris e os ungulados selvagens, apesar de que, à simples vista, podem parecer muito próximos. Os padrões pastoris respondem a uma ordem mais ampla que unicamente as questões ambientais. Por isso é tão difícil generalizar a organização do sistema de movimentos de um grupo pastoril, pois o movimento representa os hábitos do rebanho, subordinado às variações de objetivos culturais, sociais e econômicos (Behnke et al 2011).

O pastoreio nômade é uma especialização que preenche nichos ecológicos e econômicos, tirando vantagem da sazonalidade da vegetação e dos ciclos regulares de migração. Em determinados lugares, o pastoreio móvel é mais sustentável que a 
agricultura. Por isso, os grupos pastoris podem se distinguir pelas razões pelas quais pastoreiam os seus animais. Como já foi colocado no capítulo anterior, os pastores têm em comum o interesse pelo rebanho, porém diferem no uso das diferentes estratégias alinhadas aos seus objetivos. Destas estratégias é possível destacar cinco tipos, que representam reduções analíticas possíveis:

1-) Pastores nômades- são aqueles que se deslocam junto a todo o grupo familiar. Não apresentam distinções de movimento (número de movimento e mais tempo de estadia) entre temporadas secas ou chuvosas.

2-) Pastores transumantes- são aqueles que apresentam movimentos sazonais. Movem-se com parte da família e apresentam um padrão de movimento bem definido em questão de estações secas e chuvosas.

3-) Agropastoris- representados como famílias assentadas com pastores nômades, as famílias vivem permanentemente perto dos centros (mercado, escola, cidade etc.) enquanto o pastor se movimenta. Apresentam a sua própria terra e cultivos, destacandose apenas um local permanente integrado a uma rede ou apenas outro local temporário.

4-) Fazendeiros sedentários pastores- apresentam um assentamento permanente, e pastoreiam os animais em locais próximos às próprias propriedades, sem se deslocar.

5-) Ferced ranchers- é um tipo especial de pastoreio, onde os animais ficam restritos a uma área delimitada por cercados. Estes cercados funcionam para deixar os animais longe dos plantios agrícolas. Este tipo pode apresentar assentamento permanente, nem sempre junto ao rebanho.

De acordo com o que foi colocado no capítulo 2, com relação à produção do rebanho, estes pastores no vale de Santa María estariam definidos como "pastores nômades e agropastoris", o que abre um grande leque de definições em questão de mobilidade. Isto porque, vale lembrar, as terminologias são abreviações e ao mesmo tempo generalizações de sociedade particulares com movimentos específicos (Wendrich e Barnard: 2008: 8). Por isso, apesar de se fazer estas reduções, com intuito meramente analítico, não se deixa de considerar os comportamentos e adaptações e a existência singular humana em constante fluxo.

Desta forma, o sistema de produção pastoril no vale de Santa María poderia ser incluído no item 3 como agropastoris combinado com o sistema de mobilidade destacado 
pela transumância do item 2. Isto porque, para compreender o sistema pastoril com o qual se está trabalhando, é fundamental compreender as estratégias adaptativas tradicionais do sistema, juntamente com as especificidades da geografia e das condições climáticas.

Como destacou-se no capítulo 2, o modo de produção destas populações pastoras integra uma atividade agrícola ao pastoreio tradicional. No que se refere aos plantios, os relatos apontavam para a escolha de produtos de subsistência, na sua maioria, aliados a uma atividade complementar como a presença de frutas para consumo e para a venda dos subprodutos. Essas atividades estão destacadas no quadro a seguir, subdivididas entre três famílias:

\section{Família de Dom Vicêncio}

- Produção: agrícola de susbsistência, pastoreio;

- Tipos de trocas: de produtos entre vizinhos, caravanas, aquisição de produtos de mercado;

- Tipos de venda: venda dos produtos e subprodutos do pastoreio;

- Acesso: caravanas, a escola e ao centro urbano (menor medida).

\section{Tipo de produção}

\section{Família de Dona Maria}

- Produção: agrícola de subsistência, produção de frutas, pastoreio;

- Tipos de trocas: de produtos entre vizinhos, caravanas aquisição de produtos de mercado;

- Tipos de venda: de subprodutos frutais, de produtos e subprodutos do pastoreio;

- Acesso: caravanas, a escola e ao centro urbano (em menor medida).

\section{Família de Dom Vicência o Dona María}

- Produção: agrícola de subsistência, pastoreio, trabalho assalariado;

- Tipos de trocas: de produtos entre vizinhos, caravanas, nos mercados;

- Tipos de venda: de produtos e subprodutos do pastoreio;

- Acesso: caravanas, a escola e aos centros urbanos (em maior medida).

Tabela 09 - Tipos de produção divididos por famílias.

Esta região do vale de Santa María, tradicionalmente, indica um histórico de uso da terra e de seus recursos, a partir da combinação entre cultivos de cereais, vegetais adaptados, frutas e nozes, e pastoreio transumantes. A aridez e à dificuldade de irrigação 
fizeram que estes vales não fossem favoráveis à agricultura em larga escala. As condições geográficas e climáticas também fazem com que os vales sejam aptos para o pastoreio apenas por um período do ano (correspondendo aos períodos finais da primavera e verão), isto obriga os pastores a apresentar movimentos distintos de acordo às épocas do ano. Esta estrutura de movimentos de acordo às mudanças climáticas e oferta de água e outros recursos naturais também foram destacados para outras zonas andinas, destacando a importância desta mobilidade pastoril, aliada à economia vertical tipicamente andina, diante da qual se definiu um padrão compreendido como transumância vertical (Browman 1983).

\subsection{1 - Definição de transumância. Sobre qual sistema de mobilidade estamos falando?}

A possibilidade de plantio e o movimento pastoril correspondem às condições ambientais que se mostram mais favoráveis. Nos meses mais chuvosos, a proximidade do pastor da residência fixa - nas proximidades dos vales - permite uma integração entre um sistema agrícola (ainda que pequeno) e um sistema de pastoreio. Os animais herbívoros que constituem o rebanho são centrais para a economia e sobrevivência destes grupos, porque estes animais conseguem digerir plantas com alto nível de celulose, transformando vegetação de baixa qualidade em produtos de alta qualidade. O resultado são produtos com valor nutricional alto, como a carne (produto direto) e a venda dos animais e seus subprodutos (produtos indiretos conseguidos por meio de trocas e venda/compra).

O problema é que estes pastores tradicionais alimentam os seus rebanhos com pastagens naturais não preparadas, portanto, diante das adversidades climáticas das diferentes estações do ciclo anual, os pastores são obrigados a movimentarem-se no interior das serras para alcançar pastos que não secam nem perecem nos períodos mais frios do ano. Portanto, por definição, lida-se com um sistema agropastoril transumante, aliado às características que levam a defini-lo como um sistema combinado de atividade agrícola moderada e pastoreio tradicional.

Sobre o termo transumância, existe uma série de definições destacadas na literatura pastoril. Existem diferenças quanto à mobilidade de cada grupo pastoril, de acordo com as distâncias totais que percorrem no total de um ciclo anual e as 
características do movimento (ver Sidky 2015). A transumância é o termo utilizado para definir aqueles movimentos pastoris caracterizados por:

1-) Movimentos limitados em escala-geralmente têm lugar em um único sistema de vale, os movimentos ocorrem de maneira vertical, em relação aos vales e às partes mais elevadas.

2-) Movimentos distintos entre os integrantes de um grupo- uma parte do grupo permanece assentada durante o total do ciclo anual, enquanto uma parcela pequena do grupo se movimenta com o rebanho.

3-) Existência de acampamentos diferenciados- mantêm um local permanentemente ocupado integrado a uma rede de acampamentos temporários.

Assim, o pastoreio transumante pode ser definido pelo movimento vertical, o qual compreende grupos que se movimentam através de distintas altitudes, como é o caso dos pastores do vale de Santa María. Também apresenta uma distinção entre movimentos sazonais - o movimento de inverno e o movimento de verão -, que são fundamentalmente característicos de todos os tipos de pastores nômades, pois todos os nômades fazem uma distinção entre os locais mais vantajosos para manter os seus rebanhos de acordo com a sazonalidade, condições climáticas e geografia. 


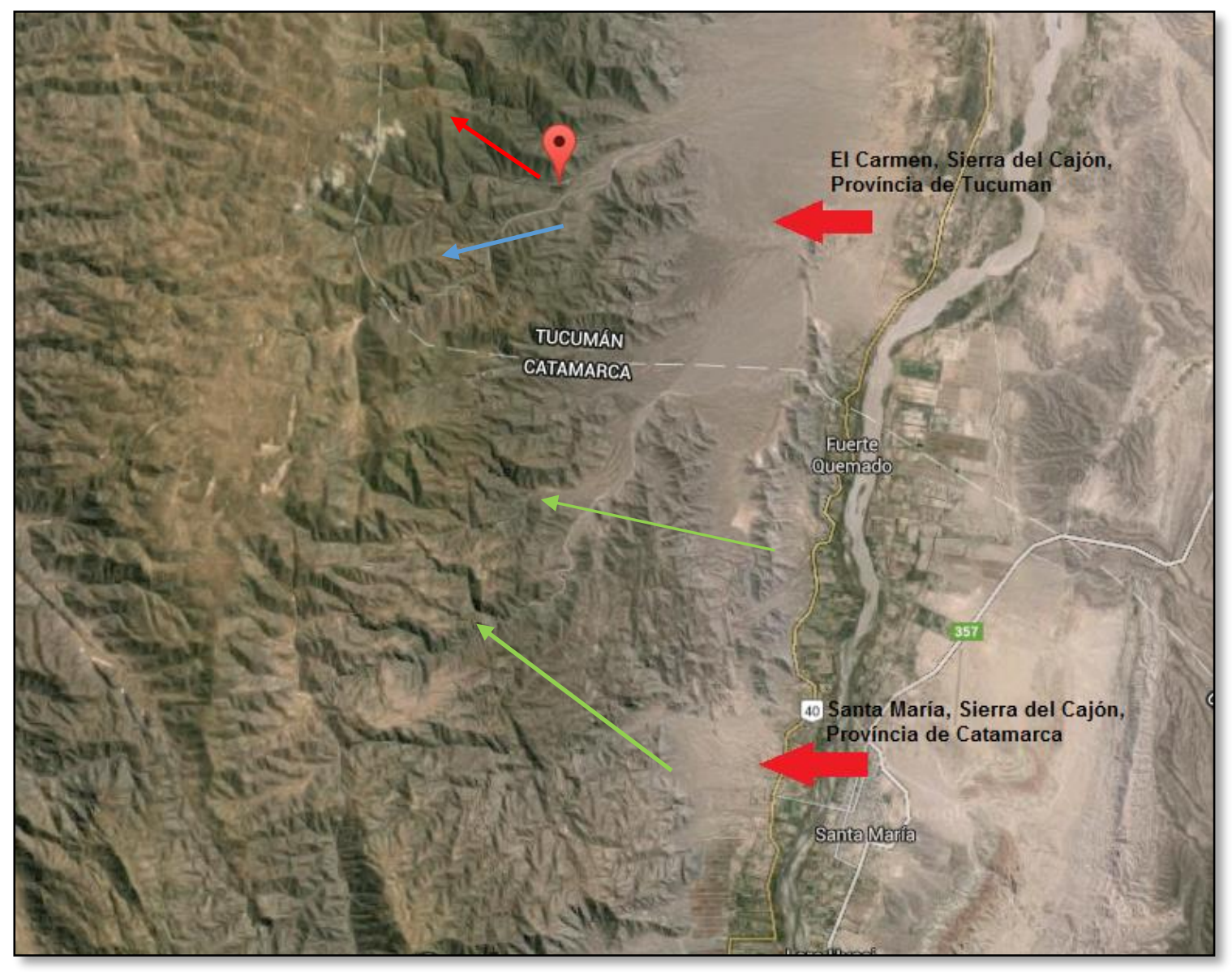

Figura 20 - Imagem indicado mapa de Santa María com as direções aproximadas que os pastores seguem.

Este mapa indica o movimento geral dos pastores no vale de Santa María. Os movimentos indicados pelas flechas são representações das informações colhidas em campo. Ainda não foi possível recriar fielmente os movimentos observados. Porém, é possível identificar que os pastores estão se movimentando do vale em direção ao interior das serras, fazendo trajetos em áreas ainda próximas aos vales, durantes os períodos de outono e movimentos mais longos, em busca das pastagens resistentes ao frio, no período referente ao inverno. Considerando as informações colhidas, foi possível identificar, de forma geral, os movimentos transumantes dos pastores no vale de Santa María.

\subsection{2 - Características gerais do movimento no vale de Santa María}

Seguindo as características apresentadas, destaca-se o tipo de mobilidade característica dos pastores do vale de Santa María respondendo a uma ordem vertical, 
porque se movimentam dos vales até o interior das serras, percorrendo altitudes diferentes neste processo. O padrão de mobilidade varia entre as estações de inverno e verão, sendo que, no período do verão, o grupo está assentado na casa junto à família. O movimento dos pastores está constituído de três fases fundamentais.

As cabras são o foco do ciclo de transumância entre os interlocutores desta tese. É característico a estes pastores os animais serem deixados para pastarem durante um tempo determinado sem a presença do pastor para organizar o rebanho. Esta prática, aliada à capacidade das cabras de se autoguiarem, permite ao pastor um certo grau de autonomia em relação ao seu rebanho. As cabras alimentam-se de uma gama de vegetação que não sustentaria ovelhas ou vacas. São capazes de comer arbustos e folhagens que crescem nos precipícios. Uma cabra adulta consome aproximadamente $2 \mathrm{~kg}$ DM por dia. Também são animais que se reproduzem sazonalmente e atingem a vida adulta com 30 meses. A gestação dura em torno de cinco meses, tendo lugar no fim do inverno e começo da primavera. As cabras dão crias de um ou dois bebês. Durante o período de lactação, uma cabra pode produzir aproximadamente 300 litros de leite (o dobro do leite produzido pelas vacas) (Sidky: 2015: Pos 2332-48, 29\% DOI). Portanto, o rebanho de cabras é indicado como vantajoso na prevenção de riscos de perda de animais pela dificuldade de pastagens e/ou água. As cabras indicam ser animais extremamente vantajosos para áreas de montanhas e ambientes extremos como o do vale de Santa María.

Os rebanhos são de propriedade de cada pastor. Também existem propriedades de terras, porém os locais de pastagens e locais de água não são restritos. As pastagens abertas ou áreas comunitárias são comuns a populações pastoras no mundo todo, segundo a ideia de que locais de água e pastagens são acessíveis a todos (Abusuwar e Yahia 2010). Estas estratégias integradas permitem ao pastor uma dupla atividade, podendo estar no comando de um rebanho e exercer outras atividades para a sua própria família ou para outros na forma de trabalho assalariado.

As espécies mais nutritivas de plantas e gramíneas crescem no período do verão, com o aumento das chuvas na região. Esta vegetação é características das altitudes mais baixas dos vales ou nas proximidades. A chuvas ocorrem em um período que compreende os meses de novembro a março (aproximadamente). Neste período, com os vales férteis e com abundância de água, os animais podem pastar soltos dentro do perímetro referente à casa, sem a necessidade de cuidados. Os pastores ficam mais tempo na casa principal junto às mulheres e às crianças. 
As pastagens são produtivas unicamente nesses períodos de maior umidade, portanto, conforme cessam as chuvas, os vales vão secando e a vegetação vai diminuindo. Neste momento, o pastor já tem necessidade de se movimentar com o rebanho, buscando por áreas que ainda estejam férteis, porém, na maioria das vezes, faz trajetos curtos. Esta é uma fase intermediária entre o outono e o inverno, porém, apesar da diminuição, ainda existem pastagens relativamente próximas. Os animais, muitas vezes, retornam aos currais principais.

Com o avanço do inverno, as pastagens ficam mais escassas e os pastores fazem uso de locais de pastagens e de água no interior da serra, aproveitando o tipo de vegetação mais resistente ao frio e a falta de água que cresce nas zonas mais altas. Durante estes períodos, os rios dos vales em menor altitude secam pelo fim do degelo, a incidência de chuvas é escassa e neva em grandes quantidades cobrindo os campos e congelando as áreas de água.

Por causa destas limitações climáticas, os pastores são obrigados a movimentarem-se em busca de lugares com água e pastagens para os animais. Com isto, eles percorrem longas distâncias e utilizam vários locais de paragem, os postos temporários (na maioria das vezes, por apenas uma noite), durante a rota de pastoreio, até a volta das chuvas e do clima mais ameno quando voltarão à casa de campo. No geral, os animais permanecem no interior das serras, porém os pastores se deslocam da casa até os animais. Atualmente, poucos pastores ainda permanecem no interior das serras próximos aos animais Estes relatos centraram-se mais no vale de El Carmen, destacado como um vale (dentro do vale de Santa María) que está localizado um pouco mais distante do centro urbano de Santa María.

Neste período, o uso das pastagens e dos locais de água não perene deve apresentar uma regulamentação. Entre os relatos colhidos sobre o assunto, os pastores indicavam que não levariam os seus rebanhos a áreas onde já existisse o rebanho de um vizinho, ou se isso acontecesse, eles se certificariam de que eram locais que suportavam ambos os rebanhos.

O ciclo de transumância anual começa no final de abril e começo de maio e termina entre os meses de outubro e novembro, com a volta das chuvas. É baseado na observação da maturação das pastagens, na queda da incidência das chuvas, na diminuição das temperaturas e nos períodos de glaciação. Este calendário tem a função 
de gerenciamento dos recursos que resguardam as pastagens mais resistentes para os períodos que as necessitam. Juntamente com o controle das pastagens, também há uma regulação da quantidade de animais adultos no rebanho. Este controle ocorre pelo abate e/ou venda de animais. Lembrando que a nora de Dona Maria estava muito preocupada porque estava ficando muito apegada aos animais e, com isso, ficava apenada de abater os animais.

Neste ambiente do vale de Santa María, o rebanho não conseguiria sustentar-se sem a mobilidade, porém usar as diferentes áreas desse ecossistema frágil não necessariamente significa degradar o ambiente. Alguns autores defendem a ideia de mecanismos de preservação e regeneração do ambiente, uma vez que o pastoreio é flexível e seletivo e os rebanhos não pastam sem controle, mas em locais selecionados e avaliados. Os pastores tendem a dispersar-se e fazer uso mais extensivo de locais de água e pastagens nas épocas chuvosas e preservar certas pastagens nas - ou, para as - épocas mais secas do ano (Sidky 2015; Abusuwar e Yahia 2010; Mortiz et al 2014).

A hipótese é a de que há um sistema de gerenciamento e auto-organização que pode ser previsto, pensando em uma distribuição ideal livre (IFD-Ideal Free Distribution) dos pastores móveis nas áreas naturais de pastagens. O conceito de IFD tem sido utilizado pela ecologia comportamental para examinar as estratégias dos animais. Apenas recentemente começou-se a aplicar este estudo para compreender a mobilidade e o padrão de assentamento das populações humanas. Como o pastoreio não é livre, mas regido por determinadas leis - mesmo que já tenham sido naturalizadas ao ponto de integrar o senso comum -, é possível considerar que a transumância anual estaria pautada por preferências habituais que podem (ou devem) influenciar as decisões de movimento, mesmo quando o tempo de viagem entre os locais de água e pastagem não é elegível (Moritz et al 2014).

Considerando-se que há um senso comum na regulamentação ao acesso aos recursos, seriam essas decisões que o pastor individual consideraria para coordenar os movimentos de acordo com o ambiente, as mudanças na distribuição dos recursos, e ainda considerando a distribuição dos vários pastores. Isto permite concluir que existe um certo equilíbrio entre a tomada de decisão para o movimento e a capacidade das pastagens em relação ao número de animais (carrying capacity), confirmando uma escolha de um padrão de movimento pastoril acertada. 
Assim, como vários outros grupos de pastores em áreas montanhosas (ver Sidky 2015), os pastores do vale de Santa María movem os seus rebanhos por rotas claramente definidas através das sucessivas altitudes, para obter o máximo de aproveitamento dos diferentes nichos que sustentam o rebanho e, consequentemente, dos humanos, sem interferir no ecossistema frágil das zonas Andinas.

O gráfico a seguir indica as altitudes que os pastores atingem de acordo com a estação do ano em questão. O gráfico foi montado com movimentos aproximados para mostrar que conforme avança o inverno, os pastores atingem as maiores altitudes.

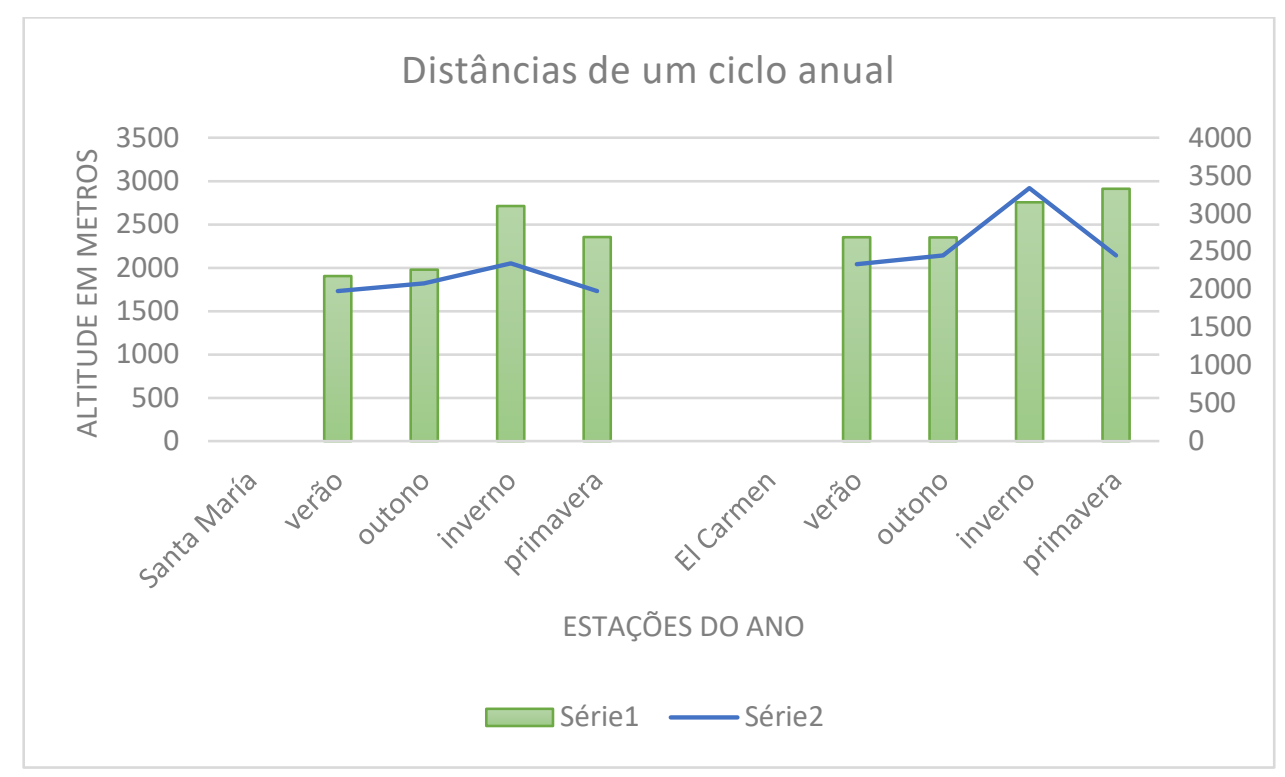

Figura 21 - Gráfico de mobilidade pastoril. Representa as distâncias relativas, entre as altitudes alcançadas de acordo às estações do ano.

Este modelo de mobilidade que ocorre nos vales, durante o verão e, no interior das serras, durante o inverno, parece estar presente nestas serras há vários anos. Porém, ao que parece, mudanças nas categorias podem ser identificadas ao longo desses anos. Sanz Arechaga (1948) destaca a presença de dois tipos assentamento que se mantinham fixos. A casa residencial seria a morada do pastor, onde permaneceria assentada a sua família quando este estivesse no interior das serras com o rebanho. Durante o movimento dos meses de inverno, os pastores visitariam postos temporários fixos no interior da montanha, distribuídos em territórios estreitos, porém longos em extensão (distribuídos verticalmente desde o vale até os altos picos). Aqueles pastores que não apresentavam 
territórios eram obrigados a se movimentarem diretamente às zonas mais altas que não eram propriedade particular de ninguém. Porém, os dados etnográficos atuais mostram um sistema um pouco diferente desse descrito pela autora em meados do século XX.

Atualmente, os pastores não permanecem mais no interior das serras assentados, eles se movimentam até os locais de água e pastagens com os seus rebanhos e deixam os animais soltos por alguns dias retornando à residência principal. $\mathrm{O}$ fato do pastor não permanecer no interior das serras junto ao seu rebanho, mas movimentar-se, indo ao encontro deste, não modifica muito a estrutura principal do movimento. Os rebanhos estão percorrendo a rede de locais com pastos que persistem ao inverno, fazendo que o pastor alcance esses lugares, indiferentemente, do seu retorno à residência ou não. Por sua vez, a existência de postos temporários persiste, ainda quando tenham mudado de função.

O pastoreio implica a busca constante por pastagens e fontes de água, assim o pastor e o seu rebanho são forçados a se moverem de um lugar a outro várias vezes ao ano. Em virtude desse modo de vida transumante, toda a sua estrutura de organização, bem como a sua produção e necessidades materiais, estão adaptadas aos movimentos frequentes, à ordem de distribuição e a quem se movimenta e a quem não se movimenta.

O processo da mobilidade, por sua vez, influencia todas as outras instâncias da vida cotidiana. Assim como os pastores apresentam essa preferência pelo gado, movimentar-se implica vida. Portanto, habitar também é um processo do movimento e de perceber o tempo e os lugares. Os tipos de assentamento estão intrinsecamente ligados à necessidade para cada período do movimento, apresentando uma funcionalidade em relação aos seres humanos e aos animais que ocupam o espaço, podendo funcionar de maneira complementar, quando a possibilidade de um implica diretamente a necessidade do outro.

\section{3 - Tipos de Assentamento}

A cidade de Santa María é uma cidade antiga. Seu centro urbano, no estilo tradicional das cidades de influência espanhola, estrutura-se ao redor da praça. Percorrendo a cidade, observa-se a mistura de épocas e estilos, característicos dessas cidades que persistiram ao longo dos anos. Santa María cresceu bastante nos últimos anos. 
É possível encontrar casas modernas e construções atuais ao lado de antigas casas coloniais. A área urbana, na sua maioria, está localizada à direita do rio Santa María e o seu crescimento ocorre ao longo do rio em sentido norte/sul do que cruzando.

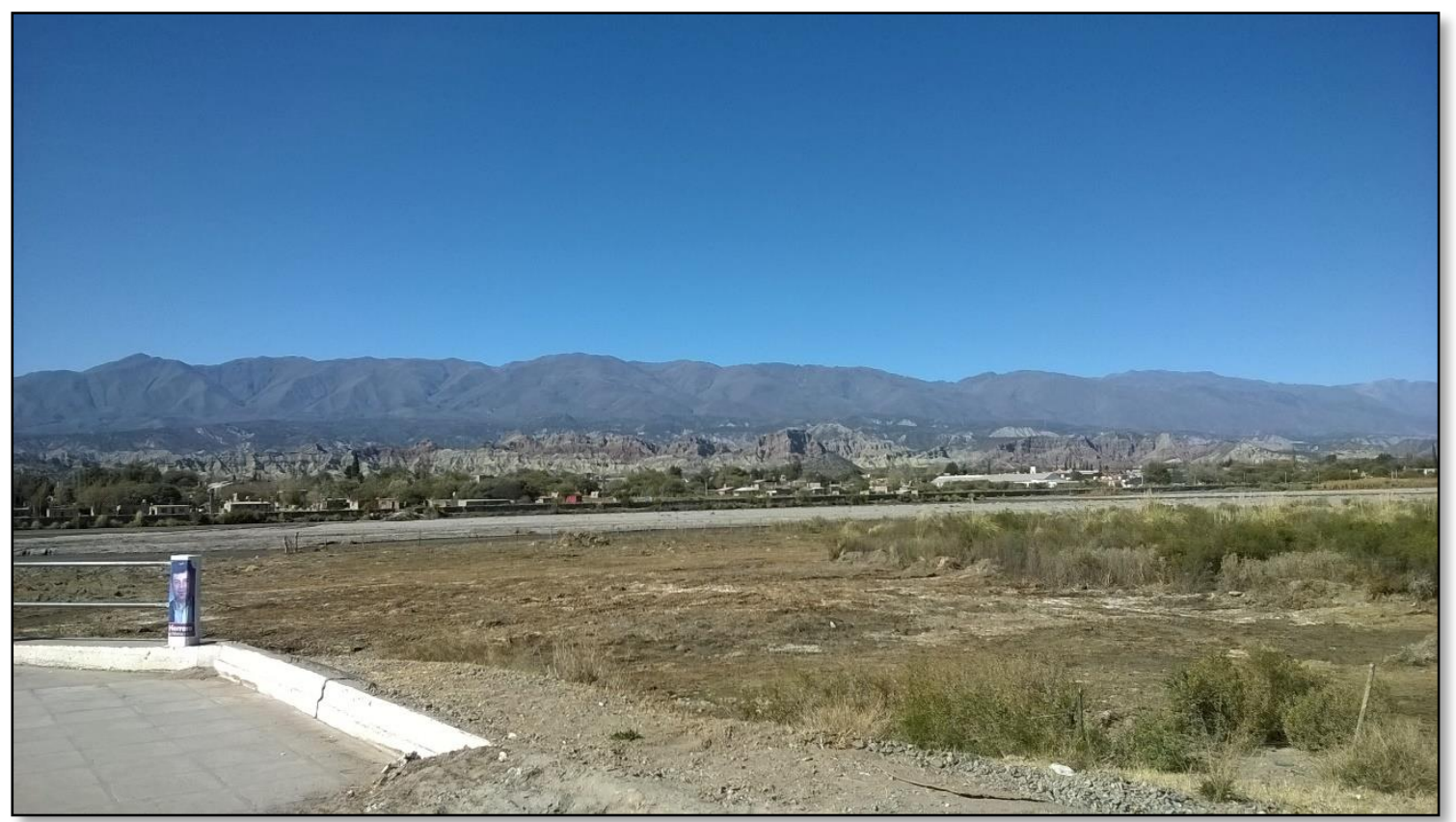

Figura 22 - Foto da cidade de Santa María. Vista do outro lado do rio Santa María.

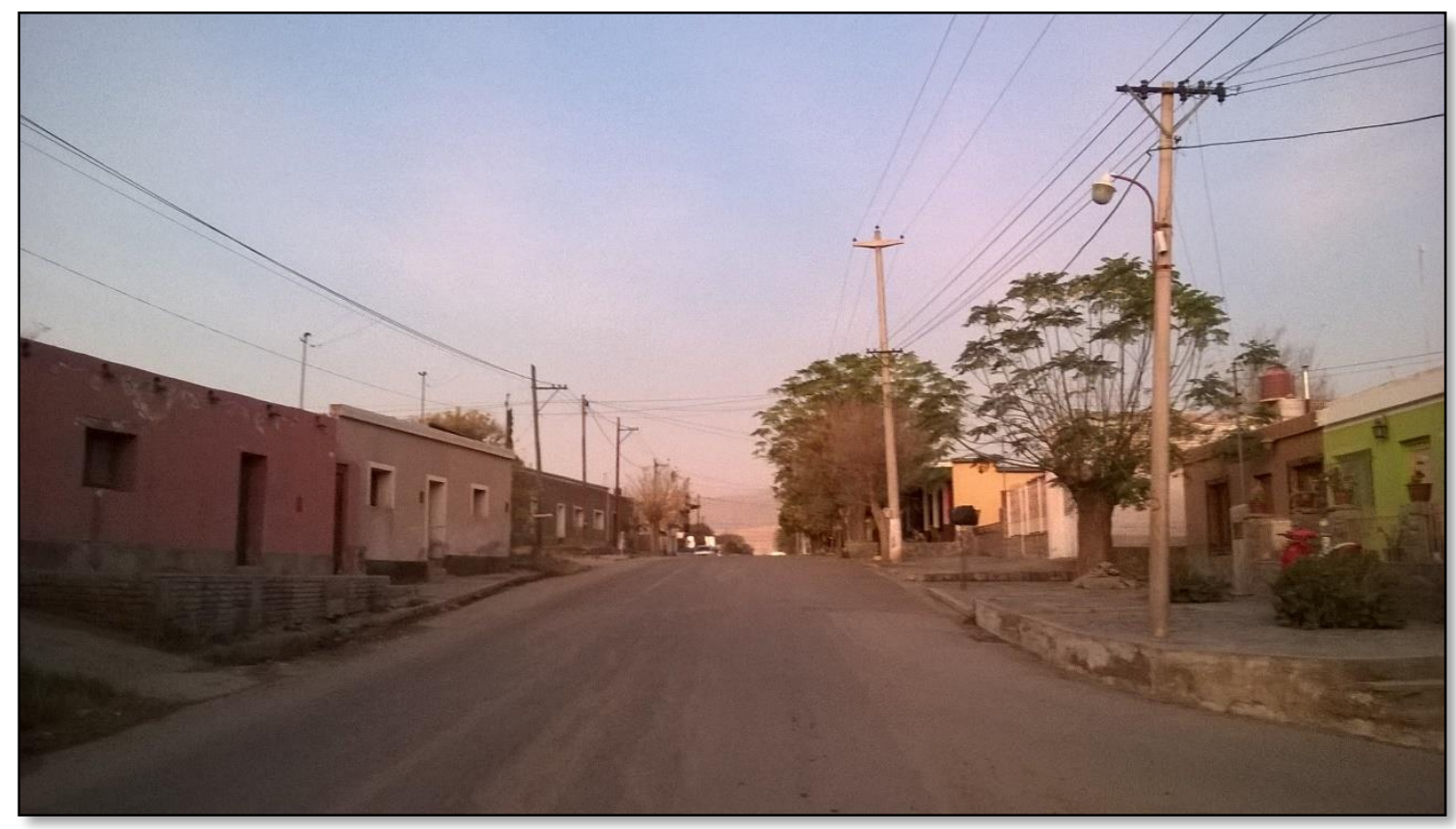

Figura 23 - Foto da cidade de Santa María. Algumas casas antigas frente a frente com casas mais modernas, na cidade de Santa María. 
Do outro lado do rio, existem alguns bairros, como o que mora Dom Vicêncio. Estes bairros estão ao pé da serra do Cajón.

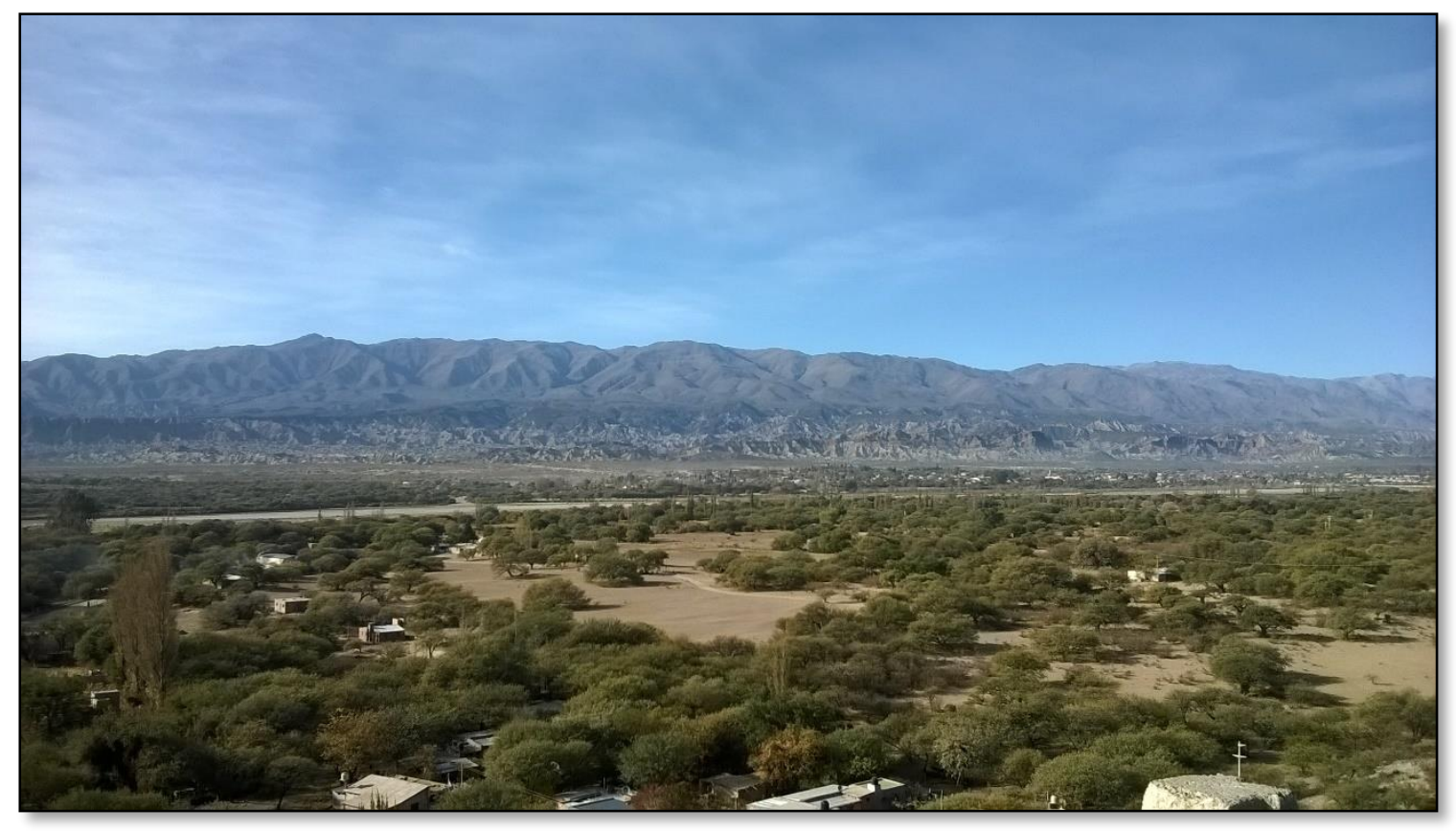

Figura 24 - Foto da vista de Las Mojarras. Indicando a presença do rio Santa María e da área urbana da cidade de Santa María, ao fundo.

Nas áreas mais próximas às serras o tipo de construção muda. Observam-se casas com um estilo, ainda que próximo ao colonial, porém representado pela vida nas serras, com guardas de lascas de pedra, janelas pequenas, cozinhas nas áreas externas etc.

Especificamente, quanto aos pastores, os tipos de assentamentos que lhe são mais característicos dividem-se em três categorias, diferenciadas pelo número de pessoas, uso, local e período de permanência. A arquitetura depende dos materiais disponíveis e das atividades que vão ser levadas a cabo em cada local.

\section{1 - Casas na cidade}

O primeiro tipo de assentamento que detectei são as casas de cidade, localizadas na área do vale próximas ao centro urbano da cidade de Santa María. Estas casas estão localizadas ao pé da serra do Cajon, na margem do rio oposta ao centro urbano da cidade. 
Estas casas integram o estilo moderno de construção, feitas com tijolos, rejunte, telhados de telha, janelas e portas (muitas vezes de metal), revestimentos e, inclusive, pisos, elementos que de formas variadas vão sendo integrados aos materiais tradicionais (tijolos de barro, engodo e pedras). A construção é feita seguindo o seguinte formato: o revestimento é feito em pedras, até aproximadamente um metro de parede acima do solo, nas áreas externas e internas. As pedras estão posicionadas de tal forma, que as primeiras (aquelas que dão a sustentação para as que irão subir) são colocadas na vertical, formando pilares; logo pedras menores são apoiadas sobre estas formando um revestimento sólido. Estas pedras são solidificadas às paredes com rejunte.

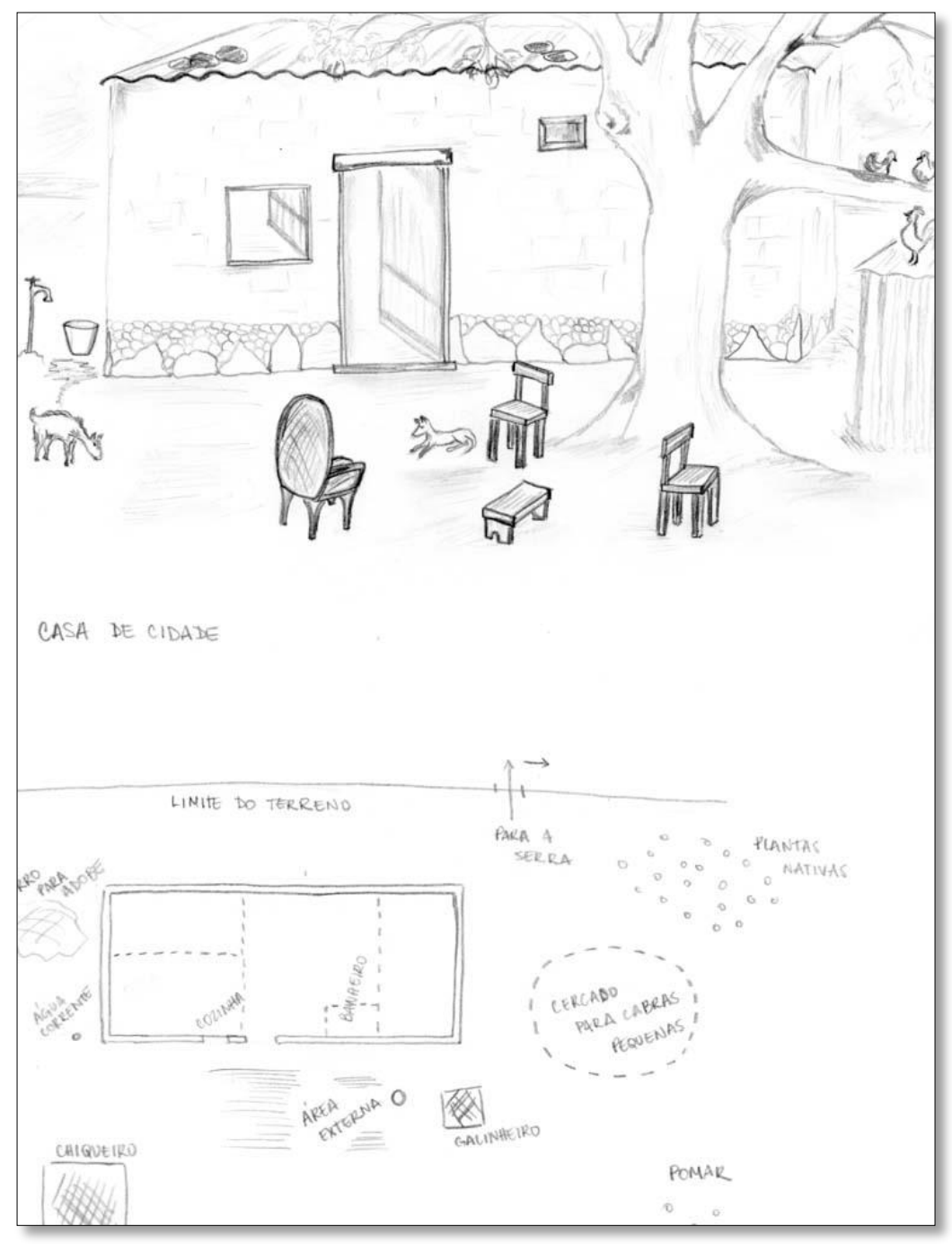

Figura 25 - Representação de uma casa de cidade.

No geral, a casa é dividida em três ambientes, sendo um cômodo central, conectado a uma cozinha interna, um ou mais quartos e um banheiro (estes dois últimos 
podem ser externos ou internos). Porém, isso não é uma constante, existem casas, como a de Guadalupe e uma das filhas de Dom Vicêncio, que o cômodo central (pelo qual se entra e os outros se conectam) é a cozinha. Ainda, no geral, a cozinha interna é pouco utilizada, dá-se preferência à área do forno que é externa e construída por pedras em forma de círculo onde se empilha a lenha e são apoiadas as panelas para cozer os alimentos.

Externos à casa, também existem pequenos cômodos telhados, com uma ou duas paredes (em formato de L) para guardar coisas. Estas casas possuem quintais, com aspecto de chácara, nos quais é possível encontrar currais para pequenos animais (p. ex. porcos e cabras pequenas), poleiros altos para as galinhas, árvores frutíferas e pequenas hortas. $\mathrm{Na}$ frente da casa, sempre há uma área com teto ou com árvores para a interação da família.

Pelas histórias que recolhi entre as pessoas que moram em Santa María e aqueles que moram no interior da serra, as casas na cidade são um fenômeno relativamente recente.

Ângela, a filha de Dona Maria, conta que eles foram morar mais próximo à cidade, na casa onde hoje habitam, quando ela tinha seis anos. Ela e os irmãos tinham de ingressar na escola e Don Vicêncio foi trabalhar durante a semana em San Miguel de Tucumán (a $185 \mathrm{~km}$ de Santa María). Las Mojarras é um bairro independente de Santa María. Tem a sua própria escola e igreja, o comércio também funciona de maneira local, os produtores (de pão, carne, verduras e frutas) passam nas casas regularmente oferecendo os produtos. Morar em Las Mojarras facilitou as coisas para eles pela facilidade da proximidade ao centro urbano, diz Ângela.

O caso de Guadalupe é parecido ao da família de Dom Vicêncio. Quando Guadalupe chegou à cidade, foi em busca dos empregos que o centro urbano oferecia, e lhe permitia criar os seus filhos com mais facilidade.

Em lugares como El Carmen, há escola e trocas locais que suprem boa parte dos produtos, porém não há empregos além dos que há no campo. A filha de Dom Yucra também passou por um processo parecido. Depois de casar, decidiu que as facilidades de Santa María eram mais vantajosas que permanecer no interior da serra.

Desta forma, ter um assentamento próximo à cidade parece responder a questões atuais do mundo moderno, da facilidade de escolas, comércio, hospitais e produtos em geral. São vários os casos como estes, vários dos vizinhos de Dom Vicêncio em Las 
Mojarras tinham se mudado para o bairro nos últimos cinquenta anos por motivos variados. Alguns porque ficaram doentes, ou porque ficaram idosos para ir e voltar e lhes faltava vários produtos importantes, ou porque os filhos entraram na escola etc. Desta forma, as cidades continuam "chamando" os pastores para as suas proximidades criando uma nova forma de assentamento que implica mudança de certos hábitos e estruturas básicas da household.

\section{2 - Casa de campo}

O segundo tipo de habitação são as casas de campo. Estas estão localizadas no alto da serra e são mais simples que as casas da cidade, porém, estão equipadas para morar ou receber a família, o que pode acontecer esporadicamente. Pelo que foi possível observar, existem duas estruturas para essas casas, existem algumas casas muito próximas em estrutura e tamanho às casas da cidade. Encontra-se este tipo de casa em El Carmen , no geral são casas mais antigas que sobreviveram ao processo de ida para os locais mais próximos às cidades, portanto, na sua maioria, estas casas encontram-se no interior das serras. 


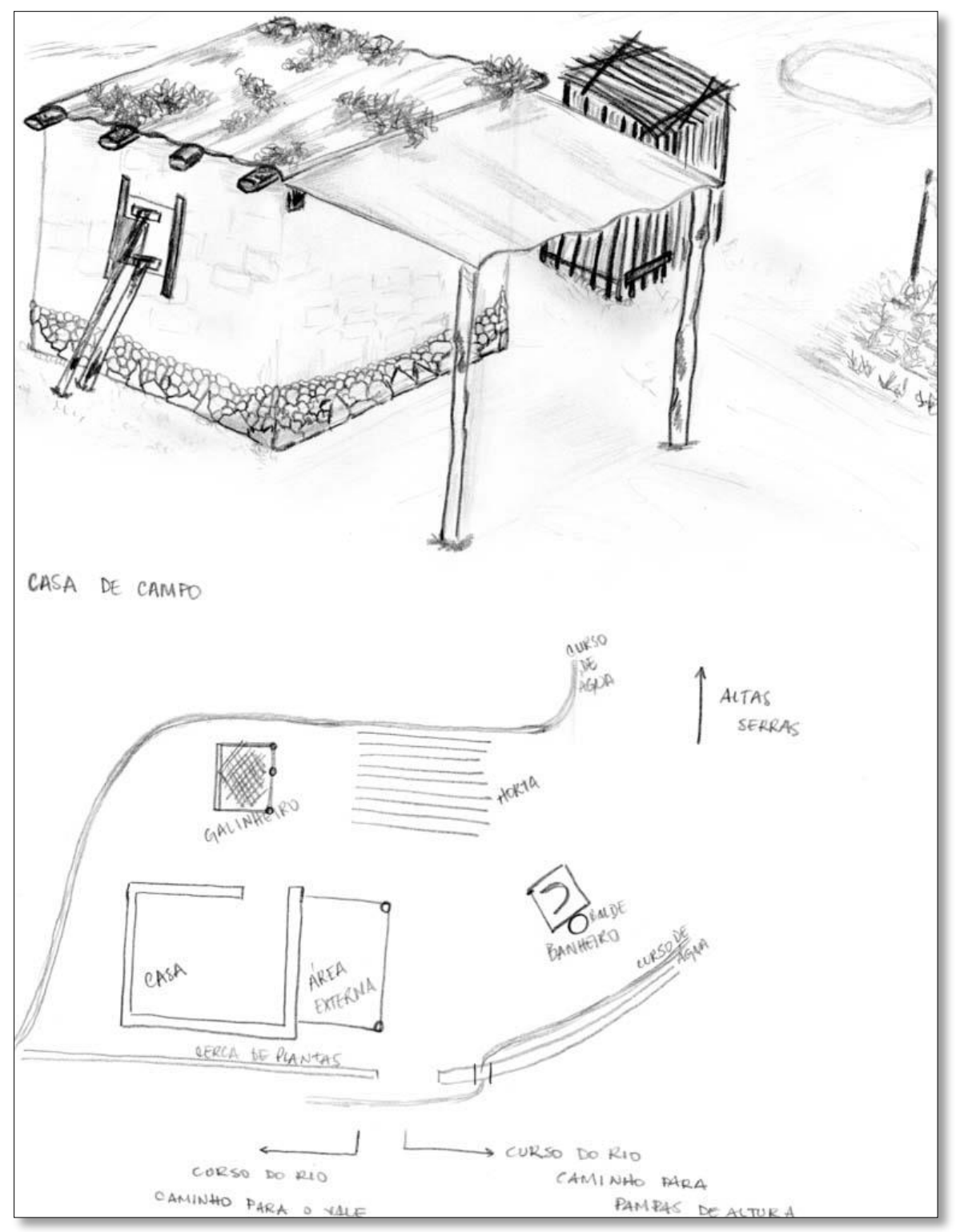

Figura 26 - Reprodução de uma casa de campo. No modelo que contém um único cômodo multifuncional.

O outro tipo são casas menores em metragem, com um grande cômodo central multifuncional, o qual serve para dormir e também para guardar as coisas. Talvez pela distância da cidade, a construção destas casas ainda é feita com materiais tradicionais encontrados nas montanhas. As paredes têm uma faixa inicial de pedra como a que está presente nas casas descritas anteriormente. A continuação da parede pode ser de engodo ou pedras e os telhados são de galhos de arbustos recobertos de barro. Algumas casas receberam tetos de madeira. O banheiro e a área de cozinha são externos e constam de um espaço aberto telhado, na entrada das casas. No entorno das casas de campo, podem 
ser encontrados chiqueiros, hortas e árvores frutíferas assim como é visto nas casas da cidade, isto acontece porque muitos pastores habitam nas casas de campo e não têm o referente na cidade, ou, se os tem, são de parentes, como filhos ou irmãos.

Não necessariamente quem tem uma casa de campo no alto das serras também tem uma casa na cidade. No geral, habitam uma das casas ou a outra. O que acontece é uma complementação familiar entre as das estruturas, por exemplo, Don Lorenzo mora em uma casa de campo no interior da serra e sua irmã Guadalupe tem uma casa na cidade, assim fazem uso das duas estruturas. O mesmo acontece com Don Yucra, que mora no interior da serra e a sua filha na cidade de Santa María. Dom Vicêncio, apesar de viver próximo à cidade, ainda tem a sua casa de campo, que está alugada para Dom Lorenzo. Ainda assim, quando vão com a família, alojam-se na casa de campo.

\section{3 - Postos temporários}




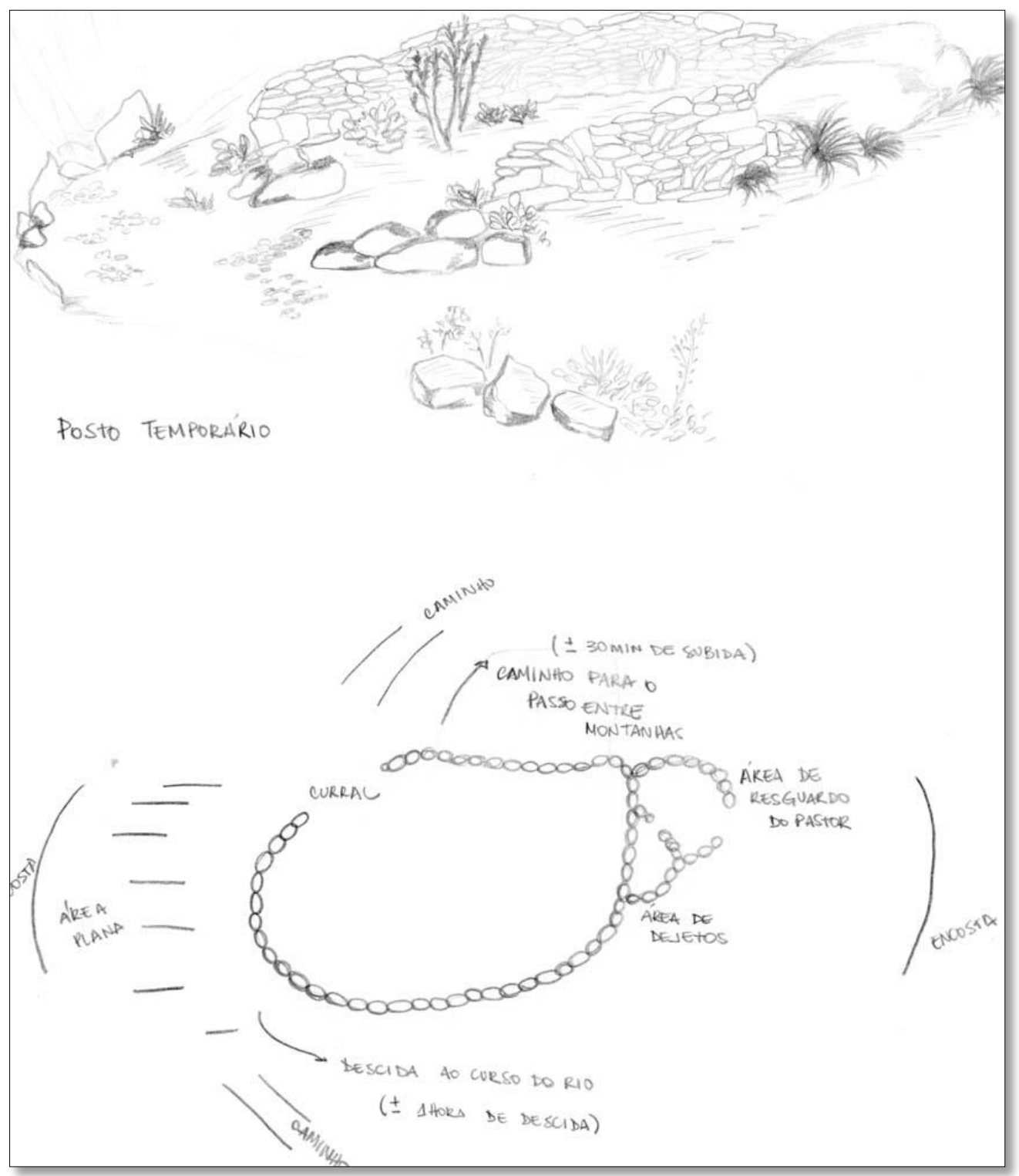

Figura 27 - Reprodução de um posto temporário do alto da serra.

O terceiro tipo de assentamento corresponde aos postos temporários. Estas habitações apresentam uma estrutura bem simples em relação aos outros tipos. Constituem-se de pequenas estruturas de pedras, no geral em formato de ferradura, com uma pequena abertura para entrar. Nem sempre contam com teto. A sua construção é feita com os materiais do local e das redondezas, não apresentam constância em tamanho, formato ou estilo. São utilizadas pelos pastores para guardar coisas ou passar um período muito reduzido dependendo do caso, por isso são restritas apenas ao espaço de resguardo de uma pessoa. 
Na sua maioria, estas estruturas servem para todas as funções: resguardo (quando é o caso) e estoque de coisas, porém existem algumas que se encontram associadas a outro pequeno recinto que é utilizado para estoque e descarte. Quando presentes, os postos temporários estão sempre associados a currais e pequenos plantios e estão localizados em regiões altas das serras.

Especificamente, este último tipo identificado de assentamento varia muito na sua presença e ausência, por isto é difícil defini-lo como um tipo específico. Ao lado da serra do Cajón que corresponde ao lugar onde moram Guadalupe e a família de Dom Vicêncio, Dona Maria me assegura que não é usual o pastor passar a noite fora. Como foi levantado anteriormente, durante os períodos secos, o pastor pode deixar os animais soltos no alto das serras, próximos a boas pastagens e olhos d'água, os animais se resguardam em currais, porém o pastor retorna à casa mais próxima voltando ou no dia seguinte ou em alguns dias. Já em locais como El Carmen, lado ocidental da serra do Cajón - mais seco e mais alto - os pastores diferem um pouco nesse comportamento. Em El Carmen, conversando com algumas pessoas do lugar, confirmaram que alguns ainda mantinham hábitos de ausentar-se por alguns períodos permanecendo ou pernoitando em postos temporários no interior das serras.

Os postos temporários variam em estrutura de acordo com o lugar e o período. $\mathrm{Na}$ zona de Dom Vicêncio, os postos temporários estão em altitudes menos elevadas e são utilizados, na sua maioria, para guardar ferramentas e coisas úteis. Já na zona de El Carmen, os postos temporários existiam para o resguardo do pastor, porém ainda há essas mudanças na utilização.

As serras de El Carmen estão repletas de currais espalhados. Apesar de que, à primeira vista, parecem locais de difícil acesso, todos estão conectados a caminhos. Os currais espalham-se das áreas menos elevadas até as mais altas, próximas aos picos da serra. Junto aos currais muitos apresentam postos temporários que, hoje em sua maioria, estão abandonados. Esses currais, nas regiões mais altas, continuam sendo utilizados como resguardo pelos animais (perceptível pois estão com presença de estrume de animal e a terra muito pisada e limpa de plantas), porém não mais como resguardo para os humanos. Ao que parece, estes currais no alto das serras acompanhavam resguardos para o pastor, pois estão próximos à linha do alto das serras e podem ser transitados com mais facilidade quando se quer cruzar de um vale a outro. Esses postos foram muito utilizados 
por pessoas que transitavam da puna aos vales ou vice-versa e esses currais na altura estão localizados em pontos que permitem alcançar os vales ou as partes mais altas.

Nos dias atuais, os postos temporários vêm perdendo a sua função de resguardo para os pastores, permanecendo com uma função de locais para guardar coisas ou como marcador de paradas para o descanso, porque os pastores já não estão permanecendo com tanta constância no interior das serras. Por outro lado, os currais continuam em uso, pois os animais continuam fazendo uso das pastagens e dos locais de água não perene do interior da serra.

Estas diferenças observadas em todos os tipos de assentamento, provavelmente respondem às mudanças na mobilidade dos dias atuais. Nas tabelas a seguir é possível observar estas mudanças de uma geração a outra.

\begin{tabular}{|c|c|c|c|c|}
\hline $\begin{array}{l}\text { Família -1 } \\
\text { geração }\end{array}$ & Casa na cidade & Casa no campo & $\begin{array}{c}\text { Postos } \\
\text { temporários }\end{array}$ & Localidade \\
\hline $\begin{array}{c}\text { Família 1 (pai } \\
\text { Vicêncio) }\end{array}$ & Não & Sim & Sim & Los Altos \\
\hline $\begin{array}{c}\text { Família } 2 \text { (pai } \\
\text { Maria) }\end{array}$ & Não & Sim & Sim & Santa María \\
\hline $\begin{array}{c}\text { Família } 3 \text { (pai } \\
\text { Guadalupe) }\end{array}$ & Não & Sim & Sim & Aguas Calientes \\
\hline $\begin{array}{c}\text { Famílias } 4 \text { (pai } \\
\text { Yucra) }\end{array}$ & Não & Sim & Sim & El Carmen (?) \\
\hline $\begin{array}{l}\text { Família } 5 \text { (pai } \\
\text { vizinho Yucra) }\end{array}$ & Não & Sim & Sim & El Carmen (?) \\
\hline $\begin{array}{c}\text { Família } 6 \text { (pai } \\
\text { Pepa) }\end{array}$ & Sim (próximo) & Não & Sim & Tafí del Valle \\
\hline $\begin{array}{c}\text { Família } 7 \text { (pai } \\
\text { Veterináro) }\end{array}$ & Sim (próximo) & Não & Sim & Tafí del Valle \\
\hline $\begin{array}{c}\text { Família } 8 \text { (tia } \\
\text { Guadalupe) }\end{array}$ & Sim (próximo) & Não & Sim & $\begin{array}{c}\text { Amaicha del } \\
\text { Valle }\end{array}$ \\
\hline
\end{tabular}

Tabela 10. Tipos de assentamentos representando a $1^{a}$ geração. Informação oral coletada.

\begin{tabular}{|c|c|c|c|c|}
\hline $\begin{array}{c}\text { Família -2 }^{\text {a }} \\
\text { geração }\end{array}$ & Casa na cidade & Casa no campo & $\begin{array}{c}\text { Postos } \\
\text { temporários }\end{array}$ & Localidade \\
\hline $\begin{array}{c}\text { Família } 1 \\
\text { (Vicêncio) }\end{array}$ & Sim & Sim & Não & Santa María \\
\hline $\begin{array}{c}\text { Família } 2 \\
\text { (Guadalupe) }\end{array}$ & Sim & Não & Não & Santa María \\
\hline $\begin{array}{c}\text { Família 3 } \\
\text { (Lorenzo) }\end{array}$ & Não & Sim & Sim & Santa María \\
\hline $\begin{array}{c}\text { Famílias 4 (filhos } \\
\text { Vicêncio) }\end{array}$ & Sim & Não & Sim & Santa María \\
\hline $\begin{array}{c}\text { Família 5 (vizinho } \\
\text { Vicêncio) }\end{array}$ & Sim & Sim & Sim & Santa María \\
\hline
\end{tabular}




\begin{tabular}{|c|c|c|c|c|}
\hline Família 6 (Yucra) & Não & Sim & Sim & El Carmen \\
\hline Família 7 (Pablo) & Não & Sim & Sim & El Carmen \\
\hline $\begin{array}{c}\text { Família } 8 \text { (vizinho } \\
\text { Yucra) }\end{array}$ & Não & Sim & Sim & El Carmen \\
\hline $\begin{array}{c}\text { Família } 9 \text { (filha } \\
\text { Yucra) }\end{array}$ & Sim & Sim & Não & $\begin{array}{c}\text { Santa María/El } \\
\text { Carmen }\end{array}$ \\
\hline Família 10 (Pepa) & Sim & Não & Sim & Tafí del Valle \\
\hline $\begin{array}{c}\text { Família } 11 \\
\text { (Veterináro) }\end{array}$ & Sim & Não & Sim & Tafí del Valle \\
\hline $\begin{array}{c}\text { Família } 12 \text { (irmão } \\
\text { Pepa) }\end{array}$ & Não & Sim & Sim & El Mollar \\
\hline
\end{tabular}

Tabela 11. Tipos de assentamentos representando a $2^{\mathrm{a}}$ geração. Informação oral coletada.

A tabela 10 indica os assentamentos referentes à primeira geração, referente aos pais dos pastores de hoje em dia. Nesta tabela, observa-se uma persistência de casas de campos - localizadas mais ao interior das serras - e a existência unânime de postos temporários relacionados a cada pastor. Na Tabela 11 as mudanças de geração são nítidas, há um deslocamento do local de habitação da família para mais próximo do centro urbano e muito pastores perdem os postos temporários.

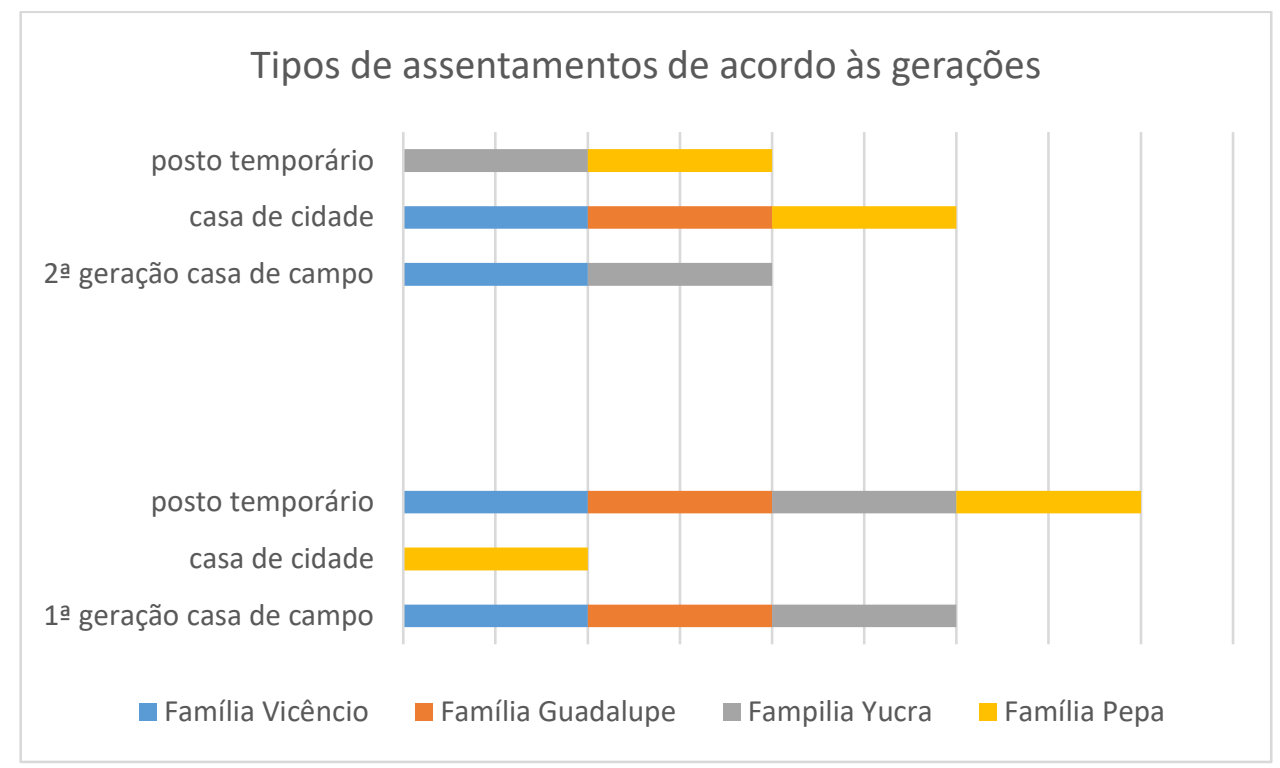

Figura 28. Gráfico representando os tipos de assentamentos. O primeiro conjunto representa a geração atual, mostrando uma mudança entre a casa da cidade e a casa de campo, o segundo conjunto representa a geração anterior à de hoje, indicando uma persistência nas casas de campo e de postos temporários. 
De acordo com o gráfico parece haver uma relação entre a existência de um centro urbano nas proximidades e a inversão entre as casas de campo e as casas na cidade. É possível observar uma mudança entre as famílias que se mudaram para próximo ao centro urbano entre a primeira e a segunda geração (Famílias de Dom Vicêncio e Guadalupe), enquanto aquelas famílias que permaneceram mais distante aos centros urbanos continuaram com os assentamentos no interior das serras (a família de Dom Yucra, por exemplo, que indicará uma mudança apenas da terceira geração). Ainda assim, é possível considerar as casas na cidade como um desdobramento moderno das casas de campo. Do mesmo modo, existe uma mudança no uso dos postos temporários. Porém, nenhuma destas novas opções de uso do espaço, ao que parece, tem afetado diretamente a atividade pastoril. Tanto na estrutura e uso dos assentamentos, como em outras áreas, as transformações do pastoreio moderno são visíveis. Cada vez mais, os pastores vêm adotando - por conveniência e porque estão sendo empurrados - as tecnologias modernas, práticas veterinárias, orientação à economia e necessidades do mercado, questões que estão transformando as paisagens e o seu cotidiano. Porém, ainda com esta modernização, as pessoas encontram meios de preservar a sua forma de vida.

O que se considerou neste capítulo sobre a mobilidade pastoril foi, primeiramente, o padrão ambiental de acesso às diversas áreas de captação e também as relações socioculturais que tomam forma e, ao mesmo tempo, ordenam essa mobilidade. Assim, a ordem do pastoreio e as atividades cotidianas ordenam: o tempo em larga escala, os tipos de assentamento e as relações com o espaço vivido, tanto no âmbito cotidiano como na prática de uso da terra e seus recursos. 


\section{4 - CAMINHOS E LUGARES. Uma introdução aos elementos da paisagem pastoril.}

Nos capítulos anteriores foram apresentadas aas características do sistema pastoril vigente em Santa María. Como se trata de um pastoreio tradicional com mobilidade os caminhos e os lugares são essenciais nesse sistema.

Neste capítulo se irá discorrer sobre os elementos que constituem essa paisagem pastoril. A partir do movimento, o conhecimento das pessoas é elaborado e permeado por esses elementos. Os quais contextualizam o meio à volta e estabelecem normas de comportamento e significação da vivência.

\section{1 - Introdução}

O capítulo anterior trouxe informações sobre o tipo de mobilidade e as implicâncias estruturais que os movimentos trazem. Definiu-se o movimento dos pastores de Santa María sem mobilidade residencial, apenas apresentando uma mobilidade logística distinguida em três tipos: $1^{\circ}$ ) movimentos de curta distância; $2^{\circ}$ ) movimentos de médias distâncias; $3^{\circ}$ ) movimentos de distâncias longas, sendo estes mais raros e pontuais para algumas zonas nos últimos anos. Aliados, estes movimentos apresentam uma relação 
com a sazonalidade e consequente percepção do meio, como é indicado no quadro a seguir:

\begin{tabular}{|c|c|c|}
\hline Movimento de verão & Movimento de inverno & Caravanas \\
\hline - estação chuvosa; & - estação seca; & - estação seca; \\
\hline - zona baixas dos vales; & $\begin{array}{l}\text { - zonas mais altas, interior } \\
\text { das serras; }\end{array}$ & \\
\hline $\begin{array}{l}\text { - movimentos curtos, } \\
\text { próximos à residência fixa; }\end{array}$ & $\begin{array}{l}\text { - movimentos com distâncias } \\
\text { intermediárias, mais distantes } \\
\text { da residência fixa; }\end{array}$ & - movimentos longos; \\
\hline $\begin{array}{l}\text { - uso de pastos de estação, } \\
\text { secam e/ou morrem com o } \\
\text { fim da temporada chuvosa. }\end{array}$ & $\begin{array}{l}\text { - uso de pastagens } \\
\text { persistentes, em zonas que } \\
\text { ainda se mantêm férteis. }\end{array}$ & $\begin{array}{l}\text { - intensão de alcançar os } \\
\text { mercados e não pastagens. }\end{array}$ \\
\hline
\end{tabular}

Tabela 12 - Resumo dos movimentos pastoris.

Portanto, a mobilidade pastoril implica em determinadas características que ditam o ritmo da vida. $\mathrm{O}$ ambiente tem importante influência na definição dos ritmos e escalas, que, juntamente com o movimento, condicionam as formas de assentamento e aproximação ao espaço. Este espaço habitado representa uma série de características comportamentais que são plausíveis de serem identificadas e analisadas.

Habitar é o princípio formal em relação ao ambiente, é a criação de possibilidades de adaptação e aproximação ao ambiente ao redor, por exemplo, criando-se abrigos para proteção e reduzindo-se a exposição. Construir e habitar é o primeiro processo de significar o "existir no mundo", é um processo que obriga o humano a interagir diretamente com o meio, observando e adaptando-se às condições ambientais, de acordo com as necessidades humanas e individuais. Isso gera identidade, pois habitar também é um processo de significação (Botin 2013).

Pensar na mobilidade pastoril, obrigatoriamente exige pensar nas questões da paisagem e nos traços desse movimento. Isto implica a relação das pessoas com o meio ao redor, considerando-se aspectos de significação e os significados que são impressos na 
integração homem/terra. Faz-se necessária a compreensão de ambos (significado e significação) para entender em que consiste mover-se pelos caminhos e lugares, pois, no movimento, as pessoas viajam através da paisagem. O processo de mover-se é também o de habitar essa paisagem, assim como "caminhar" por um caminho torna-o familiar. Conforme é utilizado, o próprio caminho torna-se parte do caminhante (Botin 2013).

Todos estes processos presentes na construção de uma paisagem pastoril do ambiente de Santa María exigem ampliar alguns conceitos para se compreender o processo que se está analisando. Portanto, primeiramente, serão abordados os conceitos de paisagem e dos temos adjuntos, como espaço, lugar e vetores indicadores, para que se possa compreender a percepção e a apreensão dessa paisagem pelos pastores do vale de Santa María.

\section{2 - A conceptualização da paisagem}

Para dar início à discussão, é preciso definir o que se compreende como paisagem. O termo paisagem tem -se tornado vago e ambíguo, pois apresenta várias significações. No geral, as definições de paisagem variam, pode significar a representação de um cenário; pode ser compreendida como arte, representando uma paisagem pintada em um quadro ou fotografias; entendida como o universo exterior, campos arados, florestas, montanhas, lagos, prados etc. O termo paisagem também é utilizado como sinônimo de vista, para retratar aquilo que está diante dos olhos, à distância. Desta forma, na conjuntura de todos estes significados, pode-se pensar que o termo paisagem é a representação de algo amplo e vago que se mimetiza com o horizonte e integra diversos elementos.

Isso quer dizer que, apesar dos diversos conceitos, a paisagem sempre é representativa (indica um valor representacional em relação a um determinado conteúdo pelo qual é integrada). Por ser representativa, não há como se falar de paisagem sem retratar a intervenção humana, pois é a partir da ação humana que se cria, representa e se reproduz a paisagem a partir dos componentes integrados - humanos, extra-humanos e ambientais - os quais são também rearranjados e reinterpretados de acordo com as intenções e os múltiplos significados (Botim 2013). Neste sentido, a paisagem é sempre 
caraterizada pelas diferentes escalas culturais, pode ser adjetivada e entendida de diversas maneiras, refletindo as necessidades e intenções dos grupos.

É possível, inclusive, identificar áreas de atividade com uma paisagem mítica, da qual fazem parte elementos extra-humanos, como é o caso dos Asurini (Pará, Brasil). Para este grupo indígena, os materiais da paisagem são testemunho dos diversos eventos míticos, diante dos quais interpretam e dão sentido à paisagem que os rodeia (ver Silva 2002). O mesmo pode ser descrito para os grupos Hopi (Estados Unidos), para os quais os marcos da paisagem são testemunhos vivos dos eventos míticos que culminam em uma série de atividades nos dias atuais, inclusive caminhadas (ver Zedeño et al 2009). Estes são apenas algumas dos diversos exemplos que permitem entender a paisagem como algo extremamente fluido e interpretado culturalmente.

Nas definições da UNESCO (Organização das Nações Unidas para a educação, a ciência e a cultura), a paisagem é associativa e projetada. A UNESCO define a paisagem como o oposto à terra abandonada, pois exige que se mantenha a ação social em constante progresso e resistência no mundo contemporâneo, sendo o material a prova dessa progressão histórica. Nesta perspectiva, paisagem tem a ver com lugar, este é influenciado e transformado pelos humanos e também está exercendo influência na ação e no pensamento humano, tanto a partir do que existe no presente como desde o passado. Portanto, na paisagem, os elementos complementam-se e integram-se, em contínuo fluxo e transformação, pois ela é designada e recriada pela ação humana, considerando-se que, tanto os elementos materiais, quanto os não materiais representam um papel para a constituição da paisagem (Quesada-Embid 2008).

As definições da paisagem implicam em duas questões que obrigatoriamente caminham juntas: uma perspectiva ambiental e uma perspectiva social e cultural. Focar no impacto humano e nas interações entre humanos e o meio que os rodeia permite enfatizar questões como subsistência, adaptabilidade, dinâmicas inter-regionais, determinantes econômicos dos padrões de assentamento e impactos ambientais, todavia, sem negligenciar questões como construções e significações dos espaços e monumentos, modos de produção e proteção de áreas históricas e sítios arqueológicos, entre outros. Em todo o seu processo de desenvolvimento como categoria de análise, os estudos sobre a paisagem apresentam uma preocupação pós-moderna com a representação e a construção simbólica e ideológica, que têm levado a repensar a paisagem como algo adaptativo e a 
incluir fatores sociais em sua análise. Esta mudança de perspectiva promoveu grandes alterações que influenciaram o modo de se entender a própria paisagem e a relação da arqueologia com as comunidades (David e Thomas 2008).

Como caracterização humana, a paisagem é sempre perceptiva e os elementos humanos estão tão integrados aos elementos do ambiente que a presença humana não é facilmente separável, portanto exige uma análise integradora (Quesada-Embid 2008). Assim, a paisagem não pode ser vista como neutra, mas ideologicamente construída e com sua estrutura em constante mudança. Como construção social, parte de um processo que implica em sua identidade. Ao mesmo tempo, é algo integrado e como elemento ativo na dinâmica da vida (Hirsch 1995; Feld e Basso 1996).

Esta perspectiva refere-se ao espaço como lugares humanos em toda a sua existência e fenomenologia, onde se identifica a história e a historicidade das diversas identidades que ali sobrevivem. Assim, considera-se o lugar como meio e fruto de interações dos diversos processos sociais ali envolvidos, considerando-se a própria história e modo de vida daqueles que habitam esses lugares. Portanto, é fundamental buscar noções e perspectivas das comunidades tradicionais e suas relações com a cultura material do local, levantando-se as configurações simbólicas e ambientais implicadas. Desta forma, os sítios podem ser encarados como referentes culturais e locais ancestrais (David e Thomas 2008).

Estas direções teóricas sobre uma perspectiva de paisagem simbólica e mais fenomenológica levantaram alguns questionamentos. No que concerne à apreensão do entorno, considera-se que cada construção de mundo é cultural e particular, sendo que a expressão da cognição ou dos significados no ambiente responde a uma ordem subjetiva, circunstancial e contextual (Layton e Ucko 1999). Por sua vez, lugares representam significado, eventos e a materialização de certas subjetividades culturais. Compreende-se por lugar algo mais amplo que apenas os locais geográficos, lugares podem representar inclusive caminhos, são espaços com significado que integram os sistemas adaptativos ao ambiente, a organização logística dos grupos e questões cognitivas específicas (Casey 1996).

Assim, a arqueologia da paisagem ainda é uma "arqueologia do lugar", porém como um lugar humano, um espaço que integra o comportamento, seus produtos materiais 
e a memória que os implica. Construir lugares é uma maneira de dar forma ao passado e dar significado, produzindo história (Zedeño e Bowser 2009).

Nos trajetos, através da paisagem, uma série de possibilidades se integra. Cada local faz parte dessa rede dinâmica que é a paisagem (não são pontos específicos ou isolados), considerada em seu conjunto. É fundamental considerar trilhas, caminhos e estradas como lugares integrados e integradores, que constituem o ambiente determinado por um grupo específico. Eles são plausíveis de serem analisados como qualquer outro artefato ou estrutura pela arqueologia tradicional (Ingold 2012).

Desta forma, não é possível reduzir caminhos e lugares a apenas pontos no mapa - como se tende a fazer na hora de demarcar um sítio ou um monumento histórico -, é fundamental considerar o dinamismo da paisagem para compreendê-la no presente e no passado humanos. Isto porque, os caminhos e trilhas, neste contexto, são compreendidos a partir do fluxo. O começo e o final são representados apenas pelos destinos escolhidos pelas pessoas, porém os trajetos se estendem e se conectam, criando uma intensa rede vital de toda a paisagem em movimento. Desta forma, os caminhos também indicam territórios que, ainda que descontínuos, são redes regionais de relações entre pessoas e o ambiente e que constituem a rede do que se compreende como paisagens do movimento (ver Zedeño 1997).

Os estudos sobre a paisagem permitiram expandir este horizonte, principalmente no que concerne às paisagens do movimento, pois é fundamental o dinamismo da paisagem (Snead et al 2009). Todos os elementos da paisagem, na sua condição dinâmica e fluida, são representados por paisagens do movimento, que representam o contexto do próprio movimento humano através da paisagem, envolvendo a ação do habitar e transitar na paisagem. Estes estudos sobre as paisagens do movimento não se restringem aos últimos anos. Na América Latina, esses estudos, inicialmente, focaram-se nos considerados Estados pré-colombianos e nos Impérios. Exclusivamente nos Andes, estes estudos focaram-se nas rotas incaicas e no complexo sistema regional e local que os incas criaram. Apesar de que ainda há muitos trabalhos focados nestas perspectivas, na atualidade, tem- se expandido o interesse por paisagens indígenas do movimento (Snead et al 2009).

O movimento pela paisagem, portanto, conecta as pessoas aos aspectos fisiográficos e aos recursos naturais do meio. Distinguem-se diferentes tipos de 
movimento: os movimentos do cotidiano, que representam as práticas e as necessidades do dia-a-dia; os movimentos extraordinários, que respondem a viagens específicas que não são feitas com tanta frequência e também aqueles movimentos que podem ser considerados lúdicos, como passeios, ou viagens que visam fazer que as crianças ou alguém de fora venha a conhecer certos lugares, caminhos e maneiras de apreender a paisagem. Assim, o processo de mover-se pela paisagem implica diretamente em construção de identidade. No movimento, novos conhecimentos são inscritos e integrados aos velhos, por meio de símbolos e da história. Neste processo, retoma-se uma memória e impõe-se um comportamento particular, os quais geram lugares específicos plausíveis de serem identificados pelo grupo (Zedeño et al 2009).

Diante disto, é fundamental romper com os conceitos que caracterizem a paisagem como estática e imutável e buscar compreender a paisagem pelo seu todo, considerandose a fluidez, a mobilidade e o movimento em termos de espaço e lugar dento dos conceitos e interpretações de cada grupo, inclusive considerando-se as influências externas que culminam nesses processos (Feld e Basso 1996). Assim, a antropologia tem ressaltado: a) a particularidade cultural dos grupos específicos e b) a referência a partir dos significados criados pelas pessoas para o seu entorno. A paisagem, portanto, é primeiramente o que se vê e o que os grupos reconhecem por meio da apreensão dos sentidos dados e das práticas cotidianas. A paisagem é plausível de ser reconhecida a partir da descrição e interpretação, pois é uma visão a partir de como e do que se simboliza do meio ao redor (Hirsch 1995).

\section{1 - Conceptualização de espaço, de lugar e de movimento}

\subsection{1 - Sobre como utilizaram-se os conceitos de espaço e lugar}

Através dos movimentos cotidianos das pessoas e das atividades do dia-a-dia, estabelecem-se as estruturas e noções do que se considera lugar e outras formas mais abstratas de representação (Erickson e Walker 2009). Diante disto, é fundamental definir a partir de quais perspectivas faz-se a análise espacial desta tese, assim como, definir a noção de espaço e, consequentemente, a de lugar, uma vez que existem diferentes nomenclaturas e definições específicas daquilo que os autores consideram lugar e espaço. 
Assim, como a paisagem, a expressão 'espaço' também é vaga. Tem sido identificada como porção específica da superfície da Terra, como natureza, como as marcas do homem ou, ainda, como referência à localização. Este conceito vem associado a diferentes noções de escalas, que podem se referir desde a uma rua ou cômodo de uma determinada casa, até um continente ou porção do globo terrestre.

Nas últimas décadas, os geógrafos adotaram marcos teóricos mais interpretativos, muito próximos aos dos antropólogos, desde uma nova ótica moldada pela diversidade cultural, da qual emergiu uma perspectiva de espaço que considera as experiências vividas e os contextos socioeconômicos específicos. Esta perspectiva de uma geografia mais humanista é pautada pela subjetividade, pela experiência e por percepções e sensações. Deste modo, toda espacialidade é carregada de simbolismo, o espaço é compreendido a partir dos sentimentos espaciais e das experiências de um determinado grupo sobre um determinado espaço (Haesbaert 2002).

Tomar um conceito de espaço como aspecto simbólico permite alcançar a versatilidade do próprio conceito, considerando-se vários tipos de espaços: espaços pessoais, espaços de grupo, espaços onde é vivida a experiência do outro, espaços míticoconceituais. O espaço, portanto, é compreendido como a experiência contínua do ser e do social, um espaço em movimento que é campo das representações simbólicas. Considerase que um mesmo espaço pode revelar diferentes significações de acordo com a apropriação dos signos, sendo que, a espacialidade apresenta uma dimensão concreta e uma dimensão simbólica em diferentes intensidades, pois os símbolos não se impõem apenas como uma necessidade natural, eles mantêm uma referência ao real, ainda quando são pautados na ordem sociocultural (Corrêa e Rosendahl 2008).

Desta forma, pensar em um espaço implica em ver as diferentes facetas de um mesmo fenômeno, que não é unidimensional, é um tecido de redes complexas de apropriações e significados que funcionam de maneira dinâmica. Estas diferentes facetas do espaço corresponderiam à materialização das diferentes leituras que os grupos específicos produzem. A problemática espacial considera as derivações da totalidade, a partir da noção de espaço como integradora de vários lugares, sendo cada lugar parte do todo. Contudo, essa totalidade não é percebida explicitamente, ela existe a partir dos lugares que apresentam uma identidade própria, cada lugar existe como específico para cada um que o apreende (Haesbaert 2002). 
A conceptualização de espaço na perspectiva antropológica tende a centrar-se nas identidades sociais, no senso de pertencimento a um determinado lugar e tendo em vista as relações locais e extra locais. Considera-se a multiplicidades das vozes locais. Assim, áreas geográficas são representações construídas; os territórios, as fronteiras e a própria definição dos espaços é sempre contextual, porosa e fluida (Feld e Basso 1996).

Os diversos significados dados pelos humanos ao meio à volta integram sentimentos, sensações, conhecimento e cultura, desde uma perspectiva do sentido do lugar $^{21}$. Esta perspectiva toma a ideia de dwelling de Heidegger (1971). Consideram-se as múltiplas inter-relações vividas entre pessoas e lugares e, pela simples existência dessas relações, o espaço passa a ser e ter significado. Desta forma, o espaço recebe as noções de significados e localização a partir das pessoas (não é algo do próprio espaço), as relações com os lugares são vividas em/entre/pelos lugares e assim o lugar transformase no objeto da reflexão humana. Nesta perspectiva, a paisagem é o movimento cotidiano que dá sentido e conceitualiza, da mesma forma que caminhos, à primeira vista, parecem irreconhecíveis aos olhos não "treinados", porém com a constância e o conhecimento são reconhecíveis e distintivos entre si, a partir de uma série de características e informações subjetivas (Basso 1996; Botim 2013).

Na perspectiva fenomenológica, o ponto central em matéria de lugar é o papel da percepção. A percepção gera conhecimento (porque é experienciável), porém os lugares, muitas vezes, provocam sensações e expectativas muito mais profundas dentro do arcabouço geral das percepções das pessoas, impulsionando as sensações, os sentidos, as impressões etc. Por sua vez, a percepção existe no processo do ser e do mover-se. Atribuir significado a um local é um processo social e cognitivo, em que o lugar passa a existir através de um imaginário espacializante, um nexus entre a significação imaginada de um sítio e as suas intersecções com a representação real desse sítio (Whitridge: 2004: 214).

Parte do que constitui um lugar provém da motivação e do dinamismo. Este último existe em várias escalas: estar no lugar, mover-se pelo lugar, mover-se entre lugares. Desta forma, os lugares representam mais que posições fixas, representam conexões. Os corpos vivos em movimento são essenciais para o processo de constituição dos lugares. Nessa reação, os lugares também são repositórios de experiências, histórias, diversos

\footnotetext{
${ }^{21}$ Tradução do inglês de "sense of place" (ver Feld e Basso 1996).
} 
traços culturais e até pensamentos e ideologias, pois as características físicas de cada lugar associam-se a memórias, expectativas, projeções e reproduções, condicionando todo um arcabouço que faz sentido para aqueles que o identificam como tal (Casey 1996; Ingold 2012).

Diante disto, os lugares apresentam uma configuração particular, que reflete o esquema desse lugar na paisagem. Por exemplo, as montanhas unem-se ao significado depositado nelas, formando um lugar pela relação que existe entre as "coisas" contidas ali. Assim as montanhas e serras são repositórios de eventos e não simplesmente amontoados de terra e rochas. Os lugares são os repositórios desses diversos eventos e informações que ali aconteceram e que continuam acontecendo. Assim, como evento, o lugar é algo único - não é universal nem fixo - pois os lugares acontecem e são caracterizados e construídos pelas pessoas.

Porém, além de distintivos e experienciáveis, os lugares também provam serem universais, pois fazem parte da generalização de uma região definível a partir das características que as diferentes pessoas lhes atribuem. Ao mesmo tempo em que se define uma região, essa generalização é feita a partir dos lugares particulares que a integram. Assim, lugares são contingência, dependendo da escala em que são abordados, representam diferentes graus de generalizações e particularidades (Casey 1996).

Os lugares são a forma como as pessoas incorporam na paisagem sensações, sentimentos, conhecimento e cultura, tornando a paisagem algo experienciável e parte do habitus. As pessoas, no fluxo cotidiano, acessam os lugares promovendo uma relação vivida com o espaço geográfico, no qual este é internalizado, significado e integrado às próprias pessoas. Assim, a paisagem é uma simbolização do meio que permite ser apreendido e reconhecido como próprio. Esse processo implica aproximação e identidade, pois as ideologias e a as formas culturais de ver o mundo têm um papel fundamental na simbolização da paisagem (Gow 1995).

Desta forma, não é possível partir de um ambiente vazio esperando por configurações culturais para ser preenchido, as transformações são feitas sobre o palimpsesto dos diversos eventos que acontecem nos lugares, porque a experiência dos lugares é recíproca e dinâmica, a qual cria um processo de internalização da paisagem, que relaciona diretamente espaço à familiaridade, às experiências e aos significados 
atribuídos. Este fenômeno indica a maneira como as pessoas interagem, representando a constante performática que reproduz e expressa o senso de lugar próprio (Basso 1996).

\subsection{2 - Sobre o conceito de lugar e movimento}

Como se está utilizando uma perspectiva de paisagens do movimento, espaço e lugar aqui são representados por ordens espaciais dinâmicas, como trilhas, caminhos e locais que implicam na vasta rede fluida do cotidiano pastoril. Portanto, ao se falar de lugar, considera-se que implica diretamente em movimento, pois a vida é vivida e conhecida entre lugares, no trajeto entre um lugar e outro (Ingold 2012).

Neste contexto, viver em um lugar não significa habitar um local fixo, mas sim no movimento contínuo dos trajetos que unem os diversos lugares. Pastores como Dom Vicêncio, por exemplo, habitam a cidade de Santa María. Mas, ao mesmo tempo em que Dom Vicêncio vive na casa em Las Mojarras, também viveu um processo de movimento pelo interior da serra do Cajón, atravessando os diversos lugares que fazem parte do seu cotidiano. O processo de movimento integra toda a vida, portanto não é um movimento de uma ida ou volta, mas é uma forma de viver e, consequentemente, abstrair o espaço e o tempo nesses vários lugares pelos quais se transita/habita.

Mover-se e habitar os lugares também é o processo pelo qual se apreende e se transforma a paisagem (Ingold 2000). Isto porque, a vida não é vivida dentro do lugar (por exemplo, em um quarto, cozinha ou escritório), mas através e ao redor, no movimento entre todos os lugares. Desta forma, os lugares são delineados pelo movimento das próprias pessoas. É nesse processo que se circundam os limites, através de trilhas e vias criadas pelo fluxo contínuo de seres vivos (Ingold 2012).

Portanto, na conceptualização do que é lugar são incorporadas - e consideradas as definições que englobam os instrumentos de navegação. Estes instrumentos são marcas da identidade de cada sociedade, uma vez que, a percepção espacial não é única, universal ou objetiva, é particular, histórica e culturalmente inteligível (Whitridge 2004).

Habitar um lugar é movimentar-se por um ambiente e reconhece-lo. Percebe-se o ambiente por esse processo de habitar que além da locomoção também implica em ver, ouvir e construir. $\mathrm{O}$ conhecimento que existe nas informações acumuladas permite criar 
uma imagem mental dos lugares, dos trajetos e dos elementos apreendidos que condicionam a região conhecida. Isso porque, percebe-se a paisagem através de uma série de pontos pelos quais se habita (se caminha e se vive). Portanto, a paisagem nada mais é do que a cristalização de uma atividade em um campo relacional. Na vida cotidiana, marcam-se os passos dos caminhos, elementos e feições que são incorporados à própria capacidade do movimento. É através do caminhar que a paisagem se transforma em paisagem habitada (dwelling), pois a vida está se movimentando pela paisagem em um processo que é contínuo e que nunca acaba (Ingold 2011).

No processo de reconhecer lugares no espaço, observou-se outra questão que permeia toda esta discussão: não importa quão distante - em tempo ou espaço - os pastores estivessem, ao falar de lugares e caminhos, o processo implicava automaticamente em uma paisagem conhecida e já integrada ao cotidiano, na qual até mesmo uma rocha estaria carregada de informações de direções e histórias de vida.

\section{3 - Narrativas de trajetos}

O pastoreio é o conceito central de grande parte dos movimentos que são narrados, principalmente no que concerne ao espaço das serras. Assim, ao se contar sobre locais e caminhos, a maioria das informações retratava caminhos e histórias de pastores.

Os caminhos estão por todas as partes. Faz-se um determinado caminho para chegar ao centro da cidade, para chegar ao mercado, à casa de um vizinho etc. Porém, os caminhos de interesse central desta tese são aqueles que têm uma função dentro do sistema pastoril.

Uma questão a ser destacada é a capacidade destas pessoas de construir um mapa mental a partir de memórias. Nesse mapa, estão contidos todos os caminhos e lugares que consideram importantes, os quais são acessados facilmente juntamente às histórias que carregam. Desta forma, a percepção das direções e dos trajetos está pautada por uma memória e por determinados elementos que são os indicativos de tais caminhos.

Sobre o ato de caminhar, não é apenas o movimentar-se, caminhar também é um ato sociológico, é uma atividade visual na qual se percebe todo o ambiente, são checadas as direções com antecedência e, sempre que necessário, se fazem ajustes (Ingold 2011). 
A forma como os grupos acessam a informação sobre caminhos e trajetos não é universal, é perceptiva e sociocultural, respondendo a um contexto específico de símbolos que são identificados e naturalizados. No caso de Dom Vicêncio, mapas e fotografias aéreas não foram válidos no reconhecimento da região ${ }^{22}$, porém simples fotos automaticamente retomavam, na memória de Dom Vicêncio, certos locais e caminhos. A memória de Dom Vicêncio era "acionada" com os elementos que estavam presentes nas fotografias, tais como rochas, cercados ou porteiras, especificidades do terreno etc. No processo de reconhecimento dos lugares, Dom Vicêncio não utilizava nomes, mas trajetos que conhecia mentalmente para indicar os locais que as fotografias indicavam. Desta forma, locais não eram apenas sítios estáticos, mas um processo de movimento para alcança-los.

Isto porque, os sensores do corpo de direção não são limitados à presença dos corpos, constituem-se como experiências locais para estabelecer pontos e lugares de contato entre o físico e o arcabouço de percepções. A experiência vivida gera constantemente interações sensoriais e correspondência que fazem que as pessoas internalizem a paisagem à volta e se adaptem (Feld 1996).

\section{1 - Trajetória e localização: sobre os vetores no espaço}

O conhecimento dos lugares não é subsequente às percepções, mas um dos pontos da própria percepção, porque conhecimento é experienciável no processo de habitar. Por sua vez, a percepção existe nos processos de existir do corpo, que sente e se move. O lugar também tem influência, a qual é significativa, assim, lugares integram corpos tanto quanto os corpos integram os lugares. O corpo humano é essencial para se orientar, orientar-se nos lugares, entre e pelos lugares, pois o corpo tem intencionalidade e esta intencionalidade, com o corpo em movimento, integra corpo, movimento e ambiente, concretizando os eventos nos lugares específicos (Casey 1996).

A ciência espacial ocidental também segue este mesmo princípio, mas o faz de uma maneira diferente. Isto acontece porque, a espacialidade humana é sempre

\footnotetext{
${ }^{22}$ Uma das propostas da pesquisa de campo de 2014, junto ao Projeto Cajón, era a de demarcar sítios arqueológicos antigos - já explorados, porém a alguns anos sem novas visitas - e de identificar novos sítios. A proposta era projetar alguns mapas de relevo e fotografias de satélite aéreos da serra do Cajón para Dom Vicêncio, com o intuito que ele pudesse identificar os locais. Infelizmente os locais esperados não puderam ser identificados, mas a dinâmica rendeu uma série de resultados.
} 
heterogênea e complexa, sempre historicamente articulada e incorporada pelas pessoas junto ao contexto simbólico, social e de um mundo biofísico específico (Whitridge 2004).

A convenção cartográfica, à qual nós ocidentais estamos acostumados, define uma perspectiva pela qual se concebe a superfície da terra dividida em mosaicos de propriedades privadas, ocupadas e nomeadas por nações de diversos grupos étnicos. Alguns grupos não consideram a ocupação da terra como um país ao qual se pertence. Determinados grupos existem na superfície total da sua nação, onde se movem através de caminhos que ligam lugar a lugar. Assim, vivem em todo lugar, e não em lugares específicos. Esta noção implica em um entrelaçado de trilhas nas quais as pessoas vivem (ver Ingold 2012).

Desta forma, por ser um reflexo da ordem cultural de cada grupo, é possível encontrar a espacialidade nos relatos cotidianos. Nessas narrativas, encontram-se informações do meio e das ações das quais derivam lugares conhecidos e trajetos caminhados. No processo de narrar trajetos, organiza-se o processo de caminhar, pois a narração representa a lembrança da própria caminhada. Os percursos e os mesmos movimentos são refeitos mentalmente, pois a memória do caminho é aquilo que os pés executaram ao andar (De Certeau: 2000:128).

Os relatos acionam a memória e trazem lembranças de lugares e acontecimentos que condicionam a noção de espaço de quem está contando, tornando explícita a ordem dos lugares que se concebe. Considerando-se um relato oral, é possível distinguir os códigos que as pessoas estão utilizando para definir essas classificações da ordem espacial, além de perceber as práticas espacializantes dessas pessoas. Isto quer dizer que, a partir dos relatos, pode-se analisar as estruturas culturais que guiam as ações de movimento e localização, assim como aconteceu na conversa junto às fotos com Dom Vicêncio.

Nos relatos, é possível destacar um padrão, a fim de identificar os modos e a base sobre a qual - ou as quais - se combinam as operações de movimento. As descrições orais descrevem lugares e narram o ritmo da vida das pessoas, representam o corpus cultural do movimento e condicionam aquilo que é percebido. Descrever um movimento exige pensar em caminhos e lugares. Com isto, é possível identificar algumas formas básicas das práticas organizadoras do espaço, como a percepção de um mapa e um trajeto. Estas descrições se fazem na forma de operações que respondem ao formato de vetores, os quais 
podem ser estáticos (por exemplo: na direita, na esquerda) ou móveis (por exemplo, ao dar a volta à direita, dirigindo-se à esquerda). Assim, criam-se narrativas que descrevem itinerários, utilizando operações de movimento e mapas a partir de um assentamento totalizado de observações. Estas formas nas narrativas podem ser encontradas de maneira combinada, criando descrições que oscilam entre os termos do ir e do ver (De Certeau 2000).

Estas duas formas não são excludentes, pois são duas linguagens do espaço, dois polos de experiências que se constituem das estruturas simbólicas e antropológicas daqueles que as usam. $\mathrm{O}$ interlocutor, no momento de narrar uma história, cria cadeias de eventos, sentidos e efeitos e, por sua vez, ordena as referências produzidas pela representação dos lugares e que, consequentemente, implica na descrição da ordem e do lugar. Assim, as pessoas movem-se por entre os significados que reconhecem e recriam, através de indicações e direções que representam as variações sociológicas de cada um (Whitridge 2004).

A descrição dos percursos e dos mapas estão marcados pelos momentos em direção aos lugares. É pela persistência do andar através de caminhos e lugares que estes são reconhecidos e, assim, tornam-se plausíveis de existência e perpetuados na memória. No ato de narrar rememorando o ato de andar descreve-se de forma performática aquilo que deve ser visto e seguido durante o caminho. Para pessoas como Dom Vicêncio, rememorar caminhos implica expor como se deve fazer o caminho.

\section{2 - Trajetos e caminhos}

Esta mesma experiência repetiu-se entre a maioria dos pastores - inclusive crianças - para quem se perguntou sobre caminhos e lugares. Ao mesmo tempo em que o lugar surge na memória, ele é descrito a partir do trajeto que deve ser feito. Porém, à primeira vista, as indicações do trajeto não são facilmente inteligíveis a todos aqueles que os escutam, pois são identificações que fazem parte do simbólico daquelas pessoas. Poder acessar as áreas através dos trajetos que são descritos exige o conhecimento dessa paisagem pastoril, ao mesmo tempo em que o seu desconhecimento - ainda quando os caminhos pareçam estar claramente marcados no chão - impossibilita de seguir as rotas corretas e, consequentemente, de acessar os locais desejados. 
Durante um percurso, as pessoas fazem os caminhos já conhecidos e transitados muitas vezes, mas, a todo momento, os marcadores surgem. Ao mesmo tempo, os caminhos não são lineares, são como repositórios de ações e histórias, percorrem, portanto, essas ações repetidas e histórias contidas, integram, entre os diversos pontos de conexão, caminhos menores. Assim, um caminho longo, como são os caminhos de pastoreio, é construído a partir de vários pequenos caminhos.

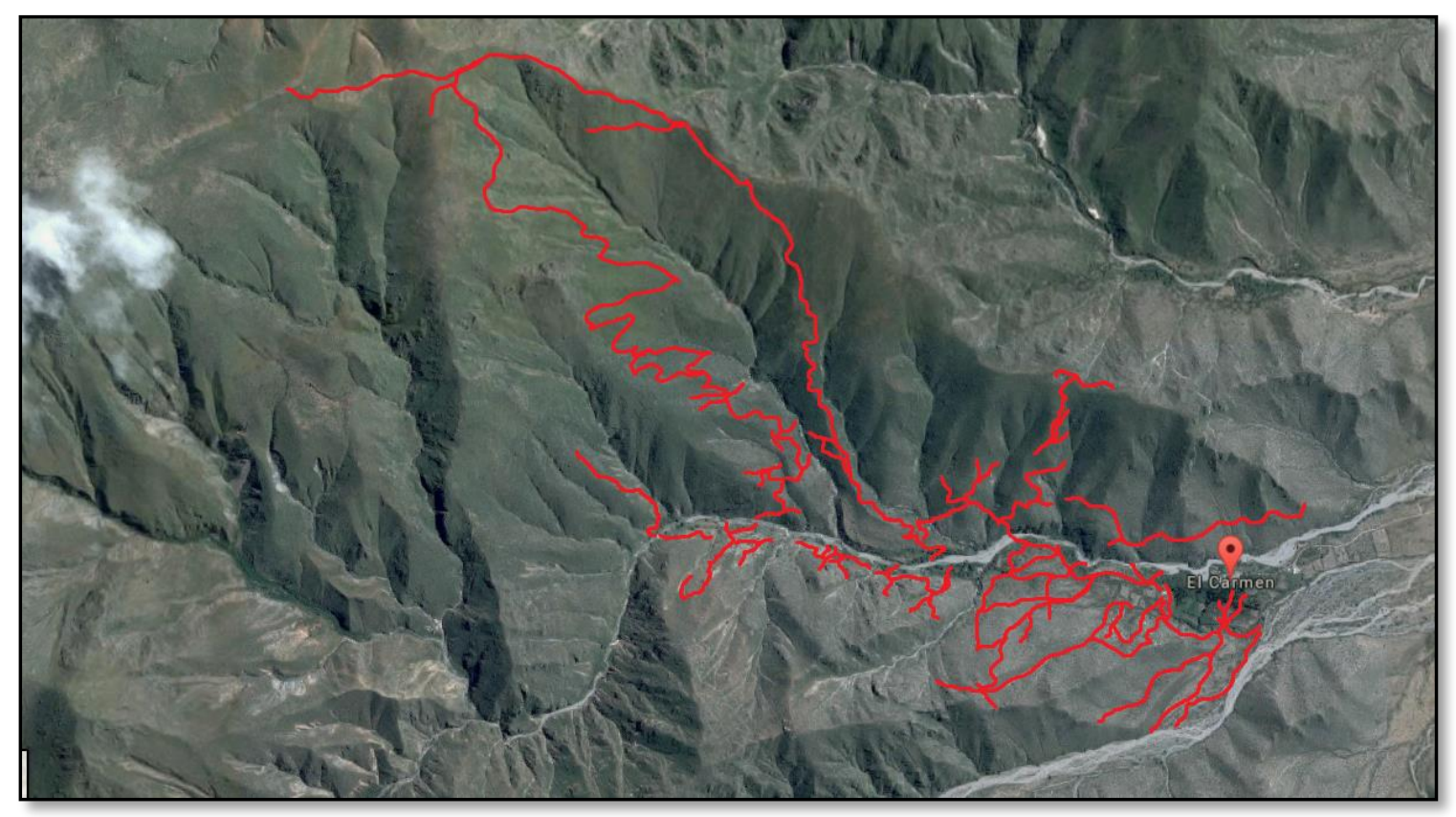

Figura 30 - Imagem ilustrando o mapa com alguns caminhos referente à localidade de El Carmen. Os caminhos são aproximações.

Estes longos caminhos que percorrem toda a encosta da alta montanha ligam diversos caminhos que convergem de diversas direções. Portanto, ao se destacar esses diversos caminhos, encontra-se uma complexa rede que conflui em um mesmo destino final, que são as pastagens mais altas. Porém, separadas cada uma das partes que constituem um grande caminho, descobre-se a diversidade de ações e atividades que esses pequenos caminhos integram a um caminho principal. 


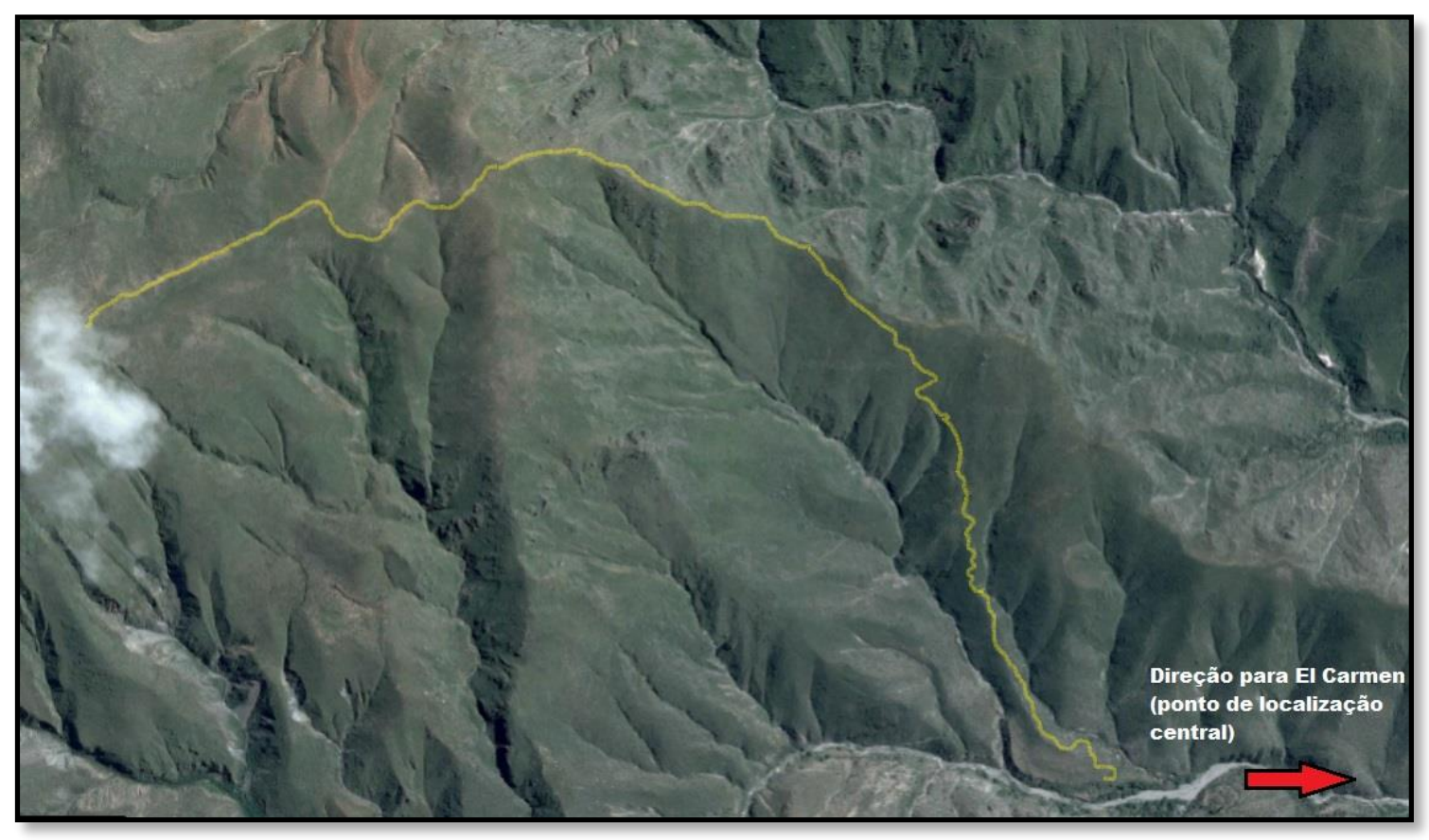

Figura 31 - Imagem ilustrando o mapa ilustrando um dos caminhos em destaque. Referente à localidade de El Carmen.

Essa intensa rede de caminhos é reconhecida e identificada por aqueles que a transitam regularmente. Ao mesmo tempo, esses caminhos também representam um caráter afetivo ou emocional, pois retomam informações que são construídas desde a infância, integrando conhecimento prático às memórias. Para examinar o conteúdo significativo desses caminhos, há que se entender o caráter identitário que eles podem conter. Para fazer este "percurso" pelas informações significativas que um caminho contém há que se aprofundar nas experiências pessoais.

Por isso, destacou-se um único caminho (visível na figura anterior). Este caminho conecta a primeira subida a partir do rio a um caminho de pastoreio. Comparando-se com as figuras anteriores, existem vários caminhos para alcançar o ponto inicial desse caminho específico. Assim, a escolha do percurso atém-se aos trajetos que são habituais à pessoa que o faz, isso quer dizer, que o percurso integra informações práticas (de necessidade do que se busca e facilidade de trajeto) a informações simbólicas (construções e identificações socioculturais construídas). No caso, o local final é um trajeto de pastoreio que chega aos caminhos de altura, porém no caminho encontram-se: locais de plantio (como a presença de diques para manter o rego por mais tempo, mesmo após o fim das chuvas), pastagens de estação chuvosa para os animais, uma fonte de retirada de argila, 
locais de pastagens que permanecem mais tempo férteis, postos temporários para o descanso dos animais e dos homens, acesso aos pastos permanentes das regiões mais altas, além de conectar este pequeno vale a outros.

Como consta no capítulo anterior, as serras são espaços do pastoreio e, consequentemente, dos pastores, portanto quem fazia o trajeto para buscar argila era Dom Yucra, que conta que sua mãe era oleira, por isso sabia de locais onde havia argila que ela considerava boa para fazer panelas e potes. Apesar da mãe deste senhor conhecer o trajeto e saber exatamente onde se encontrava a fonte da matéria prima, era percurso do pastor, portanto era o filho quem ia buscar a matéria prima.

Ao fazer este trajeto, com Dom Yucra, passou pela antiga casa da mãe e daí seguiu pelo caminho. Durante todo o trajeto, Dom Yucra foi indicando o que deveria ser feito e visto para seguir o caminho, destacando pontos importantes. Desta forma encontramos:

a) Pontos de tipos de construções: destacam-se casas de familiares, parentes e conhecidos, presença de porteiras, currais, postos temporários.

b) Pontos de tipo de terreno: destacam-se tipos de caminhos, presença de rochas e/ou pedregulhos, terreno aberto, condição do terreno, íngreme ou plano.

c) Pontos de tipo de vegetação: destaca-se o tipo de vegetação, se são arbustos ou gramíneas, se estão à altura dos olhos ou baixos, permitindo a vista aberta.

d) Pontos de tipos fisiográficos: destaca-se a presença do rio (se deve ser acompanhado ou cruzado), acesso às áreas mais altas, planas ou acidentadas.

e) Pontos de tipos de caminhos: destacam-se os diferentes tipos e aspecto dos caminhos.

No percurso dos caminhos, todos estes pontos encontram-se integrados, indicando para onde o caminhante deve seguir, se deve virar ou seguir, inclusive por onde o caminhante deve encontrar os marcadores.

\section{3 - O caminho de Dom Yucra}


Na localidade de El Carmen, o rio que cruza esta parte das serras tem um leito estreito e "apertado" entre as altas encostas íngremes da serra, por isso nem sempre é possível fazer o trajeto pelo leito do rio. Existem vários caminhos que cruzam as serras deste pequeno vale. São caminhos de pastoreio, o que indica que são transitados com regularidade e cuidado. Segundo é informado, ainda há muitos moradores no interior da serra, diferentemente de locais mais próximos à zona urbana de Santa María, como é Las Mojarras).

O caminho que foi destacado é um percurso conhecido por vários pastores. $\mathrm{Na}$ cima da serra, encontra-se um passo entre montanhas que leva à Puna e que era muito procurado pelos homens para deixar os animais pastando, principalmente quando já não havia pastos nas áreas mais baixas.

O caminho está todo entrecortado por propriedades, porém é possível abrir as porteiras. É comum entre pastores a possibilidade de transitar por caminhos, mesmo quando estes cruzem propriedades de diversas pessoas. Não é somente em Santa María que esta prática se destaca, mas em diversas comunidades pastoris tradicionais. Como os caminhos existem para conectar lugares importantes (como pastagens e lugares com água), tendem a ser de trânsito de todos.

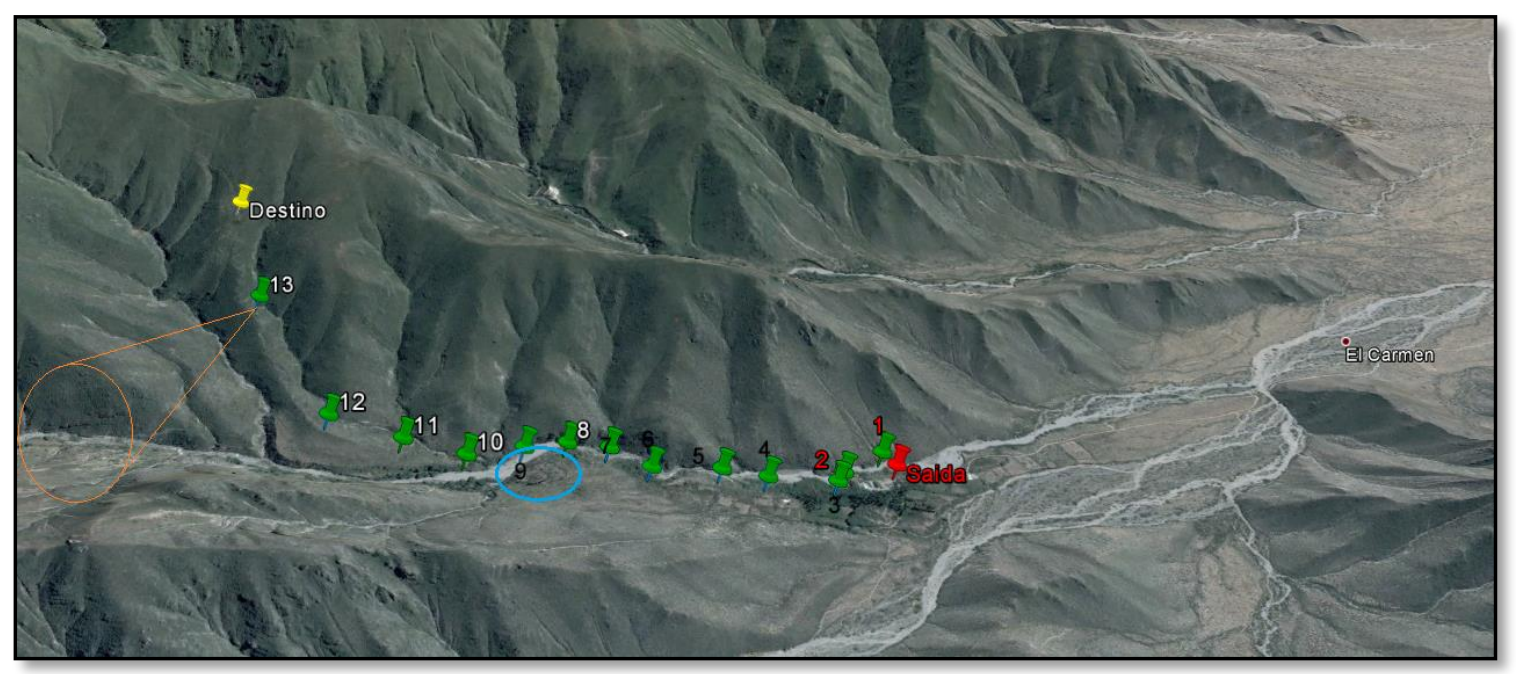

Figura 32 - Imagem ilustrativa do mapa com o caminho percorrido com Dom Yucra. Destacam-se os pontos que marcam esse caminho. 
O caminho teve início na casa onde mora Dom Yucra (indicada no mapa como o ponto da cor vermelha, nomeado como “saída", elevação $2351 \mathrm{~m} \mathrm{~S} 26^{\circ} 34$ ' 19.99 ” O $66^{\circ}$ 06' 55.34”). Desse ponto, Dom Yucra indicou que seria mais fácil seguir pelo caminho do rio (era época de estiagem). Seguimos pelo leito do rio por alguns metros. O caminho parecia aberto e possível de transitar em linha reta, quando o senhor nos indicou para desviarmos para a esquerda e começarmos a subir o barranco para seguir o trajeto que parecia paralelo ao que estávamos caminhando. Nesse ponto, indicou, avistava-se uma grande árvore (indicada no mapa pelo marcador com o número 2), Dom Yucra disse que deveríamos sair do leito do rio e voltar a um caminho por terra. Essa grande árvore foi indicada como sendo a árvore que delimitava o quintal da sua mãe, de quem nos mostrou a casa, e disse que ele fazia esse caminho desde pequeno a pedido da mãe (partindo, portanto, dessa casa e não da casa atual na qual mora). Logo, seguimos por um caminho estreito cheio de vegetação que parecia pouco transitado e que era conectado a outra casa, $d a$ filha deste senhor. Atravessamos o perímetro da casa e ingressamos em um caminho aberto e limpo, cujo início é indicado pelo ponto número 3.

Por esse caminho aberto, caminhamos por alguns minutos, enquanto Dom Yucra mostrava que o trajeto estava correto pois, ao longe, avistava-se a casa de um vizinho. Passamos por uma porteira de casa de outro vizinho e por uma série de pequenos muros de pedras formando grande círculos, ao que ele definiu como currais para manter uma quantidade grande de animais (indicado pela foto) e por alguns currais atuais à esquerda, em tamanho menor. Ambos eram feitos de pirca (pedra sobre pedra) e o segundo apresentava uma porteira feita em madeira de cardón. Estes currais estão localizados, aproximadamente, entre os pontos 4 e 6 indicados na figura do trajeto. 


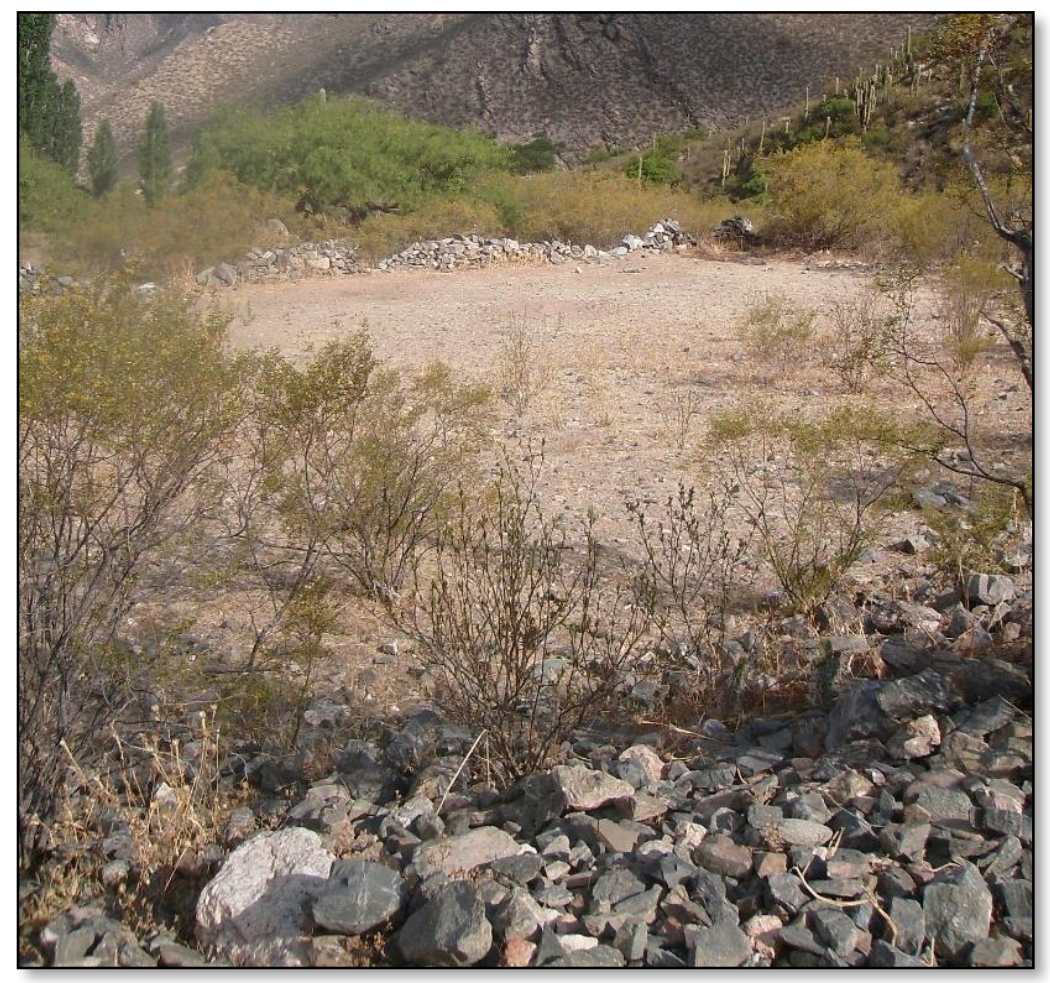

Figura 33 - Foto do grande curral que hoje já não é mais utilizado.

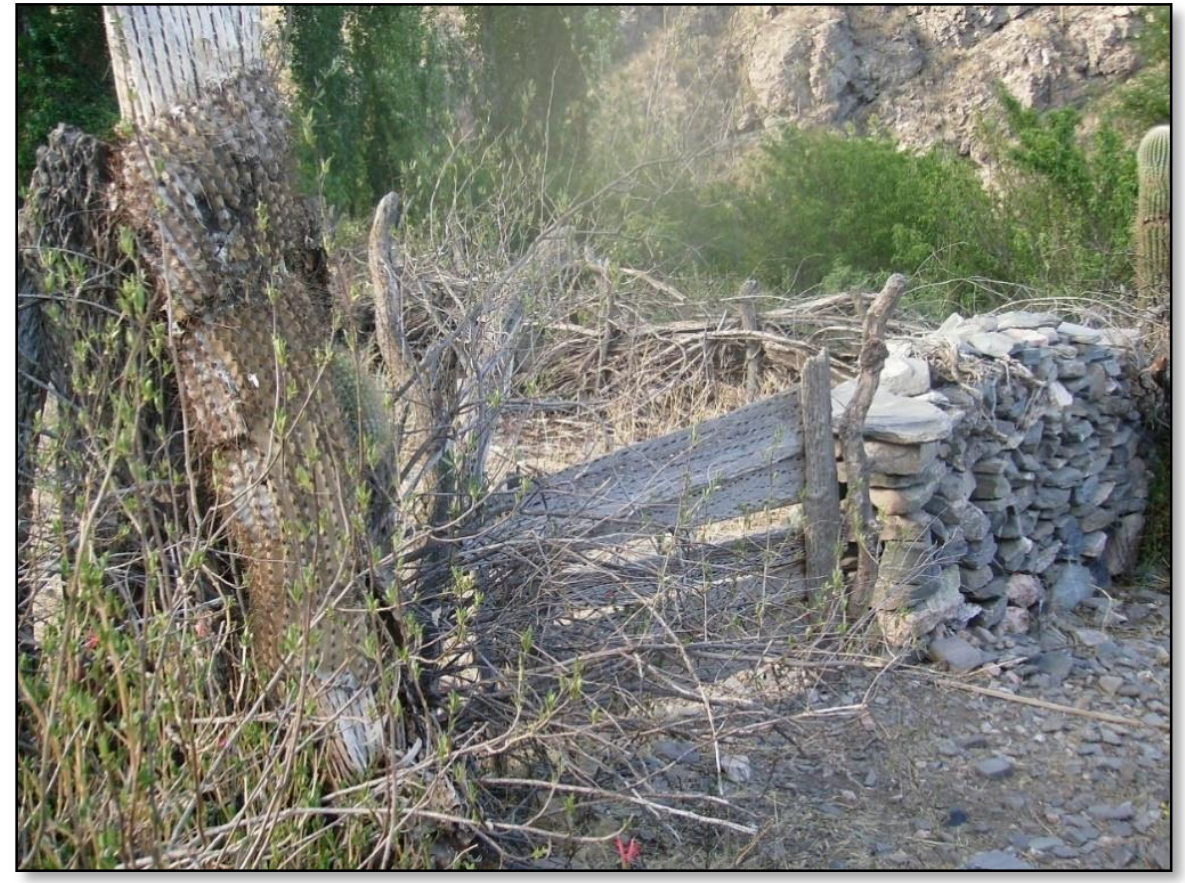

Figura 34 - Foto do curral atualmente utilizado.

A todo momento, Don Yucra indicava, à direita, o local na altura à qual deveríamos chegar. 
Seguimos pelo caminho aberto e limpo até chegarmos a um lugar onde Dom Yucra mostrou, logo à frente, o rio (indicado, no mapa, o lugar aproximado pelo marcador com o número 7), nas margens do rio viam-se pequenos diques em vários lugares (eram diques utilizados para reter a água nos momentos em que o rio não está caudaloso. Esta água é utilizada para regar plantios, para os animais e para limpar os chiqueiros). Nesse momento, o senhor aconselhou a descer ao rio novamente, pois à frente havia uma formação mais alta que dificultava a passagem para chegar (indicada pelo círculo da cor azul).

Caminhamos poucos metros pelo rio (marcadores de número 8), atravessamos o rio (indicado pelo marcador de número 9) e chegamos a uma porteira de madeira (indicada pelo marcador número 10), a qual estava apenas amarrada com uma corda, o que permitiu abri-la e atravessar, acessando-se um campo com vários arbustos que o senhor indica como plantas que os animais podem se alimentar. Muitos ficam ali perto do rio nos períodos mais férteis. Seguimos por outro caminho limpo e bem demarcado. Durante este percurso, era possível notar a presença de estrume de animais no solo. $\mathrm{O}$ caminho tornou-se um pouco mais íngreme indicando que se estava subindo a serra (este caminho está indicado pelo marcador número 11). Seguimos a encosta da serra. Depois de uma certa altura, o solo começou a ficar rochoso e a vegetação diferente. Depois de alguns minutos por esse caminho mais pedregoso, Dom Yucra para em um lugar de descanso, indicado por uma formação de pedras em um espaço pequeno sem vegetação, só com terra. Esta parada, segundo o senhor é apenas para os humanos (é um espaço reduzido, pois é para poucas pessoas), os animais não param. A formação de pedra apresenta vários desgastes. Para Dom Yucra, essas marcas indicam que outras pessoas sentaram e sentam-se ali constantemente ${ }^{23}$.

\footnotetext{
${ }^{23}$ Infelizmente, em alguns momentos do trabalho de campo não é possível parar para tirar uma fotografia.
} 


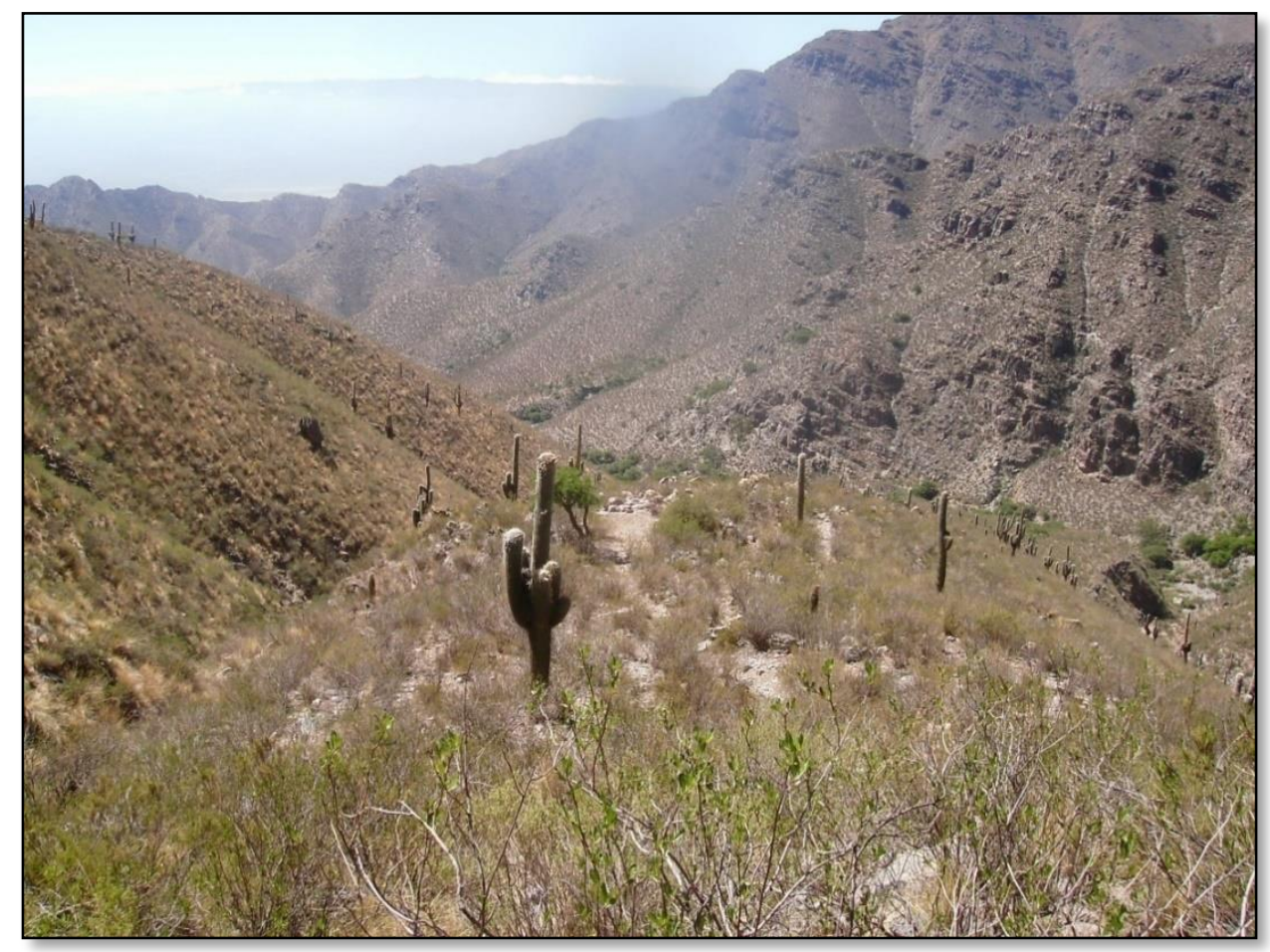

Figura 35 - Imagem indicando o primeiro local de parada pelas pedras amontoadas ao fundo, com vista do caminho.

A partir dessa formação rochosa, a subida torna-se ainda mais íngreme, o terreno começa a ficar mais pedregoso e apresentando rochas soltas. Em alguns momentos, as rochas do solo foram posicionadas de forma a constituir degraus para facilitar a subida. Depois de alguns minutos de subida, fica perceptível que a vegetação muda abruptamente, as gramíneas com espinhos dão lugar a uma formação de arbusto e logo abre-se um espaço plano na encosta da montanha, formando uma espécie de clareira, na qual é possível observar uma espécie de construção de andaime de contenção nas bordas no chão. $\mathrm{O}$ estrume e a areia solta e sem pedras destaca as marcas de animais que passaram há pouco tempo por ali. Em uma das partes, cresce uma árvore que não é comum nessa altura nas montanhas. Do outro lado da árvore, afloram grandes pedras que servem como parede e parapeito, como resguardo do tempo. É local seguro para se sentar. Desta local, pode-se ver o caminho do rio e as subidas das serras, logo a frente. Do outro lado do rio, vê-se uma pequena casa de campo e um curral (indicado na figura pelo círculo de cor alaranjada).

A partir deste local de parada (ou posto temporário), segue-se um caminho reto até grandes rochas brancas que se destacam na vegetação. Esse local é indicado por Dom 
Yucra como sendo o lugar onde há argila. A partir desse posto temporário, as rochas dos caminhos começam a estar mais firmes e são maiores formando o que parece uma escada íngreme de difícil subida.

Na subida, existem várias rochas brancas e grandes como aquelas que Dom Yucra havia indicado como sendo o local onde havia argila, porém não são as indicadas. A diferença na formação e composição de rochas, solo e vegetação é percebida por estas pessoas, pois ao se realizar tantas vezes um mesmo trajeto, os elementos nele contido começam a ser percebidos nas suas várias características, criando familiaridade e, consequentemente, distinção. Por sua vez, os caminhos também passam a ser reconhecidos na sua totalidade, sendo que é perceptível ao caminhante assíduo o que constitui verdadeiramente o caminho e o que está fora do perímetro dele.

Logo depois de se passar pelo local da argila, o caminho fica mais íngreme e difícil de transitar. Porém, a poucos metros desse local chega-se ao destino que é uma área aberta e plana, relativamente grande, a qual contém um grande curral (indicado no mapa como o ponto da cor amarela nomeado “destino", com elevação $2745 \mathrm{~m} \mathrm{~S} 26^{\circ} 33$ ' 51.91 ” O $66^{\circ}$ 07' 49.78”). O curral está em uma pampa de altura, com acesso fácil para os animais a uma vegetação que permanece fértil por um período maior que a do vale. Este curral incorpora-se também ao caminho que leva àqueles caminhos de pastoreio de altura que existem nestas serras, portanto é curral muito utilizado. 


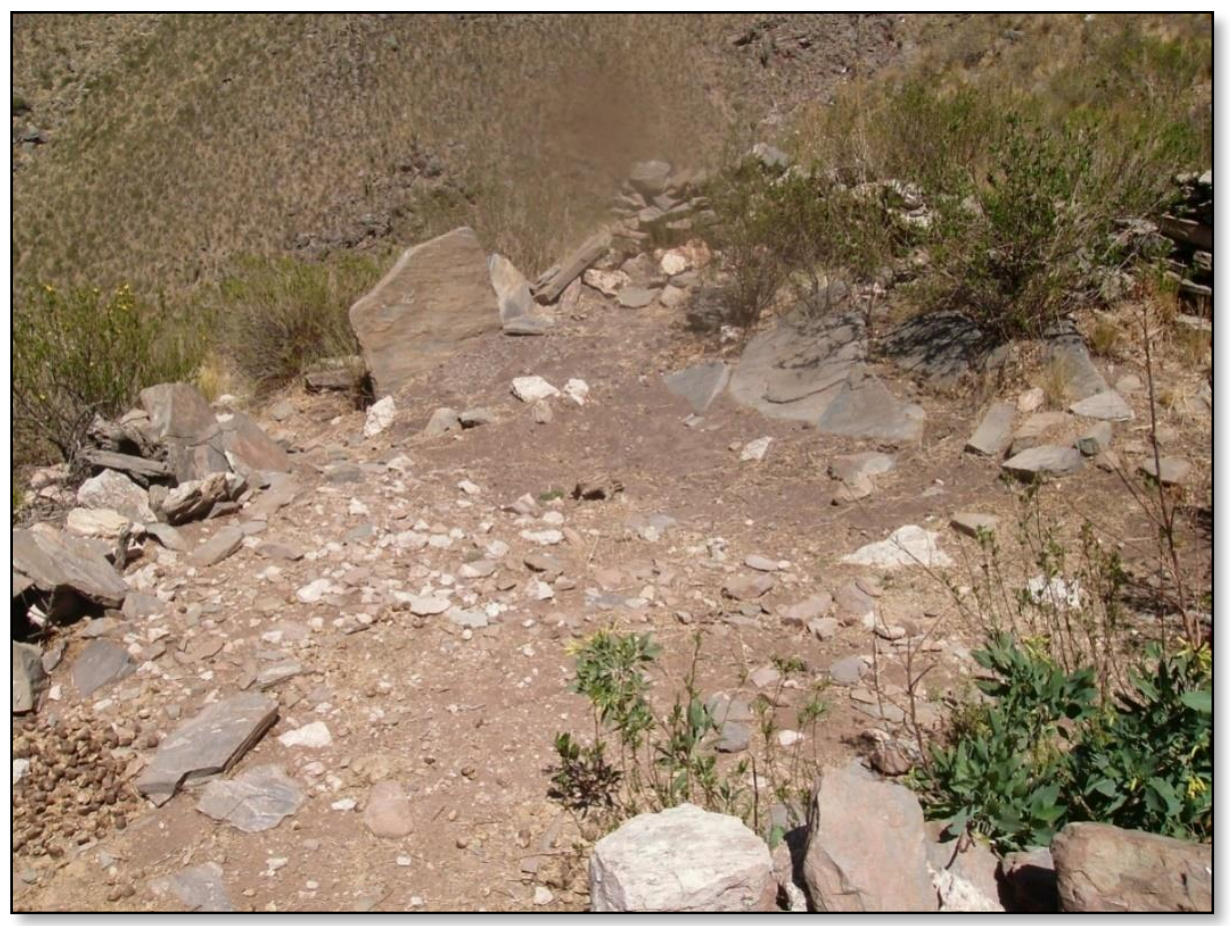

Figura 36 - Imagem indicando as lascas e pequenos muros de pirca. Sobre o contorno na serra formando uma área plana (espécie de andaime), no qual os animais se acomodam. A imagem destaca também a presença de plantas comestíveis para os animais diferentes das demais do alto da serra.

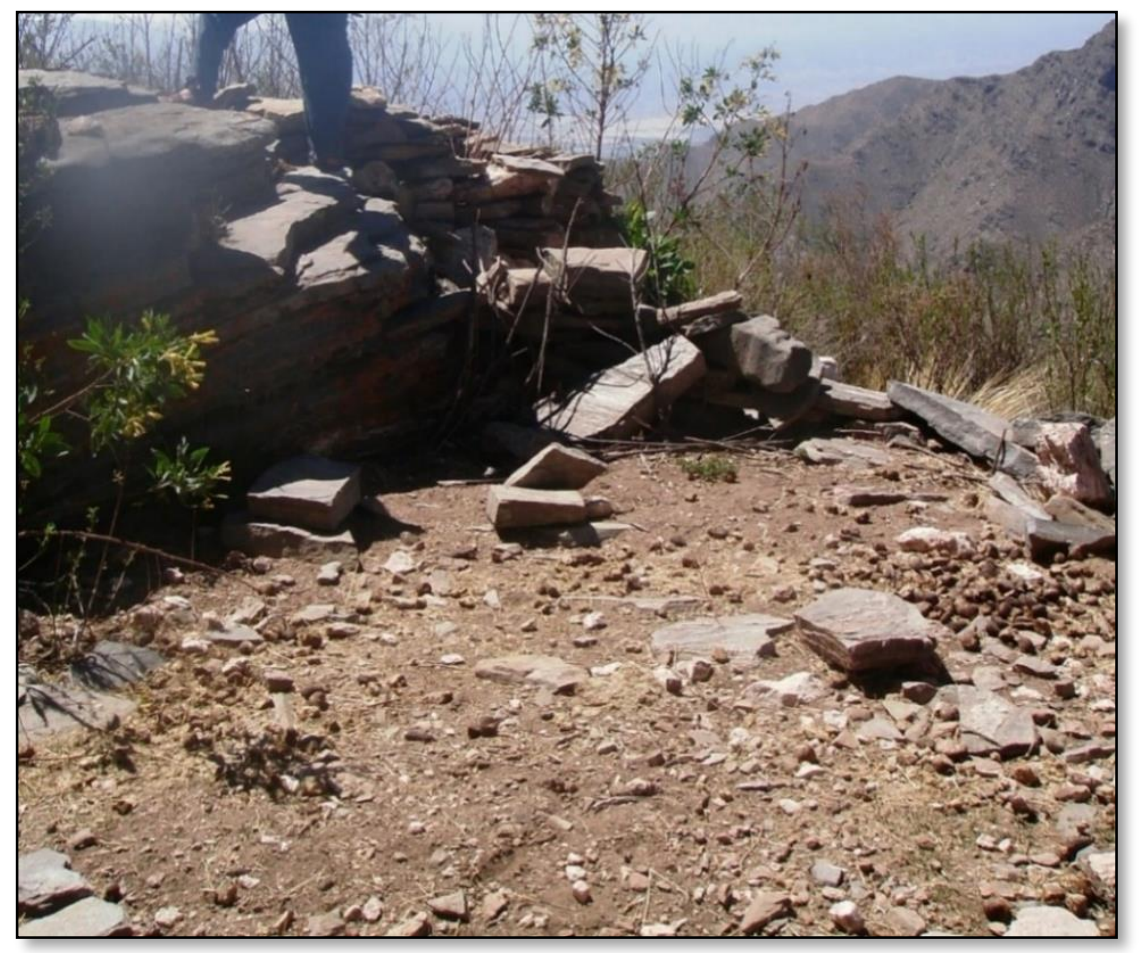

Figura 37 - Imagem indicando o curral no alto da serra, construído com materiais rochosos da redondeza. Destaca-se também uma parte mais alta construída, que serve como resguardo dos animais e provavelmente do pastor. 
Há alguns metros seguindo por essa mesma rota, acessam-se os caminhos mais altos que levam à Puna, indicados pela figura a seguir:

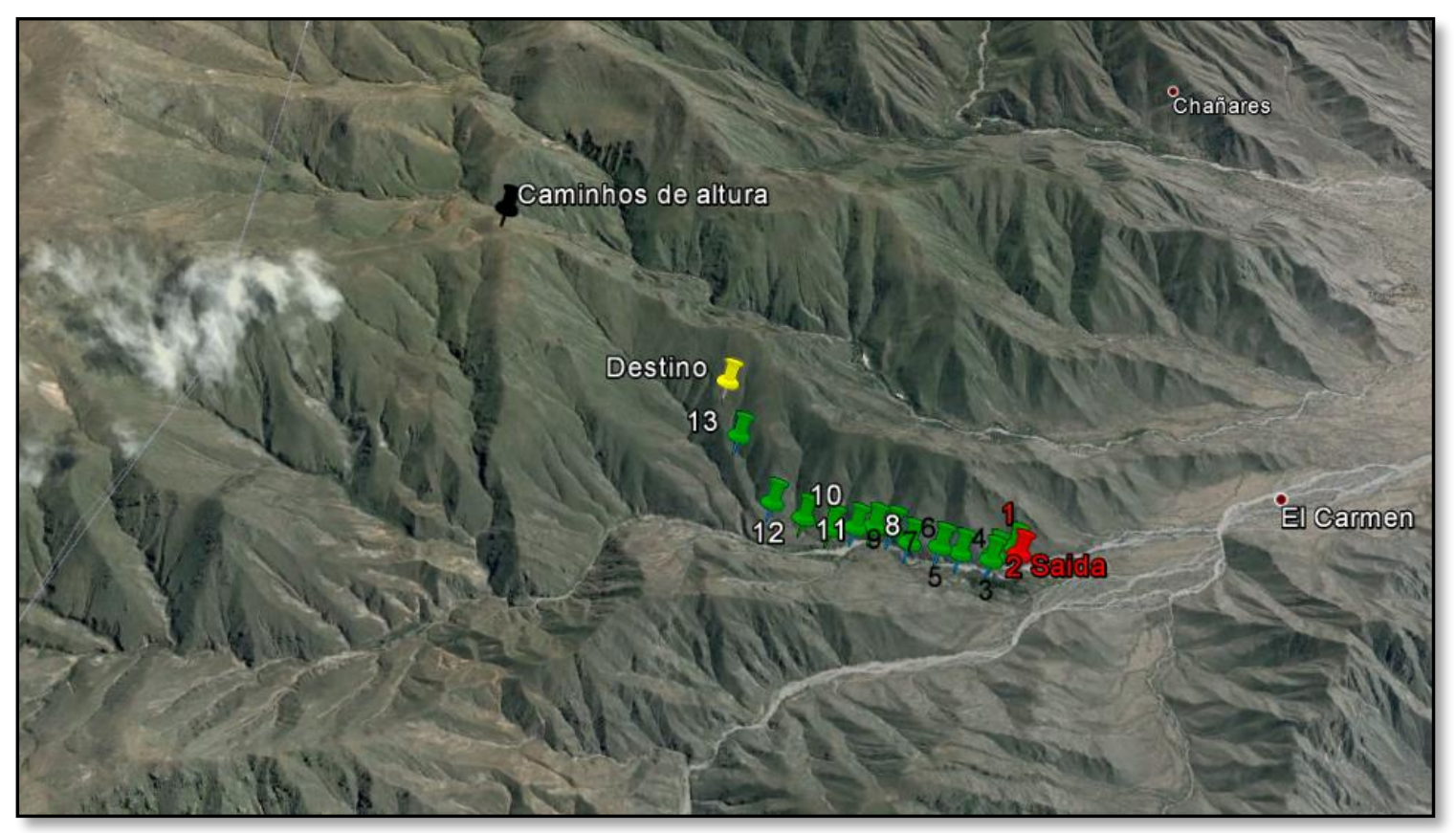

Figura 38 - Imagem indicando os pontos do percurso de Dom Yucra. Um ponto do caminho em altura em cor preta, coordenadas: elevação $3304 \mathrm{~m} \mathrm{~S} 26^{\circ} 33^{\prime} 26.57^{\prime \prime} \mathrm{O} 66^{\circ} 08^{\prime} 32.14^{\prime \prime}$.

Durante todo o percurso do caminho, Dom Yucra manteve passos constantes, com as mãos cruzadas nas costas, mantendo a coluna sempre reta. Na subida ou na descida, manteve sempre a mesma postura e o mesmo ritmo de passadas. Durante todo o caminho, ele contava e indicava as casas e os currais, a quem pertenciam e como chegar a cada um. O caminho para este senhor faz parte da sua história de vida, cada elemento presente na paisagem era um marco que integrava a história dessa paisagem à história de vida dele. 


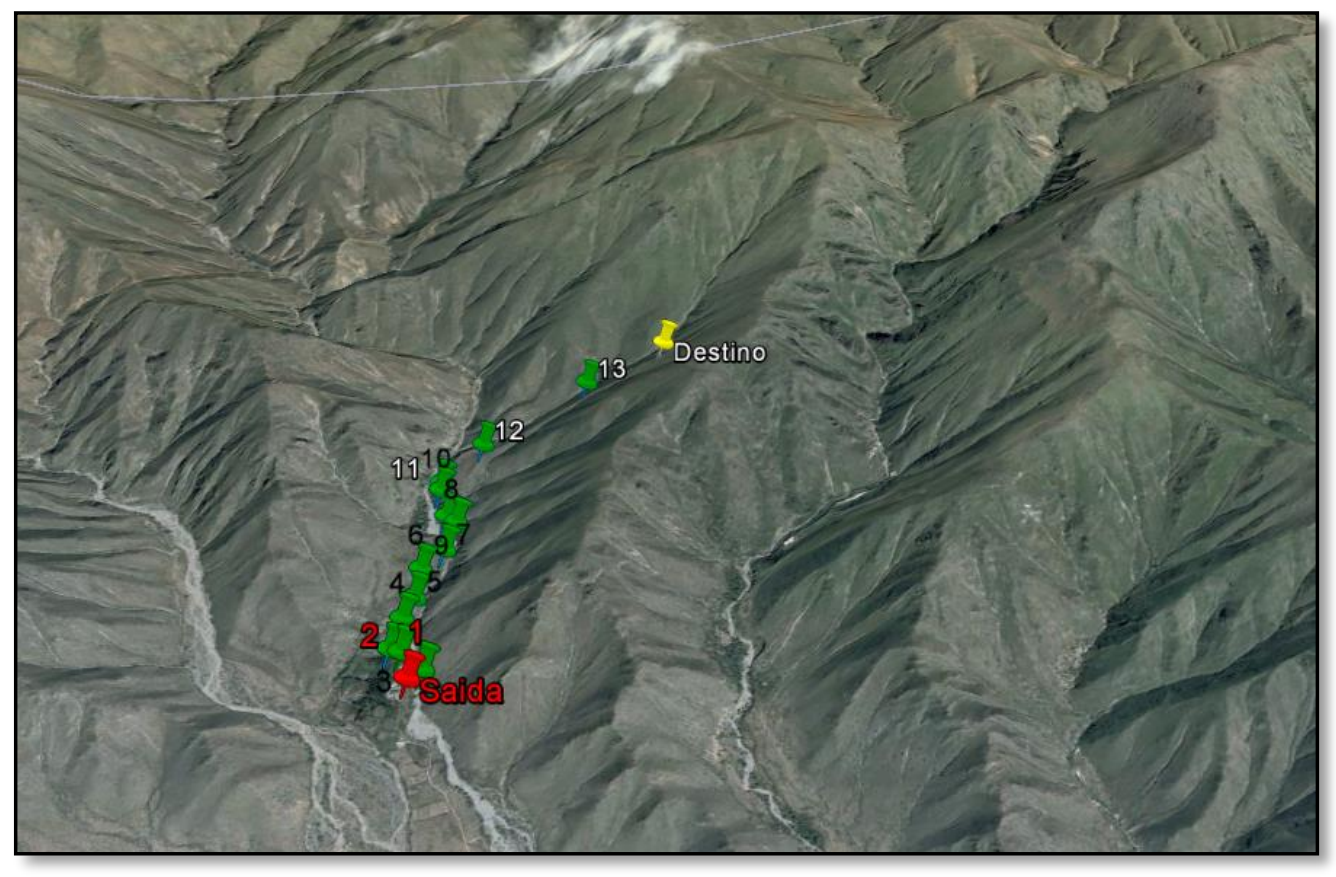

Figura 39 - Representando o trajeto feito com Dom Yucra desde uma vista E-O. Indicando a saída pelo marcador da cor vermelha e a chegada pelo marcador na cor amarela.

A pesar de que, enquanto se fazia o trajeto, a impressão era que se estava dando mais voltas do que o necessário, quando colocado o trajeto em outra perspectiva no mapa, percebe-se que o caminho feito com Dom Yucra é relativamente direto, somente foram seguidos marcadores de paisagem importantes para se seguir uma linha em direção ao destino, porém não se fez desvios ou trajetos mais longos.

\section{4 - Sobre caminhos e marcadores de caminhos}

As paisagens que estes pastores descrevem são, indiscutivelmente, paisagens do movimento, pautadas por dois conceitos:

1- O caminho, que se refere às propriedades físicas e culturais presentes nas rotas.

2- A rota, que se refere à direção, ao modo de se movimentar e à distância do movimento.

Quanto aos caminhos, eles são de extrema importância na vida pastoril. Os caminhos são o processo do acontecer e representam o movimento e o habitar dos lugares. No cotidiano das pessoas do lugar, os caminhos não são todos iguais, sendo indicados 
pelo tipo do terreno, pela presença de alguns elementos específicos e pelas vivendas que o constituíam.

O tipo de terreno implica no estado e nas características do próprio caminho. Cada um apresenta uma característica e o grau de dificuldade de seu percurso, portanto, utilizase uma série de designações para reconhecer o tipo de caminhos.

Os caminhos podem ser designados como "caminho lindo", por exemplo, que indica a existência de uma estrada e calçamento. Estes caminhos são fáceis de transitar, estando sempre limpos e livres para a passagem. São caminhos largos pelos quais podem passar carros, cavalos, bicicletas, pessoas etc. As estradas ou ruas - que não sejam as da cidade e as vias principais - são designadas como caminho lindo.

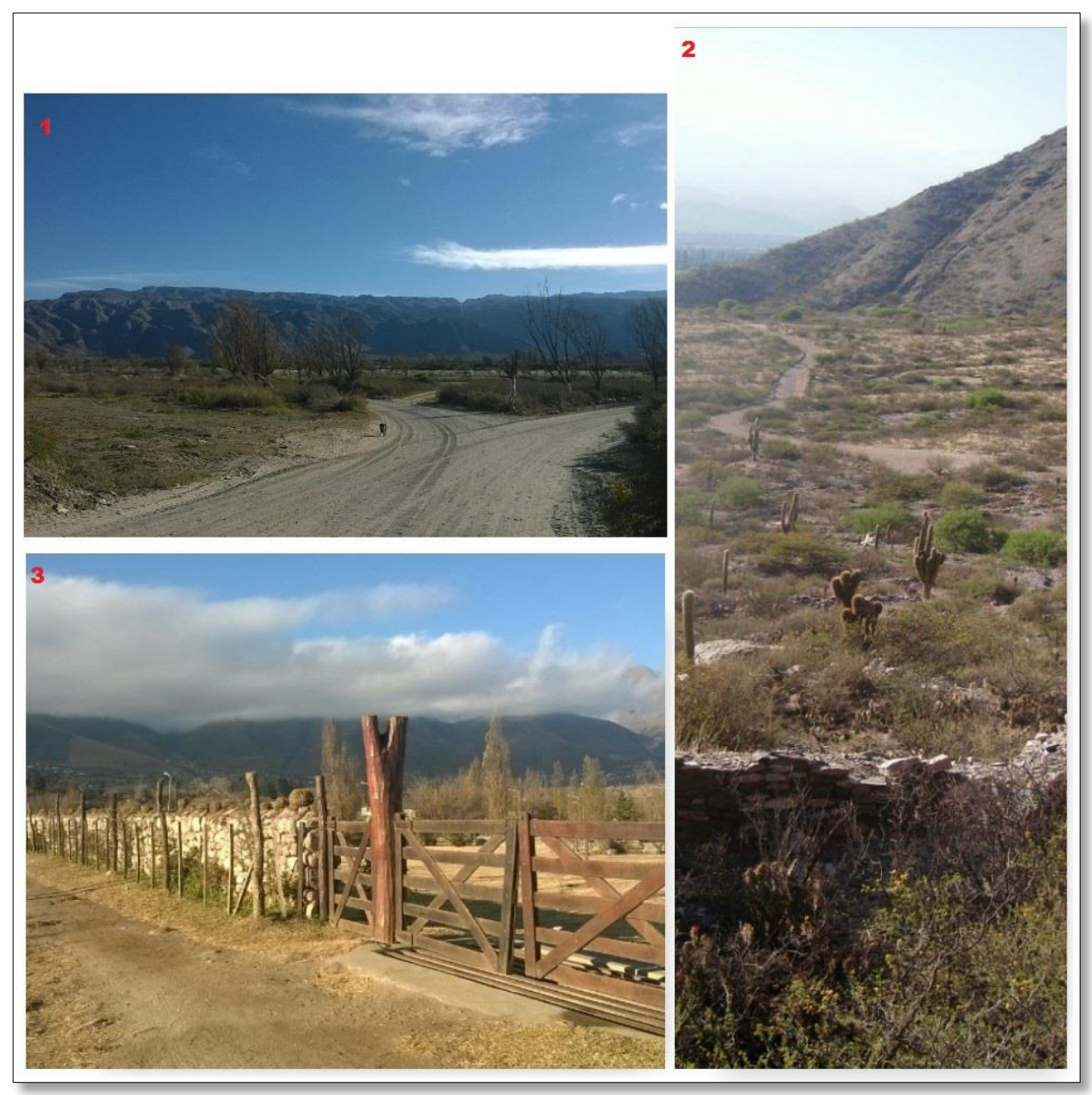

Figura 40 - Fotos representando 3 tipos de caminhos que podem ser designados como "caminho lindo". 
Quando o caminho passa a ser estreito, deixa de ser designado como caminho lindo e, mesmo o seu trajeto estando limpo, a presença de vegetação e o diâmetro definem outro tipo. Este tipo de caminho é fácil de seguir, pois todo o seu percurso é visível. Estes caminhos podem atravessar fazendas e adentrar os espaços de serra. Nas, serras, também há os caminhos com maior dificuldade. Ainda que visíveis, são constituídos por pedras no chão e dependendo da ingremidade do terreno, as pedras podem estar posicionadas formando uma espécie de degraus para facilitar a subida. Há outro tipo de caminho pelas serras, que são aqueles que conectam um pequeno vale a outro. Também existem os caminhos dos animais. Os caminhos dos burros são fáceis de seguir, porém os caminhos das cabras são muito difíceis. Indica-se sempre um caminho paralelo quando há um caminho de cabras. Por fim, existe o caminho da água, que pode indicar o caminho que se faz por dentro do caule seco da passagem de água ou aqueles sulcos que a água faz no solo da serra. Este caminho diferencia-se do caminho do rio, que se apresenta como outro tipo.

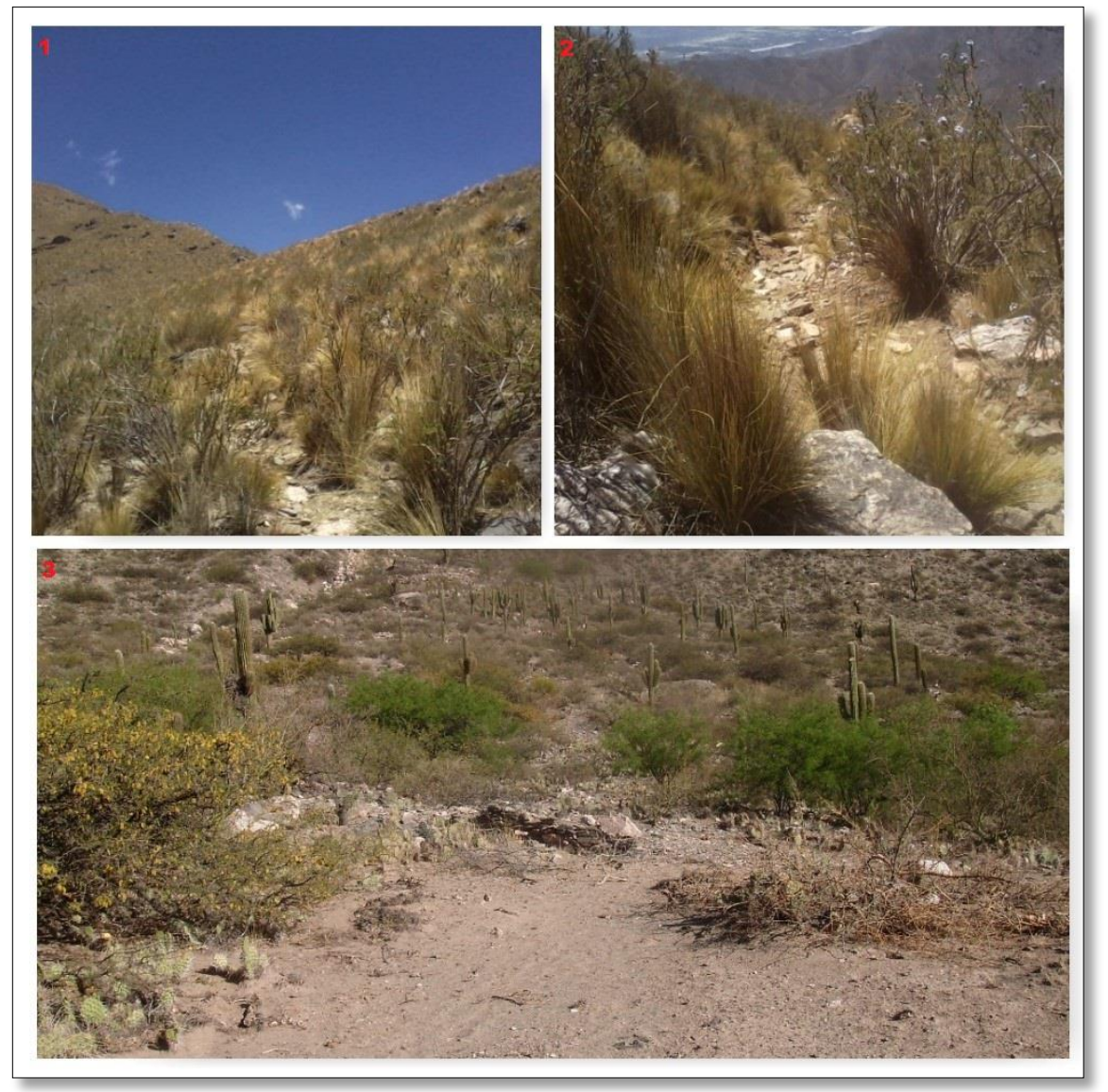

Figura 41 - Fotos representando os tipos de caminhos das serras. 1- Representa um caminho de cabra ao lado do caminho de homens. 2- Representa um caminho com o trajeto demarcado com rochas posicionadas para formar degraus. 3- Representa um caminho aberto entre a vegetação. 


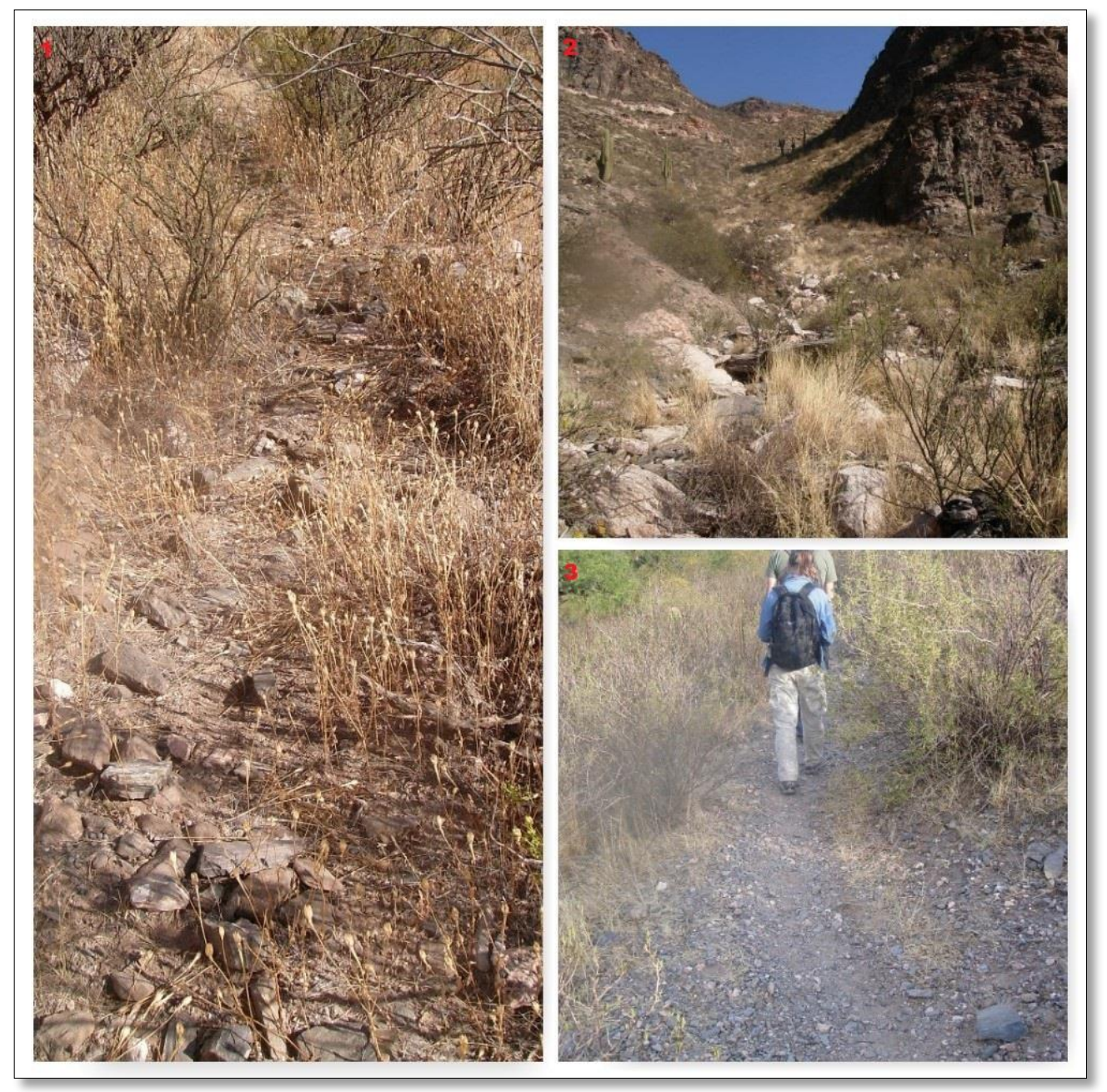

Figura 42 - Fotos representando tipos de caminho. 1-Representa um caminho com o trajeto demarcado com rochas. 2- Representa um caminho de água. 3- Representa um caminho aberto (não designado como caminho lindo).

Alguns destes caminhos, como os caminhos das cabras e o caminho das águas, que não são transitáveis, são indicadores de onde se encontra o caminho que deve ser seguido. Também existem outros indicadores de caminhos, sendo que, muitas vezes, o próprio caminho é utilizado como marcado, indicando que se deve seguir por um caminho que apresente determinado aspecto. Dentre outros elementos presentes nos caminhos que também são marcadores, destacam-se: currais, porteiras, cercados, formações rochosas ou fisiográficas do terreno, casas ou propriedade de pessoas etc. Estes marcadores, além de indicar por onde a pessoa deve seguir, eles também ditam como as pessoas devem se 
comportar durante o trajeto, indicando para onde se deve seguir, por exemplo visualizando uma casa à direita, ou ainda tendo à vista sempre uma formação rochosa à frente. Além disso, também marcam o ritmo, indicando quanto se deve caminhar até determinado ponto que seria a parada. No contexto, nem todos os indicadores necessitam estar sobre o caminho em si, podem aparecer à vista ao longe.

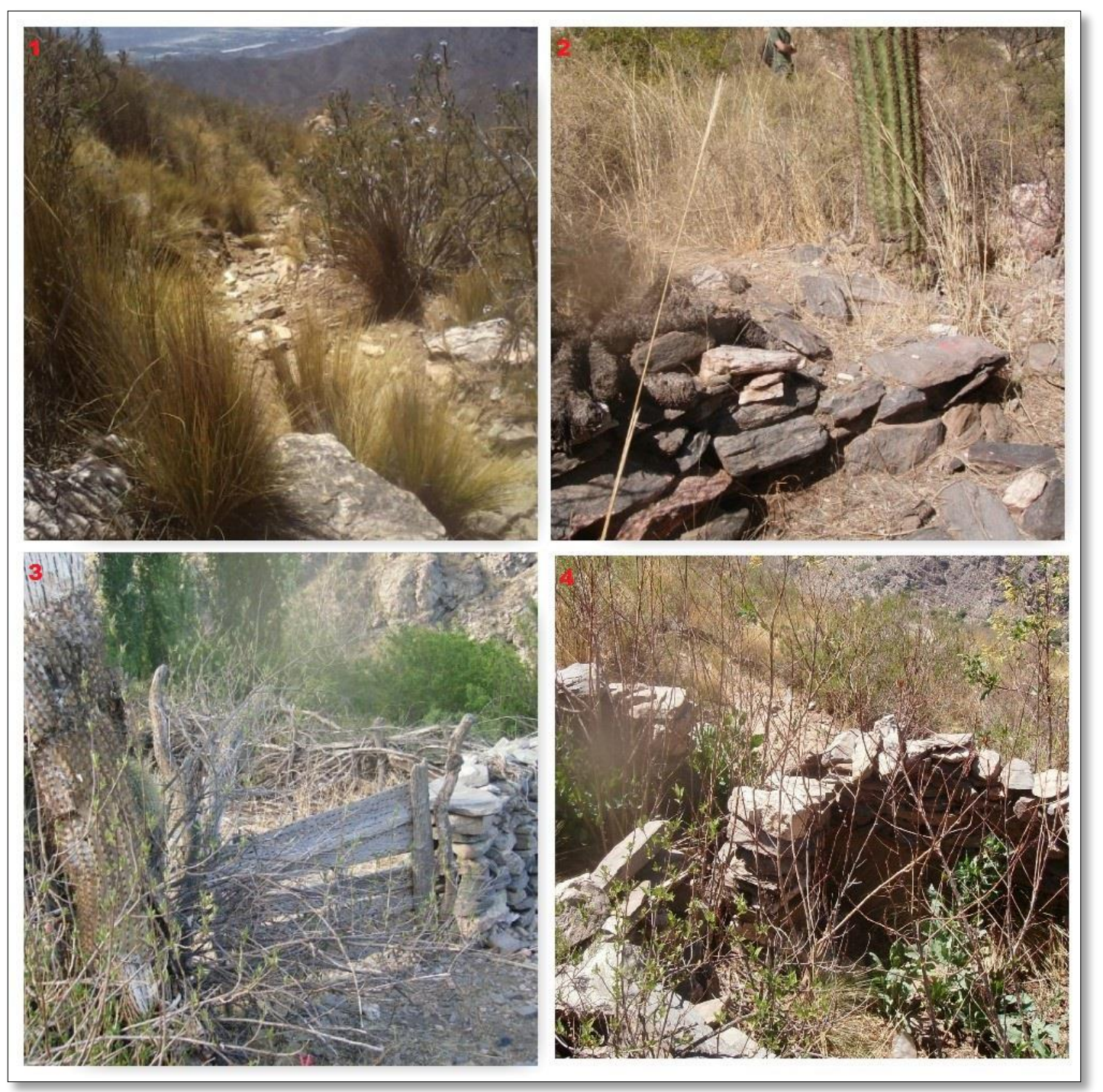

Figura 43 - Fotos representando marcadores de caminhos. 1- Representa a formação do próprio caminho como marcador (a existência de rochas e/ou degraus). 2- Representa uma formação como marcador. 3- Representa uma porteira como marcador. 4- Representa a presença de uma construção como marcador.

Desta forma, no percurso dos caminhos, o caminhante retoma e direciona o conhecimento do lugar, permitindo acessá-lo e rememorá-lo, alcançando uma descrição detalhada em qualquer nível dessas escalas. Assim, Dom Vicêncio, apenas sendo 
informado de como eram as pedras que apareciam nas fotos, já conseguia perceber de onde se estava falando e por onde deveria percorrer para alcançar tal lugar. Assim, fazia uma retomada do local e das histórias que estavam relacionadas a esse local, porém - o que era extremamente confuso para nós - as histórias não necessariamente respondiam àquele lugar específico, mas aos momentos em que ele foi até aquele lugar, portanto eram histórias sobre a jornada, sobre os lugares diversos que levaram à memória daquele lugar específico.

Outra questão fundamental da relação de caminhar pela paisagem é a variação sazonal que exige comportamentos distintos de acordo com os meses de chuva ou estiagem. Na época de chuva, os rios e algumas áreas não podem ser cruzados, por isso os caminhos são outros. Isso reitera, uma vez mais, o que foi colocado no capítulo anterior sobre a distinção dos movimentos de inverno e verão e as zonas dos vales e serras que eles atingem. Assim, toda mobilidade nestes vales andinos é pautada pelas diferentes características de cada estação, a qual implica em: movimentos diferenciados; caminhos diferentes e, inclusive, diferenças nos tipos de construções. Ao mesmo tempo em que estes movimentos têm relação estreita com os períodos do ano e com a oferta de pastagens novas, distintas zonas do ambiente de serras de Santa María também estão produzindo lugares e caminhos, zonas habitadas de paisagens construídas.

A diferença fundamental entre inverno e verão é a quantidade de chuvas. No verão, as chuvas são mais abundantes, por isso existem pastagens férteis ao longo da parte mais baixa do vale e os rios estão caudalosos. Já o inverno é a época da estiagem, momento em que os vales ficam vazios de pastagens férteis e água. As diferenças de movimento e caminho, nesses dois momentos, é clara e não atinge unicamente o movimento dos pastores, também implica em outras dinâmicas do dia-a-dia de toda a população.

Por exemplo, para chegar a Las Mojarras, desde o centro, há que se cruzar o rio Santa María. No período das chuvas e desgelo, o rio está caudaloso, portanto o cruzamento ocorre pela ponte principal, necessariamente. Já, durante o período de estiagem, os moradores locais fazem um caminho mais curto, que economiza até 30 minutos do trajeto. Corta-se caminho por meio do caule seco do rio, atingindo-se uma rua secundária que, segundo os moradores locais, servia em grande medida para levar os animais para as pastagens férteis da beira do rio, no verão. 


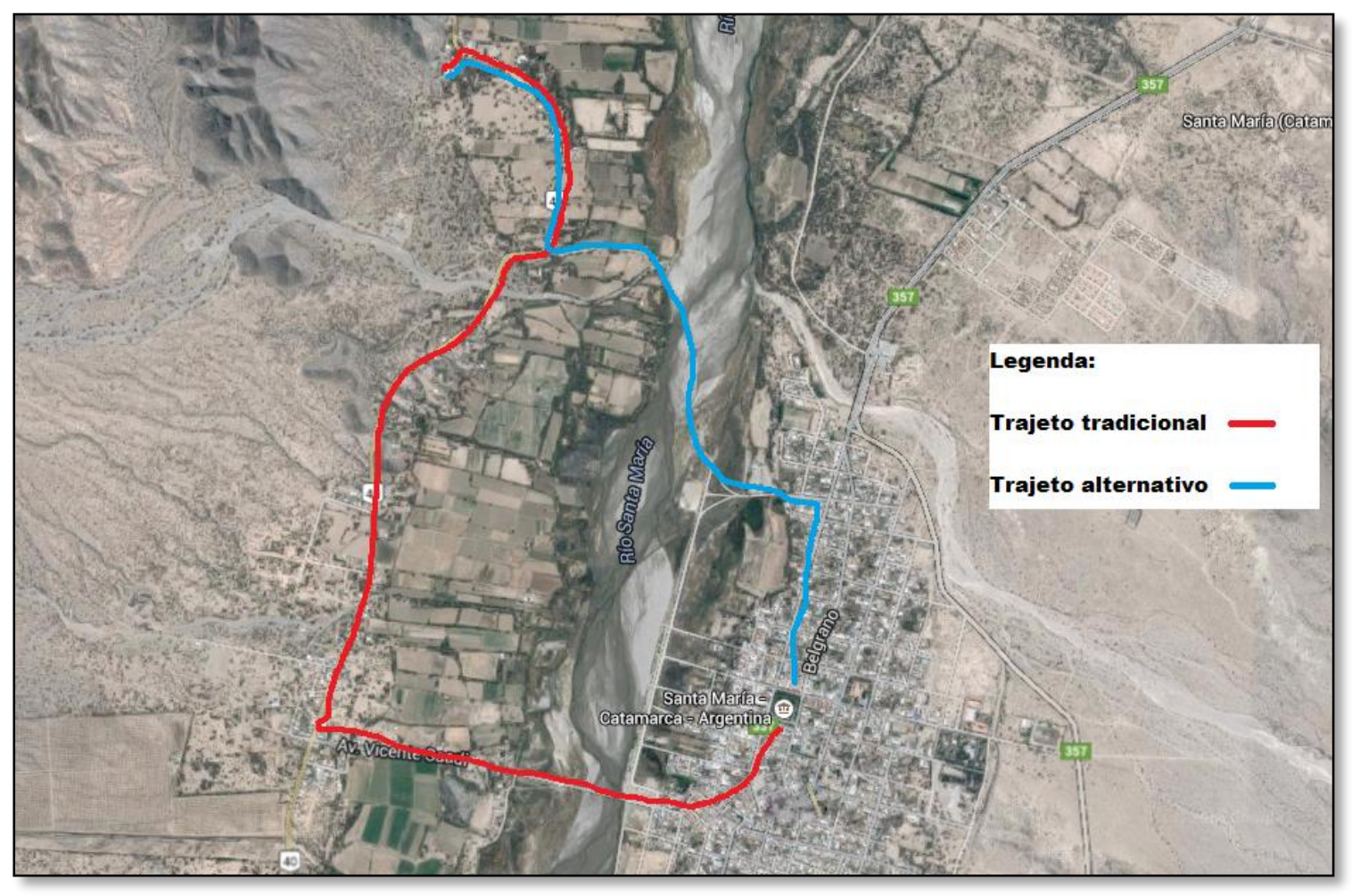

Figura 44 - Mapa indicando os trajetos para cruzar o rio Santa María.

Quanto às construções, também há diferenças que, consequentemente, são implicadas pelas diferenças nos movimentos sazonais. As casas residenciais estão próximas aos locais de pastagem perenes, porém também mais próximas aos mercados e, inclusive, aos materiais necessários para serem construídas. Por isso, são construções maiores com a presença de áreas separadas por divisões internas, que permitem abrigar toda a família. Já os movimentos de inverno, no interior das serras, implicam em construções menores e mais simples. Os postos temporários que existem atualmente são utilizados para guardar coisas ou para o descanso, não abrigam pessoas, por isso apresentam uma construção pequena e simples, utilizando os materiais encontrados nas proximidades.

Desta forma, mover-se implica em adaptar e, consequentemente, em habitar, que também é construir. Constroem-se caminhos e lugares que ditam ritmos e informações específicas sobre o modo como as pessoas estão apreendendo aquela paisagem. No interior das serras, existem várias construções - como currais, locais de parada, caminhos, 
postos temporários etc. -, as quais são marcos de identidade, da forma que um grupo encontrou de habitar e de apreender uma paisagem como própria.

Assim, caminhos e trilhas não são simples vias, são um integrado de necessidades, propriedades físicas e culturais, além de repositórios de histórias e narrativas. Assim, os caminhos têm função, eles conectam lugares e permitem às pessoas acessarem certos locais, por isso podem ser definidos apresentando: a) uma função real, b) uma função prática e c) uma função simbólica.

A função real representa tudo aquilo que faz parte do universo das necessidades que o determinado caminho implica. Logo, alguns caminhos servem para levar a locais de água e pastagens, à casa, à cidade etc. Em outras palavras, a função real representaria o destino final que representa o caminho em si, porém, no percurso dos trajetos, surgem outras funções que podem ser consideradas como funções práticas. Assim, no trajeto em direção a um local de pastagem, pode-se passar pela casa de algum vizinho, ou ainda por uma fonte de argila para a cerâmica, pode-se encontrar determinada matéria prima necessária, arrumar algumas partes do caminho (como corte de vegetação, colocação ou recolocação de rochas etc.) e várias outras funções que acompanham o trajeto sem fazer que o caminhante saia da rota original. É possível inferir que os caminhos também estão respondendo a uma maior acessibilidade aos recursos existentes, combinando as atividades no percurso de acordo com o proposto por Binford (1991). Ao mesmo tempo, é esperado um certo grau de correspondência na distribuição dos recursos e vias de acesso (Schiffer 187), já vez que os elementos presentes na paisagem integram os recursos da terra às intenções e necessidades das pessoas.

Juntamente, todo o conhecimento destes caminhos e trajetos também leva a outra questão que é a função simbólica que representam. Seguir um caminho não é apenas movimentar-se, é reter o trajeto na memória, pois o movimento torna-se realmente efetivo quando se torna familiar. Ao planejar uma jornada, o viajante considera as diferentes rotas, as suas características e os caminhos de acordo à performance exigida, considerando-se as diversas características de recursos naturais, facilidades de acesso, maior segurança e as relações extranaturais (Zedeño et al 2009). Isto se alcança com o conhecimento daquela paisagem, assim, através do movimento por um caminho de pastoreio, conhece-se uma jazida de argila melhor do que aquelas que estão mais acessíveis nos vales. 
Desta forma, caminhar também apresenta uma função simbólica de apreensão daquela paisagem como deve ser vista, a partir dos elementos culturais que ela implica. Nas jornadas, aplica-se uma perspectiva multidimensional para apreender a paisagem, pois o movimento dá conexão a lugares, viagens, memórias e identidades. Assim, as marcas na paisagem são como as páginas de uma história que marcam eventos singulares, as quais servem como indicações cartográficas e ajudam a retomar eventos particulares. Don Yucra levou-nos até a casa onde ele cresceu e fez o caminho que fazia desde criança para ir buscar argila para a sua mãe. A casa da mãe é um marco cartográfico de localização, de partida para a serra e de indicações de caminhos. A partir daquela casa, ele identifica todas as redes de lugares que resgata na memória, primeiramente em uma escala mais distante, percebendo toda a região e as redes de conexões existentes. Acredito que isso se faz da mesma forma como um de nós olharia um mapa e reconheceria os pontos que marcam lugares e as rotas que os conectam em uma cidade através das suas ruas, vias de acesso e de transporte público. Imediatamente, Don Yucra acessa escalas mais micro, onde rememora histórias familiares e as imagens que são retomadas a partir de outros trajetos que já tinha feito.

São essas escalas de resgate de memória a partir de coisas e lugares que fazem que as pessoas se lembrem das jornadas. Fazer uma jornada implica diretamente na habilidade de cada pessoa ler a paisagem. Na memória, tomam-se notas mentais dos trajetos, do que se vê e do que é conhecido. Utilizam-se trilhas de animais, vegetação, topografia, indicadores potencias, presença ou ausência de água etc. Inclusive as crianças são capazes de reconhecer as direções, sabendo que devem chegar até tal pedra, onde se vê tal indicador. São utilizadas expressões como caminhos lindo, caminho asfaltado, caminho aberto, caminho da água, caminho dos animais etc. No que se refere aos tempos dos trajetos, também se reconhecem expressões que indicam quantificações, como caminhar dia (um dia de caminhada incluindo paradas) ou caminhar manhã adentro etc.

\section{1 - Conhecimento dos caminhos}

Durante o percurso, o que é considerado relevante (como indicações de movimento e vetores de direções) é descrito e exemplificado. Dá-se indicações sobre distâncias e aparências de acordo com o que se apreende do caminho e lugares. Descrever 
as rotas implica nessa internalização da paisagem que termina por ser apreendida no momento do percurso.

Todas estas funções são colocadas às pessoas, aos poucos, em um processo de aprendizagem e apreensão do mundo. Assim, as mulheres têm vários relatos de como elas acompanharam e hoje levam os seus filhos e netos em passeios pelos caminhos da serra. Nesses "passeios", elas ensinam às crianças a maneira que é considerada correta para se comportar e, desta forma, também ensinam sobre o ritmo dos caminhos:

1-) Ritmo. O ritmo a ser seguido. Não se deve correr muito à frente porque ser perdido de vista é perigoso e porque, ao correr, cansa-se mais; existem locais exatos para se fazer as paradas, as quais, se não são marcadores muito destacados dos demais, na sua maioria, designam por nomes simples (como a pedra grande, a viradinha ou coisas assim).

2-) Trajetos. Como e por onde deve-se andar. As crianças são ensinadas que não devem se aventurar pelas bordas ou tentar cortar caminho por onde não haja uma marcação, não devem seguir os animais, estes vão por outros caminhos que não são de fácil percurso para os humanos.

3-) Segurança. Não se deve andar muito à frente do grupo, ou se afastar, manterse em movimento durante o período de luz e não correr o risco de estar perdido à noite.

4-) Reconhecimento. Deve-se reconhecer os caminhos, os marcadores e os locais, a todo momento as direções são indicadas e quais casas estão nas redondezas. Também são colocados lugares que podem ser perigosos e não devem ser visitados.

Desta forma, aos poucos, as crianças aprendem como se comportar nos caminhos, são introduzidos a uma paisagem cultural cheia de informações simbólicas e práticas que devem fazer uso - ou ao menos conhecer -. Estes itens destacados passam a ser internalizados e naturalizados.

Todos estes elementos juntos definem as rotas. As distâncias e o modo de movimentar-se são implicados por esses elementos, eles ditam o ritmo do movimento, sendo que as direções geralmente são para acessar locais interessantes do ponto de vista pastoril (pastagens, água ou refúgios). 


\section{2 - Sobre rotas}

As rotas também apresentam um caráter emocional. Isto quer dizer que não é apenas prático, como aquele lugar onde é mais fácil andar, uma vez que ligam pontos de referência. As rotas implicam na relação que as pessoas apresentam com os lugares, por isso é possível afirmar que são repositórios de ações e histórias na paisagem.

Assim como no caminho feito com Dom Yucra, cada local acessado contém as lembranças transformadas em informações das diversas vezes que se fez o trajeto. Cada ponto da paisagem transformava-se naquela paisagem que Dom Yucra experienciou durante a vida, portanto uma rocha pode ser simplesmente uma rocha ou representar diversos significados, variando com a escala e com a perspectiva de quem a observa.

No local de parada, Dom Yucra indicou que, para ele, aquele lugar representava um pequeno descanso, pois não vinha de tão longe, porém para outras pessoas era um local de descanso mais prolongado, ou ainda (diante de garrafas que havia no local) era um lugar onde as pessoas hoje estavam indo para tomar bebida alcoólica. Assim, cada lugar representa os múltiplos significados simbólicos que lhe são dados, que implica os valores diversos que as pessoas definem a partir da sua própria história.

Essa memória é uma ferramenta de historicidade, porque produz identidades individuais e coletivas. A memória, contextualizada em lugares e práticas, integra os eventos do passado e permite dar fundamento a um significado compartilhado. Os eventos e as representações do passado constroem-se a partir da memória e dos lugares que a implicam. Assim, a história veicula a construção de algo sólido em relação à subjetividade e singularidades dos códigos simbólicos que os grupos produzem (Gaulejac e Silva Ochoa 2002).

O código simbólico e o sistema de crenças de um grupo ordenam o espaço e o conceituam, simbolizam o lugar a partir das práticas rotineiras. O tempo reflete-se e pode ser percebido, a partir dessas práticas sociais. Desta forma, apreender um lugar implica conhecer os instrumentos de conhecimento e de comunicação de um grupo.

Os sistemas simbólicos e as formas de classificação de mundo são também formas de comunicação e legitimação. Deste modo, as formas de comunicação também constroem enunciando e afirmando coisas e percepções através das pessoas, ordenando inclusive as categorias do tempo e do espaço. Assim, os caminhos e lugares retomam 
memórias, ajudam as pessoas a resgatar eventos e história em contextos geográficos e concepções temporais particulares e integram uma condição real (física) a uma condição subjetiva (ordens culturais) (Zedeño et al 2009).

A paisagem constitui-se na relação entre as duas capacidades do habitus, a de produzir e a de diferenciar práticas que implicam na apreensão e naturalização do espaço. As diversas percepções de mundo levam à criação de componentes diferentes na paisagem. Assim, o modo de uso do espaço e o entendimento deste indica a sua ocupação e a identidade. A reconstrução da história dos materiais em um território pode indicar as trajetórias de um grupo em uma paisagem e dar suas diretrizes identitárias (Zedeño 1997).

Portanto, a paisagem não é apenas construída, mas também constrói, é significada e também significa o mundo, é contextual e histórica, compreendida a partir das experiências acumulativas (Barrett 1999). Os contextos ideológicos do passado geram condições no presente com as modificações humanas do ambiente. O espaço como interação social, econômica e política imprime uma identidade específica. A paisagem é uma marca importante de identidade de um grupo. Nela estão demarcados seus limites, seus hábitos de subsistência, suas relações regionais com o ambiente e com outros grupos humanos e suas condições históricas (gênero, classe, religião, ideologia), pois é na paisagem que todas estas instâncias concluem e se ordenam num contexto específico (Zedeño 1997).

Existe um contínuo trabalho de significação e produção de conceitos ao redor dos lugares. Em torno deles, existe sempre uma reapropriação, manutenção e rememoração de coisas e histórias. A percepção sobre a relação entre o espaço e o lugar permite alcançar essas formas de resgate e materialização de coisas e pensamentos em locais reais. Caminhando é possível ver os índices e sinalizações necessárias para se seguir um caminho, mas para isso é preciso compreendê-los dentro da lógica específica que lhes dá sentido, desta forma, um marcador de caminho pode ser simplesmente uma pedra, ou pode ser um marco importante para indicar onde se deve descansar, ou tomar a direção leste ou oeste, por exemplo.

Por sua vez, a percepção dessas noções de espaço e lugar também atua na construção dos corpos e nas ordens culturais, que imprimem um modo de mover-se e se comportar. Por exemplo, saber como andar e quando parar, para Dom Yucra. O ritmo do caminho é determinado pelos locais de parada aliados ao tempo e esforço da caminhada. 
Portanto, existe um poder envolvendo a construção dos lugares, principalmente no que concerne à manipulação das práticas espaciais humanas. A noção de lugar é plausível de definição porque a sua representação existe na memória, que pode ser acionada a qualquer momento. Esta noção está relacionada à construção significativa de um local, que implica em um pensamento e na ação que acessam diversas escalas: paisagem, territórios, comunicação, construções individuais, corpos etc.

No processo de movimento, reconhece-se e retoma-se na memória o conhecimento, observa-se e apreende-se o entorno. Assim, os trajetos e o conhecimento são descritos aos outros, descreve-se a aparência de certos indicadores e os dados de proximidade e distância que se conhecem. Descrever as rotas implica a internalização da paisagem à volta, mapas cognitivos começam a ser formados, codificando o meio de forma inteligível. A partir dos sistemas cognitivos, percebe-se o que se deve ver e o que é possível, assim passa-se conhecimento espacial, através de códigos inteligíveis culturalmente. Caminhar pela paisagem é produzir uma inscrição cultural nela (Zedeño et al 2009).

A proposta deste capítulo é discorrer sobre os modos como o movimento implica lugares e trajetos, permitindo perceber e reconhecer a paisagem, pois a lembrança de jornadas aciona uma série de informações psíquicas e materiais. Desta forma, os elementos da paisagem - como uma pedra, o pico de uma montanha, a cerca de um vizinho, entre outros - não são classificados isoladamente, mas são como gatilhos para histórias narradas. Assim, aqueles que as ouvem e as vivem desenvolvem um conhecimento ao longo dos caminhos andados e das jornadas contadas. O movimento, por si só, é uma forma de conhecimento.

O conhecimento das pessoas sobre a paisagem vem, por um lado, do movimento através dela, e por outro, das histórias que se contam sobre essa paisagem. Conhece-se a paisagem por experiências objetivas, pois depende do movimento ativo. Este deixa traços na paisagem, é um processo de apreensão e manipulação (limpeza de terreno, construções, $\mathrm{o}$ ato de caminhar e de descansar etc.). A paisagem é definida e categorizada: existindo lugares que são acessíveis e outros que não são. 


\section{5 - PAISAGENS CONTEMPORÂNEAS. Uso e representação de sítios nos dias atuais.}

No capítulo anterior se fez uma breve introdução à noção de paisagem e aos elementos que constituem essas paisagens pastoris, destacou-se a importância dos caminhos para a atividade pastoril. Os elementos da paisagem são trazidos com a intenção de mostrar o caráter multitemporal dos mesmos.

Tomando como ponto de partida três áreas delimitadas artificialmente, far-se-á um levantamento sobre as informações arqueológicas e as interpretações das populações atuais sobre essas áreas. A proposta é mostrar que a paisagem integra múltiplas características a partir da significação daqueles que a vivenciam.

1 - Retomando a noção de paisagem

No capítulo anterior, destacaram-se os aspectos complementares das paisagens do movimento: o comportamento e a memória. $\mathrm{O}$ primeiro referente ao ato de viajar e o segundo à internalização da paisagem, durante a viagem. Na interação com a paisagem, estes dois aspectos integram conhecimentos antigos aos novos através do ato de caminhar, dos símbolos e de histórias (Zedeño et al 2009). 
Contidos na paisagem existem lugares. Estes são significados para os grupos específicos, através das experiências do dia-a-dia e das histórias que lhes são associadas. Cada lugar - seja um local ou um caminho - contém: conhecimento, histórias, materiais, entidades etc. Os lugares são gerados e mantidos pelas práticas específicas das pessoas no uso e nos movimentos cotidianos, que permitem às pessoas imprimir sentimentos e sensações aos lugares. No processo de interação do corpo humano com os locais geográficos, as experiências transformam aspectos subjetivos em condições concretas (Harmansah 2014).

Através das rotas e caminhos, discutiu-se sobre os lugares significativos e a relação com a performance corporal no movimento através da paisagem. Esses trajetos conectam lugares no processo de habitar, criando uma rede de assentamentos e zonas ecológicas indispensáveis para os grupos. O desenvolvimento das sociedades está intrinsicamente relacionado à terra e aos seus recursos. Essa relação pode ser compreendida a partir do contexto da relação entre as sociedades e o território ocupado. Porém, as histórias das unidades de ocupação não são lineares, os territórios mudam constantemente para se acomodarem às exigências e perspectivas. No registro de uma paisagem, é possível identificar os processos que a criaram. Interpretar esse registro permite entender todo o contexto de construção dessa paisagem (Zedeño 1997).

No processo de construção de uma paisagem estão contidos: a) a ação humana, que não é linear, mas acumulativa; b) os processos econômicos e sociais, plausíveis de serem compreendidos a longo prazo; c) os resíduos de processos do meio ambiente, que insinuam tanto nos efeitos dos humanos, como os da própria ação da natureza. Portanto, em uma paisagem contemporânea sobrevivem estas ações, fazendo o passado e o presente fluírem através do tempo, indicando a história de ocupação daquele espaço e a reprodução desta ocupação (McGlade 1999).

A temporalidade existe na relação entre as pessoas, nos ciclos e ritmos da vida social. A paisagem é uma forma acumulativa das vidas que se deram naquele ambiente, e está sempre em construção (nem construída, nem não construída), já que os homens escrevem a sua história de vida no natural junto ao ciclo de vida das plantas e animais. Por isso não é artificial nem natural, mas uma interação de atividades e experiências em vários processos, nos quais, o homem - integrado à natureza - é construtor de percepções e texturas de uma paisagem. Assim, não há necessidade de diferenciar a materialidade e 
a impressão de significados culturais, a paisagem constitui-se a partir do ato de habitar um determinado lugar (Ingold 2000).

Portanto, são as experiências diárias das pessoas, a maneira como vivem e trabalham que constroem e reconstroem a paisagem e o material que deixam como traços dessa atividade (Johnson 2007). As atividades diárias, a prática, fala-nos sobre a maneira como a estrutura e as normas culturais são traduzidas em ações, assim o movimento e a atividade nos espaços outorga significado dentro de um processo de reprodução das relações sociais.

Desta forma, a apreensão de uma paisagem está presente no movimento dos dias, na percepção da terra, no uso dos recursos. A paisagem existe no âmbito cotidiano. No ambiente de campo, onde a observação participante exige fazer parte das atividades do dia-a-dia, isto fica claro, pois é nas atividades mais simples, nas mais corriqueiras que é possível perceber como as pessoas apreendem a paisagem que as rodeia e que também a constroem. Por exemplo, em várias manhãs, Guadalupe deve sair para conseguir lenha para a sua cozinha. É no percurso para realizar essa tarefa doméstica que ela e os filhos acessam esses marcos na paisagem e interagem com o ambiente que os rodeia, muitas vezes, contextualizando e naturalizando as marcas do presente e do passado de maneira quase imperceptível no dia-a-dia.

O processo de percepção de uma paisagem implica a habilidade das pessoas de ver e orientar-se através dos traços que lhes são indicativos da sua própria existência. Dentro do contexto sociocultural específico, considera-se a concepção de tempo e de espaço e das manifestações da ação social juntamente à ação do ambiente, as representações podem ser experienciadas na paisagem como produto da agência humana e com isto abre-se espaço a uma instância própria de compreensão do entorno. Assim, os lugares são espaços construídos e modificados pela ação humana e, a partir da memória, são repositórios de ações através do tempo, transformando o passado em metáforas tangíveis no presente. A própria existência dessa paisagem, para essas pessoas, implica conseguir identificar os marcos e os caminhos, sendo que, quando se fala desses marcos, cada um tem uma significação e uma particularidade, pois existem no ato cotidiano e na própria história de vida (Johnson 2007; Darvill 1999).

A discussão apresentada anteriormente diz respeito à paisagem e à forma como estas pessoas percebem e apreendem a paisagem à sua volta. Diante disto, é possível 
compreender a paisagem como um espaço ativo de reprodução social, com interpretações e reinterpretações, como algo construído e categorizado em termos sociais.

Portanto, ao falar em paisagem está se falando de espaço e tempo de maneira integrada e indissociável, pois a paisagem é a intersecção de diversas temporalidades e da ação dos humanos que, conjuntamente, constroem o material. Toda característica da paisagem detém uma vida e as mudanças a longo prazo, ou seja, uma biografia. Quando se trata de análise de paisagem, também é preciso lidar com os objetos - artefatos e/ou construções - que extrapolam o momento em que foram produzidos, podendo ter feito parte de vários períodos da ação humana ${ }^{24}$ (Barrett 1999).

Os caminhos recortam a paisagem e a produzem, ligam lugares e são lugares porque eles em si têm significados. Estes caminhos são o fruto da interação entre terra, animais e pessoas, e marcam os percursos e os ritmos, impondo uma experiência e exercendo uma agência sobre quem os percorre, o que implica uma performance determinada e uma definição de espaço e, consequentemente, de lugar. Os caminhos e os lugares resultam da alteração da paisagem através da ação cotidiana e explicitam conceitos como tradição, espiritualidade e também a identidade, já que é o conceito básico da mobilidade que integra todas estas instâncias (Ferguson e Colwell-Chanthaphonh 2006).

Como elemento ativo, a paisagem agencia o comportamento e a identidades das pessoas, produz identidade. A identidade desses pastores com a paisagem é renovada constantemente no seu processo de mobilidade. Nos seus trajetos e nos lugares que alcançam, entram em contato com o registro das diversas ocupações, o qual identificam e traduzem para os contextos atuais. Estes pastores retomam a memória e o passado, mas não como contemplação, pois o resgate acontece na vivência, é uma relação fenomenológica com os espaços e o conhecimento que, a todo momento, remete a tradições e ancestralidade.

Assim, quando se analisa uma paisagem, é necessário considerar o tempo e o espaço interligados às condições históricas indicadas pela ocupação humana e levar em

\footnotetext{
${ }^{24}$ Ainda quando não é possível indicar uma datação exata, porque certos objetos atravessam ciclos de vida humanos, ainda é possível contar a história do lugar e dos momentos em que um ambiente passa a ser considerado significativo, considerando, junto com a modificação do ambiente, um engajamento e experiências subjetivas de quem vive naquele espaço (Barret 1999).
} 
conta as possíveis interações e extrapolações do tempo (Jiménez 2004). As noções de tempo e espaço e a maneira como se articulam, também são categorias fundamentais, principalmente no que se refere à compreensão da paisagem arqueológica e suas inferências no presente. O código simbólico e o sistema de crenças de um grupo ordenam o espaço e o conceituam, simbolizam o lugar a partir das práticas rotineiras definidas pela estrutura social, criando e recriando classificações (Bourdieu 1989). O tempo é refletido por essas concepções de universo dadas pelo corpo social, uma vez que as características e classificações são fluidas, e esta fluidez também se apresenta no material. Existe uma relação significativa entre o território, as pessoas e sua história, de forma que as diversas percepções de mundo levam à criação de componentes diferentes na paisagem (Arango e Andoque 1999).

Por sua vez, nos passeios, histórias são contadas, o entorno é indicado e são as relações com o restante dos caminhos e lugares que são ressaltados e, junto às indicações, mostravam-se marcadores da paisagem, descritos pelas suas aparências e vetores de movimento necessários para se chegar, além das circunstâncias de onde havia uma casa de um vizinho, de onde havia pastos bons para os animais, ou boa lenha, ou áreas onde se mantém água por mais tempo.

Portanto, é preciso considerar que a paisagem integra na terra a experiência humana e a expressão dessa experiência opera nos diferentes níveis de significados (Zedeño 1997). Isto porque as marcas na paisagem - da topografia e das construções surgem à vista, fazendo que aquele que se move através dela reafirme a sua relação com essas marcas, reconhecendo codificações culturais. A relação entre caminhos e lugares pode ser compreendida ao considerar-se o movimento. As paisagens, portanto, representam as múltiplas narrativas dos diversos tempos em questão. A ideologia e o sistema de classificações estão envolvidos na criação inconsciente e deliberada da paisagem como expressão de uma identidade cultural. Contextos ideológicos do passado geram as condições do presente, assim como as modificações humanas do ambiente, a introdução de novas técnicas e produtos (escolhas e atos) podem determinar a evolução da trajetória do sistema, levando a resultados irreversíveis. Assim, a paisagem não é apenas um acúmulo de ações, mas um conjunto de estruturas e dispositivos que existem significativamente em entidades ativas como agentes da ação social (Darvill 1999). 
Desta forma, o conceito de paisagem integra as diversas categorias que constituem um território para um grupo, como as construções sociais e ideológicas, os recursos e a ação humana. Através do tempo, o registro material dessas interações e atividades refletem os ajustes das estratégias de uso da terra que implicam mudança e permanência na paisagem. Como modificação da paisagem, destacam-se as atividades envolvidas na organização e discriminação dos espaços vividos. Tais modificações são acumulativas, podendo representar continuidades de uso ou rupturas através do tempo. As atividades produzem alterações na paisagem, que atravessam todos os espaços com outros comportamentos de uso da terra, sendo assim, é possível perceber, no processo de uso e apreensão da paisagem, as múltiplas escalas temporais nas ocupações que ali ocorreram e na maneira como as pessoas apreendem essas ocupações no presente.

A seguir destacar-se-ão algumas áreas que integram antigas ocupações précolombianas às atividades do presente. $\mathrm{Na}$ análise desses lugares, a intenção é compreender como o registro arqueológico influencia e afeta as populações do presente, como as famílias de pastores. Para tanto, far-se-á uma breve discussão dos registros arqueológicos mais evidentes de cada lugar, para logo descrever como as pessoas interagem diretamente com esse tipo de registro.

\section{2 - Percepção e paisagem}

A discussão deste capítulo centrar-se-á na zona de Santa María, especificamente na serra do Cajón. Esta é uma área de intensos estudos arqueológicos, diversos sítios foram delimitados e estudados, ainda assim é uma área de fluxo de pessoas que convivem diariamente com esses sítios arqueológicos. Nesse processo de integração entre as informações pretéritas e as informações atuais existem várias linhas de convergência e divergência. No decorrer deste capítulo dar-se-á especial atenção a três áreas, delimitadas artificialmente a partir dos lugares que as pessoas acessam.

Na figura a seguir, estão indicados alguns dos sítios arqueológicos da zona e as três áreas que foram visitadas. 


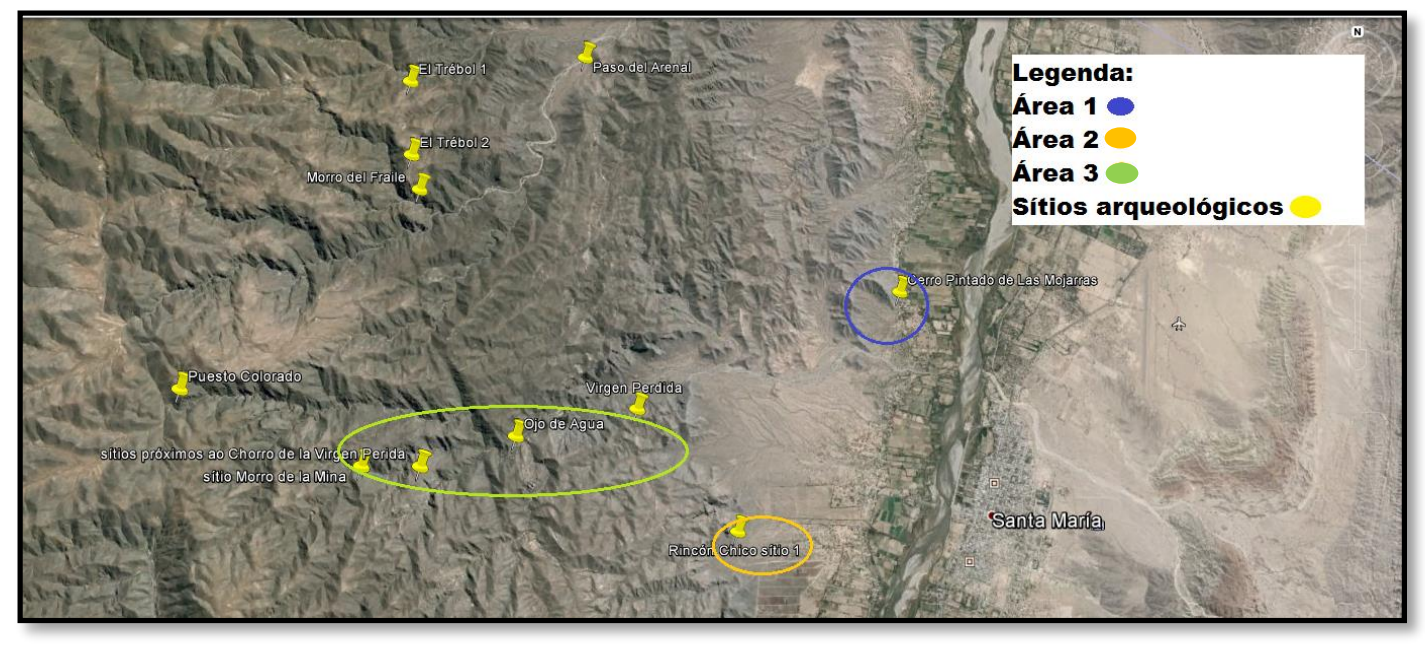

Figura 45 - Imagem indicando o mapa com as áreas destacadas e a presença d e alguns sítios arqueológicos associados.

\section{1 - Sobre as áreas}

Como foi indicado no capítulo 1, a região do vale de Santa María sempre foi uma região de intensa ocupação. Esses diferentes momentos de habitação da zona implicaram um determinado registro na paisagem. Nos dias atuais, grupos vivos convivem lado a lado com sítios arqueológicos, identificando-os e dando-lhes sentidos variados de acordo com as necessidades do momento.

Por sua vez, o uso de certas áreas faz-se recorrente, ainda que não seja possível indicar com exatidão os diversos sentidos que as populações deram aos mesmos locais, é possível atestar a presença dos diversos grupos, ao longo do tempo. A paisagem, muitas vezes, funciona como um elo entre os acontecimentos do passado e do presente, permitindo às pessoas acessarem esse repertório de informações no simples ato de caminhar. Os lugares passam a ser conhecidos e apreendem-se as características da paisagem em questão, são feitas interpretações e reinterpretações sobre aquilo que se está vendo. Essas interpretações integram os vários tipos de informações (do cotidiano, do sistema político do econômico, de identidade etc.) e assim definem-se os lugares.

Sobre os registros arqueológicos destas áreas delimitadas, é possível relacioná-los com o período anterior ao avanço incaico no vale de Santa María, o qual caracteriza-se pela presença de padrões de assentamento em conglomerados com segregação espacial entre áreas residenciais e áreas produtivas. Estes conglomerados aparecem localizados 
próximos ao rio Santa María, sobre as ladeiras da serra do Cajón, no contato entre as ladeiras e as serras. Acredita-se que são locais de moradia com um alto índice populacional, possuem setores protegidos por estruturas que são consideradas como defensivas e destaca-se a presença de arquitetura pública (praças, plataformas, depósitos, morteiros etc.) junto a conjuntos habitacionais que parece terem sido destinados à elite (Williams 2003; Nastri 1997-8; González e Tarragó 2005).

As unidades de moradia, relacionadas diretamente ou nas proximidades das áreas de exploração, são mais simples. Nesta mesma área, também se encontram as chamadas instalações produtivas, as quais podem ser divididas em três tipos arquitetônicos: a) aquelas unidades associadas às áreas de cultivo, que se encontram nas áreas mais baixas e próximas ao rio Santa María; b) os sítios associados a locais de água e pastagens, que puderam estar relacionados a outros do interior da serra; c) os chamados postos (puestos, em espanhol), que foram considerados como unidades defensivas e de controle da área, também relacionados a este tipo de complexo (Nastri 1997-8).

O centro povoado ou pukara (ou ainda pucará) é reconhecido como unidade mínima de assentamento para este período. Por sua localização e suas estruturas circundantes na ladeira são considerados centros fortificados (por isso, chama-se pukara). A ideia do "pukara" vai além da simples concepção de uma fortaleza, no seu conceito, o pukara sobrepunha a relação de proteção/vigilância às dimensões simbólicas em relação ao que significam as serras e a ideia de verticalidade andina. Acredita-se que a junção entre chacras (instalações basicamente agrícolas) e o pukara (centro social, político e religioso) integrariam a dinâmica do período. Estes núcleos populacionais destacam-se pela modificação do entorno, as construções nas ladeiras das serras renderam monumentalidade e visibilidade que prevalecem até os dias atuais. As características espaciais das construções provavelmente estavam representando e reafirmando práticas socioculturais junto à cosmologia andina, na relação com a importância das montanhas e serras para o ciclo da vida dos animais, plantas e seres humanos (Tarragó e González 2004b).

A imponência visual desses complexos povoados sobre a ladeira da serra permanece até os dias atuais. A transformação da paisagem que implicou essas construções arquitetônicas permanece perceptível, ainda quando estejam transformadas nas suas instâncias e conceptualizações. É possível que as percepções não sejam as 
mesmas, mas os dados etnográficos levam a crer que as mesmas características que suscitam a admiração das pessoas hoje sejam aquelas que levaram as populações pretéritas a construírem grandes conglomerados ligando o vale às serras. As ressignificações e o sincretismo por traz da persistência dessas paisagens construídas guardam informações valiosas de como os grupos do presente veem e se relacionam com o passado.

Juntamente a estes grandes centros povoados que se fazem visíveis nas subidas das serras, também permanecem uma série de ruinas nos antigos locais utilizados como áreas de captação e produção. Esses locais, de características arquitetônicas mais simples em comparação aos centros povoados, são importantes pelos recursos que ainda oferecem à população que mora nesses locais ou nas proximidades, portanto, permanecem significativos sob outra ótica.

Considerando-se a importância significativa destes lugares, tanto no passado como no presente, é possível inferir sobre os comportamentos atuais em relação à apreensão dessa paisagem pretérita. Apesar de que não é possível acessar as formas de pensamento daqueles grupos no passado, é possível afirmar que as mesmas áreas de captação de recursos estão sendo utilizadas. De um modo geral, as estruturas presentes nessas três áreas respondem às seguintes distinções: a) áreas de captação de recursos primários, correspondentes às áreas baixas dos antigos centros povoados; b) áreas de apreciação, correspondendo às áreas altas desses centros povoados; c) área de captação de recursos pastoris, correspondendo a áreas nas quais há presença de água e pastagens fora do período de verão.

Apesar da distinção formal, estas áreas respondem a mais de uma característica funcional, pois, como foi colocado anteriormente, a paisagem integra diversas expressões, sejam estas simbólicas, sociais, econômicas ou rituais. A única destas áreas que é também considerada como área de moradia é a área de captação de recursos primários. Já, as áreas de campo, que podem ser utilizadas para captação de recursos pastoris e primários, também apresentam características simbólicas e rituais integradas.

\subsection{1 - Área 1: O sítio arqueológico de Las Mojarras}


Sobre a ladeira da serra e com vista para o rio Santa María, surgem as ruínas de um centro povoado conhecido arqueologicamente como "Las Mojarras" e, entre a população local, como "Pucará". Pela contínua presença humana no local, é um sítio que foi pouco estudado (em comparação com outros centros povoados do vale, como Rincón Chico). Os vestígios arqueológicos mais conhecidos são referentes ao povoado alto denominado Cerro Pintado e ao material de enterramentos recuperados nas suas imediações.

No alto da serra, foi registrado um pequeno grupo de construções angulares, quadradas e retangulares alongadas, todas dispostas com certa simetria. A construção considerada como a principal destas edificações, constitui-se de um composto retangular, que mede aproximadamente 40 metros de comprimento por 12 metros, a qual parece ter servido de pátio, ao qual estão integrados recintos. No lado ocidental, estende-se uma grande galeria retangular apresentando uma forma que lembra um martelo, junto encontram-se outros três recintos menores: um perfeitamente quadrado, localizado no meio da parede Norte (que hoje encontra-se derrubada); do lado oposto, encontram-se os outros dois recintos, que apresentam formato retangular. No interior do grande pátio, existiu um círculo de 3 metros de diâmetro formado com grandes lascas de rocha (Tarragó e González 2005).

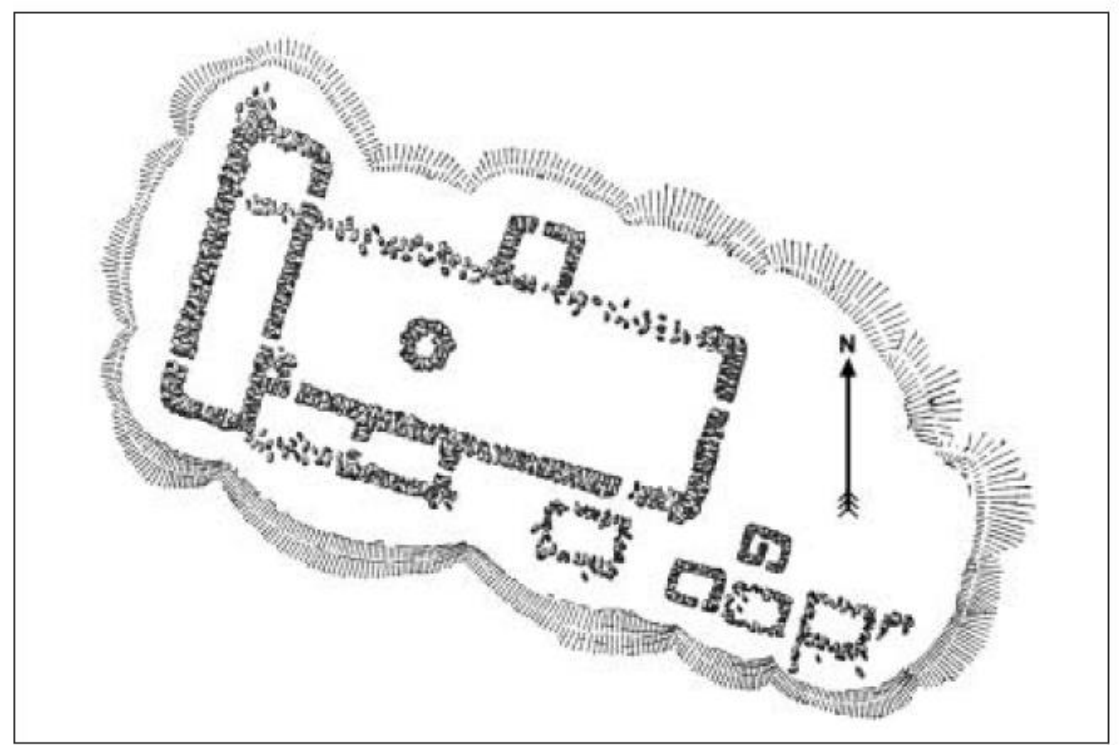

Figura 46 - Construções na parte alta de Cerro Pintado de Las Mojarras. Fonte: (Tarragó e González: 2005: 73). 
A aproximadamente 100 metros desse grande pátio central, registrou-se a existência de um recinto de 4 metros por 4,5 metros de fina edificação. Neste recinto, destaca-se a presença do que viria a ser o batente da porta desse recinto construído com grandes lascas e também a existência de um vão trapezoidal com os muros enfeitados com uma linha de blocos de rocha brancos a meia altura. Os autores comparam estas descrições às evidências encontradas em Rincón Chico (Tarragó e González: 2005: 73). A ladeira oriental da serra encontrava-se coberta por terraços contidos por muros de contenção, os quais serviam de via e base para recintos alinhados em toda a subida da ladeira. Ao Sul do complexo de Las Mojarras, foram registradas outras dez áreas constituídas por um grande recinto retangular com estruturas menores associadas em formatos retangulares e circulares. Em toda a área, resgataram-se fragmentos cerâmicos de estilos diversos (Santa María Bicolor e Tricolor, San José/Shiquimil, Famabalasto Negro Grabado, Famabalasto Negro sobre Vermelho e Inca Provincial). Também é indicada a presença de oficinas metalúrgicas a partir de um dos locais escavados, o qual registra grandes nódulos de escórias de combustão, refratários fraturados, restos de minerais de cobre e um pequeno fragmento de bronze estanífero (Tarragó e González: 2005: 72-5).

Entre a população local, esta serra é conhecida como Pucará ou Cerro Pintado. A nomeação é dada justamente pela experiência arqueológica que a subida da serra representa. Também se fala que muitos chamam-na Cerro Pintado porque antigamente era possível ver os muros nas ladeiras da serra, os quais eram decorados com blocos de rochas brancas sobre blocos de rochas da cor chumbo, dando à serra o aspecto de estar pontilhada de branco.

Certo ou não, para a população local - principalmente para os habitantes de Las Mojarras - essa serra tem uma representatividade especial. Como Pucará é vista como uma cidade indígena fortificada, incorpora um simbolismo particular em relação aos vários estágios da subida da serra, integrando referências a histórias pessoais, ao material arqueológico visível e suas possíveis significações e à relação deste lugar com o entorno. Foi possível observar essa relação em um dos passeios que fiz com as filhas de Dom Vicêncio. 


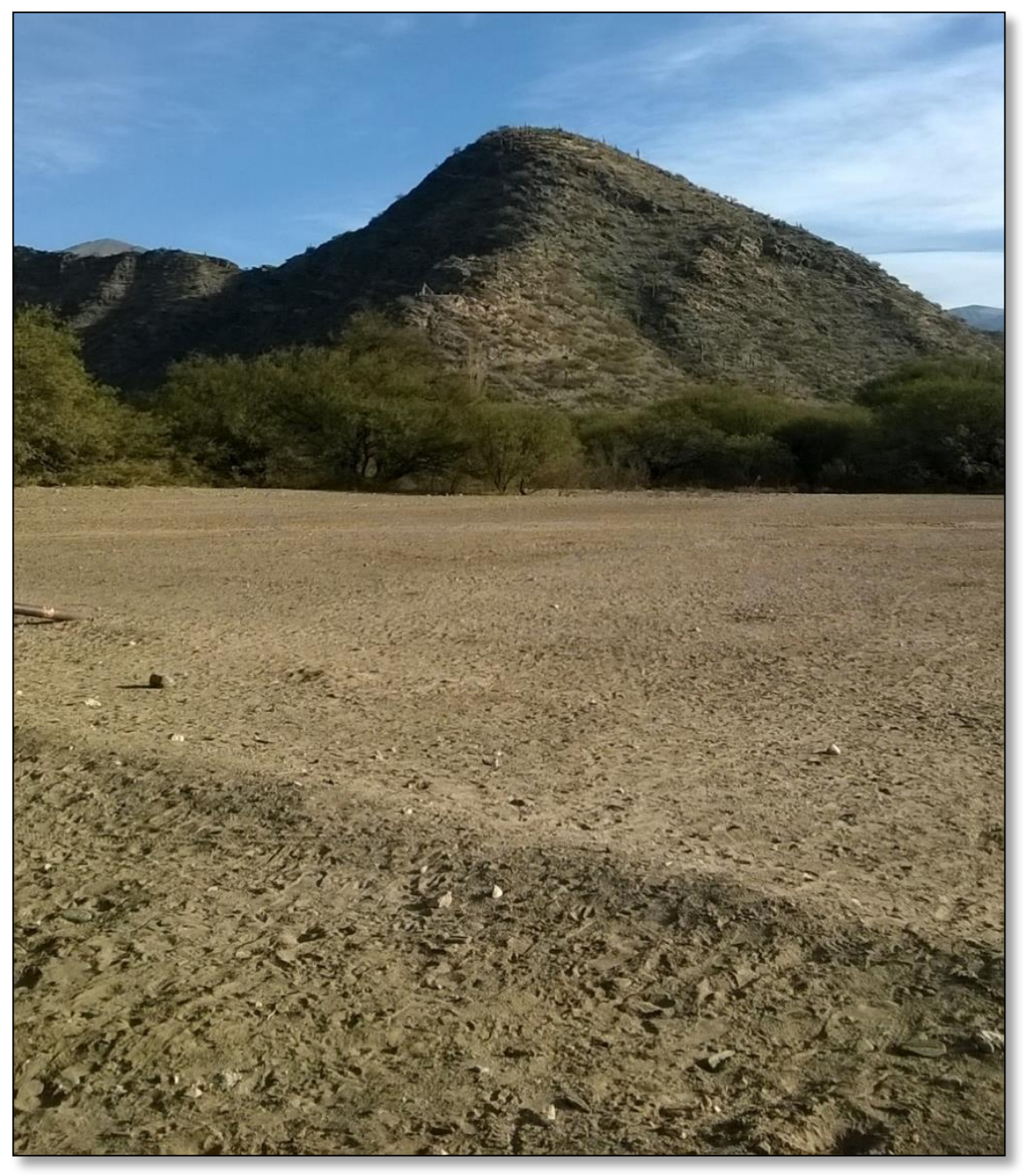

Figura 47 - Imagem da serra que incorpora as construções do Cerro Pintado Las Mojarras. Vista desde as proximidades da casa de Dom Vicêncio.

A serra está localizada nas imediações da propriedade de Dom Vicêncio. Olhando desde baixo, a visão que se tem é de terra, rochas e plantas nas encostas dessa serra, as construções não são mais visíveis à distância. As diversas construções e ruínas do Pucará somente são visíveis na subida da serra. É provável que, na parte baixa do complexo Las Mojarras, estivessem as instalações produtivas referentes ao centro povoado. A presença de diversos assentamentos modernos dificultou os estudos na zona (Tarragó e González 2005). Nesta área baixa, está localizada a casa de Dom Vicêncio, entre outras tantas e, aflorando no solo arenoso que compõem os arredores da casa de Dom Vicêncio, é possível encontrar diversos fragmentos cerâmicos, muitas vezes com a pintura ainda visível. A população local não se interessa por esses fragmentos. Estas pessoas acreditam que deve ser mantida uma distância entre as pessoas vivas e certos restos arqueológicos (como os 
fragmentos cerâmicos), os quais não devem ser levados às casas ou guardados. Cruzar com ruínas e restos materiais no campo não é problemático, apenas não devem ser apropriados por alguém.

Porém, passeios por entre ruínas e ao alto desta serra são muito comuns, principalmente entre as filhas de Dom Vicêncio, que consideram que é um trajeto próximo à casa, conhecido e sem muita dificuldade. Elas costumam levar as crianças desde pequenas para aprenderem como se comportar na serra, antes de fazerem trajetos mais longos.

O caminho é feito com duas paradas, a primeira em um calvário construído para uma virgem da religião católica e a segunda na cima da serra. A subida não é muito sutil, mas é tranquila, pois a trilha é bem demarcada e cuidada. Há alguns anos havia um cuidador presente para cuidar do complexo Pucará, porém hoje os cuidados ficam em mãos dos moradores locais.

Conforme a subida avança, é possível identificar muros e recintos. Às vezes, o trajeto é feito acompanhando esses recintos, em outras, segue-se por cima de uma espécie de muros que formam a continuação do caminho.

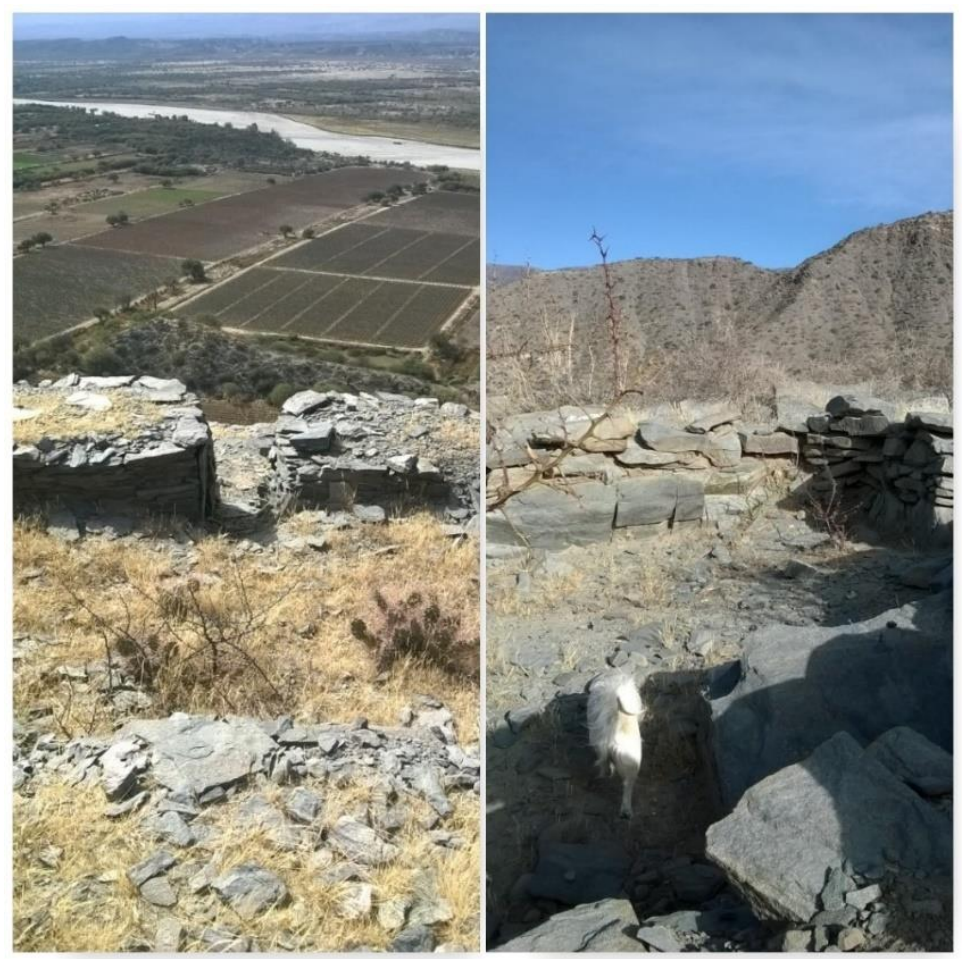

Figura 48 - Imagens ilustrando os trajetos. A imagem à esquerda indica o trajeto por entre os recintos, e a imagem à direita indica o trajeto que contorna os recintos. 
Para a população local, esses muros e recintos, representam as casas daqueles que ali viveram e que acreditam que exerceram atividades muitos parecidas às que as pessoas dos arredores têm atualmente. Para a população local, um dos indicadores dessa atividade (além do lugar) é a presença de certas plantas que eles consideram essenciais para o pastoreio, um deles é o cardón (Pachycereus pringlei). A madeira desta cactácea é utilizada na construção (principalmente de currais e porteiras) e a parte interna é moída e dada de alimento para os animais. A presença de grande número de cardones em toda a ladeira da serra é um marco importante que atesta a identidade destas pessoas com o passado do lugar.

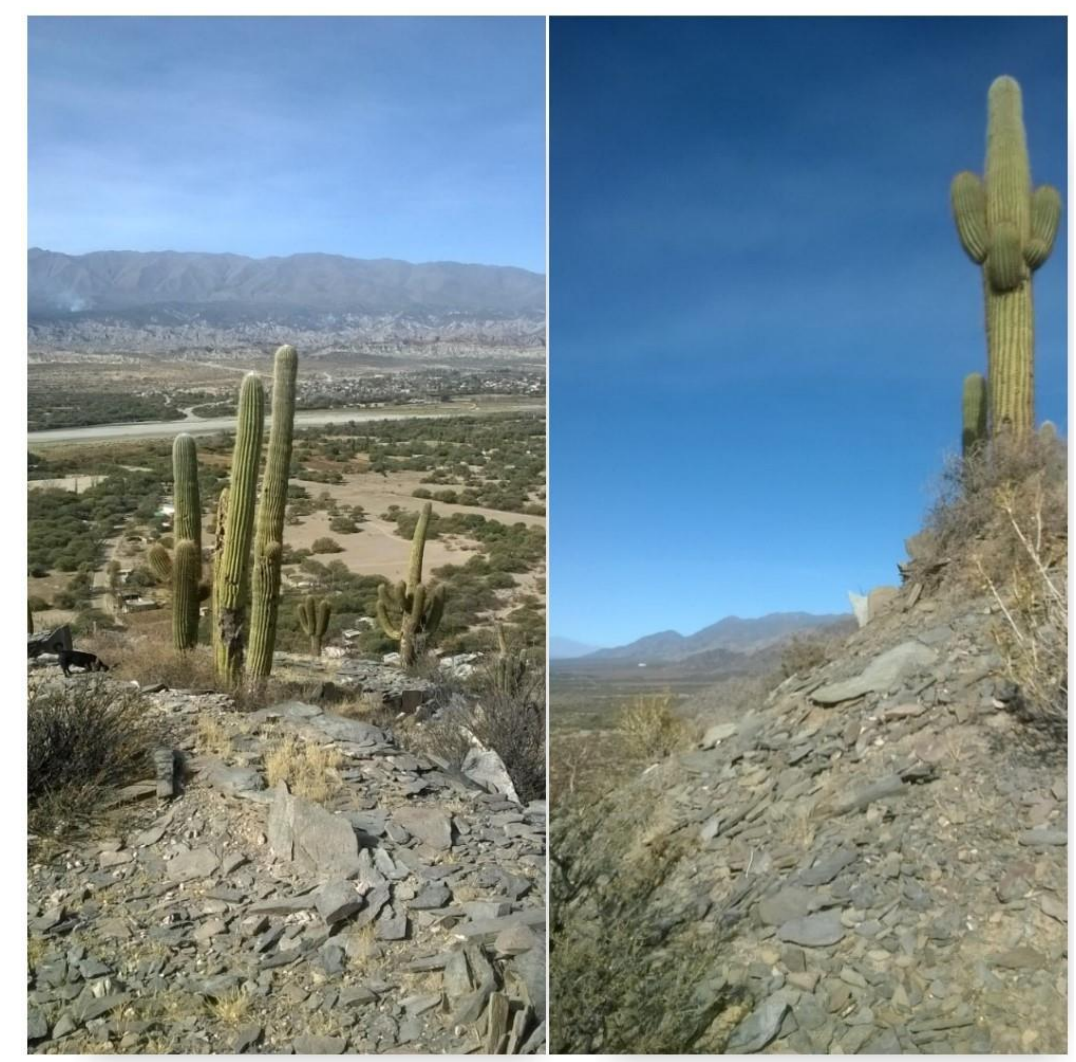

Figura 49 - Imagens indicando a presença de cardones por entre as ruínas.

A primeira parada é em uma pequena parte plana na metade do caminho. Ali está localizado uma espécie de calvário que guarda uma imagem de uma virgem católica. Entre os moradores esse lugar, é conhecido simplesmente como “a virgem”. Essa primeira 
parada é muito representativa para a população local, pela presença da imagem da virgem católica, que dá a referência do lugar e implica procissões e às vezes até missas, e pela facilidade de chegar.

A relação destas pessoas com o Pucará é sincrética. As filhas de Dom Vicêncio contam que um professor de educação física da escola próxima, utilizava essa subida como atividade de aula, fazendo que os alunos subissem até a virgem e descessem no trote e isso era a avaliação final da matéria.

A parada do calvário é visitada com frequência por moradores locais (principalmente) e por alguns turistas. Existem anúncios de expedições turísticas que passam por estas ruínas, em páginas na internet e na cidade. Por isso, nas imediações do calvário, existem escadarias e parapeitos. No percurso da subida da serra, este é um lugar para descansar e seguir andando (comum para os caminhos, assim como foi indicado no capítulo anterior). Desse lugar, é possível avistar outros complexos de povoamentos antigos como Fuerte Quemado ${ }^{25}$ e tem-se uma vista ampla do rio Santa María.

Este lugar também foi cenário, durante muitos anos, de uma encenação no dia do índio ${ }^{26}$, os alunos da escola (e isso inclui as filhas de Dom Vicêncio) começaram a fazer uma representação teatral sobre um momento muito marcante para a população atual da resistência indígena frente ao domínio colonial. A encenação consistia na representação dos indígenas que resistiram ao avanço colonial. Assim, alguns jovens ficavam no alto do calvário representando os indígenas, a serra era iluminada enquanto alguém contava a história. No final da história, os jovens desciam encenando a vitória de resistência indígena. Toda a encenação desenrola-se em torno de um cacique local que fez frente aos espanhóis, não permitindo o avanço sobre o Pucará, de forma que muitos habitantes permaneceram livres e resistindo. Esse cacique representa uma figura mítica importante na tradição local.

\footnotetext{
${ }^{25} \mathrm{O}$ assentamento Fuerte Quemado está localizado a $7 \mathrm{~km}$ ao norte da cidade de Santa María, consta de vários setores sobre a serra, na ladeira da serra e na planície aluvial. As descrições das peculiaridades arquitetônicas destacadas em Fuerte Quemado permitem pensar que, além de centro povoado, também funcionou como observatório astronômico. Também, destaca-se a presença de campos agrícolas, currais e morteiros comunitários. Também há indícios de ter funcionado uma oficina de metalurgia (presença de escórias de cobre, ouro e minerais fundentes), além dos distintos estilos cerâmicos coletados no complexo (Tarragó e Gozález: 2005: 70-2).

${ }^{26}$ Festejado dia 19 de Abril.
} 
A presença intensa de ruínas é um atestado da existência de população indígena há muitos anos, além de atestar a eficiência dessa população que, aos olhos da população local, esta eficiência é indicada pela permanência das construções apesar do tempo decorrido, portanto o lugar é visto como um marco decisivo de aproximação com um passado indígena e de distinção com o presente.

Despois da parada do calvário, a subida torna-se mais íngreme e as ruínas se intensificam até o topo. A segunda parada está no alto na serra, em uma zona plana e aberta (possivelmente a praça central indicada no texto de Tarragó e González (2005)), onde ainda persistem as bases de possíveis muros pretéritos, como montes de pircas e amontoados de rochas (possivelmente causa dos muros já caídos) e algumas formações indefiníveis a olho nu. Nesse local, as pessoas sentam-se comodamente sobre as ruínas, fazem piqueniques, apreciam a vista e contam histórias referentes às resistências indígenas frente ao avanço colonial. Nós nos sentamos no que possivelmente foi o muro da grande praça central do complexo olhando para o Norte. Às nossas costas foi possível ver os antigos parapeitos de contenção da serra, e ainda era possível observar alguns muros, ainda que sutilmente.

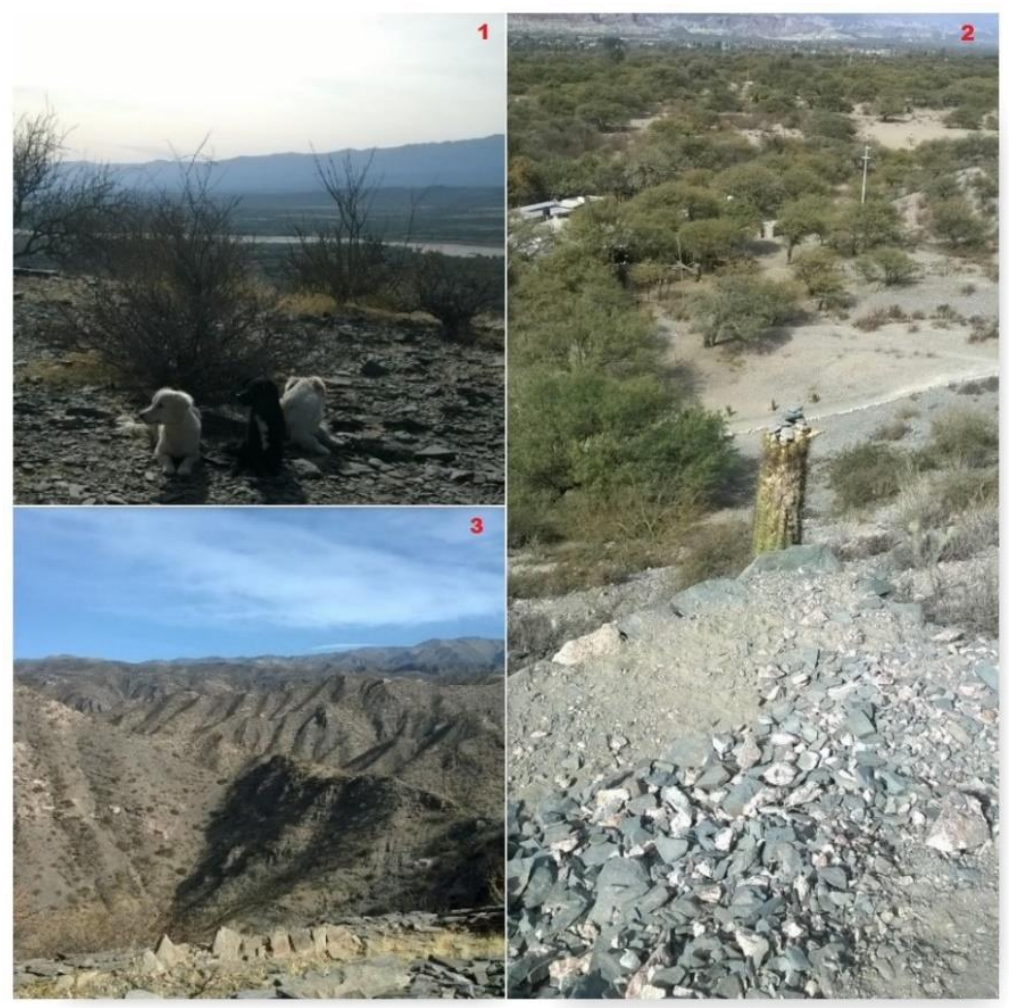

Figura 50 - Imagem indicando os restos materiais que ainda são evidentes na cima da serra. A imagem 1 e 2 indicam o perímetro da descida da ladeira ainda demarcado. A imagem 3 indica as lascas em pé que ainda persistem e que serviram de sustento. 
Um pouco mais a frente desse primeiro pátio aberto, onde as pessoas se sentam, existem outras construções. Uma é conhecida como a "casinha do índio" entre os moradores locais. São duas estruturas, a primeira apresenta-se em bom estado de conservação (a mesma descrita anteriormente por Tarragó e González (2005), localizada a 100 metros da praça central do complexo. Existem várias histórias sobre a permanência dos muros e da porta nesta construção. Dizem que um xamã morou ali e a reconstruiu. Dizem também que foi local de esconderijo durante muitos anos.

A alguns passos da casinha do índio, na encosta da serra existe um túnel com uma grande e profunda abertura de difícil detecção, as pessoas acreditam que esse túnel serviu de esconderijo para os indígenas durante a resistência pois, mesmo em pé sobre o que viria a ser o teto do túnel, não é possível visibilizar a entrada. É necessário descer um pouco pela ladeira para identificá-la.

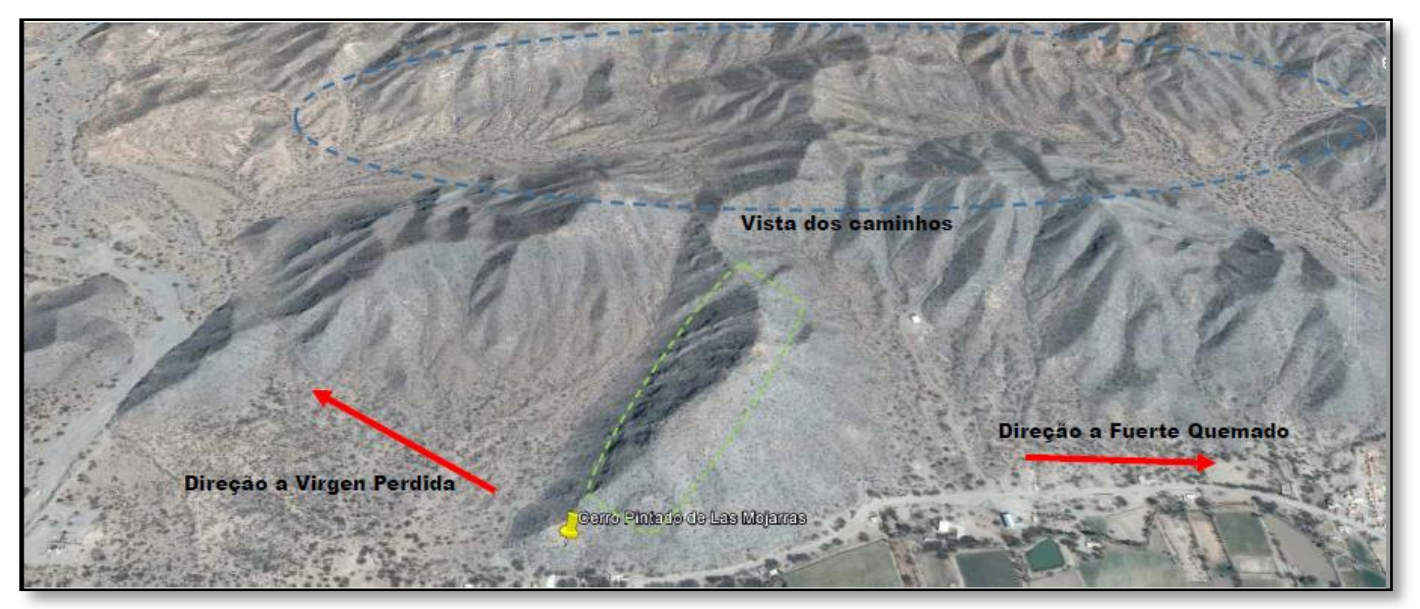

Figura 51 - Imagem indicando o local do passeio associado ao sítio arqueológico de Las Mojarras, (pontilhado em verde claro), com as direções e as vistas apontadas durante o passeio.

Desse local (de costas para o rio Santa María e de frente para a serra), é possível ver vários caminhos entrecortando as serras com descidas ao vale e continuação até o interior das serras, também há currais associados a esses caminhos. As filhas de Dom Vicêncio identificam vários caminhos que saem exatamente do ponto baixo do Pucará até vários locais, entre eles a Virgem Perdida (área 3). Frente a essa imensidão de caminhos que é possível acessar a partir do Pucará, as pessoas locais acreditam que esse lugar 
deveria ser um importante ponto de encontro, onde todos se reuniam para fazer festas e tomar decisões importantes, tal como um grande salão. Segundo contam as filhas de Dom Vicêncio, acreditam que vinham pessoas de todos os lados para se juntarem nesses eventos, assim como hoje se vai visitar outros sítios como Fuerte Quemado, mesmo morando em Las Mojarras. Elas acreditam que as pessoas iam para participar desses eventos, além de outras atividades. A partir das reflexões da população do local, pode-se dizer que os grandes centros povoados da zona, Rincón Chico, Las Mojarras, Fuerte Quemado, poderiam ter feito parte de um grande complexo de cidades conectadas, pois a forma de sobreviver até os dias de hoje, frente às adversidades econômicas, políticas e climáticas; é buscando a integração e as diversas áreas de recursos.

O passeio por esta serra povoada de ruínas em Las Mojarras é um momento de integração e reflexão sobre esse passado indígena que, literalmente, mora ao lado. Enquanto a parte baixa do que viria a ser este complexo povoado de Las Mojarras é uma área de moradia, criação de animais e pequena agricultura, a parte alta ainda mantém a magnitude de outros tempos, ainda que desde outra ótica. Hoje tornou-se um lugar de apreciação e de revitalização do passado indígena através dos restos materiais que ali persistem. A relação desse lugar com a população é de integração e rememoração de façanhas de populações indígenas, com as quais identificam-se principalmente por ocuparem as mesmas áreas.

Durante todo o percurso da subida do Pucará, aparecem pequenos montinhos de pedras cuidadosamente empilhadas. Estas intervenções são conhecidas desde os relatos dos primeiros contatos e são chamadas de huancas, que significa "pedra sobre pedra" em um idioma pretérito local (em locais dos Andes Centrais e Norte estas formações antrópicas também podem ser chamadas de apachetas). Acredita-se que essas pedras empilhadas representaram uma pluralidade simbólica como uma atomização das representações das serras, articulando um passado mítico com o real e legitimando a propriedade da terra (González e Tarragó 2005). No geral, estão localizadas ao longo dos caminhos, os limites das áreas de pastagens e nos passos (Kuznar 2001).

Ao perguntar sobre a existências de diversas huancas pelo caminho, a resposta foi muito próxima às definições colhidas. As huancas representariam a presença e o uso da terra em questão, a relação entre o céu e a terra. Essas intervenções presentes em todo o percurso do Pucará seriam feitas pelas pessoas que visitam o local, conforme relatam as 
filhas de Dom Vicêncio, com o intuito de passar o tempo e demonstrar que o lugar é utilizado constantemente.
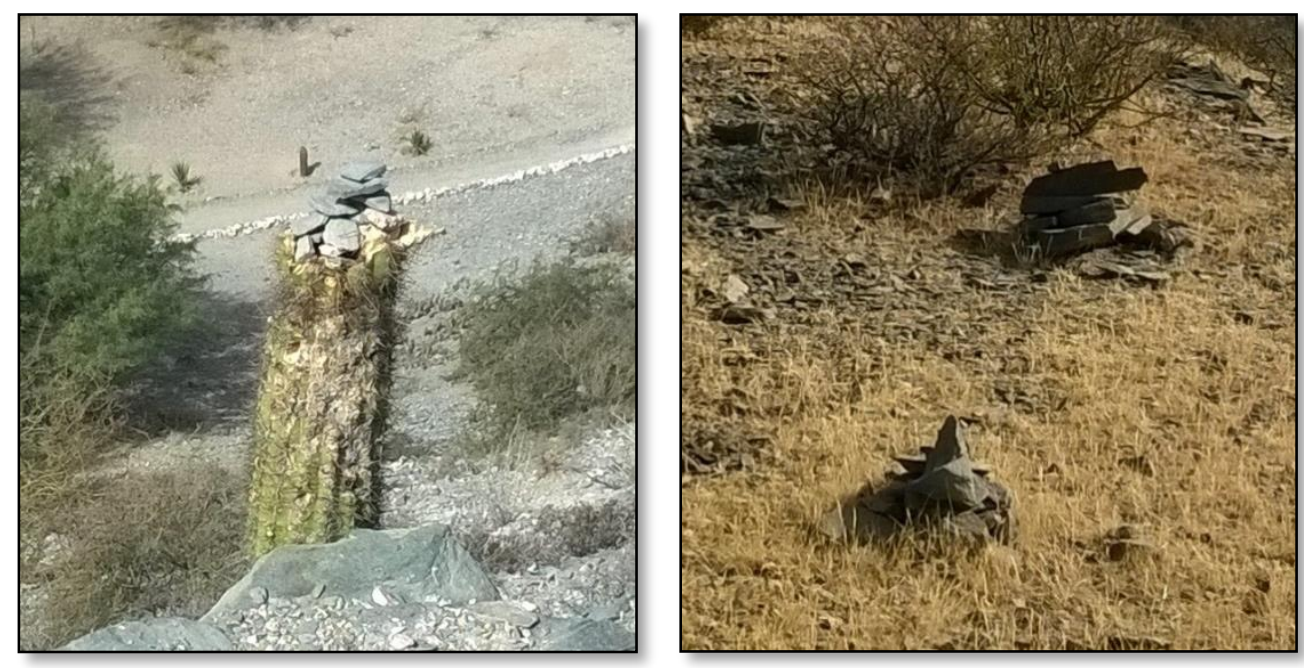

Figura 52 e 53 - Imagens exemplificando a presença de huancas nos caminhos de Las Mojarras.

Estas mesmas huancas podem ser observadas em diversos locais, inclusive dentro da cidade de Tafí del Valle. Em um terreno conquistado pela comunidade indígena, havia diversas huancas demarcando os seus limites.

\subsection{2 - Área 2: O sítio arqueológico Rincón Chico}

Ao ocidente do rio Santa Maria, em outro ponto alto da serra, foi fundado outro povoado indígena, próximo ao de Las Mojarras. Este centro povoado é conhecido como Rincón Chico. Localizado a Sudoeste do vale, a 5 km da cidade de Santa María, destacase o complexo arqueológico que conta com uma área de 500 ha. Representa um dos melhores exemplos conhecidos das distintas etapas do processo metalúrgico e de fabricação cerâmica, o qual apresentou, na sua época áurea, uma vasta população, indicada pela arquitetura e pelos abundantes restos de alimentação, pelas vasilhas para cozimento e consumo de alimentos e pelas evidências de locais funerários, localizados às bordas do âmbito habitacional (Tarragó 2007). O modelo de ocupação destacado para este tipo de povoado, que se aplica a Rincón Chico, caracteriza-se pelo uso da parte alta da 
serra como local de habitação para uma elite, e as outras facções da população ocupando as áreas de ladeira e aquelas dedicadas às tarefas produtivas dispersas (Cabrera 2015).

Considera-se que Rincón Chico assumiu a primazia dentro de um sistema de complementariedade funcional. Integraria as diversas instalações, congregando a obtenção direta de recursos básicos para a subsistência como instalações de cultivos intensos em locais com água permanente e instalações vinculadas ao pastoreio no interior da serra do Cajón (González e Tarragó 2000).

O desenvolvimento arquitetônico relaciona-se com as mudanças produzidas em nível social durante o período referente aos séculos IV-XV. Autores propõem que poderia haver um aumento da heterogeneidade e da desigualdade social. Esta situação implicaria uma modificação das relações sociais e segregação de setores residenciais, nas áreas com funções e atividades específicas (Tarragó e González 2004).

Ao mesmo tempo, parece ter conformado um laboratório de inovação metalúrgica e de produção cerâmica. Considerando-se os produtos finais, juntamente com as etapas previas à manufatura, é possível identificar diferentes áreas de atividade de produção, como áreas de trabalho e oficinas. É provável que, ao longo do tempo, foi sendo somada mão-de-obra de outras unidades vizinhas para a produção de cerâmica e metalurgia, hipótese que se levanta diante do intenso aumento da escala de produção. O material fragmentário permitiu identificar quatro grupos de componentes cerâmicos: a) estilo Santa Maria Tricolor, San José e Loma Rica; b) estilo Santa Maria Bicolor e Famabalasto Negro Gravado; c) estilo Santa Maria Tricolor, Famabalasto Negro Gravado e Santa Maria Negro sobre Vermelho; d) estilos Santa Maria Bicolor, Santa Maria Negro sobre Vermelho, Famabalasto Negro Gravado, recipientes com pé de compoteira e, em quantidade minoritária, estilos incaicos. A sucessão e a contemporaneidade destes estilos podem estar induzidas pela imprecisão das datações conseguidas. Há muitos outros povoados na zona que apresentam características parecidas de grupos de componentes, porém, à primeira vista, não se pode afirmar que compartilhem das mesmas trajetórias (Greco: 2014: 23).

A análise dos dados indica uma natureza mista de uso do espaço, onde o doméstico e a produção especializada provavelmente estiveram vinculados e entrelaçados de formas variadas. Além das oficinas, a atividade doméstica destaca-se pela produção simples para o funcionamento diário do povoado. Os restos ósseos indicam a presença de 
camelídeos com o predomínio do quarto traseiro e o quarto dianteiro, assim como partes do esqueleto axial. A presença de partes de animais de zonas rochosas e altas, como lhamas, vicunhas e roedores, em áreas baixas, permite pensar que foram caçados e transportados até o sítio (Tarragó 2007).

O centro povoado Rincón Chico apresenta grande complexidade interna quanto à distribuição, à relação e às características das construções. As construções superam o número de trezentos e correspondem a diferentes tipos como: moradias, recintos, praças, muros de contenção e plataformas, além de destacadas construções como um observatório astronômico formado por construções alinhadas que possuem características arquitetônicas muito particulares. Pelo estudo da arquitetura, é possível observar distintas classes de unidades. Sua combinação, sua densidade e sua distribuição permitiram discriminar doze setores com características específicas (Reynoso 2005).

O complexo Rincón Chico é considerado como centro povoado de primeira ordem em nível regional. Apresenta um padrão de assentamento dividido em três grandes áreas: a) um povoado conglomerado com um mínimo de 365 estruturas, localizado na serra e nas ladeiras de um esporão rochoso da serra do Cajón; b) 26 estruturas dispersas com vestígios de recintos habitacionais, localizadas no cone aluvial da vertente oriental da serra do Cajón; c) áreas de enterramentos, de circulação e atividades específicas, como agricultura e canteiros localizadas em conjuntos construtivos e vinculados à produção doméstica e artesanal (Greco e Cabrera 2009).

A partir da topografia do lugar de assentamento e da distinção dessas unidades se propôs a possibilidade de um padrão de assentamento hierarquizado. Destacam-se na serra construções que foram identificadas com: a) um possível fim de defesas; b) bairros residenciais especiais e espaços públicos nas partes mais altas; c) uma área cerimonial com edifícios singulares; e d) um povoado ao sul e ao pé da serra onde se concentram as unidades residenciais, separadas das áreas cerimoniais e dos cemitérios (Reynoso 2005).

Nos setores mais altos, destacam-se construções e estruturas com rochas de cores variadas que, possivelmente, representam um refinamento e uma busca por um estilo arquitetônico e decorativo específico. Estas construções aparecem associadas ao espaço residencial, principalmente na zona dos picos da serra relacionados com o uso das elites, destacando-se uma construção com pegmatito rosado, chamada "Casa Rosada", um recinto com parede de quartzo branco, chamado "Casa Branca" e outro construído com 
lascas cinzas selecionadas, chamado "Casa Plomiza". Outra construção destacada é um setor chamado "Quebrada del Puma"27, que apresenta uma organização espacial de estruturas alinhadas, todas utilizando rochas intencionalmente dispostas visando um efeito decorativo. Este alinhamento está relacionado com fenômenos astronômicos, sendo um possível observatório (Greco e Cabrera 2009).

As datações radio carbônicas indicam uma ocupação de ao menos setecentos anos, entre o século IX d.C. e a época do contato hispânico. O grupo arquitetônico recorrente está constituído por um recinto quadrado e estruturas anexas na sua periferia. Os recintos são construções semi-subterrâneas, sendo grandes espaços cobertos que se apoiam em muros perimetrais e um espaço aberto central. O contorno de cada conjunto inclui espaços externos, que parecem ter sido utilizados como locais de trabalho (Tarragó 2007).

Já os conjuntos construtivos no baixo Rincón Chico compõem-se de grandes recintos quadrangulares e estruturas menores anexadas, também quadrangulares ou circulares, separadas por espaços com ausência de construções. Estas estruturas podem ser divididas em duas classes: aquelas mais próximas ao conglomerado principal de Rincón Chico e outra que apenas se constitui de estruturas anexas quadrangulares (Greco e Cabrera 2009; Cabrera 2015).

\footnotetext{
${ }^{27}$ Este tipo de decoração foi comparado aos descritos em Las Mojarras, visto anteriormente.
} 


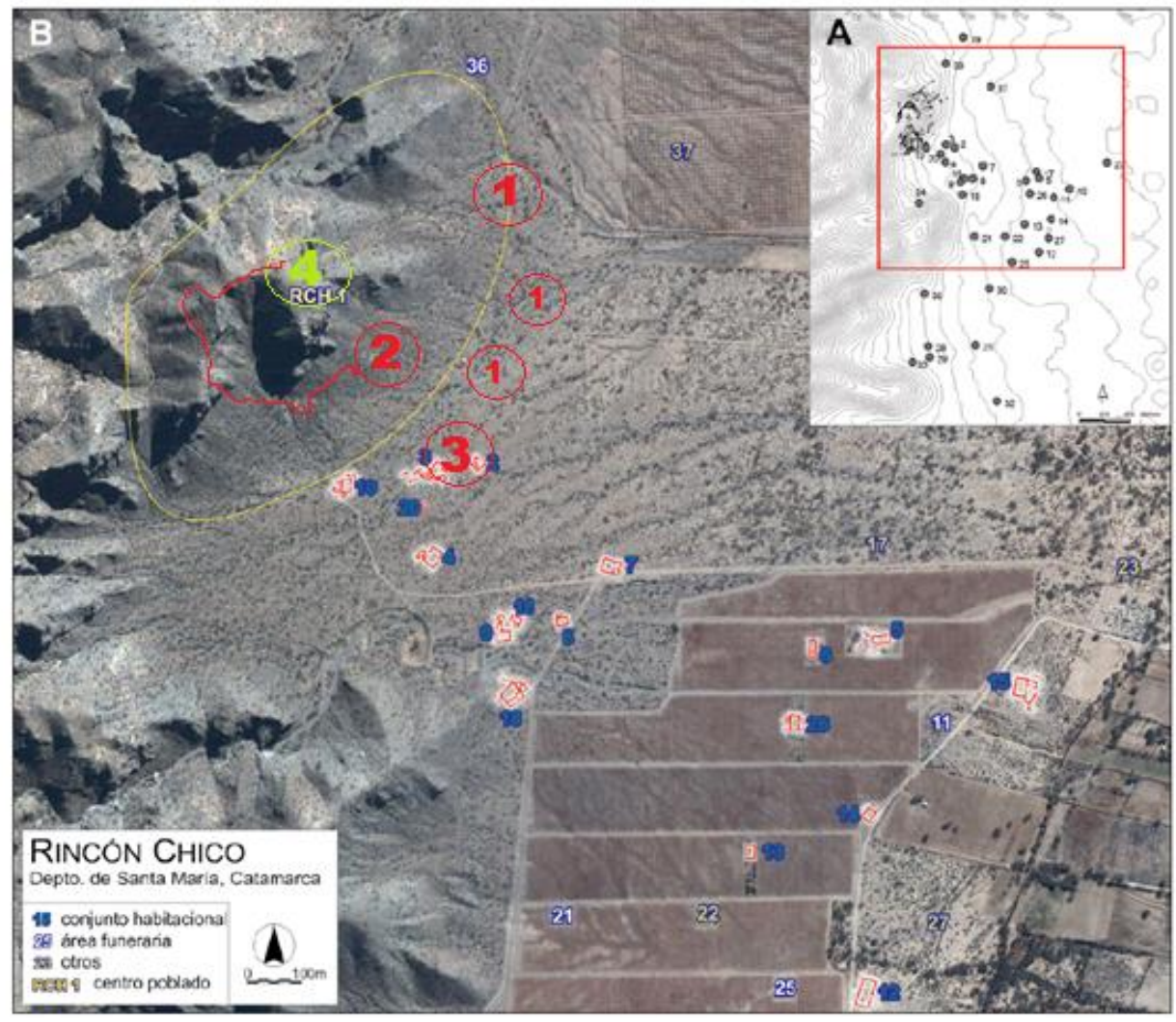

Figura 54 - Imagem indicando os sítios identificados do complexo Rincón Chico. Adaptado de Greco (2014: 21).

Como se faz visível no mapa anterior, alguns bairros de Santa María estão próximos ao complexo Rincón Chico, inclusive, nas proximidades, encontra-se a casa de Guadalupe. A área que corresponde ao baixo Rincón Chico é uma zona que ainda oferece uma série de recursos para a população atual, por isso é comum que as pessoas próximas façam viagens cotidianas em busca desses recursos, enquanto as áreas mais altas de Rincón Chico são acessadas esporadicamente com o fim de fazer passeios e piqueniques.

As atividades de captação de recursos são feitas de forma integrada, buscando acessar o maior número de recursos possíveis durante uma mesma viagem da forma que Binford $(1978 ; 1980)$ destaca nas saídas logísticas. Guadalupe coleta vários produtos: como pedras, flores, madeira, diversos tipos de galhos, entre outros; ao mesmo tempo, também maneja a paisagem, limpando algumas plantas que considera desnecessárias durante os caminhos, ou "reconstruindo" certas partes das ruínas, que considera importantes. Assim, Guadalupe faz várias paradas cobrindo toda uma área, que coincide com a parte baixa do complexo Rincón Chico, onde estavam as instalações produtivas. 
A primeira (atividade destacada no mapa pelo número 1 na cor vermelha), corresponde ao setor mais ao Norte do complexo Rincón Chico, na planície aluvial. Nesta zona, existe um bosque de alfarrobarias, essas plantas são utilizadas como fonte de lenha para o fogo da cozinha. Tradicionalmente as cozinhas são externas nesta zona, por isso algumas pessoas, como Guadalupe, fazem viagens cotidianamente para buscar lenha. No processo de cortar lenha, Guadalupe escolhe vários ramos de diferentes árvores e juntaos em um mesmo lugar. Depois, no chão, coleta pequenos galhos já secos e incorpora-os ao monte que havia feito.

Enquanto se está procurando por bons galhos para cortar e fazer lenha, é possível ver que outra pessoa também esteve juntando lenha e pedras no local, pois há um conjunto de galhos junto a algumas rochas, bem amarrados, posicionados em um canto próximo à maior rocha que contém vários orifícios de morteiro. Esse conjunto de galhos é respeitado por Guadalupe que o identifica, mas nem se aproxima.

Depois, deixa-se essa zona e dirige-se à serra. No caminho, todos os galhos que são considerados apropriados são cortados e acomodados de forma a serem encontrados no trajeto de volta. Ao deixar a planície e subir um pouco mais a ladeira da serra, começam a se fazer visíveis diversas ruínas das construções do complexo Rincón Chico.

Guadalupe conhece os caminhos por entre os recintos, vai caminhando sobre os espessos muros e segue um recorrido. Ela identifica os recintos, as paredes, as entradas e os trajetos ao redor dos recintos. Guadalupe diz identificar a técnica de produção desses muros, considera as "paredes bem-feitas e a pedra bem cortada", e mostra como, em alguns lugares, os muros são duplos e como algum deles tem um tipo de argamassa. Ela se questiona sobre as ruínas, se eram casas de moradia, como seria a disposição dos cômodos. Diz que gostaria de poder saber como as pessoas viviam ali, saber como eram essas pessoas, se eram iguais a ela ou muito diferentes.

Guadalupe conhece toda a disposição arquitetônica da ladeira. Enquanto caminha, ela indica o que existe para um lado ou para o outro, inclusive fala das construções que ficam nas áreas mais altas. Segundo ela, a subida para essas construções no topo da serra não é pela ladeira, mas se faria contornando a serra mais ao Sul pela parte mais baixa e fácil de subir (o trajeto aproximado é destacado no mapa pela linha de cor vermelha). Ela conta que não acessa o topo da serra para buscar recursos e que as pessoas vão para passear (área de viagens esporádicas indicada no mapa pelo número 4 na cor verde claro). 


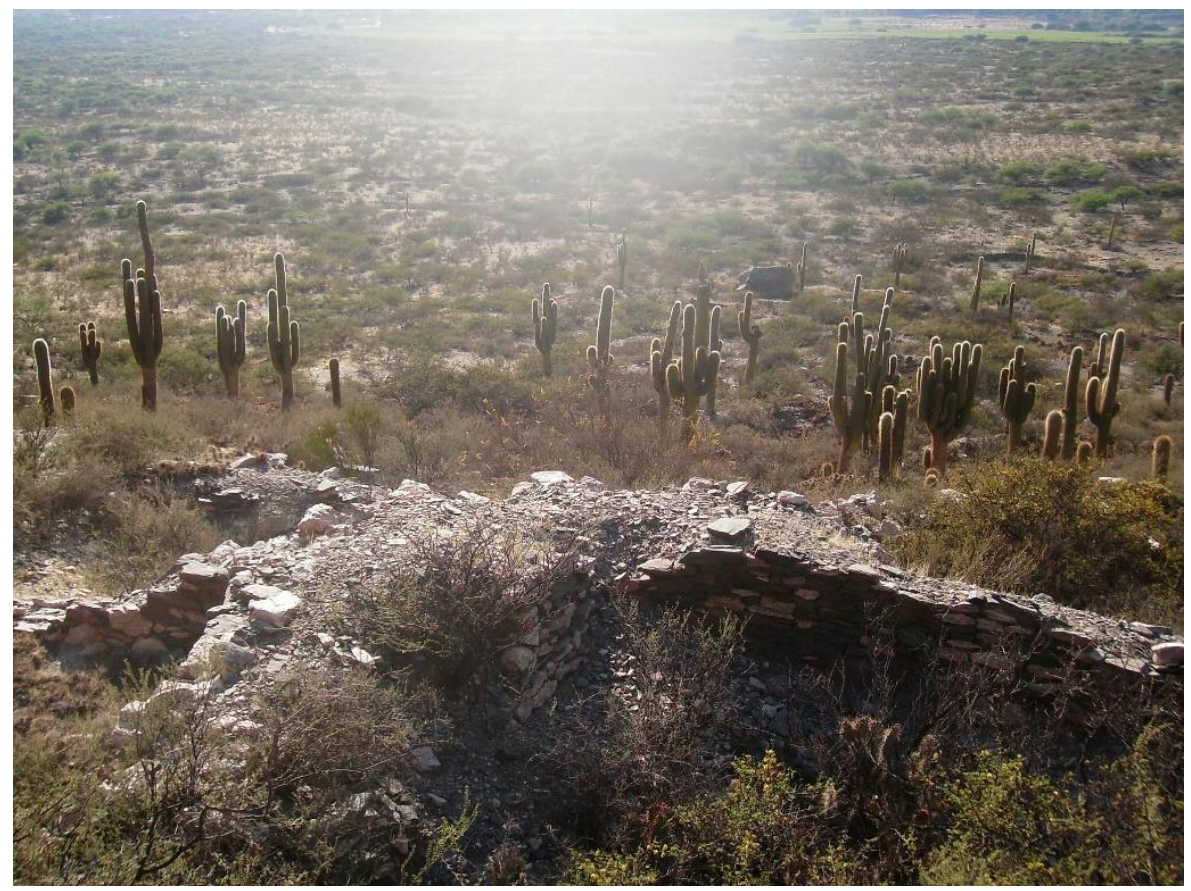

Figura 55 - Imagem indicando a presença de construções em Rincón Chico indicadas por Guadalupe.

Guadalupe percorre as ruínas e indica, nos muros que ainda são visíveis, como ela gostaria de fazer as paredes da cozinha que está em construção em sua casa. Muitas pessoas da região utilizam as rochas dessas ruínas, principalmente as grandes lascas, para fazer as construções modernas, porém isso não é generalizado, muitos - como Guadalupe e Dom Vicêncio - não se sentem à vontade, utilizando materiais de construções pretéritas em moradias atuais. Porém, ao que parece, não há problema em reutilizar as ruínas no local onde as construções estão dispostas, assim são utilizadas para diversos fins.

De volta à parte da planície aluvial, pela qual estendem-se as áreas produtivas do complexo Rincón Chico (destacada no mapa com o número 3 na cor vermelha), podem ser identificadas várias construções e reconstruções com as rochas das antigas ruínas, que hoje são utilizadas como currais temporários e pequenos diques para manter a água por mais tempo, que estão localizados na planície próximo ao caminho de descida da água da serra. De tanto uso e de tanto manter água por mais tempo nesta zona tão árida, a terra dentro das barragens tem uma aparência diferente. A cor diferenciada distingue-se da areia branca que recobre todo o vale, dentro, entre as pedras que formam as paredes, uma sutil vegetação mais parecida a musgos recobre alguns centímetros. 
Para a população local, esta zona mais baixa é uma área de currais, os quais consideram muito antigos. Por isso, mesmo aqueles que não utilizam os currais, ao passarem pelo lugar vão recolocando as pedras que estão soltas e limpando as áreas internas dos galhos (que Guadalupe junta para levar como lenha). Todo este complexo arqueológico suscita diversas informações para Guadalupe que, inclusive, sente-se identificada com as ruínas, por conta do estilo de construção e da proximidade de seu local de moradia.

Nas áreas próximas às ruinas de Rincón Chico, também se destaca a presença constante de huancas. Outra questão a se destacar sobre esta área é a presença de manifestações para a Pachamama, associadas a registros arqueológicos. Por exemplo, próximo a várias rochas, com a presença de orifícios, conhecidas como morteiros públicos, havia um conjunto com rochas de quartzo brancas acomodadas com galhos dispostos em uma posição peculiar. Também presenciaram outras manifestações muito parecidas em vários locais dos campos e caminhos.
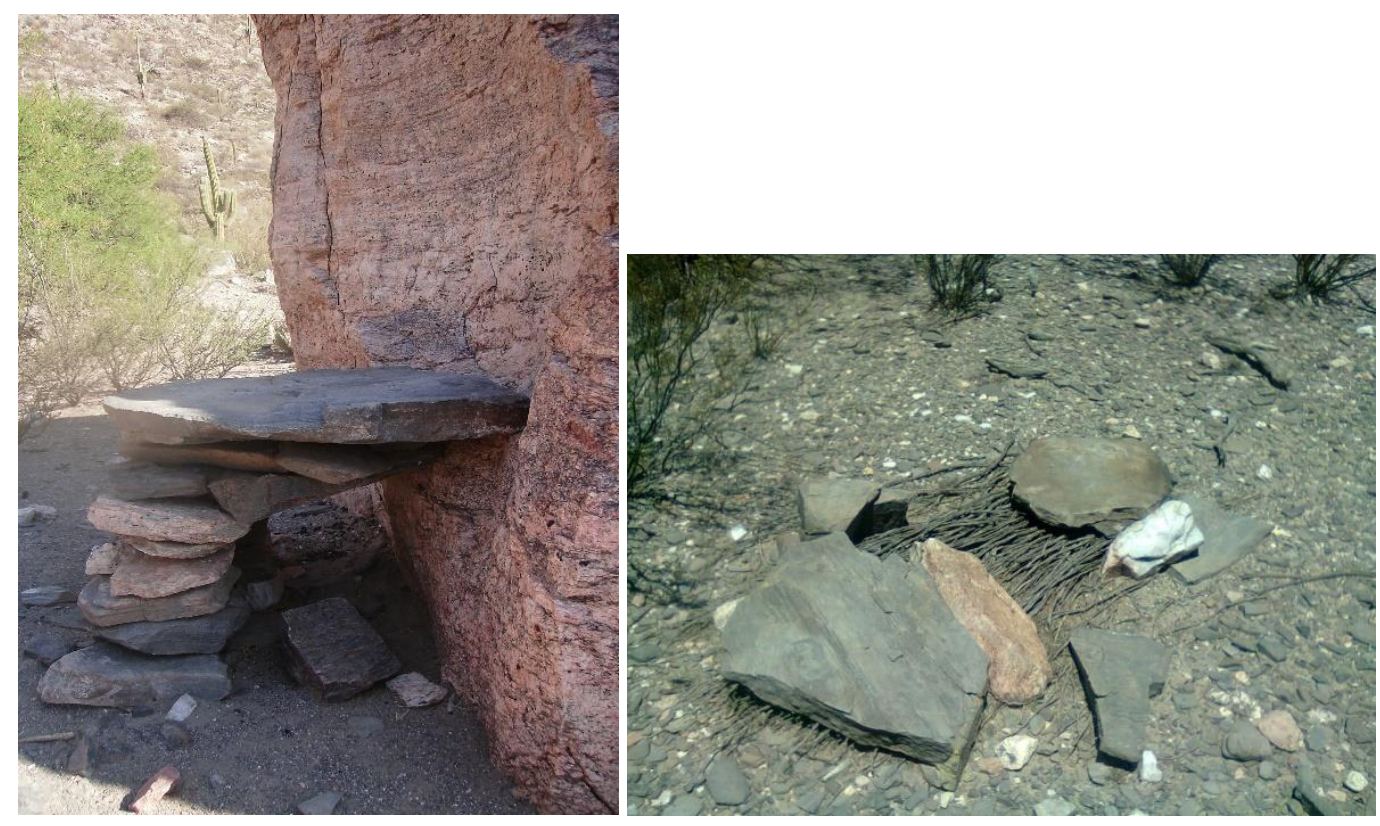

Figura 56 - Imagens indicando a presença de símbolos na paisagem. A primeira imagem representa uma huanca associada a um morteiro comunitário arqueológico. A segunda imagem representa uma huanca para a Pachamama nas próximidades. 
Esta área da parte baixa do complexo Rincón Chico é indicada pelas análises arqueológicas como uma área de produção e de moradia daqueles que exerciam as atividades no local (Greco e Cabrera 2009; Cabrera 2015). Atualmente, a diferença do topo da serra que é utilizado apenas para passeios, esta área continua sendo um local de captação de recursos e produtos, assim como as ruínas são utilizadas para manterem os animais nos períodos mais férteis que podem ficar próximos aos vales. As ruínas arqueológicas acompanham os recursos e, muitas vezes, são marcadores simbólicos, como as grandes rochas com os morteiros públicos.

\subsection{3 - Área 3: sítios na área da queda de água da Virgen Perida}

A aproximadamente $6 \mathrm{~km}$ de Las Mojarras e 3,5 km de Rincón Chico existe um local de água não perene. O local conta com uma queda de água e, ao redor, existem vários sítios arqueológicos (alguns reutilizados), juntamente a processos de ocupação mais atual. A área pode ser acessada contornando-se a serra em direção ao Norte, descendo-se o complexo Rincón Chico ou caminhando a Sudoeste desde Las Mojarras, acessando o "fundo" do estreito vale entre as serras, chamado Quebrada de La Virgen Perdida, depois de passar por uma queda de água com o mesmo nome da Quebrada.

Ojo de Agua, Agua Cavada, Dom Clemente e Los Pozos são os primeiros sítios arqueológicos que se destacam logo nas proximidades da queda de água, logo se atravessa o sítio Virgen Perdida 2 e o Virgen Perdida 1 (localizado sobre o cordão montanhoso, no limite Sul da Quebrada). Ojo de Agua e Agua Cavada estão localizados nas porções inferiores da serra, associados a vertentes de água (Nastri et al 2002). 


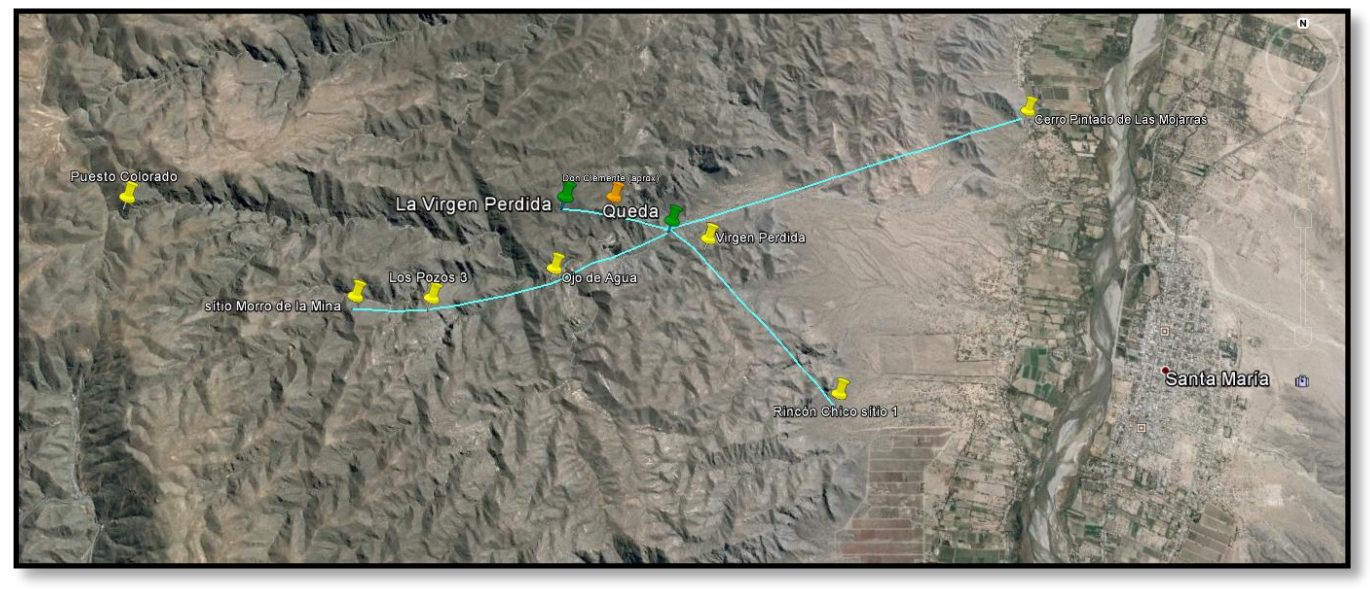

Figura 57 - Imagem referenciando as localizações no mapa. A figura indica os locais referentes a Las Mojarras, Rincón Chico em relação ao local de La Virgem Perdida. Os pontos da cor amarela indicam os sítios arqueológicos conhecidos na zona. O ponto na cor verde indica o local onde se localiza o calvário da Virgem Perdida e o da cor laranja destaca a queda d'água subsequente. As linhas na cor azul claro indicam os caminhos (em linha reta, sem levar em conta o relevo).

Ojo de Agua é um sítio localizado muito próximo à queda de água da Quebrada de la Virgen Perdida. Este sítio apresenta apenas seis recintos, que variam em tamanho de 3 metros de diâmetros a 7 metros por 22 metros, e apresenta a presença de fragmentos cerâmicos $^{28}$ (Nastri 2001).

Dom Clemente e Los Pozos encontram-se sobre a ladeira e em cima da serra. $\mathrm{Na}$ figura anterior, destaca-se Los Pozos 3, o qual apresenta três estruturas apoiadas sobre um fundamento rochoso (com vários indícios de perfurações de morteiro). Existem recintos a uma distância de aproximadamente 250 metros entre eles, o primeiro, localizado ao Norte, está construído sobre um afloramento rochoso apresentando 8 metros de diâmetro, contido no seu interior, sobre o afloramento rochoso, encontra-se outro recinto circular de 2 metros de diâmetro e com entrada. Atualmente o que é visível do sítio são as grandes lascas que serviram de sustentação para os muros. O outro recinto apresenta formato circular de 15 metros de diâmetro e está dividido ao meio, formando dois sub-recintos. Também ele está apoiado sobre outro afloramento rochoso (Nastri et al 2002).

\footnotetext{
${ }^{28}$ Destaca-se a presença de fragmentos nos estilos Santa María Tricolor e Bicolor, Famabalasto Negro Gravado e fragmentos toscos e grossos.
} 


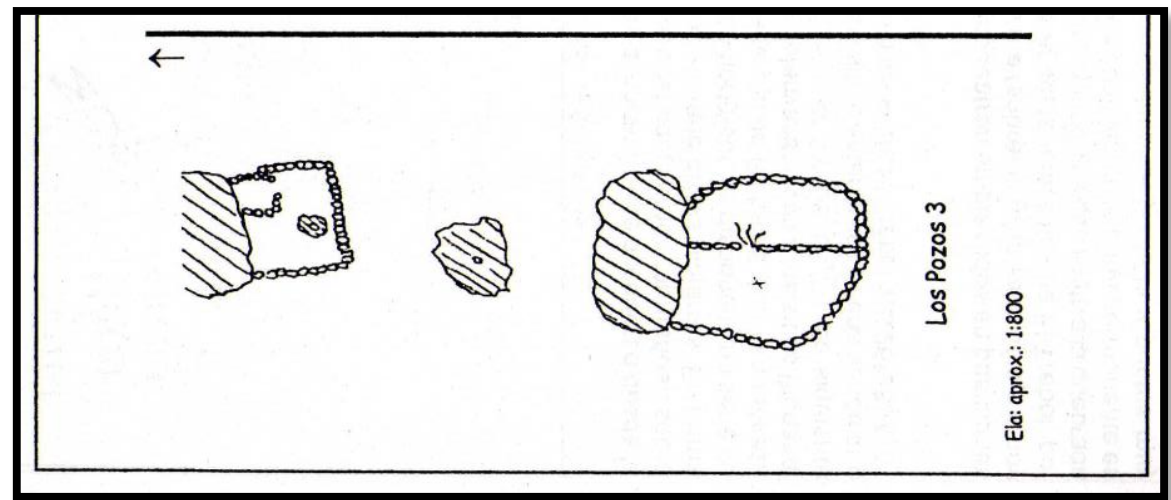

Figura 58 - Representando o esquema da estrutura do posto no sítio arqueológico Los Pozos 3. Adaptado de Nastri et al: 2001: 424.

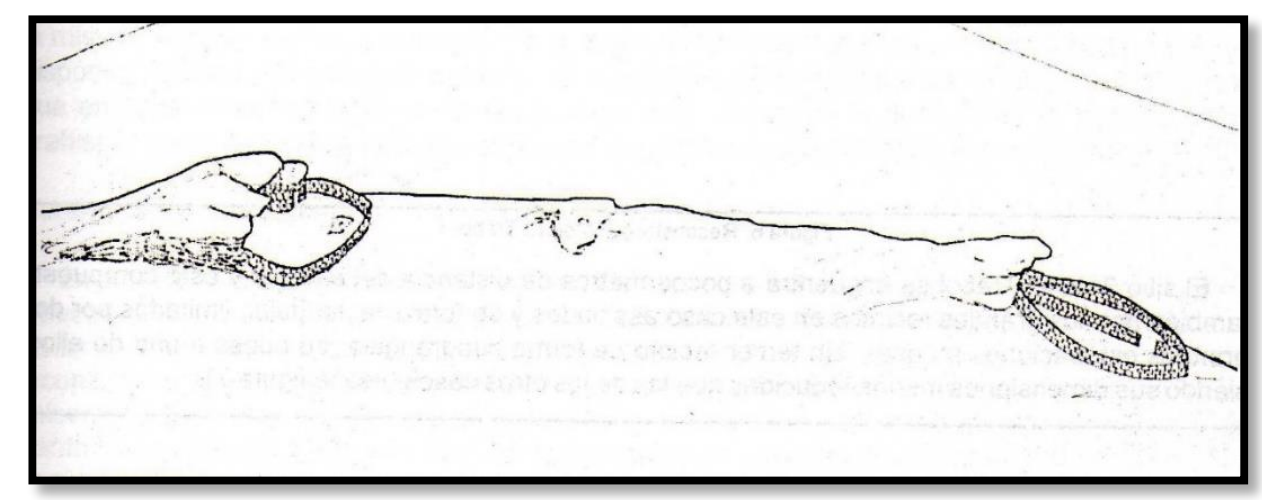

Figura 59 - Imagem representando a possível reconstrução do sítio arqueológico Los Pozos 3. Adaptado de Nastri et al: 2002: 425.

Neste mesmo estilo, encontra-se o sítio Agua Cavada. À primeira vista, o registro arqueológico deste sítio é muito similar ao dos outros dois sítios indicados anteriormente - Los Pozos e Agua Cavada -. Atualmente são visíveis as grandes lascas que permaneceram da sustentação dos muros em pé, indicando a presença de grandes recintos incorporando um pequeno recinto ao lado ou no interior dos maiores (Nastri et al 2002). Acredita-se que foram utilizados como currais e os pequenos recintos corresponderiam ao local de descanso do pastor, assim como indicado no curral de altura, presente em El Carmen, destacado no capítulo anterior. 
O sítio Agua Cavada consta de dois grandes recintos retangulares de 6 metros por 10 metros. As dimensões dos recintos estão adaptadas ao terreno. Junto a um afloramento rochoso, existe um pequeno recinto de 3 metros de diâmetro com entrada. Este sítio está localizado nas proximidades de um posto de uso até os dias atuais que, possivelmente, reponde à mesma dinâmica apresentada nas informações arqueológicas.

Localizado em cima da queda de água da Virgen Perdida, encontra-se outro sítio arqueológico denominado Don Clemente. Este sítio de altura semelhante à daqueles descritos anteriormente, apresenta quatro recintos e está muito próximo ao sitio Ojo de Agua (a apenas $1 \mathrm{~km}$ ). Sobre a ladeira que separa estes dois locais, existem diversos recintos isolados.

Nas proximidades, encontra-se outro sítio arqueológico designado como "Virgen Perdida. Está localizado na cima da ladeira a aproximadamente 500 metros da queda de água da Virgen Perdida (também está próximo ao complexo Rincón Chico, o que faz que, muitas vezes, seja visto como em relação com esse grande centro povoado). Consta de recintos pequenos e médios, sendo quatro circulares e seis retangulares, além da presença de vários muros (de mais de 2 metros) que foram considerados de caráter defensivo. As construções, formadas por lascas rochosas posicionadas na vertical, indicam que foi aproveitado material rochoso das redondezas. Nos muros destaca-se a presença de decoração pelo posicionamento de blocos rochosos de quartzo branco entre blocos de cor chumbo (assim como destacado em Las Mojarras e Rincón Chico). Em alguns, esses blocos brancos são maiores, em outros, o tamanho das rochas é menor (Nastri 2001).

De acordo com as nomenclaturas e designações que são feitas na arqueologia referentes aos vales Calchaquíes, esses sítios são todos designados como postos de atividades específicas. Considera-se que não se trata se locais de moradia pois não indicam a presença de atividades cotidianas que não sejam aquelas específicas (Nastri 2001). Neste caso, existem algumas discussões sobre as distinções entre instalações agrícolas, pastoris e aquelas que são consideradas defensivas. No caso, não cabe a este trabalho questionar essas nomenclaturas, apenas levantar hipóteses sobre possíveis pontos de vista.

Sendo assim, algo que parece ficar muito claro na descrição destes locais arqueológicos na relação com o uso dessas mesmas áreas para a captação de recursos é a 
presença constante do pastoreio de altura e a relação com as fontes de água não perenes desta zona específica.

Esta área é importante para a população por diversas questões. Primeiramente, esta zona da Quebrada de la Virgen Perdida é muito utilizada entre os pastores porque existem locais com água não perene e também pastagens. Assim, tanto Dom Vicêncio e seus filhos que moram em Las Mojarras, como o irmão de Guadalupe que habita no interior da serra acessam essa Quebrada em busca de recursos. Como já foi colocado nos capítulos anteriores, os pastores têm por hábito levar os animais até determinados locais e, muitas vezes, ausentarem-se. Ao mesmo tempo, raramente prendem os animais dentro de currais, portanto, sem um trabalho mais detalhado de identificação de estrume de animal nos currais em grande quantidade, não é possível assumir se há a utilização de antigos currais.

Estes locais são procurados pelos pastores pelos recursos que oferecem em relação ao pastoreio. Já, as mulheres fazem vários passeios até a queda de água da Virgen Perdida, no mesmo modelo de passeio que se faz ao Pucará, porém como é um trajeto mais longo, as crianças pequenas no geral não acompanham. Durante o percurso, são identificados vários locais que são sítios arqueológicos, no geral, fala-se de currais e casas de acordo com a altura. Sobre os locais com água não perene, existem várias histórias e interpretações, como rochas em formatos específicos e designações que se assemelham aos simbolismos referentes à água. Esta zona é considerada um lugar público que as pessoas devem acessar com facilidade. As mulheres vão pelos caminhos da planície e acessam a Quebrada de La Virgen Perdida, os pastores acessam pelo alto das serras por uma série de caminhos conectados. 


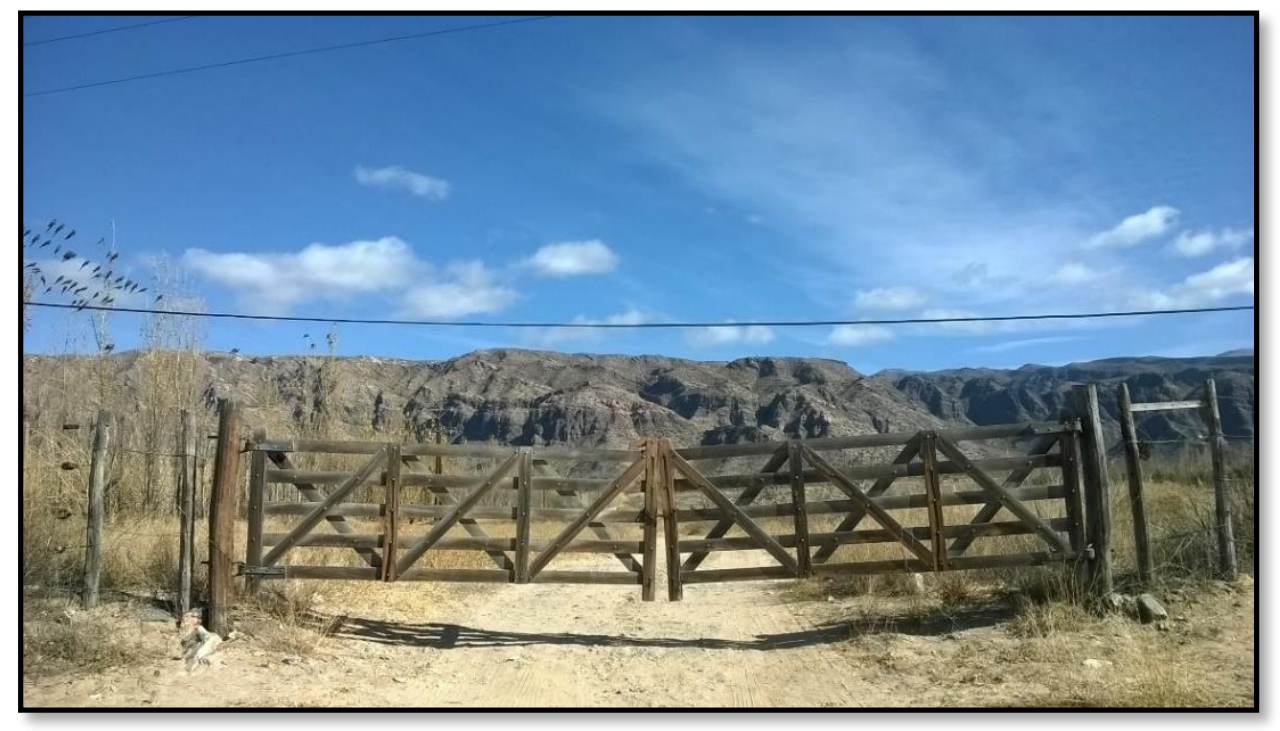

Figura 60 - Um dos caminhos em direção à Virgen Perdida.

O local também é importante pela presença de um calvário com uma virgem. Em um dos passeios com as filhas de Dom Vicêncio, elas indicavam a grande preocupação em não poder atravessar as porteiras e os campos que conectam até a Virgen perdida, pois isso estaria também impossibilitando os pastores de acessar esse local e poderia implicar na perda de um rebanho inteiro de animais.

Portanto, ainda quando estes locais com a presença de possíveis currais pretéritos não estejam sendo reutilizados, o lugar continua tendo importância na captação dos recursos que oferece, implicando um contínuo uso do espaço pelos diversos grupos. Para a população local, a existência dessas ruínas associadas ao local de água da Virgen Perdida é atestado de que foram utilizadas para o trabalho pastoril, assim como o lugar ainda é utilizado para levar os animais, tanto entre aqueles que estão na serra como entre os que estão no vale. O simbolismo deste lugar está relacionado ao universo do pastoreio, aos processos de movimento dos pastores em busca de água e pastagens quando os vales já não estão férteis o suficiente para sustentar os rebanhos. O lugar é muito conhecido, sendo que as pessoas do lugar, como Dona Maria, afirmam que o seu pai já utilizava os recursos da Virgen Perdida.

A interação dos pastores nesta área da Virgen Perdida com as ruínas arqueológicas, diferencia-se da interação que foi observada para nas outras duas áreas. Nas áreas altas dos centros povoados - Rincón Chico e Las Mojarras - a interação com 
as ruinas é de passeio e apreciação, as pessoas vão para fazer caminhadas, piqueniques, apreciar as construções e a vista do vale que esses lugares proporcionam, explanando as possibilidades do passado e a permanência no presente. As áreas baixas destes centros povoados são áreas de captação, onde estas pessoas vivem e recorrem para coletar os recursos necessários que as áreas oferecem. Esta última área, referente à Quebrada de la Virgen Perdida, é uma área que implica duas percepções: a) para as mulheres responde ao propósito de passeio, acessando o calvário e a queda d'água, fazendo o caminho inclusive com crianças; b) para os homens é um local de pastoreio, acessam o lado mais alto desde caminhos que provêm do interior da serra e os pontos mais baixos, desde os caminhos do vale.

A relação dos pastores com as ruínas nas áreas de serra e em contexto pastoril é diferente daquela observada pelas mulheres. Outra questão é a diferença entre ruínas que são constantemente reutilizadas e aquelas que não o são. Estas últimas provocam temor e desconfiança entre os pastores, principalmente porque entre as ruínas, era possível encontrar metais e peças que podiam ser vendidas por altos preços. Essa prática era e é vista entre a população destes vales como um desrespeito às pessoas que ali viveram e que ali "descansam". Relatos comuns de pastores, como Dom Vicêncio, indicam esta distinção. Dom Vicêncio sempre afirma que, apesar de que, quando criança, ele tenha andando por entre ruínas por curiosidade, nunca se atreveu a mexer nem retirar nada dos locais, pois "é um homem justo".

Desta forma, na paisagem, estão impressas as interações que ali aconteceram, e essas impressões têm efeitos diferentes de acordo com a atividade que se leva a cabo nos diferentes locais. Inclusive, um mesmo lugar pode implicar sensações diferentes para diferentes pessoas. Mesmo dentro do mesmo grupo, são feitas distinções de apreensão dessa paisagem a partir de gênero, status, faixa etária, atividade econômica etc. Desta forma, as interações comportamentais implícitas na paisagem são materializadas no presente e podem ser compreendidas a partir de três dimensões: 1) a dimensão formal, que corresponde às características físicas do contexto; 2) a dimensão relacional, que corresponde às conexões interativas (econômica, social, política e ritual) que acontecem; e 3) a dimensão histórica, que descreve a progressão da paisagem apreendida, resultante dos seus sucessivos usos (Zedeño et al 2009). 
Estas três dimensões permitem identificar e descrever o contexto da paisagem. A apreensão e o modo de uso do espaço são indicativos da ocupação (ou ocupações) que ali ocorre, são referentes de identidade. A partir das trajetórias dos grupos, é possível reconstruir a história das pessoas e dos materiais em uma paisagem, e dar suas diretrizes identitárias (Zedeño 1997).

Portanto, a paisagem é dinâmica porque é interpretativa e existe no tempo, o qual varia e representa as construções multidimensionais, entre estruturas historicamente determinadas e processos contingenciais. A paisagem é entendida como reflexo do comportamento humano em um ambiente determinado, as ações, as escolhas e as modificações do espaço natural. Esta paisagem é o resultado da transformação e da exploração do meio, tanto no âmbito da subsistência, quanto no âmbito simbólico e ritual. É um produto da co-evolução de uma sociedade e de um meio ao longo dos anos, um sistema não linear de evolução governada por transições abruptas e descontinuidades históricas (Layton e Ucko 1999). 


\section{Reflexões Finais}

Umas das questões centrais desta tese é entender o sistema pastoril de Santa María e as múltiplas perspectivas que esse sistema poderia levantar sobre a relação entre humanos, animais e o meio que os rodeia, em busca das implicações materiais resultantes desse comportamento. Por sua vez, para a compreensão da percepção do meio pelos pastores de Santa María chegou-se ao tema da paisagem, suas interpretações e significados.

Diante disso, esta tese foi construída de forma a introduzir o leitor no universo do pastoreio, buscando cobrir aquelas dimensões consideradas mais relevantes. Partiu-se das questões mais gerais que caracterizam o vale de Santa María, introduzindo as características ambientais, topográficas e a história humana da região a fim de se compreender a complexidade ambiental, econômica e social da região que, por sua vez, afetam diretamente os coletivos humanos em relação ao seu universo material.

Logo, identificaram-se as características do sistema pastoril vigente em Santa María. Trata-se de um tipo de pastoreio tradicional focado em caprinos (cabras e/ou ovelhas) e burros, com o uso de pastagens naturais e movimentos sazonais para o melhor aproveitamento das diferentes zonas ecológicas. Como o animal e as pastagens são elementos centrais na discussão pastoril, discorrer sobre o processo de domesticação e a relação entre humanos e animais é fundamental para a compreensão de todo o sistema, o que permitiu entender muitos dos hábitos de mobilidade desses pastores, que é um dos pontos centrais da discussão.

Seguindo esta discussão, compreender a mobilidade permitiu definir as distintas áreas de atividades e a constituição do território pastoril a partir de caminhos, lugares e recursos hídricos e pastagens. Sendo assim, as estruturas construídas têm relação com a própria divisão do trabalho, entre a casa residencial onde permanecem todo o ano as mulheres, crianças e os animais pequenos do rebanho, e os caminhos pastoris no interior das serras, que são as áreas dos pastores e dos animais adultos do rebanho.

A visão sobre a paisagem dos pastores é diferente, pois a relação destas pessoas com os animais e o meio à volta é complexa, os animais do rebanho são mais do que 
objeto de mercadoria, eles representam e incorporam questões amplas. Neste contexto, tanto os humanos como os animais apresentam agência, onde cada um está influenciando e transformando a relação com o meio.

Todas estas questões deram o contraponto da discussão sobre como os caminhos pastoris conectam áreas de interesse dos pastores. No processo de caminhar pelos caminhos, estes se estruturam e são reconhecidos a partir de marcos físicos e ideológicos dessa paisagem pastoril. Os caminhos pastoris que recortam todo o vale e as serras de Santa María conectam áreas de moradia a locais de água e pastagem, definindo marcos de uma ocupação reiterada por milhares de anos. Esta ocupação reiterada das mesmas áreas produz um registro arqueológico multitemporal. Desta forma, é possível reconhecer os lugares a partir dos traços particulares que constituem essa paisagem apreendida pelos pastores atuais, porém também é possível destacar o uso e a ocupação dos mesmos espaços desde tempos pretéritos.

\section{1 - Sobre as áreas de captação e de maior probabilidade arqueológica}

Identificar populações nômades e o tipo de pastoreio é um desafio para a arqueologia, ainda mais quando se trata de ambientes áridos e de difícil acesso, como é o caso das montanhas andinas. Porém, acredito que através de dados etnoarqueológicos é possível estabelecer áreas de maior potencial arqueológico para identificar e/ou presumir sobre esses comportamentos pastoris do passado.

Durante muitos anos as discussões na arqueologia centraram-se na visibilidade dos registros arqueológicos das populações nômades, principalmente entre aqueles grupos que não deixavam um registro facilmente identificável. A partir da década de 1990, houve um maior interesse em identificar os vestígios das populações pastoris nômades do passado, principalmente com foco na etnoarqueologia (ver Barnard e Wendrich 2008). Como existe uma grande variabilidade de formas e tipos de pastoreio, as questões centraram-se na distinção dos hábitos pastoris de populações específicas para então tentar traçar paralelos e relações com os registros do passado. Portanto, é necessário reconhecer as técnicas específicas para identificar e localizar os sítios resultantes do pastoreio. 
Arqueologicamente, a visibilidade dos registros dos nômades levanta alguns pontos, tanto pela sutileza dos sítios como pelas possíveis classificações errôneas. Nisto, a etnoarqueologia tem-se mostrado fundamental, identificando diferentes sistemas e várias formas de adaptação. Para tanto, existem algumas questões fundamentais a serem colocadas para uma maior compreensão dos pastores no contexto arqueológico (Anfinset 2014).

Em primeiro lugar, destaca-se a abordagem regional, considerando-se a busca por pastagens e a captação de recursos que ocorrem nos diversos locais. Dificilmente os grupos pastores se restringem a apenas um local, pois como vimos, nos capítulos desta tese, os pastores movimentam-se por uma área relativamente extensa em busca dos locais de água não perene, de pastagens férteis e de áreas de captação de diversos recursos (madeira, argila, mercados, escolas etc.).

Em segundo lugar, é importante ter uma visão do todo e ter em mente dados sobre a ocupação sazonal dos sítios. No caso dos pastores de Santa María, tende-se a construir uma casa residencial permanente, a qual poderia ser identificada arqueologicamente junto a outras construções de médio e curto prazo de permanência. Como há diversos tipos de pastoreio pelo mundo, os métodos tradicionais de registro de um sítio devem ser confrontados com análises regionais a fim de distinguir as ocupações a longo, médio e curto prazo, focando nas características que os sítios apresentam e nas relações de integração entre eles. Isto porque o registro do assentamento residencial pode ser semelhante ao de grupos sedentários e os assentamentos de curto prazo são difíceis de identificar.

Por fim, em terceiro lugar, coloca-se a questão da importância da água em zonas áridas e a sua oferta limitada, o que implica movimentos migratórios até os locais onde há fontes de água permanente em períodos de estiagem. Em outros casos, também se destaca a importância do estoque, porém este assunto não é tratado nesta tese, pois os dados sobre o comportamento de estocagem não foram observados etnograficamente.

Sobre a variabilidade dos modos de produção pastoril definiu-se um sistema pastoril tradicional com mobilidade sazonal, com rebanhos de animais adaptados à altitude que são mudados de locais para captar água e pastagens de acordo com o período do ano e a presença de movimentos longos durante as caravanas. Este sistema comporta o consumo e/ou produção de grãos, venda dos produtos primários e secundários do 
rebanho e a participação no mercado como uma estratégia dentro do funcionamento do sistema pastoril.

Este sistema pastoril beneficia-se da verticalidade andina, utilizando zonas ecológicas em diferentes altitudes, além do incremento do uso de mercados. $\mathrm{O}$ aproveitamento desses diferentes nichos a partir de movimentos sazonais ao longo do ciclo anual é o que permite que o sistema pastoril se perpetue no vale de Santa María. As condições climáticas deste vale aliadas à topografia definem um ambiente que vai do semi-árido ao árido, apresentando verões mais cálidos e chuvosos e invernos frios e secos.

Diante destas condições, os herbívoros terrestres destas zonas andinas exibem movimentos sazonais. Movimentam-se pelas áreas férteis ao longo do ano, permanecendo às margens dos vales nos períodos chuvosos do verão e, conforme avança o inverno, deslocam-se cada vez mais em direção ao interior das serras para alcançar as pastagens resistentes ao frio das zonas mais altas. Este padrão de mobilidade dos camelídeos é muito semelhante ao dos pastores que, como foi colocado, permanecem nos vales nos períodos chuvosos de verão e movimentam-se em direção ao interior das serras conforme a temporada de estiagem começa.

No pastoreio, o animal é o elemento central. Os humanos necessitam dos animais para ter um melhor aproveitamento dos elementos ambientais pois, principalmente nos meses de estiagem, os animais conseguem ter um melhor aproveitamento nutricional do que o ambiente proporciona e os humanos aproveitam os subprodutos desses animais. Por sua vez, o comportamento dos camelídeos é extremamente territorial, não tendo exigido do pastor muitos cuidados, principalmente no que se refere ao fechamento destes animais em currais ou áreas cercadas.

Atualmente em Santa María poucas famílias ainda criam lhamas. A maioria delas dedica-se à criação de cabras ou ovelhas resistentes à altitude. Estes animais apresentam comportamentos muito diferentes dos camelídeos andinos em relação aos movimentos alimentares e territoriais. Porém, o que se observa é a replicação do comportamento típico dos camelídeos entre rebanhos de outros tipos de ungulados.

Portanto, estas duas questões remetem ao comportamento dos camelídeos no pastoreio atual do vale de Santa María: a) os pastores continuam com uma mobilidade pastoril dividida entre verão nas áreas dos vales e inverno no alto das serras, b) os animais 
ficam sem a presença do pastor por alguns dias. Acredito que esta relação seja um marco distintivo que pode dar muitas informações sobre as áreas de maior potencial arqueológico, pois a replicação de um movimento pastoril de lhamas relaciona o sistema diretamente com as populações antes da influência europeia na região, apontando para uma paisagem marcada por rotas de pastoreio que ligam os vales às zonas altas das serras.

Este comportamento também explica uma questão diferencial do pastoreio andino. Os estudos sobre movimentos pastoris distinguiram os movimentos em dois tipos: a) mobilidade horizontal, movimento em estepes comportando áreas de mesma altitude; b) mobilidade vertical, movimento em áreas montanhosas com diferentes altitudes. A maioria dos casos de mobilidade pastoril vertical é definida pelo uso de pastagens de inverno nos vales e de pastagens no alto das serras no verão (Xiao et al 2015; Kradin 2015).

No vale de Santa María - e em outras regiões andinas (ver Ventura e Belardi 2001; Yacobaccio e Madera 2001; Aldenderfer 2016) - a mobilidade vertical é invertida, provavelmente as características áridas do ambiente andino aliadas às adaptações de fauna e flora fazem necessária essa movimentação entre áreas altas no inverno e a possibilidade da permanência nos vales durante o verão. Estas definições são fundamentais para estabelecer uma discussão com a teoria mundial sobre estudos pastoris, além de estabelecer condições claras para a formulação de um modelo etnoarqueológico para esta região.

No capítulo 4, tentou-se demonstrar em que consistem os caminhos dentro da conceitualialização da paisagem que esses pastores fazem. Primeiro, definiram-se algumas das características que constituem esses caminhos pastoris, sendo longos caminhos que se conformam pela junção de vários pequenos caminhos. Cada um desses pequenos caminhos é referente a uma atividade e ação específica. Desta forma, utilizouse como exemplo o caminho de pastoreio que Dom Yucra fazia, o qual conecta a casa atual de Dom Yucra a um caminho de altura. Assim, o caminho integra a casa atual deste senhor à antiga casa da sua mãe, à casa de sua filha, à casa de dois vizinhos, aos currais de uso atual e antigos, ao leito do rio e locais com diques que permitem fazer pequenos plantios, a um afloramento de argila, aos currais e locais de pastagens no alto das serras e finalmente a outros caminhos que levam a locais altos de Puna. 
Os caminhos principais são também lugares, porque são repositórios dessas diversas atividades e também de histórias e ações do passado. Desta forma, quando um dos pastores definia um lugar, este era indicado pelo processo de movimento até o determinado lugar. O movimento define o próprio lugar, integrando histórias, comportamento e a necessidade, nesses processos, de mobilidade. Assim, como repositórios e indicadores dos caminhos são definidos e identificados pelas pessoas do lugar, permitindo estabelecer um padrão tanto para o ritmo como para os indicadores desses caminhos/lugares.

Ao mesmo tempo, no capítulo 5, buscou-se demonstrar como caminhos e lugares também estão relacionados ao registro arqueológico do passado, porém por uma perspectiva própria dessas pessoas. Estes pastores estão em constante relação com os registros arqueológicos, que lhes são significativos dentro das suas próprias lógicas e não através da perspectiva acadêmica do que esses sítios arqueológicos representam.

A identidade com as ruínas da zona de Santa María dá-se pelos lugares nos quais estão erguidas. As áreas com recursos que foram importantes no passado continuam tendo importância para estes pastores da atualidade. Portanto, lugares como o Cerro Pintado e Rincón Chico continuam sendo expressivos pelos recursos que permitem cooptar. Sendo assim, as áreas baixas desses dois centros povoados, que provavelmente foram locais de moradia junto a áreas de trabalho no passado, continuam apresentando vantagens para estabelecer moradia para estes pastores, pois estão localizados no vale, muito próximos à subida da serra, permitindo fazer uso das áreas próximas ao rio quando estão férteis para plantio e para manter os animais na época do verão, além da proximidade dos bosques de alfarrobeira e do centro urbano, para serviços e produtos. Além do mais, as ruínas são importantes por causa das antigas construções, que ainda são utilizadas como currais e diques para manter a água, além do uso dos cardones que crescem entre as ruínas para alimentar o rebanho quando necessário.

Por sua vez, lugares como a Virgen Perdida, que apresenta uma fonte de água não perene, continuam tendo importância no que se refere ao pastoreio. A Virgen Perida é um lugar que os pastores podem acessar desde as áreas mais altas ou mesmo desde o vale, permitindo que seja utilizado em duas estações diferentes, conforme a água se torna mais escassa. 
Os caminhos estão conectando diferentes áreas para a exploração dos recursos necessários para a sobrevivência, principalmente no que concerne aos locais de água e pastagens. Desta forma, nos trajetos que unem as áreas de recursos, estão os possíveis locais onde há maior possibilidade de identificação de registros arqueológicos.

A formação do registro arqueológico, nas áreas mais altas do interior das serras, está diretamente relacionada à mobilidade de inverno e aos períodos curtos de permanência e, além disso, a permanência do pastor é restrita (pois os animais são deixados pastando e o pastor sai e volta ao local, não permanecendo), indicando a possibilidade de um registro escasso e muito sutil. Contudo, há uma reutilização constante dos caminhos e das áreas que oferecem recursos (pastagem, água e/ou proteção). Este comportamento de reutilização dos caminhos e lugares pode ser utilizado como um indicativo para definir áreas de maior potencial arqueológico. Isto porque, provavelmente, os registros estarão dispostos ao longo dos caminhos, sendo estas as áreas selecionáveis para identificar esses comportamentos pastoris do passado.

É provável que locais com maior concentração de restos sejam aqueles relacionados a áreas de cultivos e locais de assentamentos residenciais. Estes locais distinguem-se em duas áreas potenciais. Primeiro, as áreas dos vales sobre as planícies aluviais. Estas áreas continuaram sendo ocupadas até os dias atuais, portanto é possível que o palimpsesto de ocupações dificulte a identificação de registros mais antigos, porém, ao mesmo tempo, ateste sobre a persistência das populações nestas áreas (como já foi indicado por Tarragó e González (2005)). Segundo, nos vales das regiões mais elevadas, sobre os caminhos é possível que existam registros de assentamentos residenciais ao estilo da casa na qual habita Dom Yucra ou Dom Lorenzo, que chamamos de "casa de campo" no capítulo 3.

A identificação dos registros da presença pastoril nessas serras também pode ser indicada pelo manejo exercido por essas populações sobre as outras espécies que não aquelas comestíveis pelo rebanho. É provável que este seja um processo de manejo contínuo que se perpetua por muitos anos no ato de percorrer os caminhos de pastoreio e no depósito de estrume dos animais como disseminador de sementes e adubo. No alto das serras, ao identificar as áreas com vegetação diferenciada, são áreas de uso pastoril, permitindo atestar a presença de grupos humanos acompanhados dos rebanhos. Porém, o resultado do manejo é extremamente sutil, portanto difícil explanar sobre ocupações no 
passado a partir deste processo, mas é possível distinguir áreas que estão sendo ocupadas na atualidade e tentar estabelecer paralelos com o passado.

\section{2 - Sobre a complexidade da dinâmica do pastoreio}

O pastoreio e, principalmente, os caminhos pastoris são e foram essenciais para a existência e desenvolvimento das sociedades andinas. Levantar esses dados talvez permita avanços na compreensão do desenvolvimento dos grupos do passado do vale de Santa María como um ambiente integrado.

Os registros arqueológicos deste local indicam a presença de diversos currais, todos com características muito parecidas. Atualmente, os pastores não deixam os seus rebanhos confinados em currais nas redondezas da Virgem Perdida. Os animais ficam soltos para pastarem como acontece em diversas áreas. Os dados coletados etnograficamente indicam que os currais têm a função de conter os animais para alguma finalidade específica: para a separação das fêmeas prenhas dos machos, dos filhotes dos adultos, para ordenar e selecionar a reprodução, para esquilar os animais e protege-los. No geral, os currais para os animais dormirem apresentam paredes baixas apenas como demarcadoras do local, há pouca preocupação com a contenção do rebanho.

Apartir de outras perspectivas, é possível levantar algumas questões que talvez sejam interessantes para representar esses registros indicados por diversos currais, todos juntos em áreas com acesso a água. Os rebanhos móveis permitiram a prosperidade de diversos grupos nas serras andinas. Os rebanhos abasteceram essas comunidades com produtos primários e secundários e as caravanas permitiram trocas de mercadorias e informações em escala regional (Tripcevich e Capriles 2016; Kuznar 2001b; Nielsen 2001). Porém, uma das questões que se tentou demonstrar neste trabalho é que o pastoreio é mais que uma resposta puramente econômica, é uma escolha que envolve questões ambientais, sociais e ideológicas, além de diversas instituições internas que ordenam o uso das terras, pastagens, fontes de água e tamanho do rebanho.

Por sua vez, as dinâmicas entre populações pastoris e agricultores são destacadas no mundo todo como fruto de desenvolvimento e complexidade para ambos os grupos (Smith 2008; Browman 2008; Alezadeh 2008). Nos Andes, a dicotomia entre a forma de vida pastoril e a de agricultores é marcada por diversas combinações entre pastoreio e 
cultivos que caracterizam as inovações e particularidades regionais que as pessoas adotaram nos contextos específicos (ver Capriles e Tripcevich 2016; Kuznar 2001). O pastoreio apresenta diversas vantagens, principalmente em áreas marginais, como é o caso do vale de Santa María, permitindo uma economia mista que integra as vantagens do pastoreio e seus produtos às da agricultura e vice-versa.

A arqueologia tem dado maior atenção ao contexto social dos grupos agrícolas, principalmente quando o tema é a complexidade. Porém, é importante levantar algumas hipóteses sobre as populações pastoris e sobre a possibilidade destes grupos contribuírem com o incremento e as transformações. Primeiramente, há de se levar em consideração a importância do rebanho dentro dos símbolos de prestígio e, por conseguinte, a importância do acesso aos locais com água e pastagens (Aldenderfer 2016).

Talvez esta relação entre prestígio e controle da água e pastagens esteja jogando um papel fundamental na complexificação social dessas populações. Se as estratégias de gerenciamento de rebanhos deixam bem clara a falta de uso de currais para a contenção do rebanho, é possível que a presença de diversos currais próximos a locais de água, como a Virgem Perdida, estejam atestando o controle das fontes de sobrevivência dos rebanhos. Desta forma, o controle de um determinado grupo sobre o acesso aos locais de água e pastagens, provavelmente implicaria uma distinção entre os grupos: aqueles que acessam as áreas e aqueles que controlam o acesso. Isto porque, para a sobrevivência do rebanho, o acesso aos recursos é fundamental, sem este acesso o rebanho perece.

Este é um tema que pode ter-se apresentado como hipótese para se pensar algumas condições do passado, talvez em momentos onde o controle de áreas e recursos fosse importante para o incremento de determinados grupos em uma população em crescimento e desenvolvimento. Porém, para atestar estas informações, ainda há muitos dados a serem levantados e testados, e o objetivo desta tese é o de levantar dados que possam contribuir para a formulação de hipóteses a serem testadas e reformuladas por arqueólogos. No caso, para se afirmar o incremento da complexidade através do controle de áreas e tamanho dos rebanhos, é necessário um estudo minucioso sobre os tamanhos dos currais, o incremento de currais em determinados períodos e o tipo de animal que continham (fêmeas, machos, filhotes ou misturados). 
Ainda assim, pensar sobre o controle dos recursos também levanta outras questões, como a função e o alcance das instituições internas do pastoreio que regulam esse tipo de comportamento.

\section{3 - Questões da vida moderna que afetam os pastores}

\section{1 - Influências das mudanças}

Ainda falando sobre os caminhos, um dos pontos que ficou claro é que as pessoas identificam os caminhos por onde se transita, utilizando aquelas indicações exploradas no capítulo 4. Ao mesmo tempo, também utilizaram elementos externos de indicação como: o tipo de ruína que deve se encontrar ao transitar por tal caminho, ou ainda informações sobre o aspecto de formações rochosas, tipos de solo, presença ou ausência de vegetação. Isso permite assumir que os aspectos da paisagem têm um papel fundamental na localização e nos trajetos que as pessoas fazem. As mudanças na paisagem afetam diretamente estas pessoas, pois modificam as informações às quais se ordena o próprio conhecimento. Porém, ainda com mudanças tão rápidas como as que estão acontecendo em Santa María, como a presença recente de grandes vinhedos e o crescimento demográfico, as pessoas atualizam constantemente as informações do meio a sua volta e são capazes de reorganizar essas informações e manter os caminhos. O grande problema é quando os caminhos são interrompidos.

A perda de terras de pastoreio é um problema que afeta os grupos pastores no mundo todo. As terras indígenas não estão sendo respeitadas por outros grupos, isto tem criado uma série de dificuldades para os grupos tradicionais em relação aos seus direitos e respeito à terra.

Desde as savanas africanas até a Mongólia e os Andes, o grande problema que está sendo exposto é a falta de opção dos grupos no acesso e uso da terra. Este problema acirra a diferença na forma como os grupos veem e compreendem a terra, enquanto para o pastoreio tradicional a noção de terra é aberta e foca-se no grupo ou na comunidade, diferente das sociedades ocidentais onde a terra é individual e divisível. Por sua vez, em um panorama de mudanças ambientais, os grupos pastoris móveis representam dinâmicas de padrões de subsistência flexíveis e facilmente adaptáveis, onde as mudanças do ambiente podem ser facilmente incorporadas ao padrão já existente. 
Cada um dos tipos de assentamento na serra do Cajón pode ser visto como indicativos materiais das mudanças através do tempo. As casas na cidade são um fenômeno relativamente moderno, impulsionado pelas necessidades do mundo atual. Ao mesmo tempo, o abandono ou mudança no uso dos postos temporários também denota as mudanças que vêm ocorrendo em relação ao uso e ocupação do espaço.

No que se refere ao comportamento, parece que a atividade pastoril é compatível com outras atividades do mundo moderno. Os pastores apresentam um comportamento flexível, os movimentos sazonais obrigam os pastores: a) prever uma série de variáveis climáticas e fisiográficas para a sobrevivência dos humanos e do rebanho, transitando por diversos nichos ecológicos, dos quais podem tirar vantagens; b) transitar por diversos territórios, entrando em contato com grupos diferentes e facilitando as trocas. Esta condição de mobilidade sazonal dos grupos pastoris tem contribuído para a flexibilização de atividades econômicas (como a presença de agricultura) e para as relações de trocas com outros grupos e mercados.

Existem casos, como o de Dom Vicêncio, que logrou integrar, de forma satisfatória, as exigências do mundo moderno à sua tradição pastoril. Dom Vicêncio mudou-se com a família para Las Mojarras, ao pé da serra, de onde consegue ir e voltar da serra para continuar cuidando dos animais. Quando Dom Vicêncio foi trabalhar na cidade, a vários quilómetros de Santa María, seus filhos seguiram mantendo o rebanho, e, quando já não era possível para eles cuidarem dos animais, foi contratado um terceiro para fazê-lo.

Apesar das mudanças, Dom Vicêncio conseguiu integrar as duas formas de vida. Por um lado, nunca perdeu o seu gado, nem a sua forma de vida. A casa de Las Mojarras estrutura-se como uma casa de campo, eles têm um terreno suficientemente grande para ter animais, também é possível acessar os pastos de inverno e locais de água não perenes nas serras sem muita dificuldade e manter os animais por perto se necessário. Por sua vez, a proximidade da cidade, permite que ele e sua família acessem as facilidades que o centro urbano oferece. Desta forma, acessar as facilidades modernas não afetaria diretamente a forma de vida pastoril, a grande mudança refere-se à apropriação e uso das terras.

A literatura recente sobre pastoreio tem indicado várias mudanças nas estratégias tradicionais de subsistência, em relação à sedentarização e aos mercados (Leslie e McCabe 2013; McCabe 1994). Estes estudos mostram uma mudança de perspectiva (ver 
McCabe 2005), entre os grupos Turkana, é possível observar uma imposição de sistemas externos, os quais têm criado alterações nas estratégias mercadológicas, na mobilidade e na dieta destes grupos. Ainda quando, os Turkana resistem quanto à prática de troca de gado, o que somente fazem por tabaco e armas (existe uma relação estabelecida por estas pessoas entre a obtenção de armas e o aumento do rebanho), intensas mudanças são evidentes.

\begin{tabular}{|c|c|c|c|c|}
\hline & $\begin{array}{l}\text { Tipo de } \\
\text { pastoreio }\end{array}$ & $\begin{array}{l}\text { Distinção } \\
\text { entre } \\
\text { inverno e } \\
\text { verão }\end{array}$ & $\begin{array}{l}\text { Grau de } \\
\text { mobilidade }\end{array}$ & Tipos de mudança \\
\hline $\begin{array}{l}\text { Pastoreio } \\
\text { no Vale } \\
\text { de Santa } \\
\text { Maria }\end{array}$ & $\begin{array}{l}\text { Agro-pastoril } \\
\text { com } \\
\text { movimentos } \\
\text { sazonais } \\
\text { (casa } \\
\text { residencial } \\
\text { fixa) }\end{array}$ & Sim & Baixo & $\begin{array}{l}\text {-Mudança na localização das casas } \\
\text { residenciais para próximo das } \\
\text { cidades; } \\
\text {-Mudança no consumo de produtos } \\
\text { (abandono e incremento); } \\
\text {-Venda de animais nos mercados } \\
\text { regionais e locais; } \\
\text {-Incremento dos rebanhos por } \\
\text { facilidade da cidade. }\end{array}$ \\
\hline $\begin{array}{l}\text { Pastoreio } \\
\text { entre os } \\
\text { Turkana }\end{array}$ & $\begin{array}{l}\text { Pastoreio } \\
\text { nômades } \\
\text { (casa } \\
\text { residencial } \\
\text { móvel) }\end{array}$ & Sim & Alto & $\begin{array}{l}\text {-Mudança nas rotas de mobilidade } \\
\text { para próximo das cidades; } \\
\text {-Mudança no consumo de produtos } \\
\text { (abandono e incremento); } \\
\text {-A venda de animais somente por } \\
\text { tabaco e armas; } \\
\text {-Incremento de rebanho por defesa } \\
\text { (não perdem tanto gado). }\end{array}$ \\
\hline
\end{tabular}

Tabela 13 - Quadro comparativo de modos pastoris atuais. 
O pastoreio tradicional, na sua grande variabilidade de formas e adaptações, indica que existem grupos com um nomadismo intenso e outros com um grau de mobilidade menor. O sistema pastoril em Santa María apresenta um grau de mobilidade em menor intensidade, quando comparado a grupos como os Turkana do Quênia, porém isto não indica que estejam num processo de sedentarização.

\section{2 - As mudança e adaptabilidade quanto ao assentamento}

Sem entrar em questões de cunho puramente arqueológico, é possível perceber uma mudança estrutural no sistema pastoril em Santa María. Primeiramente, existem dois momentos diferentes nos quais as mudanças ocorreram, que indicam claramente as diferenças quanto a uma melhor adaptação às condições atuais sem perder a forma de vida tradicional.

O primeiro momento pode ser ilustrado pela história de Dom Vicêncio, com mudança para as proximidades do centro urbano. Por sua vez, estas adaptações não implicam mudanças estruturais profundas, a família continua dedicando-se ao pastoreio em tempo parcial $^{29}$, a estrutura da casa (apesar de próxima ao centro urbano) apresentase como uma repetição da casa de campo que antes habitavam, tanto no que se refere à estrutura arquitetônica, quanto no entorno, uma vez que a casa continua contando com currais, galinheiros suspensos, horta, pomar e áreas de pastagens.

Quanto ao pastoreio, manteve-se a mesma estrutura: os animais eram levados para pastar, o pastor ausentava-se o tempo possível e necessário para realizar outras atividades (neste caso trabalhar em outra cidade). Portanto, o uso da paisagem permaneceu, assim como as relações de gênero e geracionais, já que as mulheres continuaram dedicando-se a atividades dentro do circuito da casa residencial e as crianças continuaram ajudando na atividade do pastoreio. Os filhos de Dom Vicêncio também seguiram esta mesma estrutura, morando muito próximos à casa do pai, também intercalam atividades assalariadas com o pastoreio nas serras.

\footnotetext{
${ }^{29}$ Como foi colocado anteriormente, umas das características centrais do pastoreio é a compatibilidade com outras atividades econômicas de forma complementária.
} 
O outro momento de mudança corresponde ao que viveu Guadalupe e Dom Lorenzo. Guadalupe foi morar próximo ao centro urbano, mas não conseguiu manter a atividade pastoril. Ela faz uso das serras para a coleta de alguns produtos, porém não possui um rebanho. O principal problema de Guadalupe é o fechamento das propriedades em volta da sua casa, o que a impede de ter animais e leva-los até a serra para pastar. Já Dom Lorenzo permaneceu morando nas serras, porém o seu modo de vida também está sendo afetado pela propriedade privada que o obriga a estar presente com os seus animais em tempo integral (por causa dos problemas com as propriedades cercadas que as cabras não respeitam), permanecer na serra parece ser impraticável para Dom Lorenzo, pois ele precisa acessar a cidade principalmente para comprar certos produtos de que necessita.

No que se refere à localização dos assentamentos, as pessoas tendem a morar mais próximo às cidades. Porém, isto não marcou uma mudança importante quando o acesso às serras ainda era o mesmo ao qual estavam acostumados, pois apesar de propriedades com donos particulares, as terras tinham um funcionamento comunal e os pastores eram livres para cruzar as terras dos seus vizinhos e acessar as pastagens de inverno e os acessos à água. O grande problema surge no processo de venda e privatização definitiva das propriedades. A impossibilidade de cruzar e acessar terras tem provocado uma diminuição alarmante nas condições para o pastoreio, o que leva a crer que haverá uma consequente diminuição de pastores e rebanhos nas serras, nos próximos anos.

No que se refere à estrutura dos assentamentos das serras, as mudanças foram mais visíveis. As casas no alto das serras, ao que parece, estão diminuindo em número nos últimos anos. Percebe-se que o povoamento da região serrana era intenso, as gerações começaram a se dividir entre a vida nas serras e na cidade, gradualmente. Desta forma, as casas nas serras têm diminuído e mudado de função. Na porção que corresponde ao lado da serra do Cajón mais próximo a Santa María, a maioria das pessoas com quem conversei vive em uma zona mais próxima ao centro urbano. Entre aqueles que ainda vivem nas serras, a conexão com o centro urbano é muito intensa. Já, no vale de El Carmen, ainda existem muitas famílias que vivem de maneira tradicional no interior das serras. Talvez umas das questões que tenha contribuído para esta permanência é a existência de uma escola na zona serrana e a persistência de algumas caravanas.

A mudança na permanência nas casas de campo também aparece com relação aos currais no alto das serras e aos postos temporários. A presença de currais abandonados 
pode indicar várias coisas, as quais não tive o tempo suficiente ainda para analisar e poder expor essas causas de forma sistemática. Ainda assim, os postos temporários em utilização, que pude identificar, estavam mais em baixo das serras, próximos a casas e porteiras e eram utilizados para se guardar material. O posto temporário identificado no alto da serra estava abandonado, sendo apenas o curral utilizado.

Ainda quando há uma transferência da casa residencial, a estrutura desta detém os traços daquelas casas residenciais serranas, e, mesmo quando há um abandono de algumas estruturas no alto das serras, os currais e as zonas de pastoreio continuam em uso. Isto permite pensar que a capacidade plástica deste sistema pastoril admite um leque muito maior de opções adaptativas que, por sua vez, permitem a perpetuidade do pastoreio e não o seu fim.

\section{Últimas palavras}

Concluindo, a fim de melhor entender o contexto pastoril de uso da terra e seus recursos e a relação com a paisagem entre estes pastores do vale de Santa María, foi importante estabelecer as diretrizes que regiam esse sistema, que, por sua vez, influenciam diretamente o comportamento material e a relação com os registros arqueológicos da região. Desta forma, a relação entre ambiente, animais e humanos é mais estreita do que parecia em um primeiro momento, permitindo estabelecer parâmetros comparativos inclusive com os outros momentos de pastoreio destes vales.

Assim, nos capítulos 2 e 3, definiu-se o modelo pastoril que é a base para a compreensão da paisagem dos capítulos 4 e 5 . Estes dados permitem explanar sobre a presença humana nestas serras, a relação com a verticalidade andina e o contexto do pastoreio em ambientes áridos, os quais permitirão aos arqueólogos e antropólogos lidar com os dados e formular hipóteses a fim de uma compreensão mais completa do lugar do pastoreio no vale de Santa María, na arqueologia andina e na teoria mundial sobre pastores.

Desta forma, as populações atuais dão uma mostra das possibilidades de modos de vida e apreensão do passado, ao mesmo tempo em que mostram quão difícil pode ser essa interpretação. O uso das mesmas áreas pode ser colocado como um ponto central para estabelecer hipóteses e discussões, visando a uma relação estreita entre: a 
sazonalidade de fauna e flora, o padrão dos movimentos e assentamento e a utilização da terra e seus recursos. Ainda quando os significados específicos dados aos lugares e características da paisagem podem mudar ao longo do tempo, a necessidade de água e pastagens para os rebanhos traça um marco decisório na forma como estes pastores relacionam-se com o meio à sua volta.

Estas discussões permitem romper com a imagem do "puro nômade", mostrando como as populações pastoris são fluidas e oportunistas, em constante contato com outros grupos, centros e mercados. O pastoreio, portanto, é parte de um importante sistema adaptativo de uso da terra e seus recursos, indicando que talvez o ponto chave da persistência destes grupos seja justamente a capacidade de aceitação e incorporação das mudanças a seu modo de vida. Nos anos 1960, acreditou-se que o pastoreio tradicional começaria a ser abandonado pelos grupos que o praticavam, considerando-se que os grupos pastores estariam resistindo à modernização. É importante destacar a natureza adaptativa deste sistema, tanto no que se refere ao passado como no presente.

A capacidade plástica destes grupos pastores tem contribuído em muito para a persistência deste modo de vida tradicional no vale de Santa María, porém, ao mesmo tempo, os avanços da vida moderna (como a extensão de monoculturas, crescimento demográfico em direção às serras e abandono das mesmas, uso desenfreado das fontes de água e o estabelecimento de cercados) estão levando a mudanças no ambiente que talvez representem o fim desses nichos ecológicos andinos.

Se, por um lado, o pastoreio faz uso - e necessita - das fontes de água e locais de pastagens naturais, também existe um cuidado sobre essas áreas. Os pastores fazem uso das pastagens de forma cíclica. Se existe uma degradação, o próprio processo sazonal de mobilidade permite que as pastagens "descansem" e cresçam novamente. Ao fecharem as áreas, os pastores são impossibilitados de acessar esses locais, com isso haverá uma perda significativa de rebanhos e um maior confinamento de animais, pois com as cercas, a sazonalidade diminui.

Por sua vez, os padrões alimentares das populações tradicionais estão mudando ao longo de todo o globo, há uma substituição gradual de produtos tradicionais e locais por industrializados (Murrieta et al 2008). Porém, estes universos de produção - como é o caso dos pastores do vale de Santa Matía - demonstram que os produtos tradicionais ainda são fundamentais para a subsistência de um largo grupo de pessoas. 
A etnoarqueologia nos últimos anos tem- se comprometido cada vez mais com a produção de uma ciência mais crítica e com maior responsabilidade social, gerando ideias que contribuam com o debate arqueológico, mas que também sejam uma ferramenta útil para as populações com quem se trabalha. Portanto, espero que, ao levantar estes dados sobre a existência e persistência destes pastores em Santa María, também provoque uma sensibilização à verdadeira realidade que estas pessoas estão enfrentando sobre a perda gradual de ecossistemas e do meio de vida. 


\section{Bibliografia}

Abusuwar, A.O. e Yahia El Hadi O. 2010. Pastoralist and seasonality: their effects on range productivity and carrying capacity in a semi-arid rangeland of Sudan (Southeast Darfur State). Agric. Biol. J. N. Am., Vol. 1, №2.

Acha, M. 2008. Diferentes formas de definir los territorios, diversidad y la identidad en los valles de Tafí. Actas del IX Congreso Argentina de Antropología Social.

2009. Formas de resistencia frente al proceso de incorporación del indígena al Estado Nacional. Diferentes prácticas cotidianas en Tafí del Valle. Anales RAM.

Acuto, F.A. 2007. Fragmentación vs Integración Comunal: Representando el Período Tardío del Noroeste Argentino. Estudios Atacameños. Arqueología y Antropología Surandinos, 34.

Albeck, M.E. 2000. La vida agraria de los Andes Sur. In: M. Tarragó e J. E. Burucúa (eds), Nueva Historia Argentina, Tomo 1. Editorial Sudamericana.

Aldenderfer, M. 2001. Andean Pastoral Origins and Evolution: The Role of Ethnoarchaeology. In: L. Kuznar (ed), Ethnoarchaeology of Andean South America: contributions to archaeological method and theory. International Monographs in Prehistory, Michigan.

2016. Forwards. In: J.M. Capriles e N. Tripcevich (eds), The Archaeology of Andean Pastoralism. University of New Mexico Press.

Alizadeh, A. 2008. Archaeology and the Question of Mobile Pastoralism in the Late Prehistory. In H. Barnard and W.Z. Wendrich (eds.), Archaeology of Mobility: Old World and New World Nomadism. Cotsen Institute of Archaeology, Los Angeles.

Arango, M.E. and Andoque, F. 1999. Managing the world: territorial negotiations among the Andoque people of the Colombian Amazon. In: P.J. Ucko e R. Layton (editors), The Archaeology and Anthropology of Landscape. Routledge, Londres e Nova York. 
Arruti, J. M. A. 1997. A emergência dos "remanescentes": notas para o diálogo entre indígenas e quilombolas. Revista Mana, Rio de Janeiro, V. 3, $\mathrm{N}^{\circ}$ 2, Oct. Available from: http://www.scielo.br/.

Aschero, C. 2000. El poblamiento del territorio. In: M. Tarragó e J. E. Burucúa (eds), Nueva Historia Argentina, Tomo 1. Editorial Sudamericana.

Baner, S., B.A. Nolet, J. Giske, J. Chapman, S. Akesson, A. Hedenstrom, J.M. Frywell. 2011. Cues and decision rules in animal migration. In: J.M. Fryxell e A.R.E. Sinclair (eds), Animal migration: A synthesis. Oxford University Press.

Barret, J.C. 1999. Chronologies of landscape. In: P.J. Ucko e R. Layton (eds), The Archaeology and Anthropology of Landscape. Routledge, Londres e Nova York.

Bartolomé, M. 2008. La diversidad de las diversidades: Reflexiones sobre el pluralismo cultural en América Latina. Cuad. antropol. soc. $\mathrm{N}^{\circ} 28,33-49$.

Basso, K.H. 1996. Wisdom sites in places: Notes of a Western Apache Landscape. In: S. Feld e K.H. Basso (eds), Sense of place. School of American Research Press, New Mexico.

Behnke et al. 2011. Pastoral migration: mobile systems of livestock husbandry. In: J.M. Fryxell e A.R.E. Sinclair (eds), Animal migration: A synthesis. Oxford University Press.

Binford, L. 1978. Dimensional Analysis of Behavior and Site Structure: Learning from an Eskimo Hunting Stand. American Antiquity, Vol. 43, N³, 330-361.

1980. Willow Smoke and Dogs' Tails: Hunter-Gatherer settlement systems and archaeological site formation. American Antiquity. Vol. 45. $\mathrm{N}^{\circ} 1$.

1991. En busca del pasado. Crítica, Barcelona.

Blench, R. 2001. 'You can't go home again'. Pastoralism in the new millennium. FAO, [online] http://www.eldis.org/vfile/upload/1/document/0708/DOC9709.pdf.

Boccara, G. 2007. Poder colonial e etnicidade no Chile: territorialização e reestruturação entre os Mapuche da época colonial. Revista Tempo, Niterói, V. 12, N ${ }^{\circ} 23$. Available from: http://www.scielo.br/. 
Boixadós, R. 2011. El fin de las guerras calchaquíes. La desnaturalización de la nación Yocavil a La Rioja. Corpus. Archivos virtuales de la alteridad americana, Vol. 1, $\mathrm{N}^{\mathrm{o}} 1$.

Bokonyi, S. 2015. Definitions of animal domestication. In: J. Clutton-Brock, The Walking Larder: patterns of domestication, pastoralism and predation. Unwin Hyman Ltd, Londres.

Botin, L. 2013. Landscape and Dwelling. In: L. Botin, A. Carter e R. Tyrrell (eds), Dwelling, Landscape, Place and Making. Aalborg Universitetsforlag.

Bottema, S. 2015. Some observations on modern domestication processes. In: J. CluttonBrock, The Walking Larder: patterns of domestication, pastoralism and predation. Unwin Hyman Ltd, Londres.

Bourdieu, P. 1989. O Poder Simbólico. Difusão Editorial, Lisboa.

Briones, C. 2002. Mestizaje y Blanqueamiento como Coordenadas de Aboriginalidad y Nación en Argentina. RUNA, Universidad de Buenos Aires, Vol. XXIII: 61-88.

2007. Teorías performativas de la identidad y performatividad de las teorías. Tabula Rasa, $\mathrm{N}^{\circ} 6,55-83$.

Browman, D. L. 1983. Andean arid land pastoralism and development. Mountain research and development, Vol3, N³.

2008. Pastoralism Nomadism in the Central Andes. A historic retrospective example. In H. Barnard and W.Z. Wendrich (eds.), Archaeology of Mobility: Old World and New World Nomadism. Cotsen Institute of Archaeology, Los Angeles.

Cabrera, F. 2015. Análisis funcional del conjunto arquitectónico RCh 8, localidad arqueológica de Rincón Chico, valle de Yocavil, Catamarca. Revista del Museo de Antropología, Vol. 8, Nº 1 .

Cantarelli, V. e Torcoleti, A. 2009. Ocupaciones serranas del Noroeste Argentino. Arquitectura comparada de la Sierra del Cajón, Provincia de Catamarca. VIII Jornadas de Jóvenes Investigadores en Ciencias Antropológicas, Buenos Aires. 
Cantarelli, V., D. Rampa, M. Grattone. 2014. Dos sitios de altura en la Sierra del Cajón: El estado actual de las investigaciones en la localidad arqueológica de Pichanal, provincia de Catamarca. Zaranda ideas [online], Vol. 11.

Carrasco, M. 2000. Los derechos de los pueblos indígenas en Argentina. IWGIA, Buenos Aires.

Chang, C. 2006. The Grass is greener on the other side. A study of pastoral mobility on the Eurasian steppe of Southeastern Kazakhstan. F. Sellet, R. Graves e Pei-Lin Yu (eds). Archaeology and Ethnoarchaeology of Mobility. University Press of Florida, Gransville.

Casey, E.S. 1996. How to get from space to place in a fairly short stretch of time: phenomenological prolegomena. In: S. Feld e K.H. Basso (eds), Sense of place. School of American Research Press, New Mexico.

Cassidy, R. 2007. Introduction: Domestication Reconsidered. In: R. Cassidy e M. Mullin (eds), Where the Wild Things are Now: Domestication Reconsidered. Oxford.

Certeau, M. De 2000. La invención del cotidiano. 1 Artes de Hacer. Universidad Iberoamericana, Mexico.

Chang, C. e Tourtellotte, P.A 1993. Ethnoarchaeological survey of pastoral transhumance sites in Grevena region, Greece. Journal of Field Archaeology. Vol. $20, \mathrm{~N}^{\circ} 3$.

Clutton-Brock, J. 2015. Introduction. In: J. Clutton-Brock, The Walking Larder: patterns of domestication, pastoralism and predation. Unwin Hyman Ltd, Londres.

Clutton-Brock, J. 2015b. Introduction to pastoralism. In: J. Clutton-Brock, The Walking Larder: patterns of domestication, pastoralism and predation. Unwin Hyman Ltd, Londres.

Cobo, C. e Romero, M. 2012. Importancia de la interacción hombre-animal durante el presacrificio bovino: Revisión. Biosalud, Vol. 11, №2.

Correa, R. e Rosendahl, Z. 2008. A geografia cultural no Brasil. Revista da ANPEGE, Vol. 8. 
Cresswell, W. e Quinn, J.L. 2011. Predicting the optimal prey group size from predator hunting behavior. Human Ecology, Vol. 80, Nº 2.

Cresswell, K.A., W.H. Satterthwaitte e G.A. Sword. 2011. Understanding the evolution of migration through empirical examples. In: E.J. Milner-Gullands, J.M. Fryxell, A.R.E. Sinclair (eds), Animal Migration: A Synthesis, Oxford University Press.

David, N. e Kramer, C. 2001. Ethnoarchaeology in action. Cambridge University Press.

David, N. e Kramer, C. 2002. Teorizando a etnoarqueologia e a analogia. Horiz. antropol. [online], vol.8, n.18.

David, B. e Thomas, J. 2008. Handbook of Landscape Archaeology, Left Coast Press, Walnut Creek.

Darvill, T. 1999. The historic environment, historic landscapes, and space-time-action models in landscape archaeology. In: P.J. Ucko e R. Layton (eds), The Archaeology and Anthropology of Landscape. Routledge, Londres e Nova York.

Escola, P., S. Hocsman e M. del Pilar Babot. 2013. Entre las residencias y los campos de cultivo. Aportes de los cuchillos/raederas de módulo grandísimo a la cuestión del laboreo agrícola en Antofagasta de la Sierra (Puna de Catamarca) durante el primer milenio d. C. Relaciones de la Sociedad Argentina de Antropología, Vol. $38, \mathrm{~N}^{\circ} 1$.

Erickson, C.L. e Walker, J.H. 2009. Precolumbian causeways and canals as Landesque capital. In: J.E. Snead, C.L. Erickson, J.A. Darling (eds), Landscapes of movement: Trails, paths and roads in anthropological perspective. University of Pennsylvania Museum of Archaeology and Anthropology, Philadelphia.

Evas-Pritchard. E.E. 2011. Os Nuer. Perspectiva, São Paulo.

Faberman, J. e Boixadós, R. 2006. Sociedades indígenas y encomienda en el Tucumán colonial. Un análisis comparado de la visita de Luján de Vargas. Revista de Indias, Vol. LXVI, $\mathrm{N}^{\circ} 238$.

Feld, S. 1996. Waterfalls of Songs. An acoustemology of place resounding in Bosavi, Papa New Guinea. In: S. Feld e K.H. Basso (eds), Sense of place. School of American Research Press, New Mexico. 
Feld, S. e Basso, K.H. 1996. Introduction. In: S. Feld e K.H. Basso (eds), Sense of place. School of American Research Press, New Mexico.

Ferguson, T.J. e Colwell-Chanthaphonh, C. 2006. History is in the land. Multivocal tradition in Arizona's San Pedro Valley. University of Arizona Press, Tucson.

Figueroa, G.G. 2013. Estrategias productivas en Aguada de Ambato (Catamarca, Argentina). Relaciones de la Sociedad Argentina de Antropología, XXXVIII.

Féblot-Augustins, J. 1993. Mobility Strategies in the Middle Paleolithic of Central Europe and Western Europe: Elements of Stability and Variability. Journal of Anthropological Archaeology. Vol. 12. №3.

Flores, U.A. e Romero, M.F. 2013. Las características más importantes del clima local y la influencia del factor topográfico para el desarrollo de las actividades turísticas en el distrito de La Puerta, Departamento de Ambato. XXII Encuentro Nacional de Profesores de Geografía, [online], http://www.isnsc.com.ar/assets/eje_08_03_flores_romero.pdf.

Frachetti, M. 2008. Variability and dynamic landscape of mobile pastoralism in ethnography and prehistory. In: H. Barnard and W.Z. Wendrich (eds), Archaeology of Mobility: Old World and New World Nomadism. Cotsen Institute of Archaeology, Los Angeles.

Gaulejac, V. de y Ochoa, H. S. 2002. Memoria e historicidad. Revista Mexicana de Sociología, Vol. 64, $\mathrm{N}^{\circ}$ 2, 31-46.

Garrow, D. e Yarrow, T. 2012. Introduction: Archaeological Anthropology. D. Garrow e T. Yarrow (eds), Archaeology and Anthropology. Understanding Similarities, Exploring Differences. Oxbow Books, Oxford.

Göbel, B. 2002. La arquitectura del pastoreo: Uso del espacio y sistema de asentamientos en la Puna de Atacama (Susques). Estudios Atacameños, N²3, p.53-76.

González, L. 2000. La dominación inca. Tambos, caminos y santuarios. In: M. Tarragó e J. E. Burucúa (eds), Nueva Historia Argentina, Tomo 1. Editorial Sudamericana.

González, L. e Tarragó, M. 2004. Dominación, resistencia y tecnología: La ocupación incaica en el Noroeste Argentino. Chungará (Arica), Vol. 36, №2. 
2004b. Arquitectura social y ceremonial en Yocavil

(Catamarca). Relaciones de la Sociedad Argentina de Antropología XXIX.

2005. Vientos del Sur. El Valle de Yocavil (Noroeste Argentino) bajo la dominación incaica. Estudios Atacameños, №29.

González Rex, A. 2004. La arqueología del Noroeste Argentino y las culturas formativas de la Cuenca del Titicaca. Relaciones de la Sociedad Argentina de Antropología XXIX.

González Ruibal, A. 2003. La experiencia del otro. Una introducción a la etnoarqueologia. Akal. Madrid.

2012. Hacia otra arqueología. Diez propuestas. Complutum. Vol. $23, \mathrm{~N}^{\mathrm{o}} 2,103-116$.

Gordillo, I. 2010. Los pueblos del jaguar. Manual de Arqueología de Catamarca. Dirección Provincial de Antropología, Secretaria de Cultura, Catamarca (em edição).

Gow, P. 1995. Land, people and paper in Western Amazonia. In: E. Hirsch e M. O’Hanlon (eds), The Anthropology of Landscape: perspectives on place and space. Oxford University Press.

Guber, R. 2001. La etnografía. Método, campo y reflexibilidad. Norma, Bogotá.

Gnecco, C. e Ayala, P. 2011. Introduction. What is to be done? Elements for a discussion. In: C. Gnecco e P. Ayala (eds), Indigenous People and Archaeology in Latin America. Left Coast Press.

Grecco, C. 2014. La cronología del valle de Yocavil. Escalas, datos y resultados. Arqueología 20, Dossie.

Grecco, C. e Cabrera, F. 2009. Notas sobre um conjunto constructivo del Bajo de Rincón Chico de Yocavil. Comechingonia Virtual, Vol. 3, №1.

Haber, A.F. 2001. Observations, Definitions and Pre-understandings in the Ethnoarchaeology of Pastoralism. In: L. Kuznar (ed), Ethnoarchaeology of 
Andean South America: contributions to archaeological method and theory. International Monographs in Prehistory, Michigan.

Haesbaert, R. 2002. Territórios Alternativos. Ed. Universidade Federal Fluminense, Niteroi.

Harmansah, O. 2014. Event, Place, Performance: Rock Reliefs and Spring Monuments in Anatolia. In. O. Harmansah (ed), Of rocks and water. Towards an archaeology of place. Owbon Books.

Haviland, W.A., H.E.L Prins, D. Walrath e B. McBride. 2011. Introdução à Antropologia. In: W.A. Haviland, H.E.L. Prins, D. Walrath e B. McBride (eds) Princípios da Antropologia. CENGACE Learning. São Paulo.

Heidegger, M. 1971. Building Dwelling Thinking. In: Poetry, Language, Thought. Harper Colophon Books, Nova York.

Hirsch, E. 1995. Landscape: between place and space. In: E. Hirsch e M. O’Hanlon (eds), The Anthropology of Landscape: perspectives on place and space. Oxford University Press.

Hodder, I. 1986. The present past: an introduction to anthropology for archaeologists. B.T. Batsford, Londres.

2012. Archaeology and Anthropology: The State of the Relationship. D. Shankland (ed), Archaeology and Anthropology. Past, Present and Future. ASA Monographs, Nova York.

Holl, A.F.C. 1998. Livestock Husbandry, Pastoralisms, and Territoriality: The West African record. Journal of Anthropological Archaeology. 17, 143-165.

HYTSA Estudios y Proyectos S.A. 2012. Plan provincial de gestión integral de residuos sólidos urbanos (GIRSU) para la provincia de Catamarca, incluyendo planificación, estudios de factibilidad, diseños de ingeniería de detalle y elaboración de pliegos para la implementación de la GIRSU en la región prioritaria provincial. GIRSU MTLII-SBCC, Primer informe diagnóstico, Versión 2.

Ingold, T. 1988. Introduction. In: What is an animal? Unwin Hyman, Londres. 
2000. The perception of the environment. Essays on livelihood, dwelling and skill. Routledge, Nova York.

2011. Being Alive. Routledge, Nova York.

2012. Trazendo as coisas de volta à vida. Emaranhados criativos em um mundo de materiais. Horizontes Antropológicos. Vol.18, N³7.

Isla P. A. 2003. Los usos políticos de la memoria y la identidad. Estudios Atacameños. [online]. 2003, $\mathrm{N}^{\circ}$. 26, 35-44. Avaliable from: http://www.scielo.cl/.

Izeta, A.D. e Scattolin, M.C. 2006. Zooarqueología de una unidad doméstica formativa. El caso de Loma Alta (Catamarca, Argentina). Intersecciones en Antropología, UNCPBA, 7.

Jennbert, K. 2011. Animals and Humans: Recurrent symbiosis in archaeology and Old Norse Religion. Nordic Academic Press, Lund.

Jonhson, M. 2007. Ideas of Landscape. Oxford, Blackwell Publishing.

Jonzén, N., E. Knudsen, R.D Holt, B. Saether. 2011. Uncertainty and predictability: the niches of migrants and nomads. In: J.M. Fryxell e A.R.E. Sinclair (eds), Animal migration: A synthesis. Oxford University Press.

Kardulias, N. 2015. Introduction: Pastoralism as an Adaptive Strategy. In: N. Kardulias (ed), The ecology of pastoralism. University Press of Colorado.

Kelly, R.L. 1983. Hunter-Gatherer Mobility Strategies. Journal of Anthropological Research. Vol. 39, No 3, 277-306.

Kuznar, L.A. 2001. Introduction to Andean Ethnoarchaeology. In: L. Kuznar (ed), Ethnoarchaeology of Andean South America: contributions to archaeological method and theory. International Monographs in Prehistory, Michigan.

2001b. An introduction to Andean Religious Ethnoarchaeology: Preliminary results and future directions. In: L. Kuznar (ed), Ethnoarchaeology of Andean South America: contributions to archaeological method and theory. International Monographs in Prehistory, Michigan. 
Kuznar, L.A. and Sedhneyer, R. 2008. NOMAD: An Agent-Based Model (ABM) of Pastoralism-Agriculturalist Interaction. In H. Barnard and W.Z. Wendrich (eds), Archaeology of Mobility: Old World and New World Nomadism. Cotsen Institute of Archaeology, Los Angeles.

Kradin, N.N. 2015. The Ecology of Inner Asian Pastoral Nomadism. In: N. Kardulias (ed), The ecology of pastoralism. University Press of Colorado.

Layton, R. and Ucko, P.J. 1999. Introduction: gazing on the landscape and encountering the environment. In: P.J. Ucko e R. Layton (editors), The Archaeology and Anthropology of Landscape. Routledge, Londres e Nova York.

Leoni, J.B., J. Sartori, G. Fabron, A. Hernández e G. Scarafia. 2012. Aportes al conocimiento de las sociedades aldeanas del Período Temprano en la Quebrada de Humahuaca: una visión desde Antumpa. Intersecciones en Antropología, 13.

Leslie, P e McCabe, J.T. 2013. Response Diversity and Resilience in Social-Ecological Systems. Current Anthropology, Vol. 54, No 2.

Lynch, V. e Páez, M.C. 2011. Características de la relación local-estatal en el sitio Hualfín Inka (Depto. Belén, prov. De Catamarca, Argentina). Inferencias a partir del análisis cerámico. Arqueoweb 13.

Magadán, M. 1989. La arquitectura prehispánica del Noroeste Argentino: un cuadro de situación. Summa-Temátika 266-267.

Markakis, J. 2004. Pastoralism on the Margin. Minority Rights Groups International. Londres.

Marranghello, P.H., D. Merlo, M. Ramírez, R. Silva e D. Vinetz. 2000. Estudio de Impacto Ambiental. Capítulo 1. EIA-CAP 01-TX, [online], http://www.ucpypfe.gov.ar/PIVNG-1851/Cap1-SEstr.pdf.

Marín, J.C. B. Zapata, B.A. González, C. Bonacic, J.C. Wheeler e C. Casey. 2007. Sistemática tafonomía y domesticación de alpacas y llamas. Revista Chilena de Historia Natural, Vol. 80, N².

McCabe, J.T. 2004. Cattle Brings Us to Our Enemies. Turkana Ecology, Politics, and Raiding in a Disequilibrium System. University of Michigan Press, Ann Arbor. 
2005. El impacto y la respuesta a la sequía entre los pastores turkanas. Implicaciones para la teoría antropológica y la investigación de riesgos. Destacados [online], <http://www.redalyc.org/articulo.oa?id=13901903> ISSN 1607-050X

McGlade, J. 1999. Archaeology and the evolution of cultural landscapes: towards and interdisciplinary research agenda. In: P.J. Ucko e R. Layton (eds), The Archaeology and Anthropology of Landscape. Routledge, Londres e Nova York.

Mon, R. 1979. Esquema tectónico de los Andes del Norte Argentino. Revista de la Asociación Geológica Argentina. XXXIV (1).

Moran, E.F. 1991. Ecosystem Ecology in Biology and Anthropology: a critical assessment. In: The Ecosystem Approach in Anthropology: from concept to practice, E.F. Moran (ed). The University of Michigan Press, Ann Arbor.

Moritan, V.C., V. Canterelli, J. Nastri. 2015. El Carmen 1, un poblado intermedio tardío en el valle de Santa María (Prov. de Tucumán). Revista del Museo de Antropología, Vol. 8, Nº 1 .

Moritz, M., I.M. Hamilton, P. Schotte e Yu-Jen Chen. 2014. Ideal Free Distribution of Mobile Pastoralist in Multiple Seasonal Grazing Areas. Rangeland Ecol Manage, 67.

Morphy, H. 2015. Introduction. In: H. Morphy (ed), Animals into art. Routledge Library Editions: Archaeology, Nova York.

Mullin, D. 2011. Border Crossing: The Archaeology of Borders and Borderlands. An Introduction. In: D. Mullin (ed), Places in Between. The Archaeology of Social, Cultural and Geographical Borders and Borderlands. Oxbow Books, Oxford.

Murra, J.V. 1978. La organización Económica del Estado Inca. Siglo Veintiuno, México.

Murrieta, R.S., M.S. Bakin, C. Adams, P.S. de Souza Oliveira e R. Strumpf. 2008. Consumo alimentar e ecologia de populações ribeirinhas em dois ecossistemas amazônicos: um estudo comparativo. Revista de Nutrição, Vol. 21.

Nastri, J.H. 1997-8. Patrones de asentamiento prehispánicos tardíos en el sudoeste del Valle de Santa María (Noroeste Argentino). Relaciones XXII-XXIII. 
2001. La arquitectura aborigen de la piedra y la montaña (Noroeste Argentino siglos XI a XVII). Anales Museo de América, 9.

2008. La figura de las largas cejas de la iconografía santamariana. Chamanismo, sacrificio y cosmovisión calchaquí. Boletín del Museo Chileno de Arte Precolombino, Vol. 13, $\mathrm{N}^{\mathrm{o}} 1$.

Nastri, J. H.; Pratolongo, G.; Caruso, G.; Hopkzac, M. e Maniasiewicz, M. 2002. Los puestos prehispánicos de la sierra del Cajón. Actas del XIII Congreso Nacional de Arqueología Argentina, 421-430.

Neves, E. e Peterson, J. 2005. Political Economy and Pre-Columbian Landscape Transformation in Central Amazonia: In: W. Balée e C. Erickson (eds), Time and Complexity in Historical Ecology: Studies in the Neotropical Lowlands. Columbia University Press, Nova York.

Nielsen, A. E. 2001. Ethnoarchaeological perspectives on Caravan Trade in SouthCentral Andes. In: L. Kuznar (ed), Ethnoarchaeology of Andean South America: contributions to archaeological method and theory. International Monographs in Prehistory, Michigan.

2003. Ocupaciones prehispánicas de la etapa agropastoril en la laguna de Vilama (Jujuy, Argentina). CUADERNOS FHyCS-UNJu, № 20, 81-108.

2006. Resenha: Caravanas, Interacción y Cambios en el desierto de Atacama, José Berenguer Rodriguez (2004). Chungará (Arica). №1. Vol. 36.

Odell, G.H. 1994. Prehistoric hafting and mobility in the North American Midcontinent: Examples from Illinois. Journal of Anthropological Archaeology. Vol 13, pp. 5173.

Palermo, M.A. e Boixadós, R. 1991. Transformaciones en una comunidad desnaturalizada: Los Quilmes, del Valle Calchaquí a Buenos Aires. Anuario IEHS, $\mathrm{N}^{\circ} 6$.

Paoli, H. P. 2002. Recursos Hídricos de la Puna, Valles y Bolsones Áridos del Noroeste Argentino. Instituto Nacional de Tecnología Agropecuaria y Centro de Investigación, Educación $\quad$ y Desarrollo, [online], http://inta.gob.ar/sites/default/files/script-tmp-rhp.pdf 
Peréz Gollán, J.A. 2000. El jaguar en llamas (la región del antiguo Noroeste Argentino).

In: M. Tarragó e J. E. Burucúa (eds), Nueva Historia Argentina, Tomo 1. Editorial Sudamenricana.

Politis, G. 2002. Acerca de la etnoarqueología en América Del Sur. Horizontes Antropológicos. Ano 8. N 18. Pp 61-91.

1996. Nukak. Linotipa Bolívar y Cia. S. en C. Colombia.

2015. Reflections on contemporary ethnoarchaeology. Pyrenae, №46, Vol1.

Quesada-Embid, M.C. 2008. Dwelling, Walking, Serving: Organic preservation along the Camino de Santiago de Pilgrimage landscape. Ph.D. dissertation, Antioch University New England.

Reynoso, A.D. 2005. Arqueología en Catamarca. El Valle de Santa María de Yocavil: Arqueoastronomía en un poblado precolombino de Yocavil: La frontera del sol en Rincón Chico. Encrucijadas, N³1, UBA.

Rodriguez, L. 2008. Después de las Desnaturalizaciones. Reconfiguraciones socioeconómicas y étnicas al sur del valle Calchaquí. Santa María, fines del siglo XVIIfines del XVIII. Antropofagia, Buenos Aires.

Rosen, S.A. 2008. Desert Pastoral Nomadism in the Longue Durée: A Case Study from Neveg and the Southern Levatins Deserts. In H. Barnard and W.Z. Wendrich (eds), Archaeology of Mobility: Old World and New World Nomadism. Cotsen Institute of Archaeology, Los Angeles.

Ruiz, M. 1995-1996. Prehistoria y Arqueología Regional: El Noroeste Argentino. AnMurcia 11-12.

Salomon, F. 1985. The Dynamic Potential of the Complementarity Concept. In: S. Masuda, I. Shimada e C. Morris (eds), Andean Ecology and Civilization. University of Tokyo Press. Tóquio.

Sanz de Arechaga, L. R. 1948. La vida pastoril en la Sierra del Cajón. Actas XXVIII Congreso Internacional de Americanistas, París.

Scattolin, M.C. 2006. De las sociedades aldeanas a los curacazgos en el Noroeste Argentino. Boletín de Arqueología PUCP 10, Lima. 
Scattolin, M.C., M.F. Bugliani, L. Pereyra Domingorena, L.I. Cortés, M. Lazzari, A. Izeta, M. Darío y Calo. 2012. Habitar, circular, hacer: el punto de vista de La Quebrada. In: M. Alejandra Korstanje, M. Lazzari, M. Basile, F. Bugliani, V. Lema, L. Pereyra Domingorena, M. Quesada (eds), Crónicas materiales precolombinas. Arqueología de los primeros poblados del Noroeste Argentino, Sociedad Argentina de Antropología.

Shankland, D. 2012. Introduction: Archaeology and Anthropology: Divorce and Partial Reconciliation. D. Shankland (ed), Archaeology and Anthropology. Past, Present and Future. ASA Monographs, Nova York.

Sidky, H. 2015. Agropastoralism and Transhumance in Hunza. In: N. Kardulias (ed), The ecology of pastoralism. University Press of Colorado.

Silliman, S.W. 2009. Change and continuity, practice and memory. Native American persistence in colonial New England. American Antiquity, Vol. 74, No 2.

Silliman, S.W., Katherine H. e S. Ding. 2008. Working on Past for Future Eastern Pequot Field School Archaeology in Connecticut. In S. Silliman (ed), Collaboration on the Trowel's Edge: Teaching and Learning in Indigenous Archaeology. University of Arizona, Tucson.

2015. Reflections on Contemporary Ethnoarchaeology. Pyrenae. № 46, Vol. 1.

Silva, F.A. 2000. As Tecnologias e Seus Significados. Um estudo da cerâmica dos Asuriní do Xingu e da Cestaria dos Kayapó-Xikrin sob uma perspectiva Etnoarqueológica. Tese de Doutorado, MAE-USP.

2002. Mito e Arqueologia: A interpretação dos Asurini do Xingu sobre os vestígios arqueológicos encontrados no parque indígena Kuatinemu-Pará. Horizontes Antropológicos. Ano 8, N¹8, p.175-87.

2011. Etnoarqueologia: uma perspectiva arqueológica para o estudo da cultura material. Capa. Vol.8, №16, Pp. 121-139.

Smith, S. T. 2008. Crossing Boundaries Nomadic groups and ethnic identities. In: H. Barnard and W.Z. Wendrich (eds.), Archaeology of Mobility: Old World and New World Nomadism. Cotsen Institute of Archaeology, Los Angeles. 
Snead, J.E., C.L. Erickson, J.A. Darling. 2009. Making Human Space: The Archaeology of Trails, Paths, and Roads. In: J.E. Snead, C.L. Erickson e J.A. Darling (eds), Landscapes of movement: Trails, paths and roads in anthropological perspective. University of Pennsylvania Museum of Archaeology and Anthropology, Philadelphia.

Sylla, D. 1995. Pastoral organization for uncertain environment. In: I. Scoones (ed), Living with uncertainty. New directions in pastoral development in Africa. ITDG, Londres.

Swift, J. 1995. Dynamics ecological systems and the administration of pastoral development. In: I. Scoones (ed), Living with uncertainty. New directions in pastoral development in Africa. ITDG, Londres.

Tarragó, M.N. 2000. Chacras y pucarás. Desarrollos sociales tardíos. In: M. Tarragó e J. E. Burucúa (eds), Nueva Historia Argentina, Tomo 1. Editorial Sudamenricana. 2007. Ámbitos domésticos y de producción artesanal en el Noroeste argentino prehispánico. Intersecciones en Antropología, Vol. 8.

2011. Símbolos, ofrendas y bienes metálicos en la puna y quebrada de Humahuaca, Noroeste Argentino. In: Religion and Representation in the Development of Southern Andean Civilization: Tiwanaku, Wari and Transcultural Art of the SAIS. The Cotsen Institute of Archaeology, UCLA.

Tineo, A. 2004. Estudios Hidrogeológicos valle del río Santa María - Sector Catamarca. Proyecto: UTF/ARG/017/ARG. FAO [online], http://www.fao.org/fileadmin/user_upload/rlc/utf017arg/valles_calchaquies/07.p df

2005. Estudios Hidrogeológicos del río del valle de Santa María - Provincia de Catamarca. Instituto Superior de Correlación Geológica. Serie Correlación Geológica 20, Catamarca.

Tomka, S.A. 1992. Vicuñas and llamas: Parallels in Behavioral Ecology and Implications for the Domestication of Andean Camelids. Human Ecology, Vol. 20, No 4. 
Tomoeda, H. 1985. The Llama is my Chakra: Metaphor of Andean Pastoralism. In: Andean Ecology and Civilization. S. Masuda, I. Shimada e C. Morris (eds). University of Tokyo Press. Tóquio.

Treshow, M. 1970. Environment and Planet Response. McGraw-Hill, Nova York.

Tripcevich, N. e J.M. Capriles. 2016. Advances in Archaeology in Andean Pastoralism. In: J.M. Capriles e N. Tripcevich (eds), The Archaeology of Andean Pastoralism. University of New Mexico Press.

Ventura, B. e Belardi, J.B. 2001. When Clouds Cover the Woods: Ethnoarchaeology in the Yungas of Salta, Argentina. In: L. Kuznar (ed), Ethnoarchaeology of Andean South America: contributions to archaeological method and theory. International Monographs in Prehistory, Michigan.

Wendrich, W. e Barnard, H. 2008. The Archaeology of Mobility: Definitions and research approaches. In: H. Barnard and W.Z. Wendrich (eds.), Archaeology of Mobility: Old World and New World Nomadism. Cotsen Institute of Archaeology, Los Angeles.

Williams, V. 2003. Nuevos datos sobre la prehistoria local en la Quebrada e Tolombón. Pcia. de Salta. Argentina. Anales Nueva Epoca, 6, [online] https://gupea.ub.gu.se/bitstream/2077/3257/1/anales_6_williams.pdf

Whitridge, P. 2004. Landscapes, houses, bodies, things: "Place" and the archaeology of Inuit imaginaries. Journal of Archaeological Method and Theory, Vol. 11.

Wynveldt, F., B. Balesta e M.E. Iucci. 2013. El paisaje tardío del valle de Hualfín: una reconstrucción arqueológica desde los poblados protegidos. Comechingonia, Revista de Arqueología, Vol. 17, Nº 2.

Xiao, N., S. Cai, M. Moritz, R. Garabed, L.W. Pomeroy. 2015. Spatial and Temporal Characteristics of Pastoral Mobility in the Far North Region, Cameroon: Data Analysis and Modeling. PloS One, Vol. 10, № 7.

Yacobaccio, H.D., e Madero, C.M. 2001. Ethnoarchaeology of a pastoral settlement of the Andean Plateau: an investigation of archaeological scale. In: L. Kuznar (ed), Ethnoarchaeology of Andean South America: contributions to archaeological method and theory. International Monographs in Prehistory, Michigan. 
Yacobaccio, H.D., M.P. Cata, M.R. Morales, P. Sola, M.S. Alonso, M. Rosenbusch, C. Vazquez, C.T. Samec, B.I. Oxman and Caceres, M. 2011. El uso de cuevas por pastores andinos: El caso de Cueva Quispe (Susques, Puna de Jujuy). In: Arqueología de la Puna Argentina: Perspectivas actuales en el estudio de la diversidad y el cambio cultural. Archaeopress, Oxford.

Yacobaccio, H.D. e Vilá, B. 2013. La domesticación de los camelideos andinos como proceso de interacción humana y animal. Intersecciones en Antropología, 14.

Yamamoto, N. 1985. The ecological Complementarity of Agropastoralims: Some comments. In: Andean Ecology and Civilization. S. Masuda, I. Shimada e C. Morris (eds). University of Tokyo Press. Tóquio.

Yarrow, T. 2012. Not knowing as knowledge. Asymmetry between archaeology and anthropology. D. Garrow e T. Yarrow (eds), Archaeology and Anthropology. Understanding Similarities, Exploring Differences. Oxbow Books, Oxford.

Zedeño, M.N. 1997. Landscape, land use, and the history of territory formation: an example from the Puebloan Southwest. In: Journal of Archaeological Method and Theory, Vol. 4, No 1.

Zedeño, M.N. and Bowser, B.J. 2009. The archaeology of meaningful places. University of Utah Press, Sat Lake City.

Zedeño, M.N. K. Hollenback and C. Grinnell. 2009. From path to myth: journeys and the naturalization of territorial identity along the Missouri river. In: J.E. Snead, C.L. Erickson e J. A. Darling (eds), Landscapes of movement. Trails, paths and roads in anthropological perspectives. University of Pennsylvania Museum of Archaeology and Anthropology, Philadelphia.

Zeder, M.A. 2012. Pathways to animal domestication. In: P. Gepts, T.R. Famula, R.L. Bettinger (eds), Biodiversity in Agriculture: Domestication, Evolution and Sustainability. Cambridge University Press. 
